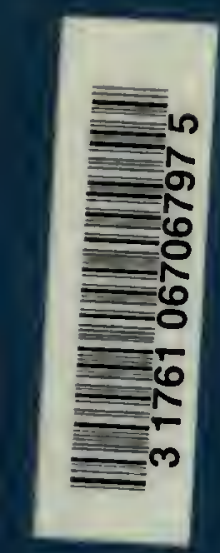








\section{Digitized by the Internet Archive in 2007 with funding from Microsoft Corporation .}


(32)

$I$

HOTRIN 

C L A S S I F I C A T I $0 \mathrm{~N}$

AND

\title{
GEOGRAPHICAL DISTRIBUTION
}

or

\section{R U S T A C E A:}

Frox

\author{
THE REPORT ON CRUSTACEA \\ OP TIIS \\ UNITED STATES EXPLORING EXPEDITION, UNDER \\ CAPTAIN CHARLES WILKES, U.S. N., \\ DURING THE YEARS $1838-1812$. \\ BT \\ JAMES D. DANA, A.M.,

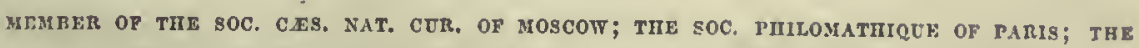 \\ OEOLOGICAL SOCLETY OF LONDON; THE AMERICAN ACA $\&$ OF ARTB AND SCIENCES \\ AT BOSTON; THE ACADEMT OF NATURAL SCIENCE, OF PHLADELPIT, ETC.
}

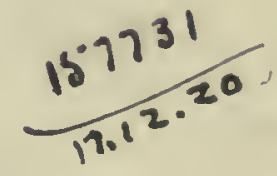

PHIL A D E I, PII I A :

PRINTED BY C. SHERMAN.

1853 . 



\title{
A REVIEW
}

\author{
OF THE CLASSIFICATION OF CRUSTACEA, WITH REFERENCE TO \\ CERTAIN PRLNCIPLES OF CLASSIFICATION.
}

THe class Crustacea exhibits a elearness of outline in its types, and a display of relations, transitions, and distinctions, among its several groups, exceeding any other department of the animal kingdom. This fact arises from the very great range in strueture oceupied by the speeies. The limits in size exeeed those of any other class, exclusive of the Radiata; the length varying from nearly two feet to a small fraetion of a line, the largest exeeeding the smallest lineally more than a thousand-fold. In the structure of the limbs, the diversity is most surprising, for even the jaws of one division may be the only legs of another; the number of pairs of legs may vary from fifty to one, or none. The antennse may be either simple organs of sense or organs of loeomotion and prehension; and the joints of the body may be widely various in number and form. In the branehial and the internal systems of structure, the variety is equally remarkable; for there may be large branchix, or none; a heart, or none; a system of distinet arterial vessels; or none; a pair of large liver glands, or but rudiments of them; a series of ganglions in the nervous cord, or but one ganglion for the whole body.

Taking even a single natural group, the Deeapods;-the abdomen may be very small, without appendages, and flexed beneath the broad cephalothorax out of view, or it may be far the larger part of the body, and furnished with several pairs of large natatory appendages; 
the inncr antennx may be very small, and retractile into fissures fitted to reccive them, or they may be very long organs, constantly thrown forward of the head; and descending but a single step, we come to species of Decapoda without proper branchix, some having the abdominal legs furnished witl branchial appendages, and others with no abdominal members at all.

When we consider, that these diversities occur in a class that may not embrace in all over ten thousand species (not half of which are now known), we then comprehend the wide diversity in the distinctions that exist. The series of species followed through, gives us an enlarged view of those distinctive characteristics upon which the limits and relations of groups depend. The network of affiliations, it is true, is like that in other departments; but it is more magnified to the view.

Moreover, the distinctions are obviously distinctions of rank. There is no ambiguity as to which is the higher or superior group, as among Insecta. The variations are manifestly variations in grade, and we may readily trace out the several steps of gradation, as we descend from the highest Brachyura to the lowest Lernæa. And while we so readily distinguish these gradations, we as plainly see that they are not steps of progress followed by nature in the production of species; but, simply successive levels (grades of types), upon which species have been multiplied.

We, therefore, may consider the class Crustacea as especially well adapted for instruction in some of the higher principles of classification in Zoology; and, if we mistake not, laws may be educed which have not hitherto taken form in science. These have already been partially alluded to in the previous pages of this volume. But we here bring together the facts in a connected view, in order to state the principles more definitely, and exhibit the full extent of their bearing. We leave out, lowever, a large part of the details, which may be found elsewhere in this Report.

The fundamental idea, which we shall find at the basis of the various distinctions of structure among the spccies is, the higher centralization of the superior grades, and the less concentrated central forces of the inferior, - a principle which has been applied to the animal kingdom in some of its larger subdivisions, but which has not bcen followed out into all the dctails of structure exemplified among Crustacea. 
This centralization is litcrally a cephatization of the forces. In the higher groups, the larger part of the wholc structurc is centred in the head, and contributes to head functions, that is, the functions of the senses and those of the mouth. As we descend, the head loses onc part after another, and with cvery loss of this kind, there is a step down in rank. This centralization may be looked for in the nervous cords; but the facts are less intclligibly studied there, than in the members, the production and position of which mcasure the condition of the forces:-just as we can better measurc the forces of a galvanic battery by the work donc, than by the sizc or external appcarance of the plates which constitute it.

In the Crustacea type, there arc normally twenty-one scgments, and correspondingly twenty-onc pairs of members, as laid down by Milne Edwards, the last seven of which pertain to thc abdomen, and the first fourteen to the cephalothorax. Now, we may gather from an examination of the crab, or Macroural Decapod, acknowledged to be first in rank, what condition of the, system is connected with the highest centralization in Crustacea.

In these highest species, nine segments and nine pairs of appcndages out of the fourteen cephalothoracic, bclong to the senses and mouth, and only five pairs arc for locomotion. Of these nine, thrce are organs of senscs, six are the mandibles and maxillæ. Morcover, these organs are clustered into the smallest possible space, so that the six pairs of mouth organs hardly occupy more room than the first pair of legs. The organs are all small, the antcnnæe excecdingly short, the maxillæo small lamellar organs sparingly jointed. The vegctative powcrs of growth have had but little play. The inner antcnnæe are rather large as regards the basal joint, which is devoted to onc of the senses, but the rcst is ncarly rudimentary, and the whole is snugly boxed away, to be extruded at the will of the animal. The exterior maxillw (or outer maxillipeds) cover exactly the other pairs, and slut closely down over the mouth, like a wcll-fitting operculum to the buccal arca.

We honce learn, that the condition of highest centralization in Crustacea, is whcre the cephalic part embraces the largest portion of the normal structure of the cephalothorax, and the whole is contracted within the smallest compass, with the lcast vegetative growth or elongation of the parts. The forces are concentrated in the morc perfectly developed scnses and the higher functions of the animalnot in giving size to the organs of the scnses, but acuteness to the 
sensorial function. The perfection of the scnses is evinced by the small antennæ; for we infer therefrom, not only that the organ is exclusively an organ of scnse, but also, that the dclicacy of the sense itsclf is such, as not to require a long-jointed appendage to aid the function.

This cephatization of the animal is farther observed in the structure of the rest of the thorax and the abdomen. The abdomen, in the first place, is reduced to its minimum size. Vegetative elongation is here cut slort, as in the anterior part of the animal; and the sphere of growth has a narrow limit, owing to the very intensity of its concentration; and we find that the limit widens as the intensity diminishes.

Again : the central power is indicated by the fact, that the first pair of legs is the strong pair; being properly liands, they contribute especially to the higher functions, that is, the support of the living animal, through their strength and powers of prehension, and not like the following, to locomotion. Thus, as we pass from the centre, the organs are of more and more bumble function.

This centre, as we have observed in another place, is properly between the second antennæe and mandibles. The sccond antennæ and the rudimentary mouth, are among the first parts that appear in the embryo. If we look at it as a centre of force or of growth, we remark that the radii on opposite sides of this centre, before and behind, are very unequal, the latter being six or eight times as long as the former, -a relation which is the inverse of the functional importance of the parts pertaining to each.

Our idea of the condition of highest centralization is thus drawn from a study of the species.

The most perfect state of it is seen in the Maia group, in which the bases of the antenno and eyes are crowded into the narrowest possible compass, and the mouth organs are well compacted within the buccal area, and the legs and whole system have the highest completencss.

The form of the body of a Maia is a somewhat flattencd ovoid, narrowest in front; and the middle point between the mouth and the second antennx, which we call the potential centrc of the animal, is situated near the front, say about half an inch from the front outline (excluding the beak), supposing the cephalothorax three inches long. We may call the part anterior to this centre, $A$; the part posterior, $B$; and the length of the former, measured on the axis, $a$; of the latter, $b$. These parts may be viewed, as regards development, as 
potentially equal; and yet the anterior, $\mathrm{A}$, is six times shorter and as much narrower and lower than the following. It would not, therefore, be far out of the way to say, in mathematical language, that the functional importance of the two parts varies inversely as the cubic contents of the parts.

We pass now to the degradations from this, the highest type.

These degradations are seen-

First, in a widening of the space between the antennæ.

Second, in a slight enlargement of the outer maxillipeds, so that they do not fit snugly over the buccal area.

Third, in an elongation of the antennæ.

Thesc are all cvidences of a slight relaxing of the concentrating element. The first, marks the transition of the Maia group to the Parthenopidx, and thence to the Cancridx. The second, carrics the grade a step lower, to species of the old genus Cancer, also to the swimming crabs and the Corystoids; and the third, marks off the Corystoids as the lowest of the true Brachyura.

While there are such marks of degradation exhibitcd through the growth or elongation of parts, there is also a mark, equally significant, in the obsolescence of the posterior thoracic legs, a peculiarity of many Grapsoids. In the Maioids, the species are wcll balanced; the type is perfect in its devclopment: the sustaining of the ccntral functions allows of the full and complete growth of all the other parts. But the diminution of force may not only be attended with a loosening of the cephalic hold on the remoter of the cephalic organs, but also, in a failure in the production of the postcrior organs of the body, or those on the outer limits of the system : and this is what happens in many Grapsoids. The swimming form of the legs in Lupa and allied species is a similar mark of inferiority.

Besides the above evidences of degradation, there arc still others in the Brachyural structure, which act conjointly with the preceding, producing lower grades of species. They are all marks of a rclaxation of the centralization.

Fourth. An enlargement or widening of the sternum and abdomen.

Fifth. The abdomen becoming somewhat relaxed from the venter instcad of remaining close-appressed to it.

Sixth. The vulvæ becoming more remote from one another, being situated in the bases of the third pair of legs, instead of the sternum. 
Seventh. The inner antennæ losing thcir fosscttes, and being constantly exsert.

Eighth. The branchix being more than nine in number on either side.

The first of these peculiaritics distinguishes many of the Grapsoids, as well as lower species. The second is observed in the Corystoids, and is an additional mark of their inferior grade. The third occurs in Dromia and allied. The fourth, in Latreillia. The fifth, in Dromia. Dromia and Latreillia have the posterior legs abbreviated, and in Dromia, this evidence of degradation is still stronger, in that the fourth as well as fifth pair is short and dorsal:

The last three characteristics, above mentioned, mark a transition towards the Macroural type, and the genera of this kind belong with the Anomoura. This transition is seen further in-

Ninth. The eyes being without fossettes.

Tenth. The second pair of antenna becoming exterior to the cyes.

Eleventh. The outer maxillipeds more enlarged and subpediform.

Twelfth. The abdomen more lax and furnished with a pair of caudal appendages.

Thirteenth. The abdomen more elongated, and hardly inflexed.

These several changes exhibit a continuation of the prosess of relaxation in the central forces. There is thereby an enlargement of the antennæe, and their more remote position at the anterior extremity of the animal; and also, an enlargement of the posterior or abdominal parts of the animal, and a development of appendages in the posterior direction. These marks of degradation, cxcepting the thirteenth, are found in the Hippa and Porcellana groups, and the thirteenth in the Paguridca. At the samc time that thesc Macroural characteristics appear, the body becomes elongated. The species all bear a stamp of imperfection in the abbreviated posterior lcgs, as explained above, as well as in the other points alluded to. The subordination of the nine anterior annuli to cephalic functions, which is so striking in the Maioids, has become less and less complcte, and the organs less perfect; moreover, the habits of the animals are more sluggish, and they are less fitted for self-preservation. The large Dromia picks up a waste shell, and by means of its hind legs, lifts it over its body for protection, and the Pagurus finds sheltcr in tlic water-worn univalves of a coast. 
The degradation pointed out, is hence, not merely a variation in the position and size of certain organs, but an actual deterioration in rank and intelligence.

Other minor points exhibiting difference of grade, might be mentioned: but they have already been subjects of remark. We state here only one-the cliaracter of the fingers of the large hands. In the higher species, these fingers are pointed; in a grade below, in some groups, they lave a spoon-like extremity. This excavate form is often more perfect in young individuals than in adults, which is one evidence that it is in fict proof of inferiority. By this mark we learn that the Chlorodinae are of lower grade than the Xanthinos; the Paguri, than the Bernhardi; the Mithracida, than the Maiada, etc.

luct us pass now to the Macroura. In the typical Macroural species, the antennæ, instead of being minute, with the inner retractile, are long exsert organs, and the outer have a large plate as an appendage at base; the eyes are without sockets; the outer maxillipeds are pediform, and do not closely cover the other mouth organs; the abdomen is often longer than the rest of the body, and las its six regular pairs of appendages. All these points show a still further relaxing of the centralization or cephalization of the species. There is an elongation of the parts anterior to the mouth, and also of those posterior, and this elongation of the two extremities is approximately proportional to the relative dimensions of the corresponding parts in the Bracliyura. If we were to draw out an ovoid with the relative length and breadth of a Macroural cephalothorax, and place its focus so as to correspond with the position of the posterior margin of the epistome, in a manner like that proposed for the Maia among Brachyura, the ovoid would be very narrow, and the focus or centre proportionally farther from the front than in the Brachyura.

In following down the degradation of the Brachyura to the Anomoura, we have found the posterior legs becoming abbreviated, and the whole structure in its aspect imperfect. But, in the typical Macroura, there is nothing of this seeming impcrfection. The legs are all fully formed; the animals are exceedingly quick in their motion, instead of being sluggish; and every organ is apparently in its most perfect state for the uses of the system to which it is tributary. We sliould, therefore, understand, that the process of degradation, alluded to above, is not one actually passed through in the system of creation; 
for by its progress we should never reach the Macroural structure; nor, in the reverse order, should we from the Maeroural reaeh the Brachyural structure. In the remarks above, we speak only of the comparntive aetual conditions of the specics as regards centralization.

The Macroura and Brachyura bclong to subordinate, yet eorrelated types of strueture, each perfect in itself, and admitting of wide modifications, and having its own system of degradations. We add a few words on these degradations among the Macroura. We have seen that, in the Brachyura, the powerful prehensile legs arc those of the first pair, these acting for the eollection of food, and so contributing to the mouth. In the Macroura, there are species of high rank that have the anterior legs strong-handed, like the Macroura. There are others, in which the second or third pair is the strong-handed pair; others having all the legs weak appendages, with only rudimentary hands or none. The several marks of degradation are as follows:-

First. The outer maxillipeds pediform.

Second. The maxillipeds next anterior pediform.

Thircl. Sceond pair of legs ehcliform and stouter than the first.

Fourth. The third pair of legs cheliform and stouter than either of the preceding.

Thus as we descend, we find one and even two pairs of mouth appendages beginning to pass from the mouth seties to the foot scrics, and the eephalic portion is thus losing its appendages and high centralized eliaraeter. Moreover, the power belonging to the first pair of legs in

( the higher spccies is transferred to the seeond pair of legs, as in the : Palamons; or, to the third pair, as in the Penæidæ; indieating a further decrease of that centralization so remarkable in the Brachyura. Still lower among the species, as in the Sergestidø, all the legs arc weak, and the postcrior pair may be short or obsolete,-the samc deterioration that oecurs in the lower Brachyura.

As we descend farther, there is an inereased obsolesccnee of organs, and every step is onc of marked imperfection as well as degradation.

Fifth. The branehiso become external and small.

Sixth. The branehix become wholly wanting, or part of the abdominal appendages.

Seventh. The last two pairs of thoraeie legs becomc obsolete.

Eighth. The abdominal appendages become obsolete. 
Ninth. The eyes and antennæe have separate segments, and the abdomen is very long and large.

The fifth point of degradation is seen in the Eupliausidor; the sixth, in the Mysidoe and other Anomobrancliates; the seventh is found in several genera of the same group; the eighth in certain Mysidx. The Anomobranchiates are thus degraded Macroura. There is not merely a relaxing of the centralization; but the forces are so weakened as not to succeed in finishing out the members in the system of structure to which they pertain. The species consequently are not modifications upon the level of the Macroural type, nor upon a distinct level or distinct type; but simply imperfcet developments of the Macroural structure below the true level of that type. They bear nearly the same relation to the Macroura, that the Anomoura bear to the Brachyura. The ninth step is seen in the Squilloidea, whose relaxation of system and elongation in the cephalic part, as well as abdomen are remarkable.

The continuation of the line of degradation represented in the Anomoura, is not to be found, as we have remarked, amolig the typical Macroura. But the structure of the Paguri may be traced into the aberrant Macroura, called Thatassinidea; and thence, both in the abdomen, the lcgs, and the branchix, we observe a transition to the Squilloids, one division of the Anomobranchiates. If then, we were to tracc out the lines of affinity in the species, it would be from the Mysis group to the typical Macroura, and from the Squilla group to the Thalassinidea, as elsewhere explaincd. From the latter, the lines lead mainly to the Anomoura and higher species.

In our revicw, thus far, we recognise one only of the primary types of structure among Crustacca. This primary type is characterized by liaving nine normal annuli or segments devoted to the senses and mouth, that is, to the cephalic portion of the body. It includes two, or, we perhaps may say, three secondary types. The first of these secondary types is the Brachyural; it has the antenna small, the inner pair in fossettes, the abdomen without appendages. In the other type (or other two, if so considered), the antennæ are elongated, and botl pairs free, the abdomen is elongated, and furnished with a series of appendages. This, the sccond type, is the Macroural; or, if we assume that it embraces two distinct types (a sccond and third), the two correspond to the typical Macroura and the Thalassinidea. 
Each secondary type embraces types of more subordinate character, which it is unnecessary lere to dwell upon.

There is a tendency in the lowest species to a transfer of the two postcrior mouth appendages to the foot series, so as to leave but seven cephalic annuli; but it is only a modification of the primary type, as the species have every mark of being degraded or imperfect forms, and are not examples of a new type.

In this primary type, the spccies vary in length from half an inch to twenty inches. Two inches may be set down as the average length and breadth for the Brachyura; while threc inches is the average length of the Macroura, the average breadth being half an inch or less.

The second primary type among Crustacen is as well defined in its limits, and as distinct in its characters as the first. Instcad of having nine annuli devoted to the senscs and mouth, there are but seven, the mouth, including a pair of mandibles, two pairs of maxilla, and one of maxillipeds. The number is permanent and cliaracteristic. There are, conscquently, seven pairs of legs in these species, instead of five, the Decapod number; and the specics have been appropriately styled the Tetradecapoda. Instead of exhibiting any appearance of imperfection, or any obsolescent organs, like those lower Macroura that show a transition to a fourteen-footed structure, the organs are all complete, and the whole structure is pcrfect in synimetry and unique in character. They have not a Macroural characteristic. The eyes are not pediccllatc; there is no carapax, but a body divided into as many segments as therc are legs (whence our name Choristopoda); the antennæ, legs, and whole intcrnal structure are distinct in type. The branchio are simple sacs, either thoracic or abdominal.

We have, therefore, in the Tetradecapods an expression of that structure of body, and that size, which belongs to a system, in which but seven annuli or segments are concentrated in the cephalic portion of the structure. The structure is far infcrior to the Decapodan. The size rarely exceeds two inches, though in extreme cases three to four inches; and probably half an inch is the average length. The contrast between the first and second of the primary types, is therefore as distinct in the average size of their structures, as in their actual grade or rank.

Supcrior rank among the Tetradccapods may be distinguished by some of the same points as in the Decapods. The short antenne, 
short compact bodics, and abbreviated abdomen of the Isopods, are proofs of their supcriority of gradc. The abdominal appendages are simply branchial, and in the higher specics are naked or non-ciliated lamclla. The transitions to a lower gradc are scen in the elongation of thesc abdominal lamella, thcir becoining ciliated, and the abdomen being also more clongated and flcxible; then in the abdominal lamellæ becoming elongated natatory appendages, and the abdomen taking a length usually not less than that of the thorax, as in the Amphipods, in which the branchix are appendages to the thoracic legs. And whilc this elongation goes on posteriorly, there is also anteriorly an enlargement of the antennx, which in the Amphipoda are usually long organs. There are thus two secondary types of structure among the Tctradccapods, as among the Dccapods; a transition group betwcen, analogous to the Anomoura, partakes of some of the characters of both types, without being a distinct type itself. Thesc are our Anisopoda. The species graduate from the Isopod degree of perfection to the Bopyri, the lowest of the Tetradccapods. There is thus another analogy betwecn this group and the Anomoura.

The Trilobita probably belong with the second typc, rather than the third. Yet they show an abcrrant character in two important points. First, the segments of the body multiplicd much beyond the normal number, as in the Phyllopoda among the Entomostraca; and Agassiz has remarked upon this as cvidence of that larval analogy which claracterizes in many cases the carlicr forms of animal life. In the second placc, the size of the body far transcends the ordinary Isopodan limit. This might be considered a nuark of supcriority; but it is niore probably the reverse. It is an cnlargement beyond the normal and most cffective size, duc to the same principlc of vegetative growth, which accords with the inordinate multiplication of scgments in the body.:

The third primary type (the Entomostracan) includes a mucl wider variety of structure than cither of the preceding, and is less persistent

* Prof. Guyot very bappily names the three great periods of geologieal bistory-usually denominated the Palacozoic, Secondary, and Tertiary, or, by Agassiz, the age of Fishes, that of Reptiles, and that of Mammals, - the Vegetative, the Motorial, and the Sensorial epoehs;-the first, being the period charaeterized prominently by regetative growth in animal life; the sceond, by the inercased development of the muscular system, as exemplified by the enormous reptiles of the epoeh; the third, by the derelopment of the higher functions of the brain, exhibited in the appearanec of mammals. 
in its characteristics. It is, however, more remote in habit from the Tetradecapods, than from the lowest Decapods, and is properly a distinet group. Unlike the Deeapods and Tetradeeapods, there are normally but six annuli devoted to the senses and mouth in the highest of the speeies, and but five in others, the mouth ineluding a pair of mandibles, and either one or two pairs of maxillw (or maxillipeds). This is an abrupt step below the Tetradecapods. We exclude from these mouth organs the prehensile legs, ealled maxillipeds by some authors, as they are not more entitled to the name than the prehensile legs in Tanais, and many other Tetradeeapods. There is an exception to the general prineiple in a few species. A genus of Cyproids has three pairs of maxillæ; but this may be viewed as an example of the variations whiel the type admits of, rather than as an essential feature of it,-possibly a result of the process of obsoleseence whieh marks a low grade, as in the Mysidæ, whose abdomen by losing its appendages, approximates in this respeet to the Brachyural structure, though, in faet, far enough remote.

The species of the Entomostraean type show their inferiority to either of the preecding in the absenee of a series of abdominal appendages, and also in having the appendages of the eighth, ninth, tenth, and eleventh normal rings, when present, natatory in form.

The range of size is very great,-and this is a mark of their low grade, for in this respect they approaeh the Radiata, whose limits of size are remarkably wide. Nearly all of the species, and those whieh, by their aetivity, show that they possess the typieal structure in its highest perfeetion, are minute, not averaging over a line in length, or perhaps more nearly three-fourths of a line.

Taking this as the true expression of the mean normal size of the type, the three primary types will vary in this respect as 24 (two inehes) $: 6: 1$.

The size in this third type, reaches its maximum in the Limuli; and these are unwieldy speeies, whose very habits show that vegetative growth has given them a body beyond the sueessful eontrol of its weak system, that is, a larger frame than it has power to wield with eonvenienee or defend, for it is at the merey even of the waves upon a benel.

This type has its highest representatives among the Cyelopoids, whieh remind us of the Mysis group of the higher Crustacen. In these, the eephalic part ineludes six out of the fourteen eephalotho- 
raeic annuli. In the Daphnioids and the Caligoids, they inelude only five. In Limulus, only the first four can properly be eounted as of the cephalie series. In many other Entomostraea, the mouth organs are nearly as perfect legs as in Limulus, and the speeies, although evidently of a low grade, cannot properly be removed from the group Limulus has its ncarest ally in Apus, although this genus has the mouth organs of a Daphnia.

The lowcst species of the type are the Lernæoids.

A fourth primary type includes the Cirripeds. It is of the same rank as regards cephalization as the Entomostraea; yet, it has so many peeuliarities of structure, that it slould be regarded as a distinet type, rather than a subordinate division of the third type.

The mean size of the species of this group is much greater than the same among the lighler Entomostraea. But if we regard the young in its active Cypris state, and compare it with the eorresponding condition of species of Cyproids, we shall discover that the species have, in fact, an abnormal growth; a growth which takes plaee at the expense of the powers of motion or action in the individuals. The body, when it eommences a sedentary life, inercases in magnitude far beyond the Cypris or Daphnia size; and there is a eorresponding loss of power. The same force will not move a heavy structure, that is sufficient for the tiny model; and when the model is enlarged without a eorresponding increase in the seat of power, sluggish motion is the necessary consequenee. Thus it is with the Medusx. Individuals of the minuter species, or the larger species, when in the young state, are gifted with active powers of motion; the strueture conforms to the forces within: but as the species enlarge, they beeome slow in movement, or lose almost every attribute of life! The same prineiple is illustrated again in the Bopyri. The male is a small active animal, related to Jæra and Tanais. The female, of sedentary habits, becomes grossly enlarged and corpulent, so as to exeeed by twenty-fold lineally the length of the male, and nearly ten thousand times its bulk. It is manifest, that the nervous system, or motive power of the female, is absolutely no greater than that of the male; and consequently, the eapabilities of locomotion will be ten thousand times less, or the female will move but a ten-thousandth of an inch at the most, while the male is moving one incl, a faet with regard to them, as any one is aware of who has seen the ineapability of the female to make any 
progress by locomotion. This then, is an example beyond dispute, of a system overgrown through the vegetative process, so as to be too much for the motive energies within. The Lernæoids afford a similar illustration of this principle.

For the same reason, therefore, as in the Bopyri, the Medusx, the Lernæoids, and the Limuli, we cannot compare the actual mean size of the adult Cirripeds with those of the other primary types. We should rather infer the mean normal size for such a conparison, from the size of the young before it becomes sedentary, or from that of free males, if such exist. Such males are announced by Darwin, as actually occurring in some species. Moreover, they are very minute, varying from a line to half a line or less in leugth. This, therefore, is some reason for taking as the mean normal size, the same as given for the Entomostraca.

A fifth primary type includes the RotatoRIa. In these animalcular species, the mouth includes a pair of mandibles and often a rudimentary pair of maxilla; and consequently, the cephalic portion may contain the same number of annuli as in the Daphnia group, with which group many of them have near relations. They have usually an articulated abdomen, furcate at extremity, like the Cyclopoids. The grand point of inferiority to the Entomostraca, evincing the more infinitesimal character of the system of life. witlin, is the absence of all thoracic appendages or legs. The organs of locomotion are simply cilise arranged about the head; and it is quite probable that two sets (or more) of them correspond to the second pair of antennx, as these are organs of prehension and motion in inany Entomostraca. In Callidina, there are two sets, some distance from the extremity of the liead, which may have this relation; and the two sets in the true Rotifers may also be of this character. In others, the corresponding parts are actually somewhat elougated.

The species vary in size from a line to a sixtieth of a line. Probably one-ninth of a line is the average size.

The actual relation of the Rotatoria to the Entomostraca (which view the author sustained in his Report on Zoophytes (1845)), can hardly be doubted by those who have the requisite knowledge of the lower Crustacea for comparison. The structure of the body, the jointing and form of the abdomen, when it exists, the mandibles, and alimentary system, the eyes when present,-all are Crustacean; and 
a slight transformation of some Entomostraca-an obliteration of the legs and substitution of locomotive ciliæ-would almost turn them into Rotatoria.

In the classification which has been developed, we have made out five primary types of structure among Crustacea. A grand distinction has been shown to consist in the different degrees of cephalization of the normal Crustacean structure. The consecration of nine annuli, out of the fourteen cephalothoracic, to the senses and mouth, distinguishes the highest type; of seven, the second type; of six or five, the third and fourth; of five or four, the fifth. In connexion with other distinctions in these types, we find that they correspond to structures of different size, the size being directly related to the grade. These particulars may be tabulated as follows :-

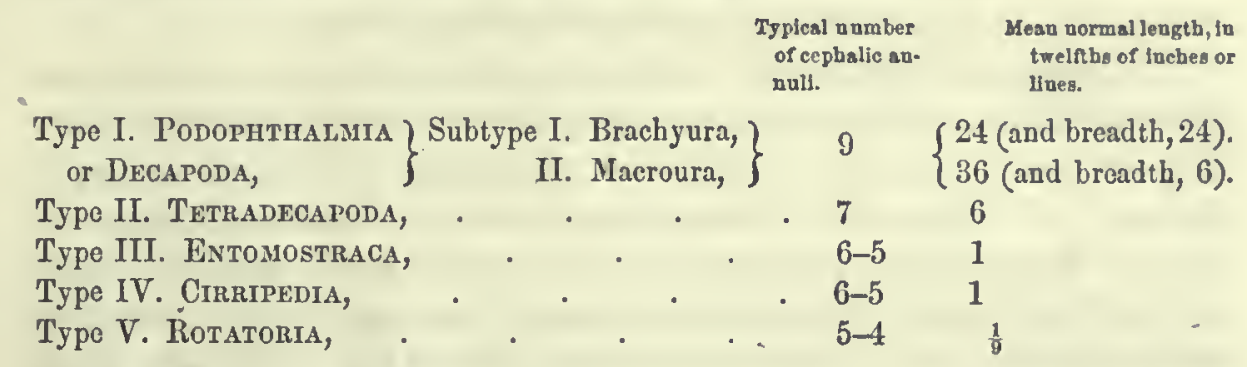

The first type is alone in having true thoracic branchix, and pedicellate eyes.

The second type has branchial sac-like appendages, either abdominal or thoracic, and sessile eyes.

The third type has generally no branchiæ, the surface of some part or all of the body serving for aeration. A few species, however, are furnished with special organs for this function. This is, however, no mark of superiority in such species, for they occur even in the Limuli, among the lowest of the Entomostraca. The necessity of them in this case arises from the abnormal size of the species, both the mark and occasion of its inferiority; for the system is thus too large for the mode of surface aeration, found among ordinary Entomostraca; moreover, the shell, which so large an animal possesses and requires for the attachment of its muscles and its movements, is thick and firm, and this is inconsistent with aeration by the exterior surface of the body. The same remarks apply to the liver glands, which are very small or wanting in the small species. 
The third and fourth types show thcir inferiority to the second, by the abscnce of a series of abdominal appendages; and the fifth a lower state still, in the absenee of both thoraeic and abdominal legs. The more degraded Macroura (certain Mysidx) show a transition in this obsolescence of abdominal organs to the third type.

Some of the conclusions from these faets are the following.

I. Each type corresponds to a eertain system of force, more or less centralized in the organism, and is an expression of that force,- - the higher degree bcing such as is fitted for the higher struetures developed, the lowcr sueh as is fitted for structures of inferior grade and size. In other words, the life-system is of different orders for the different types, and the structures formed exhibit the extent of their spheres of action, being such as are adapted. to use the force most effeetively, in aecordanee with the end of the speeies.

II. In a given typc, as the first, for example, the same system may be of different dimensions, adapted to structures of different sizes. But the size in either direction for structures of efficient aetion is limited. To pass these limits, a life-system of another order is required. The Macroura, as they diminish in size, finally pass this limit, and the organisms (Mysidæ, for examplc) are no longer perfect in thcir members; an obsoleseence of some parts begins to take place, and speeies of this small size are actually eomplete only when provided with the strueture of a Tetradecapod.

The extreme size of strueture admitting of the highest effieient aetivity is gencrally three to six times lineally the average or mean typical size. Of these gigantie species, three or four times longer than the mean type, there are examples among the Braehyura and Maeroura, whieh have all the highest attributes of the speeies. There are also Amphipoda and Isopoda three inehes in length, with full vigorous powers. Among Entomostraea, the Calanidx, apparently the highest group, inelude species that are three lines long, or three times the length of the mean type.

III. But the limit of efficient activity may be passed; and when so it is attended with a loss of aetive powers. The structure, as in the female Bopyrus and Lernxoids, and the Cirripeds, outgrows vegetatively the proper sphere of action of the system of force within. This result is espeeially found in sedentary species, as we have exemplificd in our remarks on the Cirripeds. 
IV. Size is, therefore, an important element in the system of animal structures. As size diminishes, in all departments of animal life, the structure changes. To the human structure there is a limit; to the quadruped also, beyond wlich the structure is an impossibility; and so seems the case anong Crustacca. The Decapod, as the size diminishes, reaches the lowest limit; and then, to continue the range of size in species, another structure, the Tetradecapodan, is instituted; and as this last has also its limit, the Entomostracan is introduced to continue the gradation; and, as tliese end, the Rotatoria begin. Thus Crustacea are made to embrace specics, from a lengtl of nearly two feet (or two hundred and fifty lines) to that of a one-hundred-and-fiftieth of a line. These sevcral types of structure among Crustacea do not graduate, as regards size, directly from one to another, but they constitute overlapping lines, as has bcen sufficiently shown.

$\mathrm{V}$. In the opposite extreme of organic beings, the vegetable kingdom, the same principle is illustrated. Plants may be so minute as to have free motion and activity, as in animals. The sporcs of certain Algæe are known to have powers of locomotion, and some so-called Infusoria, are now admitted to bclong to the vegetable kingdom. These are examples of locomotive plants. Now, ordinary plants, like Cirripeds, are examples of sedentary species, that have outgrown the limits of activity. The life-system of a plant, is in fact sufficient in power to givc locomotion only to the minute plant-individuals alluded to; and infusorial species of plants retain it, as long as they live. But when, as in the Alga, vegetative growth procceds in the enlargement of the minute infusorial spore, it immediatcly outgrows its activity, and becomes a sedentary plant. In most other plants, the seed have never the minute size which admits of motion.

The mean size of the Entomostracan type was stated to be one line; of the Rotatorial type, one-sixth of a line; and we may'add, that the mean size of the plant type-understanding by this, as in other cases, the mean size admitting of thc highest activity-if deduced from the size of plant-infusoria, would be about one-sixtietl of a line.

We observe, that the smallest size of the perfect Macroura (first type) is very nearly the mean size as to length of the animals of the second type. So also, the smallest size of the perfect animal of the second type (Tetradecapoda) is very nearly the mean size of the most perfect animals of the third type; and the smallest size of tlic perfect animal of the third type is nearly the largest sizc in the fifth type. 
In order to compare allied animals of different sizes, it should be noted, that while there is some foundation for the conclusion, that under certain limitations, sizc is a mark of grade, rapidity of movement or action should also be considered; and the more proper comparison would be between multiples of size and activity. This deduction, is, however, true only in the most gencral sense, and rather between species of allied groups than those of different types. We may occasionally find something like an exemplification of the law among bipeds, ludicrous though the idea may be.

VI. We observe with regard to the passage in Crustacea to inferior grades under a given type, that there are two methods by which it takes place.

1. A diminution of centralization, lcading to an enlargement of the circumference or sphere of growth at the expense of concentration, as in the elongation of the antenna and a transfer of the maxillipeds to the foot series, the elongation of the abdomen and abdominal appendages, etc.

2. A diminution of force as compared with the size of the structure, leading to an abbreviation or obsolescence of some circumferential organs, as the posterior thoracic legs or anterior antenna, or the abdominal appendages (where such appendages exist in the sccondary type .embracing the species). Thesc circumstances, moreover, arc independent of a degradation of intclligence, by an extension of the sphere of growth beyond the proper limits of the spliere of activity.

VII. A classification by grades, analogous to that deduced for Crustacea, may no doubt be laid out for other classes of animals. But the particular facts in the class under consideration, are not to be forced upon otlier classes. Thus, while inferiority annong Crustacea is connected with a diminished number of annuli cephalically absorbed (for the senses and mouth), it by no means follows, that the Insecta, which agree in the number of ccphalic annuli with the lower Crustacea, are allied to them in rank, or inferior to the higher specics. On the contrary, as the Insecta pertain to a distinct division, being aerial instead of aqueous animals, they can be studied and judged of, only on principles deduced from comparison among insects themselves. They are not subject to Crustacean laws, although they must exernplify beyond doubt, the fundamental idea at the basis of those laws.

The views which have been explained, lead us to a modification, in some points, of the classification of Crustacea, adopted in the early 
part of this Report, and followed out through the subsequent pages. The question, whether the eyes are pedicellate or not, upon which the names Podophthalmia and Edriophthalmia are based, proves to be one of secondary importance. And although still available in distinguishing almost infallibly the species of the first type, it is far from rendering it necessary or natural to embrace togetler under a common division the species that have sessile eyes (so-called Edriophthalmia), as done by most writers on this subject.

The term Decapoda, in view of these principles, has a higher signification than has been suspected, since by expressing the number of feet, it implies the number of cephalic annuli characterizing the species. It would not be employing it inconveniently, therefore, if it were extended to embrace all the Podophthalmia, or all species of the first type, including the Mysis and Squilla groups.

For a like reason, the term Tetradecapoda has a high significance, as applied to the species of the second type. The position of the Trilobita still remains in doubt. The Cirripedia and Entomostraca, third and fourth types, stand properly on nearly the same level.

On the following pages, we offer a review of the classification of Crustacea, with the characters of the several subdivisions.* We first present the characters of the higher divisions of the class, that is

The Subclasses, Orders, and Tribes of Crustacea.

* References and synonymy are omitted beyond, as they have been giren fully in other parts of the work. 


\section{CR USTACEA.}

SÜbclassis I. PODOPHTHALMIA (VEL DECAPODA).

Annuli cephalothoracis cephalici (ad sensus et appendices buccales pertinentes) numero novem. Oculi pedunculati. Branchiæ aut foliosæ aut filosæ, sub thoracis lateribus dispositæ, raro obsoletæ vel abdominales. Cephalothorax carapace plus minusve tectæ.

ORdo I: EUBRANCHIATA:.

Branchiæ apud thoracis latera dispositæ, carapace tectæ.

Tribus I. BRACHYURA.-Corpus latum. Abdomen in sternum inflexum et stricte appressum, appendicibus carens. Branchiæ utrinque numero novem. Vulvæ in sternum excavatæ. Carapax suturâ longitudinali infra utrinque notatus, antice cum epistomate coalitus.

Tribus II. ANOMOURA:-Corpus sive latum sive multum elongatum. Abdomen sæpe ac in Brachyuris, sæpe ad sternum laxe appressum, interdum elongatum, et non inflexum, et appendicibus caudalibus instructum raro appendicibus aliis. Branchiæ utrinque numero novem vel plures. Vulva in pedum 3tiorum bases excavatæe, ac in Macrouris. Carapax suturâ longitudinali utrinque notatus, ac in Brachyuris.

Tribus III. MACROURA.-Corpus multum elongatum. Abdomen elongatum et appendicibus seriatis instructum, vix inflexum, vel 
rectum. Branchiæ numcro sæpius plures quam novem. Vulvæ in pedum 3tiorum bases excavatx. Carapax sutura longitudinali raro utrinque notatus.

\section{ORDO II. ANOMOBRANCHIATA.}

Branchix sive apud pedum bases thoracis dispositæ et apertæ, sive appendicibus abdominis appendiculatx, sivc omnino obsoletro.

Tribus I. MYSIDEA.-Corpus formâ fere Caridoideum, non depressum. Pedes thoracis et maxillipedes nulli prehensiles, graciles, sæpius palpigeri, palpo prope thoracem insiti.

Tribus II. AMPHIONIDEA.-Corpus depressum, sæpe latum. Pedes thoracis et maxillipedes nulli prehensiles, palpigeri, palpo a thorace remoto.

TrIBUS III. SQUILLOIDEA.—Corpus valde depressum. Pedes quatuor et maxillipedes quatuor monodactyli prehensiles.

\section{SUBCLASSIS II. TETRADECAPODA.}

Annuli cephalothoracis cephalici numero septem. Oculi sessiles. Appendices branchiales simplicissimæ, sive thoracicx sive abdominales. Cephalothorax multi-annulatus, carapace carens, pedibus seriatis instructus. Abdomen appendicibus seriatis instructum, raro obsolescens.

\section{ORDO I. CHORISTOPODA.}

Ccphalothorax pedibus unguiculatis interdum partim chelatis instructus, pare utroque ad annulum singulum pertinente.

Tribus I. ISOPODA.-Pedes thoracis seriei anterioris numcro scx seriei posterioris octo, appendicibus branchialibus non instructi. Abdomen breve, appendicibus decem anticis branchialibus, duobus posticis styliformibus vel lamellatis. 
TrIBUS II. ANISOPODA.-Pedes thoracis scriei antcrioris numero octo, seriei posterioris numero sex, appendicibus branchialibus non instructi. Abdomen sat breve, appendicibus decem anticis branchialibus vel subnatatoriis, duobus posticis ac in Isopodis.

TRIBUS III. AMPHIPODA.-Pcdes thoracis seriei anterioris numero octo, seriei posterioris numero sex, appendicibus branchialibus partim instructi. Abdomen clongatum, appendicibus scx natatoriis sex styliformibus instructi.

ORDo II. TRILOBITA.-(An hujus sedis?)

?-Cephalothorax appendicibus lamellatis infra instructus haud pedibus unguiculatis. Segmenta corporis numero ab normâ sæpe multiplicata.

\section{SUBCLASSIS III. ENTOMOSTRACA.}

Annuli cephalothoracis cephalici numero sex vel quinque. Oculi sæpissime sessiles. Appendices brancliales sæpissime nullæ. Abdomen appendicibus seriatis non instructum. Cephalothorax pedibus seriatis instructus, octo vel decem posticis ad aunulos 8vum-11mum vel 12mum pertinentibus (si non obsoletis), sæpius natatoriis.

\section{ORDO I. GNATHOSTOMATA.}

Os mandibulis maxillisque normalibus instructum, non trunciforme nec suctorium.

LEG10 I. LOPHYROPODA.-Appendices cephalothoracis et segmenta numerum normalem non superantes.

TRIBUS I. CYCLOPOIDEA.-Cephalothorax annulatus et carapace non instructus. Abdomen rectum et non inflexum. Appendices 
cephalothoracis mandibulares et sequentes numero $16-18$, posticis 8-10 natatoriis.

Tribus II. DAPHNIOIDEA.-Corpus carnpace plerumque tectum, abdomine plus minusve inflexo. Appendices cephalothoracis mandibulares et sequentes numero $12-16,6-8$ posticis subnatatoriis.

Tribus III. CYPROIDEA.-Corpus earapace bivalvi omnino tectum et bene elausum, abdomine bene inflexo. Appendices cephalothoracis mandibulares et sequentes numero 10 , nullis natatoriis.

LEGIO II. PHYLLOPODA.-Appendices segmentoque cephalothoracis numerum normalem superantes, corpore immodieè annulato.

Tribus I. ARTEMIOIDEA.-Corpus fere rectum. Cephalotliorax multiannulatus testî sive teetus sive non tectus. Appendices eephalothoracis plerumque foliaeex. Oculi pedunculati. Styli caudales fere ac in Cyclopoideis.

Tribus II. APODOIDEA. - Cephalothorax testâ scutiformi tectus. Appendiees cephalothoracis posteriores lamellatæ. Oeuli sessiles Abdomen multiannulatum. Extremitas eaudalis formâ mirabilis.

Tribus III. LIMNADIOIDEA.-Corpus testâ omnino teetum enpite abdomineque inclusis ac in Cyproideis. Oculi sessiles. Extremitas caudalis ac in Cyproideis.

\section{ORDO II. CORMOSTCMATA.}

Os trunciforme et suctorium, basi sæpe mobile.

\section{SUBORDo I. PECILOPODA.}

Quoad formam eorporis Cyclopoideis plerumque affinia, sape peltata, interdum subeylindrica, quoque vermiformia. Os inferius.

Tribus I. ERGASILOIDEA.-Cephalothorax annulatus, earapace non tectus. Truncus buccalis non mobilis, brevis, mandibulis interdum obsoletis (?). Pedes 8 postiei bene natatorii ac in Cyclopoideis. Ova externa in saceulos gesta. Corpus sæpius non depressum. 
Tribus II. CALIGOIDEA.-Cephalothorax sive annulatus sive carapace tectus. Truncus buccalis mobilis, mandibulis armatus. Pcdes 8 postici plus minusve natatorii, sæpe partim in laminis coaliti. Ova externa in tubos longos uniseriatim gesta, tubis raro obsoletis. Corpus sæpius valde deprcssum et peltatum.

Tribus III. LERN EOIDEA.-Ccphalothorax vix annulatus. Corpus sive breve et obesum sive elongate vermiforme. Pedes natatorii obsoleti. Ova cxterna sive in sacculos aggregata sive in tubos uniseriata.

SUBORDO II. ARACHNOPODA.

Quoad formam corporis fere Arachnoidea, abdomine plerumque obsoleto, cephalothorace brevi, annulato, pedibus longis diffusis. Os trunciforme frontale.

Tribus PYCNOGONOIDEA.

ORDO III. MEROS'TOMATA.

Os pedum basibus in locis mandibularum et maxillarum instructum.

Tribus LIMULOIDEA.

SUbCLASSIS IV. CIRRIPEDIA.

Annuli cephalothoracis cephalici numero sex vel quinque. Oculi sessiles vel obsoleti. Appendices branchiales nullæ. Abdomen obsoletum. Animal sessile in testam multivalvatam inclusum quæ nunquam in nullâ parte extus exuitur. Cephalothorax pedibus seriatis tenuibus multiarticulatis instructus. 
Subclassis V. ROTATORIA.

Corpus minutum, pedibus totis carens et ciliis motum. Abdomen sæpe 2-3 annulatum et apice furcatum, interdum obsoletum. Annuli cephalothoracis cephalici numero quinque vel quatuor.

After this exposition of the subclasses, orders, and tribes, of the class Crustacea, here follows

\section{A S Y N O P S I S}

\section{OF THE FAMILIES AND SUBFAMILIES OF THE HIGHER SUBDIVISIONS OF CRUSTACEA.}

\section{Subclassis I. DECA PODA.}

\section{Ordo I. EUBRANCHIATA.}

\section{Tribus I. BRACHYURA:}

Subtribus I. MAIÖIDEA.

Legio I. MAIINEA vel Maiordea Trprca.-Corpus sæpissime oblongum, sæpius antice angustum et rostratum. Articulus antennarum externarum 1mus sub oculo insitis, anteriusque productus, testâ externâ sine suturâ coalitus. Pedes formâ normales."*

* We have modified the arrangement of the Maioidea, by separating from the family Maiadx, the families Inachida and Mithracida. The peculiarity of the outer maxillipeds, adopted by De Haan as the characteristic of the Inachidx, appears to be of suffeient value to authorize the exparation of the genera of this kind from the other Maiidr, although not so important as to require the union of the Eurypodii with the Inachidx, as done by this author. The Mithraces have a distinct eharacter, removing them from the other Maioids. There is in the species Mithrax, a singular diversity of form 
Fam. I. INACHID A.-Oculi in orbitis retractiles. Articulus maxillipedis externi 3 tius apice 4 tum gerens. Digiti acuminati. [Pedes prælongi.]

1. Macrocheirine.-Carapax late ovatus. Rostrum furcatum. Oculi oblongi. -G. Macrocheira, De H.

2. Inachins.-Carapax triangulato-ovatus. Rostrum emarginatum aut integrum. -G. Inachus, Fab., Nicrorhynchus, Bell.

3. SALACINAs.-Oculi perbreves. Rostrum fere obsoletum, non bifidum. Corpus non oblongum. Pedes 8 postici longi et erassi.-G. Salacia, E. and Lucas.

Fam. II. MAIIDÆ-Oculi in orbitis retractiles. Articulus maxillipedis externi 3tius angulo interno 4 tum gerens. Digiti acuminati.

1. Oculi latera capitis insiti et plus minusve lateraliter porrecti.

1. Libinina.-Rostrum apice emarginatum. Corpus paulo oblongum, subglobosum, lateribus altis. Oculi perbreves. Pedes sive longi sive mediocres.-G. Egeria, Lat., Doclea, Lcach, Libidoclea, E. and L., Libiniu, Lh.

2. Mainde-Carapax orbiculato-ovatus, rostro prominente profunde bifido. Pars antennarum externarum mobilis margine orbitæe orta.-G. Maia, Lk., Dione, De H.

3. Pisind.-Carapax triangulato-ovatus, rostro bifido, non deflexo. Pars antennarum externarum mobilis margine orbita exclusa, et sub rostro non cclata.-G. Paramithrax, E., Pisa, Ih., Pelia, Bell, Lissa, Lh., Rhodia, Bell, Hyas, Lh., Pisoides, E. and L., Herbstia, E., Thoe, Bcll, Dehaanius, M'L.

4. Prionorhynchina.-Pisin is affines. Rostrum breve, latissimum, bilobatum, non deflexum.-G. Prionorhynchus, H. and J. •

5. Micippin ж.-Rostrum latum, deflexum.-G. Micippa, Lh.

6. Chorinins.-Carapax triangulato-ovatus. Rostrum furcatuin. Pars antennarum externarum mobilis sub rostro celati.-G. Chorinus, Ih., Chorilia, D., Lahaina, D., Naxia, E., Scyra, D., Hyastenus, Whitc, Pyria, D.

2. Oculi frontales et porrecti longitudinales, carapace antice truncato.

7. Отноnin ж.-Oculi elongati, cylindrici.-G. Othonia.

[Cujus scdis est Siphonocetes, Kr.]

Fam. III. MITHRACID E.-Oculi et maxillipedes externi ac in Maiidis. Digiti versus apicem excavati et non acuminati.

1. Mrthracinse.-Oculi longitudine mediocres.-G. Mithrax, Lh., Mithraculus, W.

2. Cychacin as.-Oculi longi.-G. Cyclax, D.

exceeding what is found in any other genus of Maioidea. This fact, in connexion with the habits of the species, and the peculiarity of the fingers, scems to require the institution of a distinct family of Mithracida. 
Fam. IV. TYCHID A.-Oculi retractiles sed orbitis carentes, infra carapacem sese latentes.

1. Criocarcininse.-Rostrum valde deflexum. Carapax oblongus.-G. Criocarcinus, Guer.

2. Trchins.-Carapax oblongus, antice latus, latitudino trans-orbitali magnâ, rostro non deflexo, sat longo, fureato. Oeuli apiee paululum exserti-G. Tyche, Bell.

3. Camposcins.-Carapax oblongus, rostro fere obsoleto, emarginato. Pedes 8 postiei longi. Oeuli elongate peduneulati et exserti.-G. Camposcia, Lat.

Fam. V. EURYPODIDA.-Oculi retractiles ad carapacis latus, non sese latentes.

1. EuRYPODIN IE.-Antennæe externæo apertæ. Carapax triangulato-ovatus, rostro longo, fureato. Pedes longi. Oeuli longi et elongate salientes. Spina postorbitalis oblonga.-G. Eurypodius, Guer., Oregonia, D.

2. Amatimin. - [An oculi retractiles et species hujus sedis?] Antennæe externæ sub rostro celatæ. Carapax triangulato-ovatus, rostro fureato, latitudino transorbitali perangustâ. Pedes longi.-G. Amathia, Roux.

Fam. VI. LEPTOPODID $\dot{A}$.-Oculi non retractiles. Pedes prolongi.

\section{A. Antennæ externæ apertæ.}

1. Ach sinds.-Carapax triangulato-ovatus, rostrò perbrevi, bifido. Oeuli longi et elongate salientes. Pedes 4 postici subprehensiles.-G. Achoeus, Lh.

2. Inachoidine.-Carapax triangulato-ovatus, rostro elongato, simplico.-G. Inachoides, E. and L.

B. Antennce externæ sub rostro celatæ.

3. Leptopodine.-Carnpax triangulato-ovatus, rostro elongato, simplice. Pedes longissimi.-G. Leptopodia, Lh.

4. Stenorhynchin ж.-Carapax triangulato-ovatus, rostro breve, bifido.-G. Stenorhynchus, Lk.

Fam. VII. PERICERID A.-Oculi non retractiles. Pedes longitudine mediocres.

\section{A. Antennæ externæ apertæ.}

1. Paramicippinæ.-Rostrum valde deflexum. Micippoe aspeetu similes.-G. Paramicippa, E.

2. Pericerine.-Rostrum profundè bifidum, non deflexum.-G. Pericera, Lat., Tiarinia, D., Perinia, D., Halimus, Lat., Pugettia, D. 
3. Menmerhin.w.-Rostrum integrum vel subintegrum.-G. Menæthius, E., Acanthonyx, Lat., Ancilibinia, M'L., Peltinia, D.

B. Antenna externx sub rostro celatx.

4. Stenocionoprna. - Oeuli pralongi. Rostrum longum, fureatum, cornibus styliformibus, divarieatis.-G. Stenocionops, Lat.

5. Epialtin at.-Oeuli longitudine aut medioeres aut perbreves. Rostrum oblongum, erassum, sive integrum, sive emarginatum. Antennæ externæ apicem rostri sæpius non attingentes. Pedes 8 postiei subeylindriei.-G. Epialtus, E., Huenia, De H., Xenocarcinus, W., Leucippa, E.

Legio II. PARThenopinea vel MaIoidea Cancridica.-Corpus sive breviter triangulatum sive valde transversum et antice arcuatum. Articulus antennarum externarum 1mus oculo interior, rarissimè solutus, sæpius suturâ infixus, raro sine suturâ externâ coalescens. Pedes antici longiores, toti formâ normales.

Fam. I. PARTHENOPIDA.-Oculi retractiles. Carapax lateraliter non bene expansus.

G. Parthenope, Fab., Lambrus, Lh., Eurynome, Lh.

Fam. II. EUMEDONID A.-Oculi non retractiles. Carapax lateraliter non bene expansus.

G. Eumedonus, E., Ceratocarcinus, W. (Harrovia, W.) [An hujus sedis Gonatonotus, A. and W. Crust. Sam., tab. vi. f. 7.]

Fam. III. CRYPTOPODID Æ.-Oculi retractiles. Carapax lateraliter valde expansus, pedes 8 posticos plerumque tegens.

G. Cryptopodia, E., Eurynolambrus, E., Tlos, W.

Fam. IV. TRICHID A.-Parthenopidis quoad oculos carapacemque affinis; sed quoad maxillipedes externos Dromiis.

G. Trichia, De H.

LEgro III. ONCININEA vel Maroidea Dromidica.-Corpus triangulatum. Antennæ externæ e basi solutæ, cylindricæ. Pedes postici breviores, subdorsales, uncinato-prehensiles.

Fam. I. ONCINOPIDA.

G. Oncinopus, De H. 


\section{Subtribus II. CANCROIDEA.}

Legio I. CANCRINEA vel Cancroidea Trpica. - Species marin vel maritimæ. Antennæ quatuor conspicuæ. Cavitas branchialis superficie non papillo-spongiosa.

\section{Pedes postici gressorii.}

Fam. I. CANCRID ÆE.-Palatum colliculo longitudinali utrinque non bene divisum. Carapax sæpius late transversus, interdum angustus. Antennæ internæ plus minusve longitudinales.

1. Cancrinze.-Frons interorbitalis perangustus. G. Cancer, Leaeh, Perimela, Lh.

Fam. II. XANTHID Æ.-Palatum et carapax ac in Cancridis. Antennæ internæ plus minusve transversæ.

1. Xanthin ж.-Antennæ externæ basi firme infixæ, parte mobili ex hiatu orbitæ non exclusâ. Frons interorbitalis latior. Digiti aeuminati.-G. Atergatis, De H., Carpilius, Lh., De H., Liomera, D., Liagora, De H., Actaa, De H., D., Xantho, Jh. (subgenera Xantho, Euxanthus, D., Xanthodes, D., Paraxanthus, Lueas), Menippe, De H., Panopreus, E., Medrus, D., Halimede, De H.

2. Chiorodin $3 .-$ Antennx internx transversa. Antennx externx basi firme infixa, parte mobili ex hiatu orbita raro exclusâ. Frons interorbitalis latior. Digiti instar eoehlearis exeavati. [Quoad genera Xanthina et Chlorodinx ferme parallelæ.]-G. Etisus, Lb., Carpilodes, D., Zozymus, Lh., Actæodes, D., Daïra, De H., Chlorodius, Lh. (subgenera Chlorodius, Pilodius, D., Cyclodius, D.), Cymo, De H.

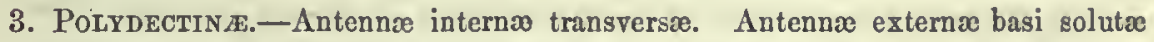
et libers.-[An Pilumnis propinquior.]-G. Polydectus, E.

Fam. III. ERIPHID E.-Palatum colliculo longitudinali utrinque bene divisum. Carapax sæpius angustus, interdum latus, margine antero-laterali raro longiore quam postero-lateralis, latitudine antemedianâ sæpissimè longiore, oculis remotis.

1. CEthrin ж.-Carapax transversus, lateribus valde dilatatis et rotundatis. $\mathrm{An}$. tennæ internæ fere longitudinales.-G. Ethra, Lh.

2. Ozrnse.-Carapax plus minusve transversus, lateribus non dilatatis. Digiti aeuminati. Antennæ internæ transversæ. Orbita hiatu interno basi antennæe oeeupato instrueta. Abdomen maris 7-artieulatum.-G. Galene, De H., Ozius, E., Pseudozius, D., Pilumnus, Lb., Pilumnoides, E. and L., Melia, E. [An hujus sedis Acanthodes, De H.?]

3. Aotumine.-Orbita Ozinis similes. Digiti instar eochlearis exearati.- $Q$. Actumnus, D. 
4. Eniphin x.-Orbita infra benc elausa, hiatu interno carens, articulo antennæ basali ex orbitâ omnino excluso. Carapax sive paulo transversus sive subquadratus. G. Ruppellia, E., Eriphia, Lat., Domacius, Souleyct, Trapezia, Lat., Tctralia, D., Quadrella, D.

\section{Pedes postici natatorii.}

Fam. IV. PORTUNID Æ.-Ramus maxillipedis Imi internus lobo interno instructus. Palatum sæpius colliculo longitudinali utrinque divisum.

1. LUPINA.-Sutura sterni mediana tria segmenta intersecans. Palatum eolliculis prominentibus.-G. Scylla, De H., Lupa, Lh., Amphitrite, De H., D., Carupa, D., Thalamita, Lat., Charybdis, De H., D., Lissocarcinus, W.

2. Arendeinf.-Sutura sterni mediana tria segmenta intersecans. Palatum colliculis non divisum. Ramus maxillipedis 1 mi internus ad apicem late transversim triangulatus, ramis duobus inter se fere convenientibus.-G. Arenæus, D.

3. Portunid s. - Sutura sterni mediana duo segmenta intersecans. Palatum colliculis sæpe obsolctis._G. Portunus, Fab.

Fam. V. PLATYONYCHID A.-Ramus maxillipedis $1 \mathrm{mi}$ internus non lobatus. Palatum colliculis non divisum.

G. Carcinus, Lh., Portumnus, Lh., Platyonychus, Lat., Polybius, Lh.

Legio II. TeliphUSinea vel Cancroidea Grapsidica. - Species fluviales. Antennæ quatuor conspicuæ. Cavitas branchialis permagna ac in Grapsoideis, superficie sæpe papillo-spongiosis.

Fam. I. TELPHUSID A.

G. Telphusa, Lat., Valdivia, W., Potamia, Lat., Trichodactylus, Lat., Orthostoma, Randall.

Legro III. CyCLINEA vel Cancroidea Corystidica.-Antennæ externx obsolctæ. Carapax angustus vel suborbicularis.

Fam. I. ACANTHOCYCLIDA.

G. Acanthocyclus, Lucas.

SUbTRIBUs III. CORYSTOIDEA.

Fam. I. TRICHOCERIDA.-Carapax formâ Cancroideus, fronte non rostratus. Antennæ internæ longitudinales. Antcnnæ externæ 
breves, flagello parce piloso. Maxillipedes externi super epistoma non producti, sed marginem arex buccalis bene adaptati.

G. Trichocera, De H.

Fam. II. THIID E.-Carapax suborbicularis, non oblongus, fronte non rostratus. Antennæo internæ transversæ vel obliqux. Antennæ externæ breves, flagello parce piloso. Maxillipedes externi super epistoma producti.

G. Thia, Lh., Kraussia, D.

Fam. III. CORYSTID A.-Carapax sive suborbicularis sive multum angustus, fronte plus minusve rostrato. Maxillipedes externi super epistoma producti.

G. Telmessus, W., Atelecyclus, Lh., Peltarion, H. and Jaeq., Pseudocorystcs, E., Gomeza, Gray, Eidia, De H. (partim), Corystes, Lat., Dicera, De H.

SUBTRIBUS IV. GRAPSOIDEA.

1. Articulus maxillipedis externi 4 tus cum angulo 3 tio interno articulatus.

Fam. I. GONOPLACID $A$ E.-Carapax transversus. Frons 4 tâ parte latitudinis carapacis longior, paulo deflexus, lamellatus. Antennæ internæ transversæ. Articulus abdominis maris 2 dus sterno contiguo angustior.

G. Eucrate, De H., Curtonotus, De H., Gonoplax, Lh.

2. Articulus maxillipcdis externi 4 tus cum anguto 3 tii apicali interno non articulatus sed medio marginis apicalis sive angulo externo.

Fam. II. MACROPHTHALMID A.-Oculi 3tiâ parte carapacis non breviores. Carapax subquadratus, sæpissime transversus, antice latissimus, angulis anticis acutis, lateribus non arcuatis. Antennæ internæ sive transversæ sive longitudinales. Articulus abdominis maris 2 dus sterno contiguo angustior. Articulus maxillipedis externi 3tius cristâ obliquâ piliferâ nunquam ornatus.

1. Macrophtmalmins.-Antennæ internæ transversæ sub fronte insitæ. Antennæ externæ basi ad frontem appressæo. Artieulus maxillipedis externi 4 tus apertus.-G. Cleistostoma, De H., Macrophthalmus, Lat.

2. Ocyponin ж.-Antennæ internæ longitudinales, juxta frontem utrinque insitæ. 
Antennæ externa a frante paulum remota. Articulus maxillipedis externi 4 tus apertus, 3 tius 2 do minor-G. Gelasimus, Lat., Helocius, D., Ocypoda, Fab., Scopimera, De H.

3. Dotinж.-Articuli maxillipedis externi 4 tus et scquentes 3 tio cclati.-G. Doto, De $\mathrm{H}$.

Fam. III. GRAPSID A.-Oculi 3tiâ parte latitudinis carapacis breviores. Carapax 'subquadratus, sæpius depressus, lateribus aut rectis aut arcuatis. Antennæ internæ transversæ. Articulus abdominis maris 2dus sterno contiguo sæpius vix angustior. Articulus maxillipedis externi 3tius sive inornatús sive cristâ obliquâ piliferâ ornatus. Palatum colliculis (viarum efferentium limitibus) instructum.

1. Grapsinfe.-Antennæ internæ fronte tectæ. Articulus maxillipedis externi 3 tius cristâ obliquâ in 2 dum productâ non ornatus.-G. Pseudograpsus, E., Heterograpsus, Lucas, Platynotus, De H., Brachynotus, De H., Trichopus, De H., Grapsus, Lk., Goniograpsus, D., Planes, Lh., Hcmigrapsus, D., Cyrtograpsus, D.

2. Sesarmin $2 .-A n t e n n æ$ interna fronte tectæ. Articulus maxillipedis externi 3 tius cristâ obliquâ in 2 dum produetâ notatus.-G. Sesarma, Say, Sarmatium, D., Cyclograpsus, E., Chasmagnathus, De H., Helice, De H.

3. Plagusinæa.-Antennæ internæ sinubus frontis longitudinalibus apcrtæ.-G. Acanthopus, De H., Plagusia, Lat.

Fam. IV. GECARCINID A.-Oculi breves. Carapax obesus, paulo transversus, antice latus, curvatim declivis, lateribus arcuatis et pone oculos largè rotundati et vix dentatis. Antennæ internæ transversæ. Articulus abdominis maris 2dus sterno postico vix angustior. Articulus maxillipedis externi 3tius cristâ obliquâ pliferâ non ornatus. Palatum colliculis (viarum efferentium limitibus) non instructum.

1. Udasnet-Articulus maxillipedis externi 4tus apertus.-G. Uca, Lh., Gecarcinicus, E., Cardisoma, Lat., Gecarcoidea, E.

2. Gecarornin E.-Articuli maxillipedis externi 4 tus et sequentes 3 tio celati.-G. Gecarcinus, Lat.

Fam. V. PINNOTHERIDÆ. - Oculi perbreves orbitis insiti, raro non retractiles. Carapax sive obesus sive depressus, raro paulo oblongus et interdum parce rostratus, lateribus valde rotundatis. Antennæ internæ aut transversæ aut obliquæ. Abdomen maris angustum, versus basin sterno contiguo valde angustius. Palatum colliculis (viarum efferentium limitibus) instructum. [Species totæe parvæ.]

1. Pinnotherina.-Articulus maxillipedis externi 2 dus parvulus aut obsoletus. 
Corpus sive obesum sive depressum.-G. Pinnothera, Lat., Fabia, D., Xenophthalmus, W., Xanthasia, W., Pinnixa, W., Pinnotherelia, Lucas.

2. HyMentorns.-Corpus sepius pareo rostratum, depressum. Articulus mazillipedis externi 2 dus dimidio 3 tii major.-G. Hymenosoma, Lh., Halicarcinus, W., Iymenicus, D., Elamena, E.

Fam. VI. MYCTIRID Æ.-Corpus obesum. Carapax antice perangustus, vix rostratus, orbitis carentes. Antennx internæe parvula, longitudinales.

G. Myctiris, Lat.

Subtribus V. LEUCOSOIDEA.

1. Appendices maris genitales basi pedum 5torum orta. [Via afferens pone regionem pterygostomianam ingrediens.]

Fam. I. CALAPPIDA.-Articuli maxillipedis externi terminales non celati.

1. Calapprna.-Pedes nulli natatorii.-G. Calappa, Fab., Platymera, E., Mursia, E., Cycloes, De H.

2. OrITHYin e.-Pedes 8 postici natatorii.-G. Orithyia.

Fam. II. MATUTID正.-Articuli maxillipedis externi terminales celati, 3 tio triangulato, palpo vix longiore quam articulus 2 dus.

G. Mepatus, Lat., Thealia, Lucas, Matuta, Fab.

2. Appendices maris genitales sterno ortx.

Fam. III. LEUCOSID A.-Via afferens apud angulum palati' anterolateralem ingrediens. Articuli maxillipedis externi terminales precedentibus tecti. Pedes postici ad normam gressorii.

G. Philyra, Lh., Leucosia, Fab., Leucisca, M'L., Ebalia, Lh., Nucia, D., Nursia, Lh., Mlia, Lh., Myra, Lh., Persephona, Lh., Ixa, Lh., Iphis, Lh., Areania, Lh., Oreophorus, Rüppell.

Fam. IV. DORIPPIDA.-Via afferens partem regionis pterygostomianæ posticam ingrediens. Articuli maxillipedis externi terminales precedentibus non tecti. Pedes $2-4$ postici subdorsales prehensiles.

G. Dorippe, Fab., Ethusa, Roux. 
Tribus II. ANOMOURA.

\section{Sectio I. Anomoura Superiora.}

Oculi antennis $1 \mathrm{mis}$ non anteriores. Antennæ $2 \mathrm{~d} \rightsquigarrow$ oculis interdum posteriores non exteriores. Abdomen angustum, ad sternum sæpius appressum, appendicibus caudalibus carens.

Subtribus I. DROMIdea, vel Anomoura Matidica Superiora.

Carapax subtriangulatus vel subquadratus vel suborbiculatus, fronte angusto, oculis approximatis. Pedes postici subdorsales. Via afferens uti in Maioideis.

Fam. I. DROMID E.

G. Dynomene, Lat., Dromia, Fab., Latreillia, Roux, Homola, Lh.

Fam. II. CYMOPOLID A.-[An hujus sedis ?]

G. Oymopolia, Roux, Caphyra, Guer.

Subtribus II. BELLIDEA, vel ANonoura Cancridica.

Carapax parce oblongus, subellipticus. Pedes 8 postici inter se similes. Via efferens uti in Dromideis.

Fam. I. BELLID $A$ E.

G. Corystoides, Lucas, Bellia, E.

Subtribus III. RANiNidea, vel Axomoura Leucosidica.

Carapax oblongus. Via efferens osque uti in Leucosoideis.

Fam. I. RANINID $Æ$.

G. Raninoides, E., Ranina, Lk., Ranilia, E., Notopus, De H., Lyreidus, De H., Cosmonotus, W. 


\section{Sectio II. Anomoura Media.}

Oculi antennis $1 \mathrm{mis}$ non anteriores. Antennæ $2 \mathrm{~d} \mathfrak{x}$ oculis posteriores et exteriores. Abdomen inflexum, sed non stricte appressum, appendicibus caudalibus instructum. Os nunquam uti in Leucosoideis.

Subtribus IV. HIPPIDEA, vel Anomoura Corystidica.

Carapax oblongus. Maxillipedes externi operculiformes, articulo 3tio elongato et lato. Pedes 2 di 3 tii 4 tique natatorii, 5ti debiles inflexi.

Fam. HIPPID $A$.

G. Albunce, Fab., Albunhippa, E., Remipes, Lat., Hippa, Fab.

Subtribds V. PORCELLANIDEA, rel Anomodra Grapsidica.

Carapax suborbiculatus. Maxillipedes externi male operculiformes, articulo 3 tio paulo minore quam 2 dus. Pedes 2 di 3 tii 4 tique gressorii, 5ti debiles, inflexi.

Fam. PORCELLANID E.

G. Porcellana, Lamarck.

\section{Sectio III. Anomoura Submedia.}

Oculi antennis $1 \mathrm{mis}$ plane anteriores. Abdomen valde dilatatum, inflexum sed stricte non appressum, appendicibus caudalibus carens.

Subtribes VI. LITHOdEA, vel Anomoura Maimdica Submedia.

Carapax subtriangulatus uti in Maioideis. Abdomen latum, vix symmetricum. Pedes nulli natatorii, 2 dis 3 tiis 4 tisque consimilibus, 5 tis parvulis, sub carapace inflexis. 
Fam. LTTHODID E.

G. Lithodes, Lat., Lomis, De H., Echidnocerus, W.

\section{Sectio IV. ANomodra Inferiora.}

Oculi antennis $1 \mathrm{mis}$ anteriores. Antennæ $2 \mathrm{~d} \rightsquigarrow$ oculis posteriores et exteriores. Abdomen elongatum, vix inflexum, appendicibus caudalibus instructum, sæpe appendicibus quoque ventralibus.

Subtribus VII. PAGURIDEA, vel Anomoura Maiddica Inferiora.

Carapax oblongus, postice mollior. Abdomen plerumque molle vel carnosum, appendicibus imparibus sæpius instructum. Pedum pares 3 tii 4 ti dissimiles.

Fam. I. PAGURID Æ.-Antennæ internæ mediocres, articulo Imo brevissimo. Maxillipedis externi palpus flagello multiarticulato instructus.-Species aquaticæ vel littorinæ.

1. Pagurins.-Abdomen asymmetricum.-G. Paguristes, D., Diogenes, D., Bernhardus, D., Pagurus, Calcinus, D., Aniculus, D., Clibanarius, D.

2. Canceldise.-Abdomen symmetricum.-G. Cancellus, E.

Fam. II. CENOBITID.F.-Antennæ internæ multo elongatæ, articulo 1mo oculis sæpius longiore, valde deflexo. Maxillipedis externi palpus flagello non instructus. Species præcipue terrestriales.

G. Cenobita, Lat., Birgus, Lh.

Subtribus ViII. Aegleidea.

Carapax elongatus, texturâ omnino crustaceus. Abdomen extus crustaceum, maris paribus appendicum obsoletis, femince elongatis, instructum. Pedum pares 3 tii 4 tique consimiles; 5ti debiles, sub carapace inflexi. Branchiæ filosæ.

Fam. AGLEID E.

G. Afglca, Lh. 
Subtribus IX. GALATHEIDEA.

Carapax elongatus, texturâ superficiei omnino crustaceus. Abdomen extus crustaceum, maris feminoeque paribus appendicum elongatis infra instructum. Pedum pares 3tii 4 tique consimiles, 5ti debiles juxta carapacem inflexi. Branchiæ foliosæ.

Fam. GALATHEIDA.

G. Munida, Ihh., Galathea, Fab., Grimothea, Lh.

APPENDIX. MEGALOPIDEA.

G. Marestia, D., Monolepis, Say, Megalopa, Lh., Cyllene, D., Tribola, D.

Tribos III. MACROURA.

Sectio I. Macrodra Pagdro-SqUillidica.

SUBTRIBUS I. THALASSINIDEA.

Carapax duabus suturis longitudinalibus subdivisus, sæpeque suturâ dorsali transversâ. Antennæ externæ squamâ basali nullâ vel parvâ instructæ. Pedes 6 postici directione non consimiles; duo antici longiores et crassiores, fossorii et sæpius chelati.

Legro I: THALASSINIDEA EUBRANCHIATA. - Species branchiis thoracicis instructæe tantum.

Fam. I. GEBID Æ.-Maxillipedes externi pediformes. Appendices caudales et aliæ abdominales latæ.

G. Gebia, Lh., Axius, Lh., Calocaris, Bell, Laomedia, De H., Glaucothoe, E.

Fam. II. CALLIANASSIDA.-Maxillipedes externi operculiformes. Appendices caudales latæo.

G. Callianassa, Lh., Trypæa, D. 
Fam. III. THALASSINID A. - Maxillipedes externi pediformes. Appendices caudales lineares.

G. Thalassina, Lat.

Legro II. THALASSINIDEA ANOMOBRANCHIATA. - Pedes abdominis appendicibus branchialibus instructi.

Fam. I. CALLISEID $\approx$.

G. Callianidea, E., Callisea, Guer., D.

\section{Sectio II. Macrodra Normalia.}

Subtribus I. AStacidea, rel Macroura Supertora.

Carapax suturâ dorsali transversâ sæpius notatus, suturis longitudinalibus obsoletis, testâ antero-laterali cum epistomate connatâ. Antennæ externæ squanâ basali sive nullâ sive parvâ instructæ. Pedes 6 postici directione sat consimiles; antici crassiores, sive didactyli sive non didactyli. [Branchiæ filosæ.]

1. Antennoe externce squamâ basali carentes. Pedes antici monodactyli.

Fam. I. SCYLLARID E._Carapax valde depressus, margine cephalothoracis utrinque tenui, carapace lateraliter subito inflexo. Antennæ externæ laminatæ breves. Sternum trigonum.

G. Scyllarus, Fab., Arctus, D., Thenus, Lh., Parribacus, D., Ibacus, Lh.

Fam. II. PALINURID A.-Carapax subcylindricus, lateraliter late rotundatus. Antennæ externæ basi subcylindricæ, longæ. Sternum trigonum.

G. Pulinurus, Fab., Panulirus, Gray.

2. Antennæe externæe squamá basali instructe. Pedes antici didactyli.

Fam. III. ERYONID A.-Carapax non oblongus, depressus, lateribus subito inflexis, abdomine multo angustiore.

G. Eiyon, Desmarest. 
Fam. IV. ASTACIDA.-Carapax oblongus, subcylindricus, abdomine parce angustiore. Sternum angustum.

1. Astacin x.-Manus crasse et lato, superficio convexa.-G. Homame, E., Astacoides, Guer. (subgenera Astacoidcs, Cheraps, Erich.) Astacus (subgencra Astacus, Cambarus, Erich.)

2. Nepiropinж.-Manus prismatica, lateribus fere recto.-G. Nephrops, Lh. Paranephrops, W.

Subtribus II. CARIDEA, vel Macroura Typica.

Carapax suturâ nullâ notatus, epistomate anticc non connatus. Antennæ externæ squamâ basali magnâ instructæ. Pedes 6 postici directione sat consimiles; Imi vel 2 di crassiores et chelati, 3 tii 4 tis similes. [Branchia foliosa.]

\section{Maxillipedes 2 di breves et lamellati.}

Fam. I. CRANGONID E. - Mandibulæ graciles, valde incurvatæ, non palpigerx, coronâ perangustâ, non dilatatâ. Pcdum pares $1 \mathrm{mi}$ 2 dique inter se valde inæqui.

1. Crangonine.-Pedes $1 \mathrm{mi} 2$ dis crassiores. Maxillipedes externi pediformes. Digitus mobilis in manus marginem claudens; immobilis spiniformis. Pedes 2di non annulati.-G. Crangon, Fab., Sabinea, Owen, Argis, Kr., Paracrangon, $\mathbf{D}$.

2. Lysmatine.-Pedes $1 \mathrm{mi} 2$ dis crassiores. Maxillipedes externi pediformes. Digiti subæqui, uno ad alterum claudente. Pedes 2 di annulati.-G. Nika, Risso, Lysmata, Risso, Cyclorhynchus, De H.

3. Gnathopiyluin ж.-Pedes 2 di 1 mis crassiorcs. Maxillipedes externi lati, operculiformes.-G. Gnathophyllum.

Fam. II. ATYID A.-Mandibulæ crassæ, non palpigeræ, coronâ latâ, parce bipartit, processu terminali brevi et dilatato. Pedum pares $1 \mathrm{mi} 2$ dique inter se æqui, carpo nunquam annulato.

1. Atrin dall, Curidina, $\mathrm{E}$.

2. Ephyrin ж.-Pedes thoracis palpo instructi-G. Ephyra, Roux.

Fam. III. PALEMONIDA. - Mandibulæe crass $x$, sive palpigeræe sive non palpigera, supra profunde bipartitr, processu apicali oblongo, angusto. 
1. AupHeIn 2 - - Pedes $1 \mathrm{mi}$ crassiores, chelati; 2 di fliformes, carpo sæpius annulato, plerumque chelato. Mandibulæ palpigcræ.-G. Alpheus, Fab., Bctæus, D., Alope, W., Athanas, Lh., Mippolyte, Lh., Rhyncocinetes, L.

2. Pandaline.-Pedes $1 \mathrm{mi}$ gracillimi, non chelati, 2 di filiformes, carpo annulato. -G. Pandalus, Lli.

3. Paldemonin.e-Pedes 4 antici chelati, 2 di 1 mis crassiores, carpis nullis annulatis. Pedes nulli palpigeri.-G. Pontonia, Lat., D., OEdipus, D., Marpilius, D., Anchistia, D. (An Periclimeni Costæ similis?) Palæmonella, D., Palæmon, Fab., Hymenocera, Lat., Cryphiops, D. [Hic Typton Costre, si non squama antennarum basalis nulla.]

4. OPLOPHORINE.-Pedes $1 \mathrm{mi}$ sive didactyli sive monódactyli; 2 di chelati, crassiores. Squama antennarum externarum. acuminata, extus spinis armata.-G. Oplophorus, E., Regulus, D.

[Cujus sedis Autonomea, Risso?].

\section{Maxillipedes 2 di tenuiter pediformes.}

Fam. IV. PASIPHAID Æ-Mandibulæ uti in Atyidis.

G. Pasiphra, Sav.

Subtribus III. PEN IEIDEA, rel Macroura INferiora.

Carapax suturâ nullâ notatus, cum epistomate antice non connatus. Antennæ externæ squamâ basali magnấ instructæ. Pedes $1 \mathrm{mi}$ 2 dique 3 tiis non crassiores, 3 tii sæpius crassiores longiores et chelati; raro pedes toti debiles et tenues, 3tiis sive obsolete chelatis sive non chelatis.

Fam. I. PEN AID A.-Pedes. 6 antici chelati, 3tii longiores et plus minusve validiores.

G. Sicyonia, E., Penæus, Lat., Aristeus, Duv., Stenopus, Lat., Spongicola, De H.

Fam. II. SERGESTID Æ.-Pedes toti debiles, 2di 3tiique consimiles, sive obsolete didactyli sive non didactyli. Maxillipedes externi tenues.

G. Sergestes, E., Acctes, E., Euphema, E. (An hujus sedis?)

Fam. III. EUCOPIDÆ.-Pedes toti debiles, 2di 3tiique non chelati, Imi maxillipedesque externi monodactyli et subprehensiles.

G. Eucopia, D. 


\section{Ordo II. ANOMOBRANCHIATA.}

\section{TRIBUS I. MYSIDEA.}

Fam. I. EUPHAUSID A.-Cephalothorax formâ Caridoideus. Pedes. thoracis bifidi, appendicibus branchialibus externis.

G. Thysanopoda, E., Euphausia, D., Cyrtopia, D.

Fam. II. MYSID $A$.-Cephalothorax formâ Caridoideus. Pedes thoracis bifidi, appendicibus branchialibus carentes.

1. Crnturna-Pedes abdominis appendicibus branchialibus instructi. Antenn» internæ birameæ, extcrnæ squamâ basali instructæ.-G. Cynthia, Thompson.

2. Mrsinew.-Pedes abdominis appendicibus branchialibus carentes. Antennæ internæ birameæ, externæ squamâ basali instructæ.-G. Mysis, Lat., Promysis, D., Macromysis, W., Siriella, D., Loxopis, D.

3. SCELETININ ke.-Pedes abdominis appendicibus branchiiformibus carentes. Antennæ internæ simplices, externæ birameæ, squamû basali carentes.-G. Sceletina, D., Rachitia, D., Myto, Kr.

Fam. III. LUCIFERID A.--Segmentum antennale valde elongatum carapace per suturam fere discretum. Pedes simplices.

G. Lucifer.

Appendix to the Mrsidea,-G. Furcilia, D., Calyptopis, D., Zoea. Bose.

Tribus II. AMPHIONIDEA.

Fam. I. AMPHIONID E.

G. Phyllosoma, Leach, Amphion, Edw.

Tribus III. SQUILLOIDEA.

Fam. I. SQUILLID FE.-Rostrum carapaxque per suturam disjuncti.

G. Lysiosquilla, D., Squilla, Pseudosquilla, Coronis, Lat., Gonodactylus, Lat.

Fam. II. ERICHTHIDA.-Rostrum est carapacis frons productus et acuminatus, carapace et rostro non disjunctis.

G. Squillerichthus, Edw., Erichthus, Lat., Alima, Lb. 


\section{Subclassis II. TETRADECAPODA. \\ ORDo I. CHORISTOPODA.}

Tribus I. ISOPODA.

SUBTRIBUS I. IDOTAEIDEA.

Appendices abdominales duæ postic $\infty$ bene operculiformes, appendices alias optime tegentes.

Fam. I. IDOT AID E.-Pedes fere consimiles, plus minusve ambulatorii.

G. Idotrea, Fab., Edotea, Guer., Erichsonia, D., Cleantis, D., Epelys, D.

Fam. II. CH gissimo, et multiarticulato.

G. Chretilia, D.

[An hujus sedis Anthuridoe.]

Subtribus II. ONISCOIDEA.

Appendices abdominales duæ posticæ styliformes et non operculiformes alias appendices tegentes sat terminales, raro obsoletx.

Fam. I. ARMADILLID $\mathbb{E}$.-Corpus bene convexum, stricte articulatum. Abdomen multiarticulatum, segmento ultimo parvo. Appendices caudales ultra abdomen non exsertæ, lamellatæ. Mandibulæ non palpigeræ. Antennæ internæ inconspicux.

1. Truins. - Appendiees eaudales infra abdominis segmentum postieum eelatr et opereuliformes sed parva et alias appendiees non tegentes.-G. Tylus, Lat.

2. Armadilinde.-Appendiees eaudales inter duo abdominis segmenta postiea partim visæ.-G. Armadillo, Lat., Spherillo, D., Armadillidium, Br., Diploexochus, Br.

Fam. II. ONISCID AE.-Corpus sæpius minus convexum, vel stricte vel laxe articulatum. Abdomen multiarticulatum, segmento ultimo 
parvo. Appendices caudales valde exsertæe, styliformes. Mandibulæ non palpigeræ. Antennæ internæ conspicuæ.

1. ONISCINÆ.-Maxillipedes 3-articulati, articulis duobus ultimis brevibus et parvulis. Antennæ externæx ad articulationem 5 tam bene geniculatæ. Basis appendicum eaudalium perbrevis, duos stylos multum inæequos gerens, stylo interno sub abdomine partim celato.-G. Oniscus, Linn. (subgen. Trichoniscus, Br., Porcellio, Lat., Oniscus), Philoscia, Platyarthrus, Br., Deto, Gucr.

2. Scyphacinse. - Maxillipedes 2-artieulati, articulo 2do lamellato. Antennæ externæ ad articulationem 5 tam non geniculata. Basis appendicum caudalinm aut brevis aut oblongus, ramo interno interdum omnino aperto.-G. Scyphax, D., Styloniscus, D.

3. Lyaina.-Maxillipedes 4-articulati, elongati. Antennæ externæ ad articulationem 5tam non bene geniculatæ. Styli caudales longi, basi longè exserto, ramis setiformibus, subæequis et æque apertis.-G. Lygia, Fab., Lygidium, Br.

Fam. III. ASELLID Æ.-Corpus sæpius plus depressum et laxè articulatum. Abdomen 1-6-articulatum, segmento ultimo magno, scutellato. Appendices caudales styliformes, interdum brevissimæ. Mandibulæ palpigeræ. Antennæ internæ conspicuæ.

1. Limnorine.-Abdomen 5-6-articulatum.-G. Limnoria, Lh.

2. Asellinfe.-Abdomen 1-2-articulatum.-G. Jaera, Lh., Joridina, E., Asellus, G., Janira, Lh., Henopomus, Kr., Munna, Kr.

\section{SubTribus III. CYMOTHOIDEA.}

Appendices abdominales duæ posticæ lamellatæ, apud abdominis latera dispositæ.

Fam. I. CYMOTHOID A.-Maxillipedes breves, 3-4-articulati, operculiformes, articulis terminalibus angustis brevibus. Appendices caudales liberæ, marginibus rarissimè ciliatæ. Antennæ sub capite infixæ. Abdomen 4-6-articulatum, segmentis anterioribus raro connatis. Pedes toti ancorales. Branchiæ sæpissime non ciliatæ. Epimeræ conspicuæ.

1. Сумотноinж.- Lamellæ caudales nudæ. Abdomen multiarticulatum, segmentis liberis.-G. Cymothoa, Fab., Ceratothoa, D., Livoneca, Lh., Anilocra, Lh., Nerocila, Lh., Olencira, Lh.

2. Orozeuktine. -Segmentum abdominis posticum ac in Cymothoa; segmenta alia coalita et non libcra.-G. Orozeuktes, E.

3. EaAthorn.s. - Lamellæ caudales eiliatæ. Abdomen multiarticulatum, segmentis liberis.-G. Elyathoa, D. 
Fam. II. AGID A.-Maxillipedes elongati, 4-6-articulati, articulis totis lamellatis, terminalibus latis et brevibus. Appendices caudales liberæ, marginibus ciliatæ. Antennæ ad frontis margincm capitis affixæ, apertæ. Abdomen 4-6-articulatum. Pedes 6 antici interdum ancorales aut prehensilcs, sæpius simpliciter unguiculati, 8 postici unguiculati ct nunquam ancorales. Branchiæ ciliatæ. Epimeræ conspicuæ.

1. Earne.-Pedes 6 antici ancorales, unguibus validis, reliquis unguibus parrulis confecti-G. Agga, Lh. (Subgen. AEga, Conilera, Lh., Rocinela, Lh.), Acherusia, Lucas, Pterelas, Guer.

2. Cirolanine.-Pedes nulli ancorales.-G. Cirolana, Lh., Corallana, D., Alitropus, E.

Fam. III. SPHEROMID A.- Maxillipedes elongatè 5-6-articulati et palpiformes. Appendices caudales margine abdominis laterali connatæ. Antennæ ad frontis marginem capitis affixæ, apertæ. Abdomen 1-2-articulatum. Pedes non ancoralcs (raro 4 antici ancorales). Branchiæ ciliatæ. Epimeræ non discerncndæ.

1. Spheroninæe.-Lamella appendicis caudalis externa sub internâ se latens.-G. Spheroma, Lat., Cymodocea, Lh., Cerceis, E., Cassidina, E., Amphoroideum, E.

2. NES жIN E.-Lamella appendicis caudalis externa saliens, sub internâ se non latens, usquam aperta. Pedes nulli ancorales.-G. Nescaa, Lh., E., Campecopea, Lh.

3. Ancrnines.-Pedes 4 antici ancorales.-G. Ancinus, E.

Tribus II. ANISOPODA.

Subtribus I. SEROLIDEA, vel Anrsopoda Crmothoica.

Appendices duæ posticæ abdominales lamellatæ, apud abdominis latera dispositæ.

Fam. I. SEROLID E.-Appendices abdominales sex anticæ liberæ, subnatatoriæ, quatuor sequentes branchiales, bene lamellatæ, ultimæ ac in Cymothoidis. Antennæ Imæ sub capite insitæ.

G. Serolis, Lh.

Fam. II. PRANIZIDA.-Appendices abdominales totre ac in Agidis. Antennæ Imæ sub capite insitæ. Pedes thoracis numero decem, paribus duobus anticis rudimcntariis. Thoracis segmenta numero quinque non superantia. 
1. Pranizin as.-Caput parvum. Mandibulo vix salientes.-G. Praniza, Lh.

2. Anceins.-Caput grande. Mandibulw ultra caput longe exsertio.-G. Anceus, Risso.

Subtribus II. ARCTURIDEA, vel ANisopoda Idotaica.

Appendices dux postic $x$ abdominales lamellatæ et bene operculiformes, appendices branchiales tegentes.

\section{Fam. I. ARCTURIDA.}

1. Aroturin ж.-Opercula abdominis ad ventrcm strictè appressa.-G. Arcturus, Lat., Leachia, Johnston.

2. Anthurin ж.-(An Idotæideorum?) Opercula abdominis ad ventrem non bene approssa, sed libera et latcra abdominis partim tegentia.-G. Anthura, Lh.

\section{Subtribus III. TANAIDEA, vel Anisopoda Oniscioa.}

Appendices duæ posticæ abdominales plus minusve styliformes, subterminales, interdum obsoletx.

Fam. I. TANAIDA.-Pedes 1mi 2dive subchelati, sequentes non ancorales. Abdomen paribus 5 appendicum subnatatoriis unoque postico stylorum instructum.

1. Tanainæ.-Corpus lincare, segmento thoracis 1mo sæe oblongo capiteque parvulo. Styli caudales longi. G. Tanais, E., Paratanais, D., Leptochelia, D., Apseudes, Lu., Rhoea, E.

2. LIRIOPINA.-Corpus antice latius, posticc sensim angustans, segmento thoracis $1 \mathrm{mo}$ reliquis vix longiore, capite sat grandi. Appendices abdominales numero deccm elongatæ.-G. Liriope, Rathke, Cryptothir, D.

3. Crossurina.-Corpus antice latius, postice sensim angustatum, segmento thoracis 1mo vix longiore, capite sat grandi. Appendices abdominalcs inferiores numero scx, ciliatæ.-G. Crossurus, Rathke.

Fam. II. BOPYRIDA.-Pedes toti plerumque aliquo modo subprehensiles vel ancorales. Maris corpus angustum; abdomen 1-6-articulatum, appendicibus subnatatoriis stylisque duobus sæpe instructum, totis appendicibus interdum obsoletis. Femina corpus latum et obesum, oculis carens, et quoad pedes sæpe partim obsoletum: 
1. BopYRINE.-Thorax femince appendicibus branchialibus carens. G. Bopyrus, Lat., Phryxus, Rathke, Cepon, Duv., Dajus, Kr.

2. IONIN.s. - Pedes thoracis feminae ad basin appendices simplices branchiales gerentcs.-G. Ione, Lat., Argeia, D.

\section{Tribus III. AMPHIPODA.}

\section{Subtribus I. CAPRELLIDEA.}

Maxillipedes elongati, palpiformes. Caput oculique mediocres. Abdomen obsolescens.

Fąm. I. CAPRELLID A.-Corpus longum et fere filiforme. Antennæ $2 \mathrm{~d} \rightsquigarrow$ longitudine mediocres. [Species non parisiticæ.]

G. Proto, Lh., Protella, D., Caprella, Lk., Eggina, Kr., Cercops, Kr., Podalirius, Kr.

Fam. II. CYAMIDA.-Corpus latum, depressum. Antennæ 2dx obsoletæ. [Species parasiticx.]

G. Cyamus.

\section{SubTribus II. GAMMARIDEA.}

Maxillipedes elongati, palpiformes. Caput oculique mediocres. Abdomen appendicibus sex natatoriis et sex styliformibus instructum.

Fam. I. DULICHID E.-Gressoriæ, habitı Caprelloideæ. Corpus lineare, epimeris obsoletis. Pedes sex posteriores longi, subprehensiles. Abdomen 5-articulatum.

G. Dulichia, Kr.

Fam. II. CHELURIDA.-Corpus fere cylindricum, epimeris mediocribus. Abdomen segmentis 4 to 5toque coalitis et oblongis, stylis caudalibus inter se valde dissimilibus.

G. Chelura, Philippi.

Fam. III. COROPHID $\AA .-$ Gressoriæ, pedibus partim lateraliter porrectis. Corpus plus minusve depressum, sæpe latum, epimeris perbrevibus, interdum obsoletis. Abdomen formâ appendicibusque normale et perfectum. Antennæ sæpe pediformes. 
1. Clxdoninze.-Styli caudales 1mi 2dique simplices, subulati.-G. Clydonia, D.

2. Coropuinse.-Antennæ plus minusve pediformes. Styli caudales $1 \mathrm{mi} 2$ dique biramei.-G. Corophium, Lat., Siphonocetes, Kr., Platophium, D., Cyrtophium, D., Unciola, Say, Podocerus, Lh., Cratophium, D., Cerapus, Say, Cerapodina, E., Erichthonius, E.

3. Icrunde-Antennæ non pediformes nee subpediformes, flagellis sat longis basique sat brevi instruetæ. Styli eaudales ae in Corophinis.-G. Icilius, D., Pterygocera, Lat.

Fam. IV. ORCHESTIDA. - Saltatorix, pedibus nullis lateraliter porrectis. Corpus compressum, epimeris magnis. Abdomen appendicibus normale. Antennæ non bene pediformes. Styli caudales Imi 2 dique biramei; 3 tii simpliees brevissimi et ultra 2 dos non producti. Mándibulæ non palpigeræ. Maxillæ $1 \mathrm{~m} \circledast$ palpo instructæ sive parvulo sive obsoleto.

G. Orchestia (subgen. Talitrus, Talorchestia, Orchestia), Allorchestes, D.

Fam. V. GAMMARIDA.-Saltatoriæ vel natatoriæ, pedibus nullis lateraliter porrectis. Corpus sæpius compressum, raro subdepressum, epimeris sive magnis sive parvis. Styli caudales laxiores, duobus ultimis oblongis sæpiusque ultra 2 dos produetis, interdum simplieibus. Mandibulæ sæpissime palpigeræ. Maxillæ $1 \mathrm{~m} x$ palpo magno 2-3-articulato (rarissime 1-articulato) instructæ.

\section{Pedes 10 postici non prehensiles.}

1. Steqocephatine.-Antennæ breves, superiores basi erassæ. Mandibulæ aeie denticulatâ instruetæ, palpo brevi uniarticulato intus dentato. Epimeræ pcrmagnæ.-G. Stegocephalus, Kr.

2. Lysianassin $\mathbb{E}$.-Antennæ breves, superiores basi crassæ. Mandibulæ apice paree dentatæ et acuminatæ, acie vix instructæ, palpo 2-3-articulato. Maxillipedes lamellis internis magnis. Epimeræ permagnæ.-G. Lysianassa, E., Phlias, Guer., Opis, Kr., Uristes, D., Anonyx, Kr., Urothoe, D.

3. Leucothoin zE.-Antenna superiores basi plus minusre graciles. Maxillipedes elongati, perangusti, articulo longo unguiformi confecti, lamellis internis perbrevibus. Mandibula sive palpigeræ sive non palpigeræ, proeessu molari carentes (An semper?). Epimera magna.-G. Stenothoe, D., Leucothoe, Lh.

[An hujus sedis, genus Michrocheles, Kr., et Amphithoe marionis, Edw. ?]

4. Gammarinæw-Antennæ $1 \mathrm{~m} \circledast$ basi graeiles. Maxillipedes sat lati, lamellis internis sat elongatis. Mandibulæx acie denticulatâ instruetæe et alterâ aceessoriâ quoque proeessu molari et palpo 3 -articulato. Pedes 10 postiei non subprehénsiles.-G. Acanthonotus, Owcn, Alibrotus, E., Leptochirus, Zad., Iphimedia, Rath., D., Edicerus, Kr., Amphithoe, Lh., D., Gammarus, Fab., D., Photis, Kr., 
Melita, Lh., D., Msera, Lb., D., Dercothoe, D., Pyctilus, D., Atylus, Lh., Ischyrocerus, Kr. [An hujus sedis Pardatisca, Kr. ?]

\section{Pedes 10 postici partim prehensiles.}

5. Pontoporeins.-Pedes 3 tii 4 tique plus minusve prchensiles; 6 postici non prehensiles.-G. Lepidactylis, Say, Pontiporeia, Kr., Ampelisca, Kr., Proto. medeia, Kr., Aora, Kr., Phoxus, Kr.

6. Is_ein ze.-Pedes 4 vel 6 postici subprehcnsiles.-G. Isæa, E., Anisopus, Tem.

\section{SUBtribUs III. HYPERIDEA.}

Maxillipedes abbreviati, lamellati, operculiformes. Caput grande, oculorum corneis plerumque tectum. Appendices abdominales ac in Gammarideis, latius lamellatæ.

Fam. I. HYPERIDA.-Antennx 2 dx exsertæ. Abdomen in ventrem se non flectens. Pedes 5ti 6ti 7 mique formâ longitudineque mediocres, 5 tis 6 tisve non percrassis nec prehensilibus.

1. Vibilins. -Corpus formâ paulo Gammaroidcum. Caput oculique mediocres. Maxillipedes palpo parvulo instructi. Palpus mandibularis tenuis.-G. Vibilia, $\mathbf{E}$.

2. Hyperinze.-Caput tumidum. Oculi pergrandes. Palpus mandibularis tenuis. -G. Lestrigonus, E., Tyro, E., Hyperia, Lat.; Metoecus, Kr., Tauria, D., Dairinia, D. (=Daira, Edw.), Cystisoma, Gucr.

3. Srnopinse.-Corpus gracilius. Palpus mandibularis sat brevis, latissimus. Oculi grandes.-G. Synopia, D.

Fam. II. PHRONIMIDA.-Antennæ 2 dæ exsertæ. Abdomen in ventrem se non flectens. Pedes 5ti 6tive sive crassi sive elongati, sæpius prehensiles, quoque 3 tii 4 tique sæpe prehensiles.

1. Phroniminze.-Abdomen versus basin sat gracile. Pedes 5 ti magnâ manu didactylâ vel monodactylâ confecti; 3 tii 4 ti extremitate graciles, non prehcnsiles. Antennæ breves. G. Phronima, Lat., Primno, Guer.

2. Phrosininse.-Abdomen rersus basin sat crassum. Pedes 5 ti prehensiles, monodactyli; quoque 3 tii 4 tique prchensiles.-G. Anchylomera, E., Phrosina, Risso, Themisto, Guer.

3. Prorcinde.-Pedes 5ti 6tive valde clongati, et crassi, sed manu non confecti.G. Phorcus, E.

Fam. III. TYPHID $\mathrm{E} .-\Lambda$ ntennæ 2 dæ sub capite thoraceve cclatæ et sæpius replicatæ. $\Lambda$ bdomen in ventrem sæpe se flectens. Pedes 
6 postici interdum abbreviati cum articulo 1 mo operculiformi, interdum longitudine mediocres.

1. Trrinsa.-Abdomen in ventrem se flectens.-G. Dithyrus, D., Typhis, R. Thyropus, D.

2. Pronorns.-Abdomen in ventrem se non fleetens. Caput non oblongum, antennis in eapitis frontem insitis.-G. Pronoe, Guer., Lycæa, D.

3. OxyCEPHALINAs.-Abdomen in ventrem se non fleetens. Caput oblongum antennis $1 \mathrm{mis}$ in superfeiem eapitis inferiorem insitis.-G. Oxycephalus, E. Rhabdosoma, W.

ORDO II. (?) TRILOBITA.

\section{Subchassis III. ENTOMOSTRACA.}

\section{ORdo I. GNATHOSTOMATA.}

\section{LEGIO I. LOPHYROPODA.}

\section{Tribus I. CYCLOPOIDEA.}

Fam. I. CALANIDAE.-Oculi duo simplices minutissimi, pigmentis sive coalitis sive discretis; interdum oculi alii in uno coaliti infra caput deorsum spectantes. Mandibulæe maxillæque elongati palpigeræ. Pedes Imi nunquam prehensiles.

1. Caraninat-Oeuli inferiores nulli. Antennæ $1 \mathrm{~m} \circledast$ longæe, fere transversim porreetæ; dextra maris articulatione non genieulans; 2 dæ non prehensiles. Maxillæ latere interiore setigeræo. Abdomen longitudine medioere.-G. Calanus, Leaeh, Rhincalanus, D., Cetochilus, Euchrta, Philippi, Undina, D.

2. Pontellinke.-Oeuli inferiores distineti. Antennæ 1mæ longæ sæpe oblique porrectx; dextra maris artieulatione sxpius genieulans; 2 dæo non prehensiles. Maxillæ abdomenque ae in Calaninis. G. Hemicalanus, D., Diaptomus, Westw., Candace, D., Pontella, Acartia D., Catopia, D.

3. Orthoninss.-Oeuli et antennæx fere ae in Calaninis. Abdomen prælongum, eephalothoraee vix brevius. Maxillo latere interiore digitatæ.-G. Oithona, Baird.

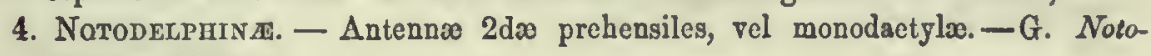
delphys, Allman. 
Fam. II. CYCLOPIDÆ.-Oculi duo simplices minutissimi coaliti tantum. Mandibulæo palpo parvulo vel obsoleto. Pedes 1mi plus minusve subprehensiles.

1. CrcLopres.-Sacculi origeri externi duo.-G. Cyclops.

2. Harpacticines.-Sacculus oviger unicus.-G. Harpacticus, Edw., Clytemnestra, D., Canthocamptus, Westw., Setella, D.

Fam. III. CORYCAIDA.-Oculi duo simplices minutissimi coaliti; quoque alii duo portentosæ magnitudinis, lenticulo prolato interno corneâque magnâ oblatâ in testam insitâ instructi. Sacculi ovigeri sive duo sive unicus. Pedes $1 \mathrm{mi}$ sæpius subprehensiles.

1. Coryceine.-Sacculi ovigeri duo.-G. Corycous, D., Antaria, D., Sapphirina, Thompson.

2. Miracin Æ.-Sacculus ovigerus unicus.-G. Miracia, D.

\section{TRIBUS II. DAPHNIOIDEA.}

Fam. I. PENILID A.-Pedes foliacei numero duodecim, angustiores. Antennæ anticæ obsolescentes.

G. Sida, Straus, Daphnella, Baird, Penilia, D., Latona, Str.

Fam. II. DAPHNIDA. - Pedes foliacei numero decem, latiores. Antennæe anticæ 1-2-articulatæ, raro multiarticulatæ.

G. Daphnia, M., Ceriodaphnia, D., Moina, Baird, Macrothrix, B., Acanthocercus, Schödler, Eurycercus, B., Lynceus, M., Alona, Baird, Bosmina, Baird.

Fam. III. POLYPHEMID Æ.-Caput grande, oculis repletum. Pèdes numero octo, fere teretes. Antennæ anticæ obsolescentes.

G. Polyphemus, M., Evadne, Loven, Pleopis, D.

Tribus III. CYPROIDEA.

Fam. I. CYPRID E. - Antennæ 2dæ subteretes, 3-5-articulatæ. Mandibulæ apice productæ et denticulatæ, et lateraliter palpigeræ, palpo a mandibulæ apice remoto. Oculi pigmento unico minuto conjuncti, lenticulis duobus sphericis. Pedes duo vel plures tenuiter pediformes. 
1. Cyprins.-Pedes numero quatuor; anteriores tenues pediformes, posteriores debiles. Abdomen elongatum, stylis duobus confectum.-G. Cypris, Müller, Candona, Baird.

2. Сytherinæ.-Pedes numero sex, consimiles, pediformes. Abdomen brevo.-G. Cythere, Müller.

Fam. II. HALOCYPRIDAs.-Antennæ 2dæ basi crass $x$, sæpius birameæ, ramo longiore 5-7-articulato elongatè setigero. Appendices mandibulares omnino pediformes, processu molari parvo.

1. Cxpridininse.-Pedes quatuor, articulati. Maxillæ quatuor.-G. Cypridina, E.

2. Halocyprina.-Pedes duo, vermiformes. Maxillo sex.-G. Halocypris, D., Conchoecia, D.

\section{LEGIO II. PHYLLOPODA.}

\section{Tribus I. ARTEMIOIDEA.}

Fam. I. ARTEMIAD Æ.-Cephalothorax multiannulatus usque ad caput, testâ nusquam tectus. Pedes numerosi, foliacei.

1. Chirocephaline.-Corpus gracile. Abdomen longum et multiarticulatum. Antennæ $2 \mathrm{~d} æ$ breves sed pererassæ, maris prehensiles.-G. Chirocephalus, Prevost, Artemia, Leach.

2. Eulimeninæ.-Abdomen fere obsoletum. Antennæ quatuor fere filiformes.G. Eulimene, Lat.

Fam. II. NEBALIADA.-Cephalothorax testâ fere bivalvi bene tectus. Abdomen non inflexum, pauci-annulatum. Pedes plures posteriores biremes, ac in Cyclopoideis, reliqui anteriores foliacei, branchiales.

G. Nebalia, Leach.

TRIBUS II. APODOIDEA.

Fam. APODID $A$.-Oculi duo compositi. Appendices duæ caudales rigidè setiformes. Testa scutiformis.

G. Apus, Schoefer. 
Tribus III. LIMNADIOIDEA.

Fam. LIMNADIDAE.

G. Limnadia, Br., Cyzicus, Aud., Limnetis, Loven (Hedessa, Lievin).

\section{ORDO II. CORMOSTOMATA.}

SUBORdo I. PEECILOPODA.

TrIBUS I. ERGASILOIDEA.

Fam. I. MONSTRILLID E.-Corpus elongatum fere cylindricum. Abdomen 5-6-articulatum, segmentis 1mo 2doque appendicibus setosis munitis ac in Setella. Maxillæ, antennæo posticæ et pedes antici obsoleti, pedes octo maxime biremes.

G. Monstrilla, D.

Fam. II. ERGASILID无. - Corpus breviusculum, cephalothorace crasso, abdomine stylis caudalibus minutis setigeris confecto. Antennæ posticæ subprehensiles ac in Corycaco, pedes octo postici bene biremes.

G. Ergasilus, Nordmann.

Fam. III. NICOTHOID $A$.-Ergasilidis affinis. Antennæ posticæ perbreves vel rudimentariæ. [Corpus lobis tumidis prodigiosis lateraliter prolongatum.]

G. Nicothoe, Aud. et Edw.-[Cujus sedis est Bomolocus, Nordmann ?]

\section{Tribus II. CALIGOIDEA.}

Fam. I. ARGULID $\nexists$ E.-Corpus late depressum, peltatum. Antennæe $1 \mathrm{~m}$ obsoletæ. Pedes $1 \mathrm{mi}$ tubulati, 2di unguiculati. Ova in tubis vel sacculis externis non gesta.

G. Argulus, Müiller.

Fam. II. CALIGID AE.-Corpus late depressum, peltatum, segmento 
antico pergrandi. Antennæ $1 \mathrm{~m} x$ breves, 2-3-articulatx; 2dx corpore tectx. Pedes $1 \mathrm{mi}$ graciles, 2 di prehensiles vel ancorales. Ova externa in tubis gesta.

1. Caligin z.-Truncus bueealis ovoideus, paulo oblongus, aperturâ oris inferiore. Maxillæ ab ore remotæ, brevissimæ, crass $\infty$. Tubi ovigeri externi reeti. Antennæ anticæ 2-articulatæ.-G. Caligus, Müller, Lepeophtheirus, Nord., Cali. geria, D., Calistes, D., Trebius, Kr.

2. Pandarinds.-Truneus buccalis acuminatus, aperturâ terminali. Maxilloo parvula lamellares ad truncum appressao. Tubi ovigeri externi recti.-G. Pandarus. Lh., Nogagus, Lh., Phyllophora, E., Dinemalura, Lat., Euryhporus, Nord., Lepidopus, D.

3. Cecropinds.-Pandarinis affnes. Tubi ovigeri externi sub abdomine convoluti.-G. Cecrops, Læmargus.

4. Specilliarna.-Pandarinis affines. Oculi duo ac in Sapphirinis. G. Specitligus, $\mathbf{D}$.

Fam. III. DICHELESTID $\mathrm{E}$.-Corpus angustum, segmento antico parvo. Antennæ 1mæ breves, 5-10-articulatæ; 2 dæ fere frontales, ultra caput exsertæ. Pedes 1mi graciles, 2di prehensiles. Ova externa in tubis gesta.

1. Diohelestinæ.-Segmenta corporis angusta, non foliosè producta.-G. Dicheles. iium, Herm., Nemesis, Roux.

2. Anthosomatina.-Segmenta corporis foliosè producta.-G. Anthosoma, Leach.

Tribus III. LERN AEOIDEA.

Fam. I. CHONDRACANTHIDAE. - Appendices cephalothoracis numero quatuor vel plures, unguibus plus minusve ancorales.

1. Selin a.-Antennæ antice et pedes thoracis postici graciles.-G. Selius, Kr.

2. Chondracanthinss.-Antennæ anticæ graciles vel perbreves. Pedes thoracis postiei breviter et erasse ancorales.-G. Chondracanthus, de la Roche, Lernanthropus, Bl., Lernentoma, Bl., Cycnus, E.

3. Cuaveluin x.-Antennæ antieæ obsoletæ. Pedes thoracis postici crassi et breves.-G. Clavella, Oken, Peniculus, Nord., Ethon, Kr.

Fam. II. ANCORELLID $\approx$ E.-Antennæ postic sæpeque per latera connatæ et disco ancorali confectæ.

1. Anconelinds.-Antenno postic femiuarum per latera connatæo et disco ancorali confecta.-G. Ancorella, Cuv.

2. Lernaopodins.-Antennæ postic feminarunı versus apicem connatæ tantum. -G. Lernzeopoda, Kr., Brachiella, Cuv., Achtheres, N., Tracheliastes, N., Basanístes, $\mathrm{N}$. 
Fam. III. PENELLID A.-Pedes obsoleti. Caput 2-4 appendicibus brevibus non articulatis munitum.

1. Penelines.-Pedes pauci rudimentarii vix obsoleti.-G. Penella, Oken, Lerneonema, Edw.

2. Lerneocerin w.-Pedes omnino obsoleti.-G. Lerneocera, Bl., Lernea.

Subordo II. ARACHNOPODA Vel PYCNOGONOIDEA.

Fam. I. NYMPHID A.-Antennis munitæ.

G. Nymphum, Fabr., Ammothea, Lh., Pallene, J., Phoxichilidium, J.

Fam. II. PYCNOGONID A.-Antennis carentes.

G. Pycnogonum, Brunnich, Phoxichilus, Lat.

SubCLASSIS IV. CIRRIPEDIA.

Subclassis V. ROTATORIA.

\section{A P P E N D I X.}

'TuE following references are here added to genera of Fossil Crustacea, not mentioned in the preceding classification, excluding the Trilobite group.

1. Xanthid A.-Arges of De Haan (Faun. Japon., 21 and 52, pl. 5, 
f. 4), a genus near Pilumnus and Menippe. Maxillipeds Cancroid, abdomen in both sexes seven-jointed; lateral margins of carapax parallel and entire, so as to resemble Cyclograpsus Audouinii. Distance between the eyes one-fifth the breadth of the thorax.

Etyoed, Leach (Mantell's Geol. of Sussex, Pl. 29, f. 11, 12), has the transverse form of Xantlio.

2. ERIPHIDs (?)-Zanthopsis, M'Coy (Ann. Mag. N. H. [2], iv. 162), approaches Actumnus in nearly orbicular outline and convexity of carapax, but has the fingers acuminated; the basal joint of the outer antennæ just reaches the front.

Podopitumnus, M'Coy (loc. cit., p. 165), very near Galene of De Haan. It has the slender legs of our Pilumnus tenellus.

3. Anomoura.-Dromilites and Ogydromites of Edwards; Hela of Count Münster; Basinotopus and Notopocorystes of M'Coy (Ann. Mag. N. H. [2], iv. 167, 169). The form and sutures of the carapax, in M'Coy's genera, and the character of the arms and of the posterior legs, are very nearly as in Eglea.

4. Thalassinidea.-Magila, Aura, Cancrinos, Orphnea, Brisa, and Brome of Münster; Megachirus and Pterochirus of Brown.

5. Astaciden.-Coleia, Broderip (Geol. Trans. [2], v.); Glyphea and Pemphix, von Meyer (Foss. Krebse); Bolina, Münster; Podocratus, Becks; Archococarabus and Hoploparia of M'Coy (Ann. Mag. N. H. [2], iv. 173, 175). The species have the transverse suture across the carapax, which distinguishes the Astacidea and most Thalassinidea from the Caridea and Penæidea.

6. Pen widea.-The following genera are referred to the Penæus group by De Haan (Faun. Japon., 187): Antrimpos, Bylgia, Drobna, Dusa, Blaculla, AEger, Udora, Kolga, Hefriga, Elder of Count Münster, and possibly, Rauna and Bombur of the same author. In the first seven of these genera all the legs are didactyle, and in Hefriga and Elder all are monodactyle. The genus Saga of Count Münster, De Haan refers to the Mysidea. 
7. SquilloideA.-Naranda and Reckur of Count Münster are referred here by H. G. Bronn (Index Palæontologicus, ii. 575); and also, with a query, Norna and Urda of the same author.

8. Isopoda.-Archooniscus and Palaconiscus of Edwards (Ann. des Sci. Nat., xx. 326). Archæoniscus, according to Edwards, is between Spheroma and Ancinus.

9. Entomostraca.-T. Rupert Jones adds to the Cytherinos the genera (or "subgenera") Cytherella and $C y$ thereis, bascd on the form of the shell. Cyprella and Cypridella of Koninck (Descript. An. Foss.) are genera proposed for Cyproid species found in the Belgian carboniferous beds; and Dithyrocaris, Scouler (Portlock's Geol. Rep., Londonderry, and Wm. King's Permian Fossils of England, p. 64, Palæontograph. Soc., Pub. 1850), includes Carboniferous or Permian specics, which have been referred both to the Cyproidea and Apodoidea, it being uncertain whether the shell is properly bivalve or not. Cytheropsis, M'Coy, includes Palæozoic species that have been referred to Cytherina; Beyrichia and Ceratiocaris, M'Coy (Brit. Pal. Fossils, Mus. Camb., 4to, 1851, 135), are genera of other Palæozoic specics. All the carboniferous and Palæozoic species are referred to the section Phyllopoda, near the bivalve genus Limnadia, by Burmeister and M'Coy. The abnormal number of segments in other Palæozoic Crustacea render it probable that this reference of them is right.

Entomoconchus, M'Coy (Jour. Geol. Soc. Dublin, ii.), and Daphnoidea, Hibbert (On the Burdie House Limestone, Trans. Roy. Soc. Edinb., xiii. 180), are other related genera. The lattcr may be near A pus.

Eurypterus, Harlan, and Pterygotus, M'Coy, are other Palæozoic genera, probably of Entomostraca. Eurypterus has been supposed to be related to Limulus.

Belinurus, Köninck, Halicyne, von Meyer, are other genera, refcrred to the Pocilopoda. 


\title{
GEOGRAPHICAL DISTRIBUTION
}

\author{
C R U S T A C E A.
}

\section{PRELIMINARY CONSIDERATIONS ON THE TEMPERATURE}

OF THE OCEANS.

ThE temperature of the waters is well known to be one of the most influential causes limiting the distribution of marine species of life. Before therefore we can inake any intelligent comparison of the Crustacea of different regions, it is necessary to have some clear idea of the distribution of temperature in the surface waters of the several oceans; and, if we could add also, the results of observations at various depths beneath the surface, it would enable us still more perfectly to comprehend the subject. The surface temperature has of late years been quite extensively ascertained, and the lines of equal temperature may be drawn with considerable accuracy. But in the latter branch of thermometric investigation almost everything yet remains to be done: there are scattering observations, but none of a systematic character, followed through each season of the year.

The Map which we have introduced in illustration of this subject, presents a series of lines of equal surface temperature of the oceans. The lines are isocheimal lines, or, more properly, isocrymal lines; and where they pass, each exhibits the mean temperature of the waters along its course for the coldest thirty consecutive days of the year. 
The line for $68^{\circ} \mathrm{F}$., for example, passes through the ocean where $68^{\circ}$ F., is the moan temperature for extreme cold weather. January is not always the coldest winter month in this climate, neither is the winter the coldest season in all parts of the globe, espeeially near the equator. On this account, we do not restriet the lines to a given month, but make them more correctly the limit of the extreme eold for the year at the place.* Between the line of $74^{\circ}$ north and $74^{\circ}$ south of the equator, the waters do not fall for any one month below $74^{\circ} \mathrm{F}$.; between $68^{\circ}$ north and south, they do not fall below $68^{\circ}$.

There are several reasons why isocrymal are preferable to summer or isotheral lines. The cause which limits the distribution of species northward or southward from the equator is the cold of winter, rather than the heat of summer, or even the mean temperature of the year. The mean temperature may be the same when the extremes are very widely different. When these extremes are little remote, the equable character of the seasons, and especially the mildness of the winter temperature, will favour the growth of speeies that would be altogether cut off by the cold winters where the extremes are more intense. On this account, lines of the greatest cold are highly important for a chart illustrating the geographieal distributions of species, whether of plants or animals. At the same time, summer lines have their value. But this is true more particularly for species of the land, and fresh-water streams, and sea-shore plants. When the summer of a continent is excessive in its warmth, as in North America, many species extend far from the tropics that would otherwise be confined within lower latitudes. But in the ocean, the extremest cold in the waters, even in the Polar regions, wherever they are not solid ice (and only in such places are marine species found), is but a few degrees below $32^{\circ}$ Fahrenheit. The whole range of temperature for a given region is consequently small. The region which has $68^{\circ}$ F. for its winter temperaturc, has about $80^{\circ}$ for the hottest month of summer; and the line of $56^{\circ} \mathrm{F}$. in the Atlantic, which has the latitudes of the state of New York, follows the same course nearly as the

* The word isocrymal here introduced is from the Greek wos, equal, and xevuos, extreme cold, and applies with sufficient precision to the line for which it is used. These lines are not isocheimal lines, as these follow the mean winter temperaturc; and to use this term in the case before us, would be giving the word a signification which does not belong to it, and making confusion in the science. 
summer line of $70^{\circ} \mathrm{F}$. In each of these cases the whole extent of the range is small, being twelve to fourteen degrees.*

In fresh-water streams, the waters, where not frozen, do not sink lower than in the colder oceans, reaching at most but a few degrees below freezing. Yet the extremes are greater than for the ocean; for in the same latitudes which give for the ocean $56^{\circ}$ and $70^{\circ} \mathrm{F}$. as the limits, the land streams of America range in temperature between $30^{\circ}$ and $80^{\circ} \mathrm{F}$., and the summer warmth in such a case, may admit of the development of speeies that would otherwise be excluded from the region.

While then both isocrymal and isothermal lines are of importance on charts illustrating distribution over the continents, the former are pre-eminently important where the geography of marine species is to be studied.

The lines of greatest cold are preferable for marine speeies to those of summer heat, also because of the fact that the summer range for $30^{\circ}$ of latitude either side of the equator is exceedingly small, being but three to four degrees in the Atlantic, and six to eight degrees in the Pacific. The July isothermal for $80^{\circ} \mathrm{F}$. passes near the parallel of $30^{\circ}$; and the extreme heat of the equatorial part of the Atlantic Oeean is rarely above $84^{\circ}$. The difficulty of dividing this space by convenient isothermals with so small a range is obvious.

It is also an objection to using the isotheres, that those towards the equator are much more irregular in eourse than the isocrymes. That of $80^{\circ}$ for July, for example, which is given on our Map from Maury's Chart, has a very flexuous course. Moreover, the spaces between the isotheres fail to eorrespond as well with aetual facts in geographical distribution. The eourses of the cold water currents are less evident on such a chart, since the warm waters in summer to a great extent overlie the eolder eurrents.

It is also to be noted that nothing would be gained by making the mean temperature for the year, instead of the extremes, the basis for laying down these lines, as will be inferred from the remarks already made, and from an examination of the ehart itself.

The distribution of marine life is a subject of far greater simplieity

* Moreover, the greatest range for all oceans is but $62^{\circ}$ of Fahreaheit, the highest being $88^{\circ}$, and the lowest $26^{\circ}$; while the temperature of the atmosphere of the globe has a range exceeding $150^{\circ}$. 
than that of continental life. Besides the influence on the latter of summer temperature in eonnexion with that of the eold seasons, already alluded to, the following elements or eonditions have to be considered:-the eharacter of the climate, whether wet or dry; - of the surface of the region, whether sandy, fertile, marshy, ete.;-of the vegetation, whether that of dense forests, or open pasture-land, ete. ;of the level of the eountry, whether low, or elevated, ete. These and many other eonsiderations come in, to influence the distribution of land species, and lead to a subdivision of the Regions into many subordinate Distriets. In oeeanie produetions, depth and kind of bottom have an important bearing: but there is no oeeasion to consider the moisture or dryncss of the elimate; and the influenee of the other peculiarities of region mentioned is much less potent than with eontinental life.

We would add here, that the data for the construction of this chart have been gathered, as regards the North Atlantie, from the isothermal ehart of Lieutenant Maury, in which a vast amount of facts are registered, the result of great labour and study. For the rest of the Atlantic and the other oeeans we have employed the Meteorological volumc of Captain Wilkes of the Exploring Expcdition Reports, which embraees observations in all the oceans and valuable deductions therefrom; also, the reeords of other travellers, as Humboldt, Duperrey of the Coquille, D'Urville of the Astrolabe, Kotzebue, Beechey, Fitzroy, Vaillant of the Bonite, Ross in his Antaretic Voyage, together with sueh isolated tables as have bcen met with in different Journals. The lines we have laid down, are not however, those of any chart previously eonstructed, for the rcason stated, that they mark the positions where a given temperature is the mean of the eoldest month (or coldest thirty eonsceutive days) of the year, instead of those where this temperature is the mean annual or montlly heat; and hence, the apparent discrepancies, which may be observed, on comparing it with isothermal charts.

The isocrymal lines adopted for the chart arc those of $80^{\circ}, 74^{\circ}$, $68^{\circ}, 62^{\circ}, 56^{\circ}, 50^{\circ}, 44^{\circ}$, and $35^{\circ}$ of Fahrenheit. They diminish by $6^{\circ}$, excepting the last, whieh is $9^{\circ}$ less than $44^{\circ}$.

In adopting these lines in preference to those of other degrees of tempcrature, we have been guided, in the first placc, by the grcat faet, that the isocryme of $68^{\circ}$ is the boundary line of the coral-reef seas, as 
explained by the author in his Report on Zoophytes.* Bcyond this line either side of the equator, we have no species of true Madrepora, Astræa, Meandrina or Porites; below this line, these corals abound and form extensive rcefs. This line is hence an important starting point in any map illustrating the geography of marine life. Passing beyond the regions of coral recfs, we lcave behind large numbers of Mollusca and Radiata, and the boundary marks an abrupt transition in zoological geography.

The next line below that of $68^{\circ} \mathrm{F}$, is that of $74^{\circ} \mathrm{F}$. The corals of the Hawaiian Islands, and the Mollusca also to a considerable extent, differ somewhat strikingly from those of the Fecjces. The species of Astræa and Meandrina are fewer, and those of Porites and Pocillopora more abundant, or at least constitute a much larger proportion of the reef material. These genera of corals include the hardier species; for wherc they occur in the equatorial regions they are found to experience the greatest range in the condition of purity of the waters, and also the longest exposures out of water. Their abundance at the Hawaiian Islands, as at Oahu, is hence a consequencc of their hardier character, and not a mere region peculiarity independent of tempcrature. There are grounds, therefore, for drawing a line between the Hawaiian Islands and the Feejees; and as the temperature at the latter sinks to $741^{\circ}$. F. some parts of the year, $74^{\circ}$ $\mathrm{F}$. is taken as the limiting temperature. The Feejec seas are exceedingly prolific and varied in tropical species. The corals grow in grcat luxuriance, exceeding in extent and beauty anything elsewhere observed by the writer in the tropics. The ocean between $74^{\circ} \mathrm{F}$, north of the equator, and $74^{\circ} \mathrm{F}$. south, is therefore the proper tropical or torrid region of zoological life.

With respect to the line of $80^{\circ} \mathrm{F}$, we are not satisfied that it is of much importance as regards the distribution of species. The range from the hottest waters of the ocean $88^{\circ}$ to $74^{\circ} \mathrm{F}$. is but fourtcen degrees, and therc are probably few species occurring within the region that demand a less range. Still, investigations hereafter madc, may show that the hot waters limited by the isocryme of $80^{\circ}$ includes some peculiar species. At Sydney Island and Fakano, within this hot area, there appeared to be among corals a rather greater prevalence than usual of the genus Manopora, which as these are tender

* In the author's Report on Geology, $66^{\circ} \mathrm{F}$. is set down as the limiting temperature of Coral-reef Seas : this, however, is given as the exireme cold. $68^{\circ}$ appears to be the mean of the coldest month, and is therefore here used. 
species, may perhaps show that the waters are less favourable for hardier corals than those of the Feejees, where the range of temperature is from $74^{\circ}$ to $80^{\circ} \mathrm{F}$; but this would be a hasty conclusion, without more extended observations. The author was on these islands only for a few hours, and his collections were afterwards lost at the wreck of the Peacock, just as the vessel was terminating the voyage by entering the Columbia River.

It is unnecessary to remark particularly upon the fitness of the other isocrymals for the purposes of illustrating the geographical distribution of marine species, as this will become apparent from the explanations on the following pages.

The regions thus bounded require, for convenience of designation, separate names, and the following are therefore proposed. They constitute three larger groups : the first, the Torrid zone or Coral-reef seas, including all below the isocryme of $68^{\circ} \mathrm{F}$; the second, the Temperate zone of the oceans, or the surface between the isocrymes of $68^{\circ} \mathrm{F}$. and $35^{\circ} \mathrm{F}$.; the third, the Frigid zone, or the waters beyond the isocryme of $35^{\circ} \mathrm{F}$.

I. TORRID OR CORAL-REEF ZONE.

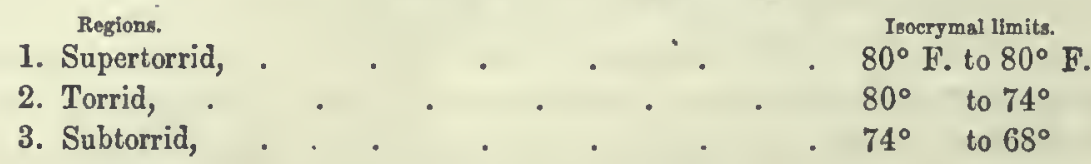

II. TEMPERATE ZONE.

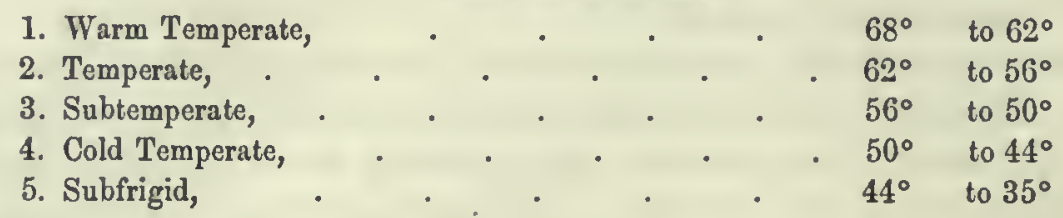

III. FRIGID ZONE.

1. Frigid, . . . . $35^{\circ}$ to $26^{\circ}$

A ninth region-called the Polar-may be added, if it should be found that the distribution of species living in the Frigid zone requires it. There are organisms that occur in the ice and snow itself 
of the polar regions; but these should be classed with the animals of the continents; and the eontinental isotherms or isocrymes, rather than the oceanic, are required for elueidating their distribution.

It seems necessary to state here the authorities for some of the more important positions in these lines, and we therefore run over the observations, mentioning a few of most interest. There is less neeessity for nuany particulars with reference to the North Atlantie, as our facts are mainly derived from Lieut. Maury's Chart, to which the author would refer his readers.

1. Nontil Atlantic.-Isocryme of $74^{\circ} \mathrm{F}$.-This isoeryme passes near the reefs of Key West, and terminates at the northeast cape of $\mathrm{Yu}$ eatan; it rises into a narrow flexure parallel with Florida along the Gulf Stream, and then continues on between the Little and Great Bahamas. To the eastward, near the African eoast, it has a flexure northward, arising from the hot waters along the eoast of Guinea, which reach in a slight current upward towards the Cape Verde Islands. The line passes to the south of these islands, at which group, Fitzroy, in January of 1852 , found the sea-temperatures $71^{\circ}$ and $72^{\circ} \mathrm{F}$.

Isocryme of $68^{\circ} \mathrm{F}$.-Cape Canaveral, in latitude $27^{\circ} 30^{\prime}$, just north of the limit of coral reefs on the east coast of Florida, is the western termination of the line of $68^{\circ}$. The Gulf Stream ocensions a bend in this line to $36^{\circ}$ north, and the polar current, east of it, throws it southward again as far as $29^{\circ}$ nortl. Westward it inclines much to the south, and terminates just south of Cape Verde, the eastern eape of Afriea. Sabine found a temperature of $64^{\circ}$ to $65^{\circ} \mathrm{F}$. off Goree, below Cape Verde, January, 1822; and on February 9, 1822, he obtained $66 \frac{1}{2}^{\circ}$ near the Bissao shoals. These temperatures of the eold season contrast strikingly with those of the warm season. Even in May (1831), Becchey had a temperature of $86^{\circ}$ off the mouth of Rio Grande, between the parallels of $11^{\circ}$ and $12^{\circ}$ north.

Isocryme of $62^{\circ} \mathrm{F}$.-This isocryme leaves the Ameriean eoast at Cape Hatteras, in latitude $35^{\frac{1}{2}} \mathrm{O}$ north, where a bend in the outline of the continent prevents the southward extension of the polar eurrents from flowing close along the shores. It passes near Madeira, and bends southward reaching $A$ frica nearly in the latitude of the Canaries.

Isocrymes of $56^{\circ}$ and $50^{\circ} \mathrm{F}$-Cape Hatteras, for a like reason, is the limit of the isocrymes of $56^{\circ}$ and $50^{\circ}$ as well as of $62^{\circ}$, there being 
no interval between them on the American coast. The line of $56^{\circ}$ F. has a deep northward flexure between the meridians of $35^{\circ}$ and $40^{\circ}$ west; arising from the waters of the Gulf Stream, which here (after a previous east and west course, occasioned by the Newfoundland Bank, and the Polar Current with its icebergs) bends again northeastward, besides continuing in part eastward. The Polar Current sometimes causes a narrow reversed flexure, just to the east of the Gulf Stream flexure. Towards Europe, the line bends southward, and passes to the southwest cape of Portugal, Cape St. Vincent, or, perhaps to the north cape of the Straits of Gibraltar. Vaillant, in the Bonite, found the temperature at Cadiz in February, $49 \frac{1}{2}^{\circ}$ to $56^{\circ} \mathrm{F}$. $\left(9 \cdot 7^{\circ}\right.$ to $13 \cdot 4^{\circ} \mathrm{C}$.), which would indicate that Cadiz, although so far sonth (and within sixty miles of Gibraltar), experiences at least as low a mean temperature as $56^{\circ} \mathrm{F}$. for a month or more of the winter season. We have, however, drawn the line to Cape St. Vincent, which is in nearly the same latitude. Between Toulon and Cadiz, the temperature of the Mediterranean in February, according to Vaillant, was $55 \frac{1}{2}^{\circ}$ to $601^{\circ} \mathrm{F} .\left(13 \cdot 1^{\circ}\right.$ to $15 \cdot 7^{\circ} \mathrm{C}$.), and it is probable, therefore, that Gibraltar and the portion of the Mediterranean Sea east and north to Marseilles, fall within the Temperate Region, between the isocrymcs of $56^{\circ}$ and $62^{\circ} \mathrm{F}$., while the portion beyond Sardinia and the coast by Algiers is in the Warm Temperate Region, betwecn the isocrymes of $62^{\circ}$ and $68^{\circ} \mathrm{F}$.

The line of $50^{\circ} \mathrm{F}$., through the middle of the ocean, has the latitude nearly of the southern cape at the entrance of the British Channel; but approaching Europe it bends downward to the coast of Portugal. The low temperature of $49 \frac{1}{2}^{\circ}$ observed by Vaillant at Cadiz would carry it almost to this port, if this were the mean seatemperature of a month, instcad of an extreme within the bay. The line appears to terminate near latitude $42^{\circ}$, or six degrees north of the isocryme of $56^{\circ}$. This allows for a diminution of a degree Fahrenheit of temperature for a degrec of latitude. A temperaturc as low as $61^{\circ}$ F. has been observed at several points within five degrees of this coast in July, and a temperature of $52^{\circ} \mathrm{F}$., in February. Vigo Bay, just north of $42^{\circ}$ north, lies with its entrance opening westward, well calculated to receive the colder waters from the north; and at this place, according to Mr. R. Mac Andrew, who made several dredgings with reference to the geographical distribution of species, the Mollusca 
have the character rather of those of the British Channel than of the Mediterranean.

Isocryme of $44^{\circ} \mathrm{F} .-$ This line commences on the west, at Cape Cod, where there is a remarkable transition in species, and a natural boundary between the south and the north. The cold waters from the north and the iee of the Newfoundland Banks, press the line close upon those of $50^{\circ}$ and $56^{\circ} \mathrm{F}$. But after getting beyond these influenees, it rapidly rises to the north, owing to the expansion of the Gulf Stream in that direction, and forms a large fold between Britain and Ieeland; it then bends south again and curves around to the west coast of Ireland.

Isocryme of $35^{\circ} \mathrm{F}$.- This line has a bend between Norway and Iceland like that of $44^{\circ}$, and from the same cause,- the influenee of the Gulf Stream. But its exact position in this part has not been aseertained.

2. South Atlantic.-Isocryme of $74^{\circ}$ F.-This line begins just south of Bahia, where Fitzroy found in August (the last winter month) a temperature of $74^{\circ}$ to $752^{\circ} \mathrm{F}$. During the same month he had $75 \frac{1}{2}^{\circ}$ to $76 \frac{1}{2}^{\circ} \mathrm{F}$. at Pernambueo, five degrees to the north. Off Bahia, the temperature was two degrees warmer than near the coast, owing to the warm tropical current, whieh bends the isocryme south to latitude $17^{\circ}$ and $18^{\circ}$, and the cold waters that come up the coast from the south. The line gradually rises northward, as it goes west, and passes the equator on the meridian of Greenwich. Sabine, in a route nearly straight from Ascension Island, in $8^{\circ}$ south, to the African eoast under the equator, obtained in June (not the coldest winter month) the temperatures $78^{\circ}, 77^{\circ}, 74^{\circ}, 72.8^{\circ}, 72.5^{\circ}, 73^{\circ}$, the temperature thus diminishing on approaehing the eoast, although at the same time nearing the equator, and finally reaching it within a few miles. These observations in June show that the isocryme of $74^{\circ} \mathrm{F}$. passes north of the equator. The temperatures mentioned in Maury's Chart afford the same eonelusion, and lead to its position as laid down.

Isocryme of $68^{\circ} \mathrm{F}$.-On October $23 \mathrm{~d}$ to $25 \mathrm{th}, 1834, \mathrm{Mr}$. D. J. Browne, on board the U. S. Ship Erie, found the temperature of the sea on entering the harbour of Rio Janeiro, $67 \frac{1}{2}^{\circ}$ to $682^{\circ} \mathrm{F}$. Fitzroy, on July 6, left the harbour with the sea-temperature $70 z^{\circ} \mathrm{F}$. Beeehey, in August, 1825 , obtained the temperatures $68 \cdot 16^{\circ}$ to $69 \cdot 66^{\circ} \mathrm{F}$. off the liarbour. The isocryme of $68^{\circ} \mathrm{F}$. commenees therefure near Rio, not far south of this harbour. Eastward of the harbour, the tem- 
perature increases two to four degrees. In July, Fitzroy carried a temperature above $68^{\circ}$ as far south as $33^{\circ} 16^{\prime}$ south, longitude $50^{\circ} 10^{\prime}$ west, the water giving at this time $68 \frac{1}{2}^{\circ}$ to $69 \frac{1}{2}^{\circ} \mathrm{F}$. Beechey in August obtained $68^{\circ} \mathrm{F}$. in $31^{\circ}$ south, $46^{\circ}$ west. The isocryme of $68^{\circ} \mathrm{F}$. thus bends far south, reaching at least the parallel of $30^{\circ}$. It takes a course nearly parallel with the line of $74^{\circ} \mathrm{F}$., as different observations show, and passing just south of St. Helena, reaehes the African eoast, near latitude $7^{\circ}$ south. Fitzroy, on July 10 (mid-winter), had a seatemperature of $682^{\circ}{ }^{\circ}$ near St. Helena; and Vaillant, in the Bonite, in September found the sea-temperature $68 \cdot 7^{\circ}$ to $69 \cdot 26^{\circ} \mathrm{F}$.

Isocrymes of $56^{\circ}$ and $50^{\circ} \mathrm{F}$.-These two isocrymes leave the Ameriean coast rather nearly together. The former eommenees just north of the entranee of the La Plata. Fitzroy, in July 23 to 31, 1832, found the sea-temperature at Montevideo $56^{\circ}$ to $58^{\circ} \mathrm{F}$., and in August, $57^{\circ}$ to $54 \frac{1}{2}{ }^{\circ} \mathrm{F}$. These observations would lead to $56^{\circ} \mathrm{F}$. as nearly the mean of the eoldest montl. The temperature $56^{\circ} \mathrm{F}$. was also observed in $35^{\circ}$ south, $53^{\circ}$ west, and at $36^{\circ}$ south, $56^{\circ} 36^{\prime}$ west. But on July 10 and 13, 1833, at Montevideo, the sea-temperature was $46 \frac{1}{2}{ }^{\circ}$ to $47 \frac{1}{2}$, a degree of cold whieh, although only occasional, throws the line of $56^{\circ} \mathrm{F}$. to the north of this plaee. The temperature near the land is several degrees of Fahrenheit lower than at sea three to eight degrees distant. East of the mouth of the La Plata, near longitude $50^{\circ}$ west, Beeehey, in July, 1828 , found the temperature of the sea $61 \cdot 86^{\circ}$. F. So in April 23 to 29, Vaillant obtained the temperature $59.5^{\circ}$ to $61 \cdot 25^{\circ} \mathrm{F}$. at Montevideo, while in $35^{\circ} 5^{\prime}$ south, $49^{\circ} 23^{\prime}$ west, on A pril 14 , it was $66.2^{\circ} \mathrm{F}$., and farther south, in $37^{\circ} 42^{\prime}$ south, $53^{\circ} 28^{\prime}$ west, April 30 , it was $64^{\circ} 4^{\circ} \mathrm{F}$; ; and in $39^{\circ} 19^{\prime}$ south, $54^{\circ} 32^{\prime}$ west, on May 1 , it was $57^{\circ}{ }^{\circ} \mathrm{F}$.; but a little to the westward, on May 2, in $40^{\circ} 30^{\prime}$ south, $56^{\circ} 54^{\prime}$ west, the temperature was $48^{\circ} \mathrm{F}$., an abrupt transition to the colder shore waters. Beeehey, in $39^{\circ} 31^{\prime}$ south, $45^{\circ} 13^{\prime}$ west, on August 28 (last of winter), found the temperature $57^{\circ} 25^{\circ} \mathrm{F}$., and on the 29 th, in $40^{\circ} 27^{\prime}$ south, $45^{\circ} 46^{\prime}$ west, it was $54 \cdot 20^{\circ}$; while on the next day, in $42^{\circ} 27^{\prime}$ south, and $45^{\circ} 11^{\prime}$ west, the temperature fell to $47.83^{\circ} \mathrm{F}$. These and other observations serve to fix the position of the isoeryme of $56^{\circ} \mathrm{F}$. It approaehes the African coast, in $32^{\circ}$ south, but bends upward, owing to eold waters near the land. On August 20, Vaillant, in $33^{\circ} 43^{\prime}$ south, $15^{\circ} 51^{\prime}$ east, found the temperature $56^{\circ} \mathrm{F}$; ; while on the $22 \mathrm{~d}$, in the same latitude, and $14^{\circ} 51^{\prime}$ east (or one degree farther to the westward), the temperature was $57.74^{\circ} \mathrm{F}$, being nearly two degrees warmer. At Cape Town, in June 
(latitude $34^{\circ}$ ), Fitzroy found $55^{\circ}$ to $61^{\circ} \mathrm{F}$., while on August 16, farther south, in $35^{\circ} 4^{\prime}$ south, and $15^{\circ} 40^{\prime}$ west, one hundred and fifty miles from the Cape, Vaillant found the temperature $59.36^{\circ} \mathrm{F}$. The high temperature of the last is due to the warm waters that come from the Indian Ocean, and which afford $61^{\circ}$ to $64^{\circ} \mathrm{F}$. in August, off the south extremity of Africa, west of the meridian of Cape Town.

The isocryme of $50^{\circ} \mathrm{F}$. leaves the American coast just south of the La Plata; after bending southwardly to the parallel of $41^{\circ}$, it passes east nearly parallel with the line of $56^{\circ} \mathrm{F}$. It does not reach the African coast.

Isocrymes of $44^{\circ}$ and $35^{\circ} \mathrm{F}$.-Fitzroy in August (the last winter month) of 1833 , found the sea-temperature at Rio Negro (latitude $41^{\circ}$ south) $48 \frac{1}{2}^{\circ}$ to $50^{\circ} \mathrm{F}$. But during the voyage from the La Plata to Rio Negro, a few days before, a temperature of $44 \frac{1}{2}^{\circ}$ to $46^{\circ}$ was met with; this was in the same month in which the low temperature mentioned on a preceding page was found at Montevideo. The bend in the coast north of the entrance to the La Plata, is to some extent, a limit between the warmer waters of the north and the colder waters from the south; not an impassable limit, but one which is marked often by a more abrupt transition than occurs elsewhere along this part of the coast. The water was generally three or four degrees colder at Montevideo, than at Maldonado, the latter port being hardly sheltered from the influence of the tropical waters, while Montevideo is wholly so. The exact point where the line of $44^{\circ} \mathrm{F}$. reaches the coast is somewlat uncertain, yet the fact of its being south of Rio Negro is obvious. After leaving the coast, it passes north of $472^{\circ}$ south, in longitude $53^{\circ}$ west, where Beechey, in July, 1828, found the sea-temperature $40.70^{\circ} \mathrm{F}$.

The line of $35^{\circ} \mathrm{F}$. through the middle of the South Atlantic, follows nearly the parallel of $50^{\circ}$; but towards South America it bends southward and passes south of the Falklands and Fuegia. At the Falklands, Captain Ross, in 1842, found the mean temperature of the sea for July, $38.73^{\circ}$, and for August, $38.10^{\circ}$; while in the middle of the Atlantic, on March 24 , latitude $52^{\circ} 31^{\prime}$ soutl, and longitude $8^{\circ} 8^{\prime}$ east, the temperature was down to $34.3^{\circ} \mathrm{F}$., and in $50^{\circ} 18^{\prime}$ south, $7^{\circ} 15^{\prime}$ east, it. was $37^{\circ} \mathrm{F}$.; March 20 , in $54^{\circ} 7^{\prime}$ south, on the meridian of Greenwich, it was $33.4^{\circ} \mathrm{F}$. The month of March would not give the coldest temperature. The temperature of the sea along the south coasts 
of Fucgia sinks nearly to $35^{\circ}$, if not quite, and the line of $35^{\circ}$ therefore runs very near Cape Horn, if not actually touching upon Fuegia.

North Pacific Ocean.-Isocryme of $80^{\circ} \mathrm{F}$.- The waters of the Atlantic in the warmest rcgions, sink below $80^{\circ} \mathrm{F}$. in the colder season, and there is thereforc no proper Supertorrid Region in that ocean. In the Gulf of Mexico, where the heat rises at times to $85^{\circ} \mathrm{F}$., it sinks in other seasons to $74^{\circ}$ and in some parts, even to $72^{\circ} \mathrm{F}$.; and along the Thermal cquator across the ocean, the temperature is in some portions of the year $78^{\circ}$, and in many places $74^{\circ}$.

But in the Pacific, where the temperature of the waters rises in some places to $88^{\circ} \mathrm{F}$, there is a small region in which through all seasons, the heat is never below $80^{\circ}$. It is a narrow area, extending from $165^{\circ}$ east to $148^{\circ}$ west, and from $7 \frac{1}{2}{ }^{\circ}$ north to $11^{\circ}$ south. In going from the Feejees in August, and crossing between the meridians of $170^{\circ}$ west and $180^{\circ}$, the temperature of the waters, according to Captain Wilkes, increased from $79^{\circ}$ to $84^{\circ} \mathrm{F}$., the last temperature being met with in latitude $5^{\circ}$ south, longitude $175^{\circ}$ west, and from this, going northward, there was a slow decrease of temperature. The Ship Relief, of the Expedition, in October, found nearly the same temperature $\left(83 \frac{1}{2}^{\circ}\right)$ in the samc latitude and longitude $177^{\circ}$ west.* But the Peacock, in January and February (summer months), found the sea-temperature $85^{\circ}$ to $88^{\circ} \mathrm{F}$., near Fakaafo, in latitude $10^{\circ}$ south, and longitude $171^{\circ}$ west. In latitude $5^{\circ}$ south and the same longitude, on the 16 th of January, the temperature was $84^{\circ}$; in $3^{\circ}$ south, January 10 th, it was $83^{\circ} \mathrm{F}$.; on March 26th, in $5^{\circ}$ south, and longitude $175^{\circ}$ east, the temperature was $86^{\circ} \mathrm{F}$.; on April 10th, in the same longitude, under the equator, at the Kingsmills, the temperature was $83 \frac{1}{2}^{\circ} \mathrm{F}$; ; on May $2 \mathrm{~d}$, at $5^{\circ}$ north, longitude $174^{\circ}$ east, $83 \frac{1}{2}^{\circ} \mathrm{F}$.; May 5tll, latitude $10^{\circ}$, longitude $169^{\circ}$ east, $82^{\circ} \mathrm{F}$. The fact that the region of greatest heat in the Middle Pacific is south of the equator, as it has been laid down by different authors, is thus evident; the limits of a circumscribed region of hot waters in this part of the Pacific, were first drawn out by Captain Wilkes.

Another Supcrtorrid region may exist in the Indian Ocean, about its northwestern portion; but we have not sufficient information for laying down its limits.

Isocryme of $74^{\circ}$ F.-At San Blas, on the coast of Mexico, Beechey

* See, for these facts, Captain Wilkes's Report on the Meteorology of the Expedition. 
found the mean temperature of the sea for Deember, 1827, $74.63^{\circ}$ F.; for January, $73.69^{\circ} \mathrm{F}$; f for February, $72.40^{\circ} \mathrm{F}$. The line of $74^{\circ}$ F. eommenees therefore a degree or two south of San Blas. In the winter of 1827 on January 16 to 18 , the temperature of $74.3^{\circ}$ to $74.6^{\circ} \mathrm{F}$. was found by Beeehey, in $16^{\circ} 4^{\prime}$ to $16^{\circ} 15^{\prime}$ north, $132^{\circ}$ $40^{\prime}$ to $135^{\circ}$ west; and farther west, in the same latitude, longitude $141^{\circ} 58^{\prime}$ west, the temperature was $74.83^{\circ} \mathrm{F}$. West of the Sandwieh Islands, near the parallel of $20^{\circ}$ nortli, the temperature rises five degrees in passing from the meridian of $165^{\circ}$ west to $150^{\circ}$ east, and the isoeryme of $74^{\circ} \mathrm{F}$., eonsequently rises somewhat to the north, over this part of the oeean. Between the meridians of $130^{\circ}$ and $140^{\circ}$ east, the temperature of the sea is quite uniform, indieating no northward flexure; and west of $130^{\circ}$ east, nearing China, there is a rapid deerease of temperature, bending the line far south. Vaillant, of the Bonite, found the sea off Coehin China, in latitude $12^{\circ} 16^{\prime}$ north, $109^{\circ} 28^{\prime}$ east, to have the temperature $74.12^{\circ} \mathrm{F}$; ; and even at Singapore, almost under the equator, the temperature on February 17 to 21 , was $77.54^{\circ}$ to $79.34^{\circ} \mathrm{F}$. The isoeryme of $74^{\circ} \mathrm{F}$. terminates therefore upon the southeastern eoast of Coehin China.

Isocryme of $68^{\circ}$.-Off the Gulf of California, in $25^{\circ}$ north, $117^{\circ}$ west, Beechey obtained for the temperature of the sea, on Deeember 13, $65^{\circ} \mathrm{F}$.; on Deeember 15 , in $23^{\circ} 28^{\prime}$ north (same latitude with the extremity of the peninsula of California), $115^{\circ}$ west, a temperature of $69.41^{\circ} \mathrm{F}$. The line of $68^{\circ}$ will pass from the extremity of this peninsula, the temperature of the coast below, as it is shut off mostly from the more northern and eolder waters, being mueh warmer. The temperature $69.41^{\circ}$ in the middle of Deember, is probably two and a half degrees above the eold of the eoldest month, judging from the relative temperatures of the latter half of Deeember and the month of February at San Blas. Leaving California, the isoeryme of $68^{\circ}$ will therefore bend a little southerly to $222^{\circ}$, in longitude $115^{\circ}$ west. In $23^{\circ} 56^{\prime}$ north, $128^{\circ} 33^{\prime}$ west, Beechey, on January 11, found the temperature of the sea $67.83^{\circ} \mathrm{F}$. The line of $68^{\circ}$ passes north of the Sandwieh Islands. The mean temperature of the sea at Oahu in February, 1827 , was $69 \cdot 69^{\circ} \mathrm{F}$.

Near China, this isoeryme is bent far south. At Maeao, in winter, Vaillant found the sea-temperature, on January $4,59^{\circ} \mathrm{F}$; on January 5 to $10,52 \cdot 7^{\circ}$ to $50^{\circ} \mathrm{F}$.; January $11,12,49 \cdot 87^{\circ}$ to $48 \cdot 74^{\circ} \mathrm{F}$.; January 13 to $16,50.9^{\circ}$ to $52 \cdot 16^{\circ} \mathrm{F}$.; and at Touranne in Coehin China, on February 6 to 24 , the sea-temperature was $68^{\circ}$ to $68 \frac{1}{2}^{\circ} \mathrm{F}$.; in $16^{\circ} 22^{\prime}$ 
north, $108^{\circ} 11^{\prime}$ cast, on January 24 , it was $67^{\circ}$; in $12^{\circ} 16^{\prime}$ north, $109^{\circ} 28^{\prime}$ east, it was $74 \cdot 12^{\circ} \mathrm{F}$. The very low Macao temperaturc is that of the surface of the Bay itself, due to the cold of the land, and not probably, as the other observations show, of the sea outside.

The line, before passing south, bends northward to the southeast shore of Niphon, which is far warmer than the southeast coast, along Kiusiu. In thc Report of the Morrisons' visit to Jeddo (Chinese Repository for 1837), a coral bottom is spoken of, as having been encountered in the harbour of Jeddo. According to Siebold (Crust. Faun. Japon., p. ix.); the mean winter temperaturc (air) of Jeddo is $57^{\circ} \mathrm{F}$., while that of Nagasaki, although farther south, is $44^{\circ} \mathrm{F}$.

Isocryme of $62^{\circ} \mathrm{F}$.-On January 8, 1827, Beechey found in $29^{\circ} 42^{\prime}$ north, $126^{\circ} 37^{\prime}$ west, the temperature $62.75^{\circ} \mathrm{F}$.; while on the preceding day, $32^{\circ} 42^{\prime}$ north, $125^{\circ} 43^{\prime}$ west, the sea-temperature was $60.5^{\circ} \mathrm{F}$. Again, on December 11 , in $29^{\circ}$ north, $120^{\circ}$ west, the temperature was $62.58^{\circ} \mathrm{F}$.

Isocryme of $56^{\circ} \mathrm{F}$.-At Monterey, on January 1 to 5 , the sea-temperature according to Beechey was $56^{\circ}$; but the mean temperature of the sea for November 1 to 17 , was $54.91^{\circ}$. In the Yellow Sea, the January temperature is $50^{\circ}$ to $56^{\circ} \mathrm{F}$, and the line of $56^{\circ}$ begins south of Chusan.

Isocryme of $50^{\circ}$ F.-At San Francisco, from November 18 to Decernber 5,1826 , Beechey found the mean sea-temperature to be $51 \cdot 14^{\circ}$ $\mathrm{F}$., and off Montcrey, in longitudc $123^{\circ}$ west, the temperature was $50.75^{\circ} \mathrm{F}$., on December 6 . But in December of 1826 , the mean seatemperature at San Francisco was $54 \cdot 78^{\circ} \mathrm{F}$; ; and for November, $60 \cdot 16^{\circ} \mathrm{F}$. The line of $50^{\circ} \mathrm{F}$. (mean of the coldest thirty consecutive days), probably leaves the coast at Cape Mendocino.

Isocrymes of $44^{\circ}$ and $35^{\circ} \mathrm{F}$.-Captain Wilkes found the temperature off the mouth of the Columbia River, through ten degrees of longitude, $48^{\circ}$ to $49^{\circ} \mathrm{F}$, during the last of April, 1841. The isocryme of $44^{\circ}$ would probably reach the coast not far north of this place. The temperature on October 21 , in the same latitude, but farther west, $147^{\circ}$ west, was $52.08^{\circ} \mathrm{F}$. On October 16 , in $50^{\circ}$ north, $169^{\circ}$ west, the tempcrature was $44.91^{\circ} \mathrm{F}$. According to some oceanic temperatures for the North Pacific, obtained from Lieutenant Maury, the sea-temperature off northern Niphon, in $41^{\circ}$ north and $1422^{\circ}$ east, was $44^{\circ} \mathrm{F}$., in March, showing the influcnce of the cold Polar current; and in $42^{\circ}$ north, and $149 \frac{1}{2}^{\circ}$ east, it was $43^{\circ} \mathrm{F}$. The line of $44^{\circ}$ hence bends southward as far as latitude $40^{\circ}$ north, on the Japan coast. 
Again, in March, in $43^{\circ} 50^{\prime}$ north, $151^{\circ}$ east, the sea-tempcrature was $41^{\circ} \mathrm{F}$; ; in $44^{\circ} 50^{\prime}$ north, $152^{\circ} 10^{\prime}$ east, $39^{\circ} \mathrm{F}$; in $46^{\circ} 20^{\prime}$ north, $156^{\circ}$ east, $33^{\circ} \mathrm{F}$; ; in $49^{\circ}$ north, $157^{\circ}$ east, $33^{\circ} \mathrm{F}$; ; and at the same time, west of Kamschatka, in $55^{\circ}$ north, $153^{\circ}$ cast, $38^{\circ} \mathrm{F}$.; in $55^{\circ} 40^{\prime}$ north, $153^{\circ}$ west, $38^{\circ} \mathrm{F}$. The linc of $35^{\circ}$ consequently makes a deep bend, ncarly to $45^{\circ}$ north, along the Kurile Islands.

South PACIFIC.-Tsocrymes of $74^{\circ}, 68^{\circ}$, and $62^{\circ}$ F.-The temperature of the sea at Guayaquil, on August 3d, was found by Vaillant, to be, in the river, from $70 \frac{1}{2}^{\circ}$ to $73 \frac{1}{2}^{\circ} \mathrm{F}$., and at the Puna anchorage, August 5 to $12,74 \cdot 7^{\circ}$ to $75 \cdot 2^{\circ} \mathrm{F}$. But off the coast, August 15, in $2^{\circ} 22^{\prime}$ south, $81^{\circ} 42^{\prime}$ west, the temperature was $69.8^{\circ} \mathrm{F}$; ; and the next day, in $1^{\circ} 25^{\prime}$ south, $84^{\circ} 12^{\prime}$ west, it was $70^{\circ} \mathrm{F}$.; on the $17 \mathrm{th}, 1^{\circ}$ south, $87^{\circ} 42^{\prime}$,west, it was $71.28^{\circ} \mathrm{F}$; ; and on the 14 th, nearer the shore of Guayaquil, in $3^{\circ} 18^{\prime}$ south, $80^{\circ} 28^{\prime}$ west, it was $78^{\circ} \mathrm{F}$. Again, at Payta, one hundred miles south of Guayaquil, in $5^{\circ}$ south, the sea-temperature was found by Vaillant, July 26 to 31 , to be $60.8^{\circ}$. to $61 \frac{1}{2}^{\circ} \mathrm{F}$. The isocryme of $74^{\circ} \mathrm{F}$., consequently, leaves the coast just north of the bay of Guayaquil, while those of $68^{\circ}$ and $62^{\circ} \mathrm{F}$., both commence between Guayaquil and Payta. Payta is situated so far out on the western cape of South America that it receives the cold waters of the south, while Guayaquil is beyond Cape Blanco, and protected by it from a southern current. At the Gallapagos, Fitzroy found the tcmperature as low as $582^{\circ} \mathrm{F}$. on the 29 th of September, and the mean for the day was $62^{\circ}$. The average for September was, howcver, nearer $66^{\circ}$. The Gallapagos appear, therefore, to lie in the Warm Temperate Region, between the isocrymes of $62^{\circ}$ and $68^{\circ} \mathrm{F}$. Fitzroy, in going from Callao to the Gallapagos, early in September, left a sea-temperature of $57^{\circ} \mathrm{F}$. at Callao, passed $62^{\circ} \mathrm{F}$. in $9^{\circ} 58^{\prime}$ north, and $79^{\circ} 42^{\prime}$ west, and on the $15 \mathrm{th}$, found $68 \frac{1}{2}^{\circ} \mathrm{F}$. off Barrington Island, one of the Gallapagos.

In the warm season, the cold waters about the Gallapagos have narrow limits; Beechey found a sea-temperature of $83.58^{\circ}$ on the 30 th . of March, 1827, just south of the equator, in $100^{\circ}$ west. But in October, Fitzroy, going westward and southward from the Gallapagos, found a sea-temperature of $66^{\circ} \mathrm{F}$. at the same place; and in a nearly straight course from this point to $10^{\circ}$ south, $120^{\circ}$ west, found the seatemperatures successively, $68^{\circ}, 70^{\circ}, 70.5^{\circ}, 72.5^{\circ}, 73.5^{\circ}, 74^{\circ} ;$ and beyond this, $75 \frac{1}{2}^{\circ}, 76 \frac{1}{2}^{\circ}, 77 \frac{1}{2}{ }^{\circ} \mathrm{F}$., the last on November 8 , in $14^{\circ} 24^{\prime}$ 
south, $136^{\circ} 51^{\prime}$ west. These observations give a wide sweep to the cold waters of the colder seasons, and throw the isocrymes of $74^{\circ}$ and $68^{\circ} \mathrm{F}$, far west of the Gallapagos. Captain Wilkes, in passing directly west from Callao, found a temperature of $68^{\circ} \mathrm{F}$., in longitude $85^{\circ}$ west; $70^{\circ} \mathrm{F}$., in $95^{\circ}$ west; and $74^{\circ} \mathrm{F}$., in $102^{\circ}$ to $108^{\circ}$ west. These and other observations lead to the positions of the isocrymes of $74^{\circ}$, $68^{\circ}$, and $62^{\circ}$, given on the Chart. The line of $74^{\circ}$ passes close by Tahiti and Tongatabu, and crossing New Caledonia, reaches Australia in latitude $25^{\circ} \mathrm{S}$.

In mid-ocean there is a bend in all the southern isocrymes.*

* The following obscrvations by Mr. W. C. Cunningham (in connexion with those of other navigators), establish the fact of this flexure; they were sent by him to the author, in a letter, dated Talcahuano, Chili.

1. FROM THE HARBOUR OF APIA, ISLAND OT DPOLD, TO TAHITI.

\begin{tabular}{|c|c|c|c|c|c|c|}
\hline DATE. & LATITUDE. & LOYAITODE. & พเXD8. & BEA.† & Asr. $f$ & WEATEER. \\
\hline $\begin{array}{r}\text { May } 11 \\
12 \\
13 \\
14 \\
15 \\
16 \\
17 \\
18 \\
19 \\
20 \\
21 \\
22 \\
23 \\
24 \\
25 \\
26 \\
27 \\
28 \\
29 \\
30 \\
31 \\
\text { June } 1 \\
2 \\
3\end{array}$ & 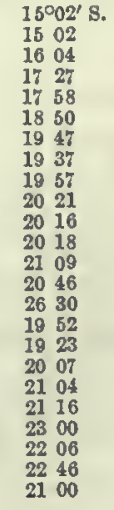 & 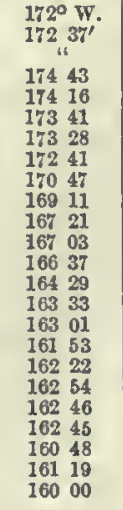 & $\begin{array}{l}\text { N.E. } \\
\text { S.S.E. } \\
\text { E. by S. } \\
\text { S.E. } \\
\text { J.E. } \\
\text { S.E. } \\
\text { S.E. } \\
\text { S. } \\
\text { S. } \\
\text { S. by E. } \\
\text { S. by E. } \\
\text { Var. } \\
\text { S. } \\
\text { S. } \\
\text { S. } \\
\text { S. } \\
\text { S.E. } \\
\text { S.E. } \\
\text { S.S.E. } \\
\text { E.S.E. } \\
\text { N.N.E. } \\
\text { V.r. } \\
\text { S.S.W. } \\
\text { E. }\end{array}$ & 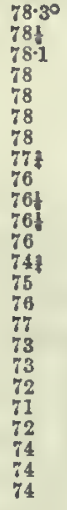 & $\begin{array}{l}77^{\circ} \\
78 \\
78 \\
78 \\
77 \\
76 \\
76 \\
71 \\
75 \\
74 \\
72 \\
74 \\
76 \\
75 \\
744 \\
75 \\
75 \\
76 \\
76 \\
76 \\
76 \\
76 \\
74 \\
75\end{array}$ & $\begin{array}{l}\text { Fine. } \\
\text { Showery. } \\
\text { Dark. heavy rains. } \\
\text { Fine, but clondy. } \\
\text { "" } \\
\text { Clear. } \\
\text { Clear and fine. } \\
\text { Cloudy. } \\
\text { " } \\
\text { " } \\
\text { Clear. } \\
\text { Dark. } \\
\text { Cloudy. } \\
\text { Fine. } \\
\text { Dark. } \\
\text { "6 } \\
\text { Fine. } \\
\text { Cloudy. } \\
\text { "Clear. } \\
\text { Fine. } \\
\text { Clear. } \\
\text { Fine; at Raratonga. I }\end{array}$ \\
\hline $\begin{array}{l}11 \\
12 \\
13 \\
14 \\
15 \\
16\end{array}$ & $\begin{array}{l}2221 \\
2224 \\
2249 \\
2229 \\
2226 \\
22 \quad 37\end{array}$ & 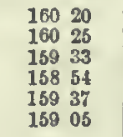 & $\begin{array}{l}\text { E. } \\
\text { E. } \\
\text { Var. } \\
\text { E. by } . \text {. } \\
\text { N.N.E. } \\
\text { Var. }\end{array}$ & $\begin{array}{l}73 \\
73 \\
73 \\
72 \\
71 \\
71\end{array}$ & $\begin{array}{l}7^{2} \\
72 \\
72 \\
72 \\
71 \\
71\end{array}$ & $\begin{array}{l}\text { Fine. } \\
\text { " } \\
" \\
" \\
\text { At Mangaia. }\end{array}$ \\
\hline $\begin{array}{l}17 \\
18 \\
19 \\
20 \\
21 \\
22 \\
23 \\
24 \\
25\end{array}$ & $\begin{array}{rl}\vdots & \cdot \\
21 & 39 \\
21 & 06 \\
20 & 53 \\
20 & 36 \\
20 & 21 \\
19 & 10 \\
. & .\end{array}$ & $\begin{array}{cl}: & : \\
156 & 42 \\
155 & 47 \\
154 & 20 \\
152 & 34 \\
151 & 18 \\
151 & 11 \\
. & \end{array}$ & $\begin{array}{l}\text { Var. } \\
\text { S.S.E. } \\
\text { S.E. } \\
\text { S.S.E. } \\
\text { S.S.H. } \\
\text { S.S.E. } \\
\text { S.E. } \\
\text { S.E. } \\
\text { E. }\end{array}$ & $\begin{array}{l}70 \\
68 \\
68 \\
68 \\
68 \\
68 \\
70 \\
71 \\
\end{array}$ & $\begin{array}{l}71 \\
72 \\
72 \\
73 \\
74 \\
76 \\
76 \\
76 \\
.\end{array}$ & $\begin{array}{l}\text { Fine. } \\
\text { " } \\
\text { Dark. } \\
\text { " } \\
\text { Fine. } \\
\text { " } \\
\text { " } \\
\text { At Tahiti. }\end{array}$ \\
\hline
\end{tabular}

+ Mesn temperature. 
GEOGRAPHICAL DISTRIBUTION OF CRUSTACEA. 1467

Isocrymes of $56^{\circ}$ and $50^{\circ} \mathrm{F}$.-The temperature at Callao, in July, averages $58 \frac{1}{2}^{\circ}$ or $59^{\circ} \mathrm{F}$. At Iquique, near $20^{\circ}$ south, Fitzroy had $58^{\circ}$ to $60^{\circ} \mathrm{F}$., on July 14, 1835 ; and off Copiapo, in the same month, $56 \frac{1}{2} \circ \mathrm{F}$. At Valparaiso, Captain Wilkes found a sea-temperature of $52 \frac{1}{2}{ }^{\circ} \mathrm{F}$., in May; and Fitzroy, in September, occasionally obtained $48^{\circ} \mathrm{F}$., but generally $52^{\circ}$ to $53^{\circ}$. Off Chiloe, Fitzroy found the temperature $48^{\circ}$ to $512^{\circ}$ in July.

2. FROM TAHITI TO VALPARAI8O.

\begin{tabular}{|c|c|c|c|c|c|c|}
\hline DATE. & LATTEDB. & IONOITUDE. & WIXDE. & SEA.* & AIR.* & REYARX. \\
\hline $\begin{array}{r}\text { Aug. } 26 \\
27 \\
28 \\
29 \\
30 \\
31 \\
31 \\
\text { Sept. } 1 \\
2 \\
3 \\
4 \\
6 \\
6 \\
6 \\
7 \\
8 \\
8 \\
10 \\
11 \\
12 \\
13 \\
14 \\
15 \\
16 \\
17 \\
18 \\
19 \\
20 \\
21 \\
22 \\
23 \\
24 \\
25 \\
26 \\
27 \\
28 \\
29 \\
30 \\
0 \text {. } \\
2 \\
2 \\
3 \\
4 \\
6 \\
6 \\
7 \\
8 \\
0 \\
10 \\
11 \\
12 \\
13 \\
14 \\
15 \\
16 \\
\end{array}$ & $\begin{array}{ll}18077 \\
20 & 10 \\
22 & 02 \\
22 & 18 \\
22 & 30 \\
23 & 15 \\
24 & 24 \\
25 & 14 \\
26 & 13 \\
27 & 18 \\
28 & 46 \\
28 & 40 \\
29 & 21 \\
30 & 19 \\
31 & 30 \\
32 & 30 \\
33 & 45 \\
34 & 42 \\
35 & 43 \\
36 & 50 \\
38 & 19 \\
39 & 23 \\
40 & 18 \\
40 & 01 \\
39 & 05 \\
38 & 24 \\
38 & 09 \\
37 & 42 \\
37 & 23 \\
36 & 52 \\
37 & 05 \\
37 & 05 \\
37 & 11 \\
37 & 03 \\
36 & 47 \\
36 & 48 \\
36 & 29 \\
36 & 22 \\
36 & 42 \\
37 & 12 \\
36 & 58 \\
37 & 11 \\
36 & 18 \\
35 & 28 \\
34 & 14 \\
34 & 06 \\
34 & 03 \\
34 & 48 \\
33 & 39 \\
33 & 33 \\
33 & 10\end{array}$ & 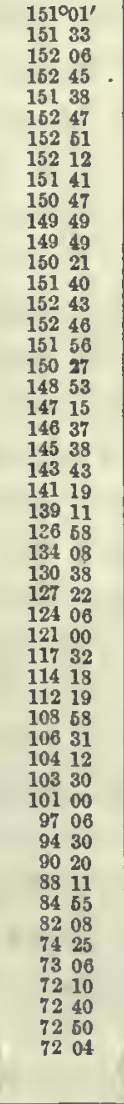 & $\begin{array}{c}\text { S.E. } \\
\text { S.E. } \\
\text { S.E. } \\
\text { S.E. } \\
\text { Var. } \\
\text { S.E. } \\
\text { S.S.E. } \\
\text { N.N.E. } \\
\text { S.W. } \\
\text { S.W. } \\
\text { S.W. } \\
\text { S.W. } \\
\text { W. } \\
\text { S.E. } \\
\text { S.E. } \\
\text { S.E. } \\
\text { Var. } \\
\text { Var. } \\
\text { N.E. } \\
\text { N.E. } \\
\text { Var. } \\
\text { N.N.E. } \\
\text { N.E. } \\
\text { N.E. } \\
\text { N.N.E. } \\
\text { N. by.W. } \\
\text { N.N.W. } \\
\text { N.N.E. } \\
\text { N.N.W. } \\
\text { N.N.W. } \\
\text { N.W. } \\
\text { W. } \\
\text { N.W. } \\
\text { Var. } \\
\text { N.W. } \\
\text { W. } \\
\text { Var. } \\
\text { Var. } \\
\text { N.N.W. } \\
\text { N.W. } \\
\text { W.N.W. } \\
\text { W.N.W. } \\
\text { W.N.W. } \\
\text { N.W. } \\
\text { N.W. } \\
\text { Var. } \\
\text { S.W. } \\
\text { N.N.E. } \\
\text { N. } \\
\text { N.W. } \\
\text { S. }\end{array}$ & $\begin{array}{l}73 \circ \\
72 \\
72 \\
75 \\
76 \\
68 \\
68 \\
69 \\
69 \\
65 \\
63 \\
62 \\
61 \\
60 \\
68 \\
58 \\
58 \\
66 \\
66 \\
56 \\
658 \\
53 \\
50 \\
52 \\
55 \\
56 \\
56 \\
56 \\
55 \\
56 \\
58 \\
56 \\
56 \\
58 \\
57 \\
57 \\
58 \\
55 \\
58 \\
58 \\
58 \\
56 \\
57 \\
56 \\
54 \\
57 \\
57 \\
57 \\
56 \\
56 \\
56 \\
56\end{array}$ & $\begin{array}{l}70^{\circ} \\
75 \\
75 \\
73 \\
72 \\
72 \\
72 \\
72 \\
70 \\
66 \\
68 \\
66 \\
65 \\
65 \\
60 \\
60 \\
571 \\
68 \\
56 \\
66 \\
65 \\
52 \\
61 \\
52 \\
54 \\
55 \\
64 \\
55 \\
54 \\
54 \\
57 \\
55 \\
54 \\
57 \\
55 \\
55 \\
57 \\
56 \\
56 \\
57 \\
56 \\
64 \\
55 \\
56 \\
56 \\
57 \\
56 \\
57 \\
57 \\
57 \\
56 \\
54\end{array}$ & 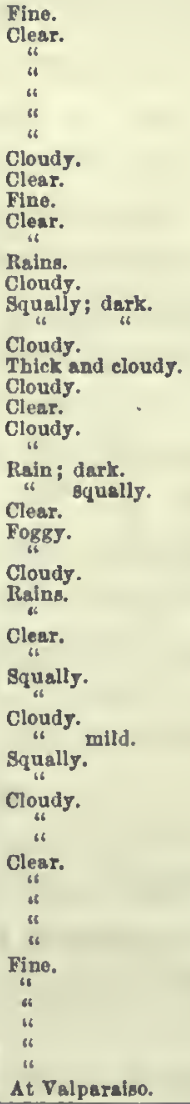 \\
\hline
\end{tabular}

* Mean temperature. 
INDIAN Ocean.-Isocrymes of $74^{\circ}$ and $68^{\circ} \mathrm{F}$.-Off the south extremity of Madagascar, in $27^{\circ} 33^{\prime}$ south, $47^{\circ} 17^{\prime}$ east, on August 4th, Vaillant found the temperature $69.26^{\circ} \mathrm{F}$; ; and in $29^{\circ} 34^{\prime}$ south, $46^{\circ} 46^{\prime}$ east, the temperature of $67.84^{\circ} \mathrm{F}$; off South Africa, August 12 , in $34^{\circ} 42^{\prime}$ south, $27^{\circ} 25^{\prime}$ east, the temperature $63.5^{\circ} \mathrm{F}$; on August 14 , in $35^{\circ} 41^{\prime}$ south, $22^{\circ} 34^{\prime}$ east, a temperature of $63.3^{\circ} \mathrm{F}$; while off Cape Town, two hundred miles to the west, the temperature was $50^{\circ}$ to $54^{\circ} \cdot \mathrm{F}$.

In the above review, we have mentioned only a few of the observations which have been used in laying down the lines, having selected those which bear directly on some positions of special interest, as regards geographical distribution.

The Chart also contains the heat-equator, - a line drawn through the positions of greatest heat over the oceans. It is a shifting line, varying with the seasons, and hence, there is some difficulty in fixing upon a course for it. We have followed mainly the Chart of Berghaus. But we have found it neeessary to give it a much more northern latitude in the western Pacific, and also a flexure in the western Atlantic, both due to the currents from the south that flow up the southern continents.

Vaillant, passing from Guayaquil to the Sandwich Islands, found the temperature, after passing the equator, slowly increase from $76^{\circ}$ F., August 19, in $2^{\circ} 39^{\prime}$ north, $91^{\circ} 58^{\prime}$ west (of Greenwich), to $81.9^{\circ}$ F., in August $31,11^{\circ} 15^{\prime}$ north, $107^{\circ} 3^{\prime}$ west, after which it was not above $80^{\circ} \mathrm{F}$. The same place in the ocenn which gave Vaillant $76^{\circ}$ F., in August, afforded Fitzroy ( $4^{\circ}$ north, $96^{\circ}$ west), on March 26 (when the sun had long been far north), $82 \frac{1}{2}^{\circ} \mathrm{F}$. This shows the variations of temperature that take place with the change of season.

REMARKS ON THE SEVERAL REGIONS.

The form and varying breadth of the different regions, and the relations between the sea-temperatures of coasts in different latitudes, which they exhibit, are points demanding special remark.

1. Atlantic Torrid Region, between $74^{\circ}$ F. north, and $74^{\circ}$ F. south.The form of this region is triangular, with the vertex of the triangle 
to the east. Its least width is four degrees of latitude; its greatest width between the extreme latitudes, is forty-six and a half degrees, On the African coast it includes only a part of the coast of Guinea, and no portion is south of the equator. On the west, it embraces all the West India Islands and reefs (excepting the Little Bahama), and the South American coast, from Yucatan to Bahia,-a fact that accounts for the wide distribution of marine species on the American side of the ocean.

2. Atlantic Subtorrid Regions, between $74^{\circ}$ and $68^{\circ}$ F.-The North Subtorrid Region of the Atlantic is about six degrees in its. average width, which is equivalent to a degree of Fahrenheit to each degree in surface. It encloses within the same temperature limits, a part of the east coast of Florida, between $24^{\circ}$ and $27 \frac{1}{2}^{\circ}$ north, and a part of the African coast, between the parallels of $9^{\circ}$ and $14 \frac{1}{2}^{\circ}$ north, the two related coasts differing ten degrees in latitude. The Bermudas, in latitude $33^{\circ}$, and the Cape Verdes, in $15^{\frac{1}{2}}$, fall within this region.

The South Subtorrid Region has the same average width as the northern.

Taking the whole Atlantic Torrid or Coral-reef zone together, its width on the east is about twenty-one degrees, while on the west, it extends betwcen the parallels of $30^{\circ}$ south and $34^{\circ}$ north, a breadth of sixty-four degrees. As many species will thrive under the temperature of any part of the Torrid zone, the geographical range of such species in the Atlantic may be very large, even from Florida and the Bermudas on the north, to Rio Janeiro on the south, a range of which there are many actual examples.

Atlantic Warm Temperate Regions, between $68^{\circ}$ and $62^{\circ} \mathrm{F}$.-The northern of these regions has a breadth of fourteen and a half degrees along the west of Africa, and about seven degrees along the United States, soutlı of Cape Hatteras, off the Carolinas, Georgia, and northern Florida. These shores and the Canaries are therefore in one and the same temperature zone.

The southern of these regions averages five degrees in width. The eastern limit on the African coast is sixteen to eighteen degrees to the north of the western on the South American coast.

Atlantic Temperate Regions, between $62^{\circ}$ and $56^{\circ}$ F.-The north Temperate Region is but a narrow strip of water on the west, terminating at Cape Hatteras, on the coast of the United States. To the 
east it widens, and embraces the Azores and the African coast along Morocco, together with the Straits of Gibraltar, and a large part of the Mediterranean. Madeira lies upon its southern linit. It is, therefore, natural, that the same species should occur at the Azores, Madeira, and on the African coast, and be excluded wholly from the Atlantic coast of Europe. This, according to Prof. Forbes, is the fact with the Littorina striata, besides other species. The coasts of Portugal and the Azores are in different regions.

The South Temperate Rcgion extends to Maldonado at the mouth of the La Plata, from near the parallel of $30^{\circ}$; along the African coast it reaches over more than twice the number of degrces of latitude, to within five degrces of Cape Town.

Atlantic Subtemperate Regions, between $56^{\circ}$ and $50^{\circ} \mathrm{F}$.-The northern of these regions, like the preceding, can scarcely be distinguished on the coast of the United States, as the lines $50^{\circ}$ and $56^{\circ} \mathrm{F}$. fall nearly together at Cape Hatteras. On the eastern side of the Atlantic, it occupies the coast of Portugal to latitude $42^{\circ}$ north, having a width of five degrees. It thus corresponds to the so-called Lusitanian Region.

The southern includes the mouth of the La Plata on one side, and on the other the coast near Cape Town, beyond which it extends to the Cape of Good Hope.

Atlantic Cold Temperate Regions, between $50^{\circ}$ and $44^{\circ} \mathrm{F}$.-The coast from Cape Cod to Cape Hatteras belongs to the Northern Cold Temperate Region. Passing easterly, this region is but a narrow line of water for thirty degrees of longitude, after which it expands, and finally terminates between Western Ireland and latitude $42^{\circ}$ on the Spanish coast. The British Channel, the Bay of Biscay, and Vigo Bay, Spain, are within the limits of this region.

The southern embraces the coast of South America along by Rio Negro for about five degrees, and passes wholly to the sonth of Africa.

Atlantic Subfrigid Regions, between $44^{\circ}$ and $35^{\circ} \mathrm{F}$.-The const of Massachusetts, north of Cape Cod, of Maine and Newfoundland, and all Northern Britain, the Orkneys, Shetlands, and Faroe Islands, pertain to the Northern Subfrigid Region; while the southern, includes the Falklands, Southern Patagonia, and Fuegia.

Atlantic Frigid Regions, beyond $35^{\circ}$ F.-Greenland, Iceland, and Norway are within the northern of these regions, and the South Shetlands, Sandwich Land, and South Georgia, within the southern. 
Pucific Regions.-A comparison of the regions of the Atlantic and Pacific, and especially of the limits of those commencing at the South American coasts, brings out some singular facts.

The Torrid region of the Pacific, near the Anierican coast, embraces only seventeen and a half or eighteen degrees of latitude, all but three of which are north of the equator; while that of the Atlantic covers a long range of coast, and reaches to $15^{\circ}$ south. The south Subtorrid Region has a breadth of about three degrees on the Peruvian coast, reaching to $4^{\circ}$ south, while that of the Atlantic extends to Rio Janeiro, in $24^{\circ}$ south. The Warm Temperate Region has a breadth of less than a degree, reaching to Cape Blanco, in $4 \frac{1}{2}^{\circ}$ south, while that of the Atlantic extends to Rio Grande, in $33^{\circ}$ south. The next or Temperate Region has a longer range on the South American coast, extending to Copiapo, in $27 \frac{1}{2}^{\circ}$ south, and the Atlantic region corresponding goes to Maldonado in $35^{\circ}$ south. The Cold Temperate Regions of the two oceans cover nearly the same latitudes.

On the North American coast at Cape Hatteras, the three isocrymes $62^{\circ}, 56^{\circ}$, and $50^{\circ} \mathrm{F}$., leave the coast together; and in the Pacific on the South American coast there is a similar node in the system of isocrymes, the three $74^{\circ}, 68^{\circ}$, and $62^{\circ}$, proceeding nearly together from the vicinity of Cape Blanco.

Viewing these regions through the two oceans, instead of along the coasts, other peculiarities no less remarkable are brought out. The average breadth of the South Torrid Region in the Pacific, is more than twice as great as that of the same in the Atlantic; and the most southern limit of the latter is five degrees short of the limit of the former in mid-ocean. So also, the Subtorrid Region at its greatest elongation southward in the Atlantic, hardly extends beyond the average course of the line of $68^{\circ} \mathrm{F}$. in the Pacific, and the average breadth of the former is but two-thirds that of the latter. The same is true to an almost equal extent of the Warm Temperate and Temperate Regions.

The breadth of the Torrid Region of the Pacific to the eastward, where narrowest, is about six degrees; and to the westward, between its extreme limits, forty-nine degrees. The Torrid zone or Coral-reef Seas, in the same ocean, has a breadth near America, of about eighteen degrees, and near Australia and Asia, of sixty-six degrees.

New Zealand lies within the Subtemperate and Cold Temperate Regions, excepting its southern portion, which appcars to pertain like 
Fuegia to the Subfrigid. Van Diemens Land, exclusive of its northern shores, is within the Cold Temperate.

Indian Occan Regions.-The Torrid Region covers the larger part of the Indian Ocean, including all north of the equator, and embraces the larger part of Madagascar. The Subtorrid extends just beyond Port Natal on the African coast (four degrees of latitude north of Cape Town), where there are coral-reefs. The Warm Temperate and Temperate regions each claim a part of the South African coast, and the latter terminates at the Cape of Good Hope.

It hence follows that Port Natal, in latitude $30^{\circ}$ south, the Hawaiian Islands, and Bermudas lie within regions of the same name. While Cape Town, in latitude $34^{\circ}$ south, is in a like region with northern New Zealand, Valparaiso, the Atlantic shores of Portugal, and the sea between Cape Hatteras and Cape Cod.

Influence of Summer Heat.-The small annual range of temperature (twelve to fourteen degrees in most regions) has been remarked upon, and we have further observed, that the extreme heat has far less influence on the distribution of species than the extreme cold. "There are however some cases in the colder seas, in which the range has but half the extent here mentioned, and in such, the species are likely to differ from those characterizing the same region under other circumstances, approximating to those of the region next exterior. These cases are certain islands, or the extremities of continents, which are exposed to cold ocean winds and currents. The south shores of Fuegia and New Zealand appear to be examples of this kind.

We add a table, enumerating the more important lands or coasts embraced in each of the regions, bringing together those which are of like temperature, and which consequently may be most closely related in species. It is partly in recapitulation of the preceding pages.

\section{TORRID ZONE.}

\section{TORRID REGION.}

A. Atrantic. - 1. West India Islands.

2. Coast of South America, from the northeastern cape of Yucatan, to a degree south of Bahia.

3. Coast of Africa, from $9^{\circ}$ north to $5^{\circ}$ north. 
4. Red Sea, to latitude $20^{\circ}$ (?) north.

5. East coast of Africa, to latitude $261^{\circ}(?)$ south.

B. Indian Ocean.-6. Coast of Persia, India, Malacea, Siam, and Cochin China, to $121^{\circ}$ north, on the eastcrn coast of the last-inentioned country.

7. The islands of the Indian Ocean, north of $16^{\circ}$ south, the northern two-thirds of Madagascar.

8. The East India Islands; also, the northern coast of Australia, from $22^{\circ}$ south on the west side, to $25^{\circ}$ south on the east side.

C. Pacific.-9. The Pacific Islands, betwcen $20^{\circ}$ north and $20^{\circ}$ south, together with the Ladrones, New Caledonia, excepting the southern extremity, also the Tonga Islands, as far as Tongatabu, the Hervey Islands, the Paumotu Islands, as far as the Gambier Islands, and excluding Hawaii on the north.

10. The South American coast, from $17 \frac{1}{2}^{\circ}$ north to $1^{\circ}$ south.

\section{SUBTORRID REGION.}

A. North Athantic.-1. The northern and western coast of Yucatan, and the coast of Mexico and Tcxas, within the Gulf of Mexico.

2. Key West, and the east coast of Florida to $27^{\circ}$ north.

3. The Bermudas.

4. The coast of Africa, from $9^{\circ}$ north to $14 z^{\circ}$ north.

B. Souti Atlantic.-5. The coast of South America, from below Bahia to a degree or two below Rio Janeiro.

6. Ascension Island and St. Helena.

7. West coast of Africa, from $5^{\circ}$ north to $7^{\circ}$ south.

C. Indian OCEan.- -8 . East coast of Africa, from $26 \frac{1}{2}^{\circ}$ south to $31^{\circ}$ south, including Port Natal ; also, northern half of the Red Sea and the Persian Gulf.

9. South extremity of Madagascar, Isle of France, and Mauritius.

10. Western coast of Australia, between $22^{\circ}$ south and $262^{\circ}$ (?) south.

D. Norti Pacific Ocran.-11. Coast of Cochin China, between $121^{\circ}$ north and $15^{\circ}$ north.

12. Formosa, Loochoo (Liukiu), and neighbouring islands, southern shore of Japan, Hawaiian Islands.

13. West coast of North America, from the southcrn extremity of the peninsula of California to $17 \frac{1}{2}^{\circ}$ north.

E. Sovtr Pacific.-14. A small part of the coast of Eastern Australia, between 25 south and $261^{\circ}$ south.

15. The southern extremity of New Caledonia, Pylstaart's Island, Mangaia, Rimetara, Rarotonga, Rurutu, Pitcairn's, Easter Island, and possibly the Gambier Islands.

16. The west coast of South America, ncar Guayaquil, from $1^{\circ}$ to $4^{\circ}$ south.

\section{TEMPERATE ZONE.}

1. WARM TEMPERATE REGION.

A. Norti Atrantic.-1. Coast of Gulf of Mexico, along Louisiana, Mississippi, 
Alabama, and the westcrn side of Florida; also, the eoast of the United States, from $27^{\circ}$ north on the east side of Florida to Capc Hatteras.

2. The Canuries, and the coast of Africa, from $141^{\circ}$ north to $281^{\circ}$ north.

B. Soutr Arlantic.-3. East coast of South America, from a degree south of Rio Janeiro to $30^{\circ}$ south; also, the west coast of Africa, betwecn $7^{\circ}$ south and $14^{\circ}$ south.

C. Indian OCEaN.-4. South A frica, between $31^{\circ}$ south in longitude $30^{\circ}$, and $33^{\circ}$ south in longitude $23^{\circ}$ east.

5. Western eoast of Australia, between $262_{2}^{\circ}$ south, and the southwestern cape, in latitude $34^{\circ}$ south, -including the vicinity of Swan River.

D. Nortir Pacifio Ocean.-6. The Tonquin Gulf, Hainan Island, and the adjoining coast of China.

7. The western coast of the peninsula of California, as far as $287^{\circ}$ north.

\section{TEMPERATE REGION.}

A. Norti Atlantic.-1. Not distinguishable at Cape Hattcras.

2. Azores and Madeira, and the northwest eoast of Africa, between the Straits of Gibraltar and $29^{\circ}$ north.

3. The Mediterranean Sea, excepting probably the eastern eoast and the southern coast east of Tunis, and including Algiers, Nice, Naples, and Sieily. The northern coast borders on the Subtemperate Region, or just passes into it. .

B. Souti Atrantic.-4. The eastern coast of South America, from $30^{\circ}$ south to the eastern cape of the La Plata, and not including Montevideo.

5. The westcrn coast of Africa, between $14^{\circ}$ south and $28^{\circ}$ south.

C. Indian Odean.-6. Southern eoast of Africa, between the Cape of Good Hope and the meridian of $23^{\circ}$ east.

7. The southern shore of Australia.

8. The western part of Kiusiu, including the bay of Nagasaki. (Possibly Subtemperate.)

D. North Paciric Ocean.-9. Coast of California, betwcen $282^{\circ}$ north and $341^{\circ}$ north, at Cape Conception, south of Montercy.

E. South Pacific.-10. East coast of Australia, between latitudes $262^{\circ}$ south and $31^{\circ}$ south(?).

11. West coast of South Ameriea, from Cape Blaneo, north of Payta, in $41^{\circ}$ south, to Copiapo, in $27 \frac{1}{2}^{\circ}$ south.

\section{SUBTEMPERATE REGION.}

A. Nortu Atrantic. - 1. Not distinguishable at Cape Hatteras.

2. Coast of Portugal, to $42^{\circ}$ north.

3. Blaek Sea, excepting northern portion?

B. Soutu Atrantic.-4. Mouth of the La Plata.

j. West coast of Africa, from $28^{\circ}$ south to Cape of Good Hope, including Table Bay.

C. North Pacific Ocean.-6. Southern part of eastern coast of Niphon, and the Yellow Sca, from south of Chusan.

7. Californian coast, from $34^{\circ}$ north to Capc Mendocino,--including the Bays of Monterey and San Franeiseo. 
D. Souti Pacific.-8. Southeast angle of Australia, from $30^{\circ}$ south, ineluding Port Jaekson.

9. Northern island of New Zealand, nearly or quite to Cook's Straits.

10. West coast of South America, from $27 \frac{1}{2}^{\circ}$ south to $38^{\circ}$, including the harbours of Coquimbo, Valparaiso, and Valdivia.

\section{COLD TEMPERATE REGION.}

A. North Atlantio.-1. Coast of the United States, from Cape Hatteras to Cape Cod.

2. Southern Britain and Ireland, British Channcl, Bay of Biscay, and northern coast of Spain to $42^{\circ}$ north, including Vigo Bay(?).

B. South Atrantic.-3. East coast of South Ameriea, from the southern eape of the La Plata to $43^{\circ}$ south, including the Bay of Rio Negro.

4. Island of Tristan d'Aeunha.

C. Indian Oogan.-5. St. Paul's and Amsterdam Island.

D. PAcirio. - 6. Van Diemens Land, Middle Island of New Zealand, exeepting southern extremity, Chatham Island.

7. Middlc part of Eastern Niphon to $40^{\circ}$ north.

8. West coast of Ameriea, from Cape Mendoeino to Columbia River, or possibly to the Straits of De Fuea.

9. West eoast of South America, from $38^{\circ}$ south to $49^{\circ}$ or $50^{\circ}$ south, ineluding Chiloe.

\section{SUBFRIGID REGION.}

A. North Atrantic.-1. Massachusetts Bay, coast of Maine, Bay of St. Lawrence, and Southern Newfoundland.

2. Northern Britain, Orkneys, Shetlands.

3. Crimea and north coast of Black Sea?

B. Sotth Atrantic.-4. East coast of South America, below $43^{\circ}$ south, including Fuegia and the Falklands.

C. Indian Ockan.-5. Prinee Edward's Island, Crozet, Kerguelcn's Land.

D. PACIFIC.-6. North part of Niphon, Yeso, the larger part of the Japan and Okhotsk scas; also the northwest coast of Amcrica, from $55^{\circ}$ or $56^{\circ}$ north, nearly or quite to the Columbia River.

7. South extremity of New Zealand, with the Aucklands, and other islands in the vicinity.

\section{FRIGID ZONE.}

1. Eastern eoast of North America, from the cast cape of Newfonndland to the northward, with Greenland, Iceland, the coast of Norway, Cattegat.

2. South Shetlands, South Georgia, Sandwich Land, and other Antarctic Lands. 'The line runs quite elose to Cape Horn.

3. The Aleutian Islands, and castern and southern Kamschatka, and part of the Kuriles. 
The areas of the Torrid, Temperate, and Frigid zones of temperature, either side of the equator, considering $27^{\circ}$ as the normal limit between the first two of these zones, and $60^{\circ}$ the limit between the Frigid and Temperate, are as follows :-

$\begin{array}{llll}\text { Torrid zone, } & \quad & 8,427,000 & \text { square miles (geographieal) } \\ \text { Temperate zone, } & 7,641,000 \text { " } & \text { " } \\ \text { Frigid zone, } & & 2,486,300 ~ " ~\end{array}$

It is hence seen that the Temperate zone, although six degrees wider than the Torrid, has not as large a surface. The species of marine life, if distributed equally over the two, would, therefore, be more numerous in the Torrid zone than in the Temperate, unless the extent of ocean and coast line were far greater in the Temperate than in the Torrid zone, which is not the case. The ocean in the southern Temperate is much more extensive than that of the southern Torrid; but the coast line is far less extensive in the former, as it does not abound in islands, like the Torrid zone.*

The range of temperature is far greater in the Temperate zone than in the Torrid, it being $20^{\circ} \mathrm{F}$. in the latter, and $33^{\circ} \mathrm{F}$. in the former.

In the.Torrid zone, the Subtorrid Region has nearly one-third the

* The following table gives very closely the surface of the zones in square geographical miles, for every $2 \frac{1}{2}$ degrees of latitude to the parallel of $60^{\circ}$ : it is taken from a larger table by Berghaus, in his Länder- und Völker-kunde, i. 47. The first is the zone from the equator to the parallel of $2 \frac{1}{2}^{\circ}$, the seeond, from $2 \frac{1}{2}$ degrees to 5 degrees, and 80 on.

\begin{tabular}{|c|c|c|c|c|}
\hline $2 \frac{1}{2}^{\circ}$ & & & & 809,82 \\
\hline $5^{\circ}$ & & & . & 808,20 \\
\hline $7 \frac{1}{2}^{\circ}$ & & • & & 805,1 \\
\hline $10^{\circ}$ & & & . & 800 \\
\hline $12 \frac{1}{3}^{\circ}$ & & . & & 794,3 \\
\hline $15^{\circ}$ & • & & · & 786,7 \\
\hline $17 \frac{1}{2}^{\circ}$ & & . & & 777 \\
\hline $20^{\circ}$ & • & & . & 766 , \\
\hline $22 \frac{1}{2}^{\circ}$ & & • & & 754, \\
\hline $25^{\circ}$ & & & . & 740, \\
\hline $27 \frac{1}{2}^{\circ}$ & & • & & 70 \\
\hline $0^{\circ}$ & & & & \\
\hline
\end{tabular}

\begin{tabular}{|c|c|c|c|c|}
\hline $32 \frac{1}{2}^{\circ}$ & & & & 692,42 \\
\hline $35^{\circ}$ & . & - & & 673,440 \\
\hline $7 \frac{1}{2}^{\circ}$ & - & & . & 653,172 \\
\hline & . & . & & 631,656 \\
\hline $21^{\circ}$ & • & & . & 608,9 \\
\hline & . & . & 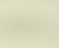 & $585, \mathrm{C}$ \\
\hline$\frac{1}{2}^{\circ}$ & - & & . & 560 \\
\hline & . & . & & 534 , \\
\hline 10 & • & & - & 5 \\
\hline & . & . & & 478, \\
\hline & - & & 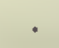 & 1 \\
\hline & & • & & 420 , \\
\hline
\end{tabular}

The zone from $60^{\circ}$ to $70^{\circ}$ has the area, . 
surface of the Torrid Region, and not one-fourth as much coast line, facts which should bc regarded in comparing the number of species of the two.

Before leaving this subject of the Map, we add a few brief remarks, in a popular way, on the origin of the peculiar forms and positions prescnted by the isothcrmal lines of the ocean. The grcat currents of the globe are admitted to be the causes that produce the flcxures and modify the courses of these lincs. Thesc currents arc usually of great depth, and conscquently the deflecting land will be the dceply sented slopes off a coast, beyond ordinary soundings.

The eastern coasts of the contincnts eitlier side of the equator, feel the influence of a warm equatorial current, which flows wcstward over each ocean, and is divcrted north and south by the coasts against which it impinges, and morc or less according to the direction of the coast.

The western coasts of the continents, on the contrary, receive a strong polar current. In the southcrn oceans, it flows from the westward, or southward and westward, in latitudes $45^{\circ}$ to $65^{\circ}$ south, and is brought to the surface by the submarine lands or the submarine slopes of islands or contincnts; reaching the continents of Africa and South America, it follows along the western coast towards the equator. The same current, bcing divided by the southern cape of America, flows also, with less volume up the eastcrn coast, either inside of the warmer tropical current, or else on both sides of it. In the Northern Seas, the system of polar currents is mainly the same, though less regular; their influence is felt on both castern and western coasts, but more strongly on the eastern. In the Atlantic, the latter reduces the temperaturc of the waters three or four degrees along the north coast of South America, as far nearly as Capc St. Roque.

The cold currents are most apparent along the coasts of continents and about islands, because they are here brought to the surface, the submarine slopes lifting them upward, as they flow on. The limits of thcir influence towards the equator depends often on the bend of the coast; for a prominent cape or a bend in the outline will change the exposure of a coast from that favourable to the polar current to that favourable to the tropical, or the reverse. Thus it is at Cape Hatteras, on the coast of the United States; Cape Verde, on Western Africa; Cape Blanco, on western South America, etc. 
Thesc are important principles modifying the courses of the oceanic isothermal lines; we may now proceed to the application of them.

In the Atlantic, the warm tropical current flowing westward, is trended somewhat northward by the northern coast of South Amcrica, and still more so by the West India Islands, and thus it gradually curves around to parallelism with the coast of the United States. But south of Newfoundland, either wholly from the influence of the colder current which it meets with, or in part from meeting with submarine slopes that serve to deflect it, it passes eastward, and afterwards, where it is again free to expand, it spreads both eastward and northeastward. The flexures in the isocrymes of $74^{\circ}$ and $68^{\circ} \mathrm{F}$., near the United States coast, thus have their origin. For the same reason, the line of $56^{\circ} \mathrm{F}$. is nearly straight, till it reaches beyond the influence of the Newfoundland Banks, and then makes its Gulf Stream flexure. The line of $44^{\circ} \mathrm{F}$. for the same reason,-the spreading of the GulfStream waters-diverges far from the equator in its easterly course, and even rises in a long loop between Great Britain and Iceland.

The cold currents, flowing down the eastern coast of America, bend the isocrymes far south close along the coast, and make a remarkable southern.flexure in the isocrymes of $68^{\circ}$ and $56^{\circ} \mathrm{F}$. outside of the Gulf Stream flexure. So on the western coast of Britain, the isocryme of $44^{\circ} \mathrm{F}$. has a deep southern flexure, for a like cause.

The waters of the tropical current gradually cool down in their progress, through the influence of the colder waters which they encounter; and along the isocryme of $62^{\circ}$, they have in the colder seasons a common temperature with that of the ocean, so that the course of the Gulf Stream is but faintly marked in it. And also in the western half of the region covered by the isocryme of $56^{\circ}$, the colder and warmer waters have reached this as a mean temperature. Owing to the influence of the polar current on the northern coast of South America, the equator of heat lies at a distance from the land.

Up the western coast of Africa flows the cold current from the south and west, bending upward all the isocrymal lines; and passing north of the equator, it produces a large southern bend, off the coast of Africa, in the northern isocryme of $74^{\circ}$ outside of the warm current flexure from the coast of Guinea, and also a large northern flexure in the heat-equator.*

\footnotetext{
* Along the ocean, near Africa, south and southeast of thc Cape Verdes, Captain Wilkes found a current setting to the northward for much of the time until passing the equator.
} 
The Atlantic tropical current also flows in part down the castcrn coast of South America, giving a deep flexure to each of the isocrymes, besides making these lines to diverge from the equator, through all their length. Again, the polar current passes nortliward nearer the coast-line, bending far back the western extremity of each of the isocrymes.

In the Pacific, the tropical currents show their cffects ncar the coast of New Holland and China, in a gradual divergence of the lines from the equator. The ranges of islands forming the Tarawan, Radack, and Ralick Groups, appear to divert the current northward in that part of the North Pacific, and consequently the isocrymal lines bend northward near longitudes $170^{\circ}$ west and $180^{\circ}$; and near Niphon, that of $68^{\circ}$ shows a still greater northern flcxure.

The influence of the polar currents in this ocean is remarkably great. The southern flows from the west and south, bending upward the line of $56^{\circ} \mathrm{F}$. along the South American coast, producing at Valparaiso at times a sca-temperature of $48^{\circ} \mathrm{F}$. Still farther north, it throws the line of $68^{\circ} \mathrm{F}$. even bcyond the equator and the Gallapagos; and that of $74^{\circ} \mathrm{F}$., nearly one thousand five hundred miles from the coast, and four hundred north of the equator. The line of $62^{\circ} \mathrm{F}$. reaches even beyond Payta, five degrees south of the equator, the sea-temperature at this place being sometimes below $61^{\circ}$.

The north polar current produces the same result along the castern coast of Asia, as on the eastern of America. The isocryme of $74^{\circ} \mathrm{F}$. is bent southward from the parallel of $23^{\circ}$ to $12^{\circ} 30^{\prime}$ north; and that of $68^{\circ} \mathrm{F}$. from $34^{\circ}$ to $15^{\circ}$ north, and the latter deflection is cven longer than the corresponding one in the Atlantic. The trend of the coast opens it to the continued action of this current until the bend in the outline of Cochin China, below which the cold waters have less influence, although still showing some effect upon the heat-equator. The isocryme of $44^{\circ}$ is bent southward to Niphon, by the same cold waters, and from this part of the northern Pacific the current appears to flow mostly between the islands of Japan and the continent.

In the Indian Ocean, the effects of the tropical current, as it flows westward, are apparent in the southern deflection of the several isocrymes. The trend of thc coast favours a continuation of the current directly along the coast, and consequently, its modifying influence on the sea-temperature reaches almost to Cape Town on the coast, and passes even beyond it at sea, carrying $56^{\circ} \mathrm{F}$. to the meridian of $15^{\circ}$ east. 
By comparing the regions of the different oceans, north and south of the equator, we may arrive at the mean position of the several isocrymes, and thereby discover on a grander scale, the influence of the various oceanic movements.

For the purpose of reaching mean results, the Middle Pacific is the most favourable ocean for study. This is apparent in its greater extent, and the wide distance between the modifying continents; and also no less in the greater actual regularity of the isocrymes.

We hence deduce, that the mean position of the isocryme of $74^{\circ} \mathrm{F}$. is along the parallel of $20^{\circ}$, this being the average between the means for the North and South Pacific. In the same manner we infer that the mean position of the isocryme of $68^{\circ} \mathrm{F}$. is along the parallel of $27^{\circ}$.

The southern isocrymes of $56^{\circ}$ and $62^{\circ} \mathrm{F}$., are evidently thrown into abnormal proximity by the cold waters of the south. This current flows eastward over the position of the isocryme of $44^{\circ} \mathrm{F}$., and consequently in that latitude has nearly that temperature, although colder south. Hence, it produces little effect in deflecting the line of $44^{\circ} \mathrm{F}$.; moreover, the line of $50^{\circ} \mathrm{F}$. is not pushed upward by it. But the lines of $56^{\circ}$ and $62^{\circ} \mathrm{F}$. are thrown considerably to the north by its influence, and the Warm Temperate and Temperate Regions are made very narrow. With these facts in view, we judge from a comparison of the North and South Pacific lines, that the mean position for the isocryme of $62^{\circ} \mathrm{F}$. is the parallel of $32^{\circ}$; and for $56^{\circ} \mathrm{F}$., the parallel of $37^{\circ}$; for the isocryme of $50^{\circ} \mathrm{F}$., the mean position is nearly the parallel of $42^{\circ}$; for $44^{\circ} \mathrm{F}$., the parallel of $47^{\circ}$; for $35^{\circ} \mathrm{F}$., the parallel of $56^{\circ}$. There is thus a mean difference of five degrees of latitude for six degrees of Fahrenheit, excepting near the equator and between $35^{\circ}$ and $44^{\circ} \mathrm{F}$. These results may be tabulated as follows :*

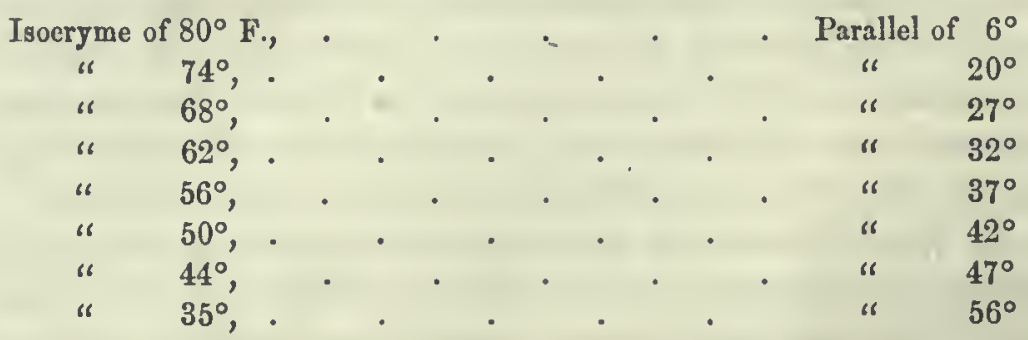

* We may hence deduce the temperatures of those isocrymes to which the parallels of latitude for every fire degrees would normally correspond. They would be for $20^{\circ}, 74^{\circ}$ $\mathrm{F}$.; for $25^{\circ}, 70^{\circ} \mathrm{F}$; ; for $30^{\circ}, 64.4^{\circ} \mathrm{F}$.; for $35^{\circ}, 58.4^{\circ} \mathrm{F}$; f for $40^{\circ}, 52.4^{\circ} \mathrm{F}$.; for $45^{\circ}$, $46.4^{\circ} \mathrm{F}$; ; for $50^{\circ}, 41^{\circ} \mathrm{F}$; ; for $55^{\circ}, 36^{\circ} \mathrm{F}$; ; for $60^{\circ}, 31^{\circ} \mathrm{F}$. 
Using these results as a key for comparison we at once perceive the great influence of the oceanic movements on climate and on the geographical distribution of marine life.

The polar current of the Southern Atlantic has a more northward course in mid-ocean than that of the Pacific. It consequently bears up the isocryme of $35^{\circ} \mathrm{F}$. to the parallel of $50^{\circ}$, six degrees above the mean. The effect on the other isocrymes of the Atlantic is very remarkable. We perccive in the first place that the most southern point of each of these isocrymes is not far from the mean position of the same isocrymes in the Pacific, while the most northern point of each is ten to twenty-five degrees farther north. Taking the position of the isccrymes of $68^{\circ}$ and $74^{\circ} \mathrm{F}$., where they cross the meridian of $15^{\circ}$ west, as the mean position for this occan, we find that the former is eight degrees in latitude farther north than $68^{\circ} \mathrm{F}$. in the South Pacific; and the mean for the latter is in $7^{\circ}$ south, while for the same in the Pacific it is $20^{\circ}$ south, making a difference of thirteen degrecs. The effect of the cold southern waters is consequently not along the African coast alone, but pervades the whole ocean. It is hence obvious, how utterly untenable the common notion, that the tropical current from the Indian Oeean is the same which flows up the west African coast. Witl a temperature of $56^{\circ}$ south of Cape Town, it would be wholly incapable of causing the great deflections for the whole South Atlantic which have been pointed out. It combines with the polar current, but does not constitute it. The facts thus sustain the opinions long since brought forward by the distinguished meteorologist Mr. Wm. C. Redfield, that the currents flowing north along the African and South American coasts are alike true polar or cold temperate currents.*

We may now turn to the North Atlantic. In this part of the ocean, the mean positions of the isocrymes of $74^{\circ}$ and $68^{\circ} \mathrm{F}$., are near the normal positions dedueed from the Pacifie. The line of $62^{\circ} \mathrm{F}$. is in a somewhat higher latitude, the mean position, excluding the eastern and western deflections, being near the parallel of $36^{\circ}$. The line of $56^{\circ} \mathrm{F}$. has the parallel of $422^{\circ}$ north for its mean position over the middle of the ocean, which is five and a half degrees above the normal in the Pacific. 'The line of $50^{\circ}$ has in the same manner for its mean position over the mid-ocean, the parallel of $47 \frac{1}{2}^{\circ}$, or again five and a

\footnotetext{
* American Journal of Science, xlv. 299, 1843.
} 
half degrees above the normal position in the Pacific. The line of $44^{\circ} \mathrm{F}$. may be considered as having for its mean position the parallel of $52^{\circ}$ north, while it rises to $60^{\circ}$ north. The lines in the North Atlantic above that of $68^{\circ}$, average about five degrees higher in.latitude than the mean normal positions, while $68^{\circ}$ and $74^{\circ}$ have nearly the same place as in the Pacific. There is hence a great contrast between the Pacific, South Atlantic, and North Ätlantic Oceans. This is seen in the following table containing these results:

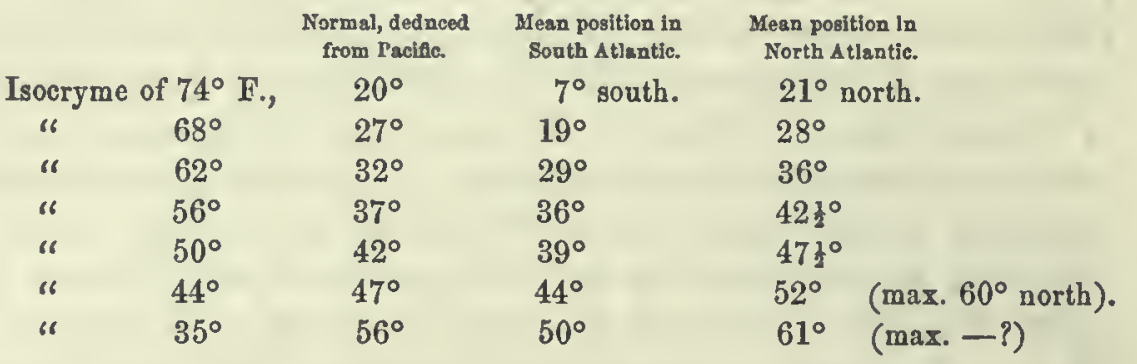

The influence of the warm tropical waters in the North Atlantic lifts the isocrymes of $74^{\circ}$ and $68^{\circ}$ as they approach the coast of America, while the same lines are depressed on the east by the colder northern currents. Moreover, north of $68^{\circ}$ the whole interior of the ocean is raised four to five degrees in temperature above the normal grade, by the same waters spreading eastward; and between Great Britain and Iceland, the temperature is at least ten degrees warmer than in the corresponding latitude of the South Pacific, and thirteen or fourteen degrees warmer than in the same latitude in the South Atlantic.*

The influence of so warm an ocean on the temperature of Britain, and on its living productions, animal and vegetable, is apparent, when it is considered, that the winds take the temperature nearly of the waters they pass over. And the effects on the same region, that would result from deflecting the Gulf Stream in some other direction, as remarked by Prof. Hopkinst and others, and substituting in the Northern Atlantic the temperature of the Southern Atlantic, is also

* Ross, in his Antarctic Voyage, found the sea-temperature in $60^{\circ}$ south and $3^{\circ}$ west, $313^{\circ} \mathrm{F}$, in the month of March; at the South Shetlands, $61^{\circ}$ south, the sea-temperature was $31^{\circ}$ to $35^{\circ}$ in January (midsummer); and in the same latitude, and $45^{\circ}$ west, it was $30.1^{\circ}$ in February.

† Quarterly Jour. Geol. Soc., vol. viii., p. 56, and Amer. Jour. Sci., 1853, vol. xv. 
obvious, without farther illustration. The discussion of these subjects would be foreign to the topic before us.

We close these general remarks, by giving the extreme surface temperatures of the waters, as nearly as ascertained, for some places of prominent importance in marine zoological geography. The extremes in view are the means of the coldest and warmest thirty consecutive days of the year.

\section{SOUTH AMERIOA.}

Venezuela and Surinam, $74^{\circ}-80^{\circ}$.

Pernambuco, $74^{\circ}-83^{\circ}$.

Bahia, $74^{\circ}-83^{\circ}$.

Rio Janeiro, $68 \frac{1}{2}^{\circ}-78^{\circ}$.

Buenos Ayres, $50^{\circ}-641^{\circ}$.

Rio Negro, $46^{\circ}-60^{\circ}$.

Fuegia, $36^{\circ}-56^{\circ}$.

Falklands, $37^{\circ}-50^{\circ}$.

Chiloe, $48^{\circ}-567^{\circ}$

Valdivia, $50^{\circ}-63^{\circ}$.

Conception, $52^{\circ}$ ? $-60^{\circ}$ ?

Valparaiso, $52^{\circ}-62^{\circ}$.

Copiapo, $56 \frac{1}{2}^{\circ}$ (July)-68 ${ }^{\circ}$ ?

Iquique, $58^{\circ}$ (July) $69^{\circ}$ ?

Callao, $57 \frac{1}{2}^{\circ}-74^{\circ}$.

Payta, $60^{\circ}-74^{\circ}$ ?

Guayaquil, $69^{\circ}-81^{\circ}$.

Gallapagos, $62^{\circ}-80^{\circ}$.

NORTH AMERICA.

Panama, $74^{\circ}-85^{\circ}$ ?

San Francisco, $51^{\circ}-68^{\circ}$ ?

Monterey, $54^{\circ}-70^{\circ}$ ?

Acapuleo $822^{\circ}-84^{\circ}$ (March).

Columbia River, $46^{\circ}-60^{\circ}$ ?

Puget's Sound, $42^{\circ}$ ? $-57^{\circ}$.

South of Newfoundland, $35^{\circ}-63^{\circ}$.

Massachusetts Bay, $37^{\circ}-64^{\circ}$.

Cape Henry, $46^{\circ}-80^{\circ}$.

Off Charleston, $64^{\circ}-81^{\circ}$.

Key West, $72^{\circ}-85^{\circ}$.

Yucatan, $71^{\circ}-83^{\circ}$.

Cuba, $74^{\circ}-84^{\circ}$.
GREAT BRITAIN AND EUROPE.

Shetlands, $36^{\circ}-56^{\circ}$ ?

Scotland, west and north, $39^{\circ}-58^{\circ}$.

Irish Sca, $45^{\circ}-63^{\circ}$.

English Channel, $46^{\circ}-62^{\circ}$.

Cape Finisterre, $50^{\circ}-66^{\circ}$.

Near Gibraltar, $58^{\circ}-77^{\circ}$.

Azores, $60^{\circ}-73^{\circ}$.

Madeira, $62^{\circ}-75^{\circ}$.

Canaries, $64^{\circ}-75^{\circ}$.

Cape Verdes, $70^{\circ}-82^{\circ}$.

\section{AFRIOA.}

Sierra Leone, $78^{\circ}-85^{\circ}$.

Aseension, $72^{\circ}-78^{\circ}$.

St. Helena, $68^{\circ}-74^{\circ}$.

Table Bay, $54^{\circ}-68^{\circ}$.

Port Natal, $72^{\circ}-73^{\circ}$ (May).

\section{INDIAN OCEAN.}

Soùth end of Madagascar, $69^{\circ}-80^{\circ}$. Mauritius, $72^{\circ}-83^{\circ}$.

Entrance of Red Sea, $76^{\circ}-88^{\circ}$.

Keeling Island, $78^{\circ}-83^{\circ}$ (April).

Singapore, $74^{\circ}-84^{\circ}$.

Balabac, $77^{\circ}-85^{\circ}$.

Manilla, $79^{\circ}-85^{\circ}$.

North Luzon, $74^{\circ}-84^{\circ}$.

PACIFIO OCEAN.

Ladrones, $79^{\circ}-86^{\circ}$.

Salomon Islands, $77^{\circ}-85^{\circ}$. 
New Hebrides, $74^{\circ}-83^{\circ}$.

New Caledonia, $73^{\circ}-82^{\circ}$.

Hawaiian Islands, $68^{\circ}-83^{\circ}$.

Kingsmills, $80^{\circ}-88^{\circ}$.

Feejees, $74^{\circ}-85^{\circ}$.

Tongatabu, $74^{\circ}-82^{\circ}$.

Samoan Islands, $74^{\circ}-85^{\circ}$.

Tahitian Islands, $74^{\circ}-83^{\circ}$.

Hervey Islands, $68^{\circ}-76^{\circ}$.

Island of Hawaii, $72^{\circ}-83^{\circ}$.

NEW HOLLAND, ETC.

Port Jackson, $55^{\circ}-71^{\circ}$.

Hobarton, Van Diemens Land, $50^{\circ}-60^{\circ}$.

Bay of Islands, N. Z., $54^{\circ}-67^{\circ}$.

King George's Sound, $58^{\circ}-68^{\circ}$.

A great service will be conferrcd on science when an isothermal chart for the continents is made out, with the most convenient subdivisions for illustrating the subject of the geographical distribution of land and fresh-water species. Dove's charts contain in part the elements as regards temperatures; but it remains to be decided which isothermal boundary lines had best be adopted for this particular purpose; and moreover, the actual curves of the isothermals dependent on the elevations of a country should be laid down. The winter lines of $68^{\circ}$ and $74^{\circ}$ for the ocean and air, appear to correspond very nearly, and the same lines might be used for the land chart as well as the marine. The former is the limit for the Cocoanut Palm as well as for coral-reefs, and the Torrid zone of oceanic temperature, might hence be called the Cocoanut-palm as well as the Coral-reef zone.

Temperature at depths.-With respect to.the change of temperature. as we descend in the ocean, we cannot present a series of facts, as those that have becn ascertained are too few and isolated to be of much service. The lowest temperature renched is $39 \frac{1}{2}^{\circ} \mathrm{F}$., which is less than that of the Frigid Region, as here laid down. Under the equator this temperature is not reached short of sevell thousand feet, and somewhere between the parallels of $45^{\circ}$ and $60^{\circ}$, the position varying with the seasons and meridian, it is found at the surface as well as at all depths below.

It is a question of much interest, how far temperature influences the range of zoological species in depth. From a survey of the facts relating to coral-zoophytes, the author arrived at the conclusion, that this cause is of but secondary importance.* After detcrmining the limiting temperature bounding the coral-reef seas, and ascertaining

* Exped. Report on Zoophytes, 1846, p. 103; and on Geology, p. 97. 
the distribution of reefs, it was easy to eompare this temperature with that of the grcatest depths at which the proper reef corals oeeur. This depth is but one hundred feet. Now the limiting temperature, $68^{\circ}$, is renehed under the equator at a depth of five hundred feet, and under the parallel of $10^{\circ}$ at a depth of at least three hundred feet. There must, therefore, be some other eause besides temperature; and this may be amount of pressure, of light, or of atmospherie air dissolved in the waters.

Prof. Forbes has remarked that the deep-sea speeies in the Egean have a boreal character;* and Lieut. Spratt, also, has aseertained the temperatures at different depths, $†$ and shown that the dcep-sea speeies are those which have the widest range of distribution, most of them occurring north, about the British shores or north of Franee. Yet is it true that the species whieh oeeur in decp watcr in the Egean are found in shallow waters of like temperature about the more northern eoasts? If so, Lieut. Spratt's conelusion, that temperature is the principal influenee which governs the distribution of marine fauna, in depth as well as in latitudinal distribution, will stand as true. But we believe that faets do not bear out this eonelusion. Deep-sea species live in deep seas in both regions, with but little differenec in the depth to which they extend. They are boreal in eharaeter, when of Mediterranean origin, because they are cold-water speeies; and their wide distribution is because of the wide range of temperature for which they are fitted, rather than their fitness to cndure a given temperature, which they find at considerable depths to the south, and near the surface to the north.

As this point is one of much importance, we have run over the reeent tables of dredging by Prof. E. Forbes, in the Egean and about the British Islands, to see how far it is borne out; and we add other results by R. MacAndrew, Esq., at Vigo Bay, Portugal, Gibraltar, Malta and Pantellaria, Algiers and Tunis.§

The great eare and thoroughness of Prof. Forbes's researches and those also of MacAndrew, give peculiar weight to the eonclusions. Those species are taken from the tables whieh are eommon to these

* Report on the Egean Invertebrata, Rep. Brit. Assoc., 1843, 130.

† Rep. Brit. Assoc:, 1848, 81.

† Rep. Brit. Assoc., 1843; and on British Marine Zoology, ibid., 1850, 192.

$\S$ Rep. Brit. Assoc., 1850, p. 264. 
several regions, and with regard to whieh the observations are free from doubt; and we have eonfined the list to the Acephalous molluscs, as these appear to be sufficient to test the law under diseussion. The depth is given in fathoms.

It should be observed, that to earry out the theory, the speeies should be confined to shallower waters to the north than to the south.

\begin{tabular}{|c|c|c|c|c|c|c|c|}
\hline & $\begin{array}{c}\text { North Scot. } \\
\text { land and } \\
\text { Shetiand. }\end{array}$ & $\begin{array}{l}\text { South Eng- } \\
\text { land and I. } \\
\text { of Man. }\end{array}$ & Vigo Bay. & Cibraltar. & Agean. & $\begin{array}{c}\text { Malts and } \\
\text { ''antei- } \\
\text { laria. }\end{array}$ & $\begin{array}{l}\text { Algiers } \\
\text { and } \\
\text { Tunis. }\end{array}$ \\
\hline 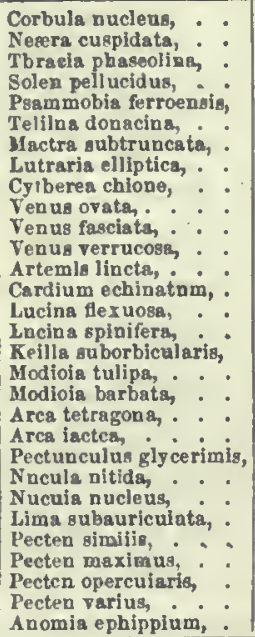 & $\begin{array}{c}3-80 \\
10-80 \\
0-80, \\
7-100 \\
3-90 \\
1-80 \\
0-12 \\
0-10 \\
8-100 \\
5-100 \\
5-90 \\
0-80 \\
0-100 \\
3-100 \\
10-100 \\
0-90 \\
10-50 \\
10-60 \\
\dot{0} \\
\dot{5}-80 \\
5-60 \\
5-100 \\
4-100 \\
2-80 \\
2-40 \\
2-100 \\
3-20 \\
0-80\end{array}$ & $\begin{array}{r}5-50 \\
50 \\
3-30 \\
5-50 \\
5-50 \\
5-40 \\
0-20 ? \\
0-20 \\
10-20 ? \\
7-50 \\
7-50 \\
0-10 \\
5-50 \\
5-50 \\
5-50 \\
15-30 ? \\
10-40 \\
5-25 \\
2-15 \\
20-30 \\
10-50 \\
5-50 \\
5-30 \\
5-50 \\
15-30 \\
20-30 \\
10-30 \\
5-50 \\
3-30 \\
0-50\end{array}$ & 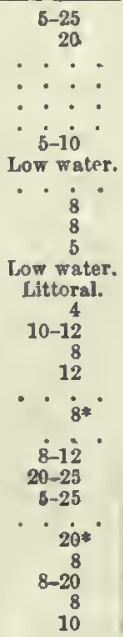 & 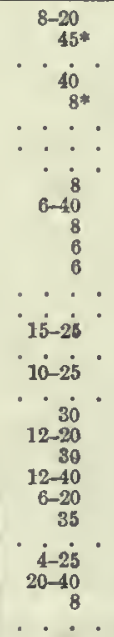 & $\begin{array}{c}7-80 \\
12-185 \\
7-30 \\
20-40^{\circ} \\
7-45 \\
\vdots \\
7-10^{\circ} \\
29-135 \\
27-40 \\
2-40 \\
7-50^{\circ} \\
7-11 \\
4-30 \\
29-45 \\
2-50 \\
7-95 \\
20-80 \\
0-150 \\
6-24 \\
2-10^{\circ} \\
15-30 \\
27-185 \\
10-70^{\circ} \\
7-55 \\
20-40\end{array}$ & $\begin{array}{c}6-50 \\
\vdots \vdots: \\
\vdots \vdots: \\
\vdots\end{array}:$ & 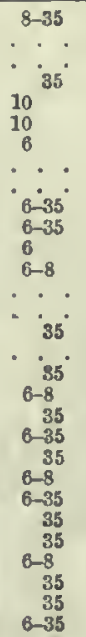 \\
\hline
\end{tabular}

To eompare fairly this table, it should be noted that the dredging at the Shetlands, Orkneys, and north of Scotland, was carried to a greater depth than about Southern England, fifty fathoms being the limit in the latter region, as the waters are shallow. Making this allowance, we are still struek with the great depth to which the speeies penetrate at the most northern loeality, instead of the small depth. Out of the twenty-one speeies whieh are here mentioned as oeeurring on Northern Scotland, or the Shetlands, and the Agean, fourteen or fifteen descend to a greater depth in the former than in the latter; and nearly all the species eommon to the north and south extremities of the British Islands, are reported from the deepest waters at the north. Of the observations made at Vigo Bay, Malta, Pantellaria, Tunis, Algiers, and Gibraltar, there is but a single example among the above speeies of a greater range in depth than oeeurs in the northernmost locality examined. The dredging in the Mediterranean by MaeAndrew, was not carried to as great depths; yet even allowing for this,

* Not found living at the depth stated. 
the facts are not a littlc remarkable. One hundred fathoms appears to have been the greatest depth of the Shetland dredgings.

Now the temperature in the Asgean during the warmer months, according to Lieut. Spratt, is as follows:-

\begin{tabular}{|c|c|c|c|c|c|c|}
\hline \multicolumn{2}{|c|}{ At the surface, } & \multicolumn{5}{|c|}{$76^{\circ}-81^{\circ}$} \\
\hline 10 & futhoms, & seldom & below & $74^{\circ} \quad$ in & in the & summer. \\
\hline 20 & "6 & " & " & $68^{\circ}$ & $" 6$ & " \\
\hline 35 & " & “ & " & $62^{\circ}$ & « & $"$ \\
\hline 75 & “ & " & “ & $56^{\circ}$ & "6 & 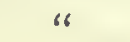 \\
\hline $100-300$ & $"$ & "6 & .6 & $55^{\circ}-551^{\circ}$ & $\circ "$ & "6 \\
\hline
\end{tabular}

The temperature of the waters near Southern England in summer is $62^{\circ}$; and near the Shetlands $55^{\circ}$ or less. Consequently the surface summer temperature of the British Channel is not found in the Egean at a less depth than thirty-fivc fathoms, and the surface summer temperature of the Shetlands, is the temperature at one to three hundred futhoms in the Eggean; and still species that range to a depth of one hundred fathoms about Northern Scotland are found within thirty fathoms of the surface in the Egean, that is, where the summer temperature is $74^{\circ}$ or more. Such facts-show the hardiness of the species in enduring great ranges in temperature. Wc must, therefore, conclude, that it is not temperature alone or mainly which determines the depth to which species may live. It exerts an influence, and species fitted for cold waters may be found in the deeper scas where such waters occur; but the limit of descent depends on other influcnces.

Looking at this table in another way, we see, as recognised by Prof. Forbcs, that species which occur at or near the surface in Northern Scotland, are generally met with only at greater depths in the Mediterranean; that is, the minimum depth is less in the former case than the latter. Thus Corbula nucleus has for its minimum depth in the Mediterranean six fathoms, and in the northern regions three fathoms. Psammobia ferroensis has ten fathoms for the former, and three for the latter. Other examples will be found in the above table, sufficient to illustratc the principle, although many exceptions exist. Thus species that have the range of one liundred fathoins beyond Scotland, may have the same in the Mediterranean, except that in many cases they do not reach as near the surface, where the waters are warm.

The Crustacea of the same seas illustrate this subject in a similar 
way. But the observations upon them have been made with less thoroughness, and we have, therefore, confined our discussions to Molluscs.

Prof. Edward Forbes has with much discrimination laid down certain zones in depth, and pointed out their zoological and botanical peculiarities for ccrtain coasts. The observations on Crustacea made by us, were not extended to any considerable, depth, and they will not enable us, therefore, to recognise these several zones in the following tables.

\section{GEOGRAPHICAL DISTRIBUTION OF SPECIES.}

In making an application of the isothermal oceanic chart to the subject of the geographical distribution of Crustacea, we have two objects before us.

First.-To compare the zones and their regions with one another as to (a) number of species, (b) number of genera, (c) number and size of individuals, (d) grade of species, in order to arrive at some general conclusions as to the temperatures best fitted for the highest and most prolific developments of Crustacea.

Second.-To compare different geographical positions in similar regions with one another, in order to arrive at their resemblances and differences, and deduce the several distinct zoological provinces; and also to distinguish the more or less wide diffusion of species in longitudinal range.

1. DISTRIBUTION OF CRUSTACEA WITH REFERENCE TO THE TEMPERATURE.

We here present a series of tables, containing, for each genus, the number of species that occurs in each temperature region, with a column also giving the sum of the Torrid zone species, and another for the sum of the Temperate zone species. The several regions arc lettered $a, b, c, d, \& c$., to $h$, and where one or more species in a region occur in another nearer the equator, it is indicated by annexing the number with the letter of the column in which it occurs. Thus, $6(2 a)$ in column $b$, means that there are six species in the $b$ or Subtorrid Region, but two of them are found also in the $a$ or Torrid Region. 
GEOGRAPHICAL DISTRIBUTION OF CRUSTACEA. 1489

We give first a table of the Brachyura, and following this, a recapitulation and summary, containing a summing up of the species for the subfamilies, families, tribes, \&c. These tables afford some obvious deductions. Then follow similar tables for the Anomoura, Macroura, and remaining Podophthalmia, with a series of deductions; and then the same for the Tetradecapoda.

The perfecting of the Temperature Chart, by changing the limits of some of the regions (which is to be expected as new facts are brought in), will undoubtedly cause some modifications of these tables; but nothing that will affect essentially the conclusions which will here be drawn from them. 
TABLE I.

B R A C H Y U R A.

1. MAIOIDEA.

\begin{tabular}{|c|c|c|c|c|c|c|c|c|c|c|}
\hline . & 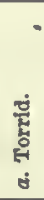 & 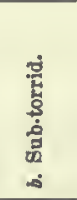 & 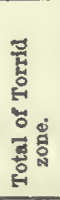 & 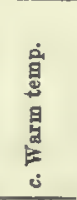 & 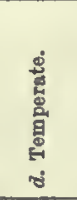 & 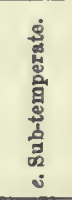 & 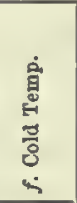 & 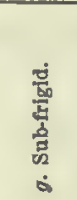 & 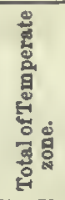 & 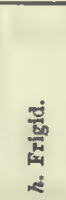 \\
\hline 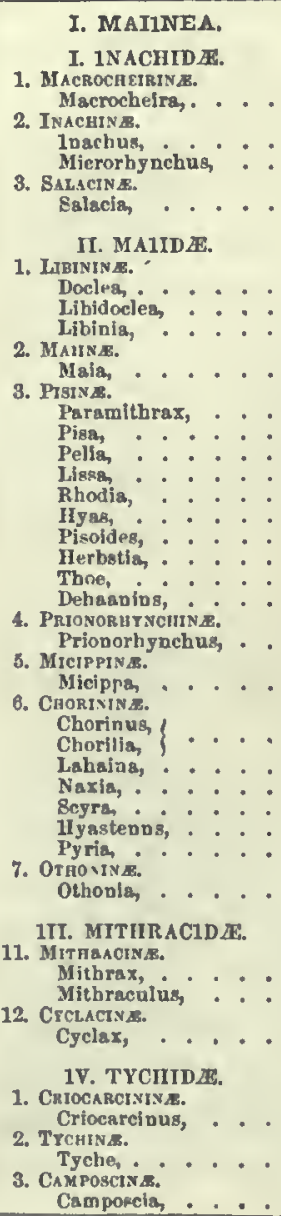 & $\frac{1}{3}$ & $\begin{array}{l}1(a) \\
2 \\
2(1 a) \\
\frac{1}{3}(a) \\
(1 a) \\
1\end{array}$ & $\begin{array}{l}2 \\
2 \\
1 \\
3 \\
1 \\
11 \\
11 \\
5 \\
7 \\
1 \\
1 \\
1 \\
1\end{array}$ & $\begin{array}{l}2(16) \\
1 \\
3 \\
1 \\
1 \\
1 \\
2 \\
1\end{array}$ & $\begin{array}{l}1 \\
1 \\
2(1 \mathrm{c}) \\
1 \mathrm{q} \\
4(2 \mathrm{c}) \\
1 \\
1(1 \mathrm{c})\end{array}$ & $1(c)$ & $\begin{array}{l}1 \\
3(10) \\
\end{array}$ & $\begin{array}{l}1 \\
1(c) \\
1 ! \\
1(e)\end{array}$ & $\begin{array}{l}1 \\
2 \\
4 \\
3 \\
4 \\
4 \\
1 \\
1 \\
1 \\
3 \\
1 \\
3 \\
1 \\
1\end{array}$ & $1(f)$ \\
\hline
\end{tabular}


GEOGRA P.HICAL DISTRIBUTION OF CRUSTACEA. 1491

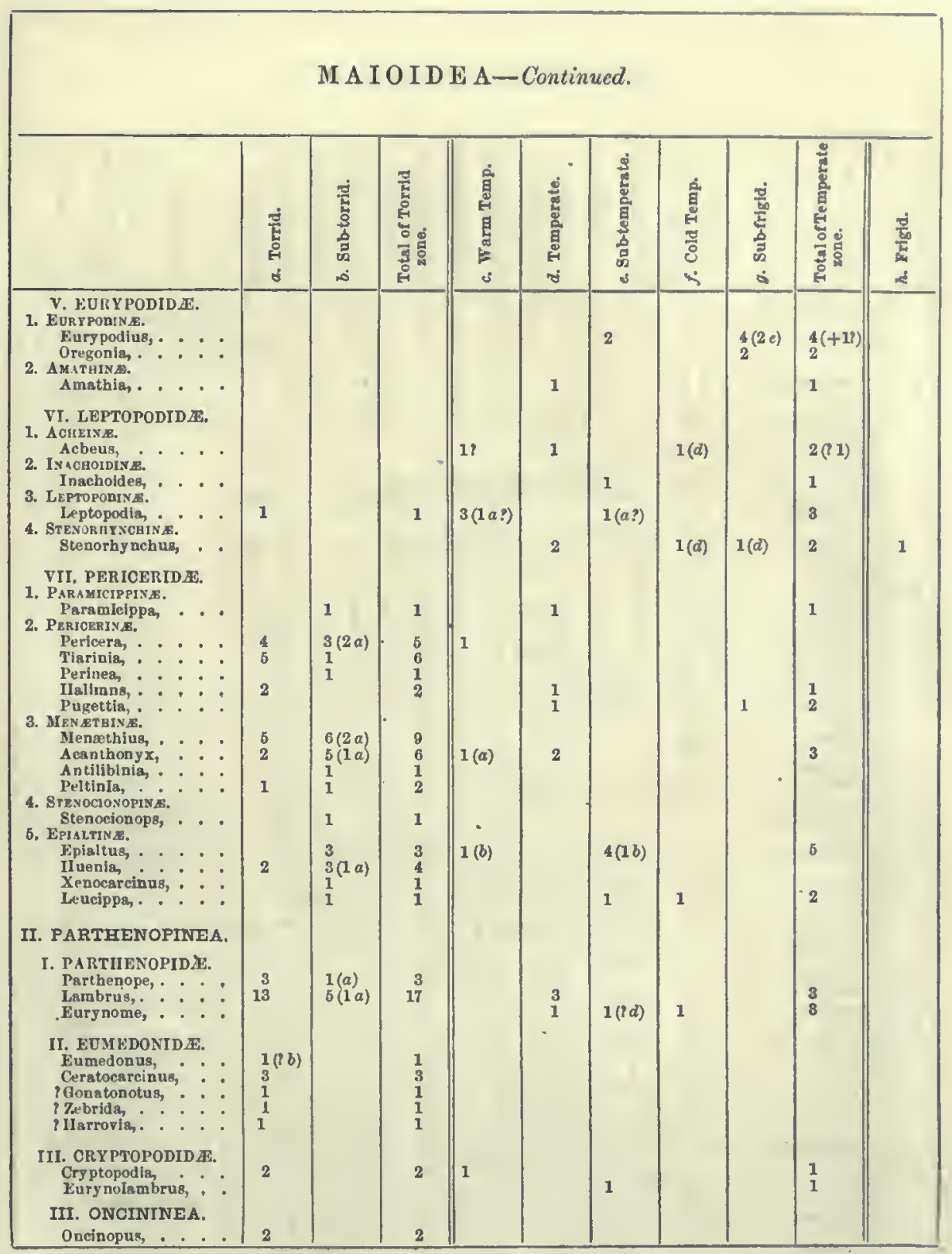




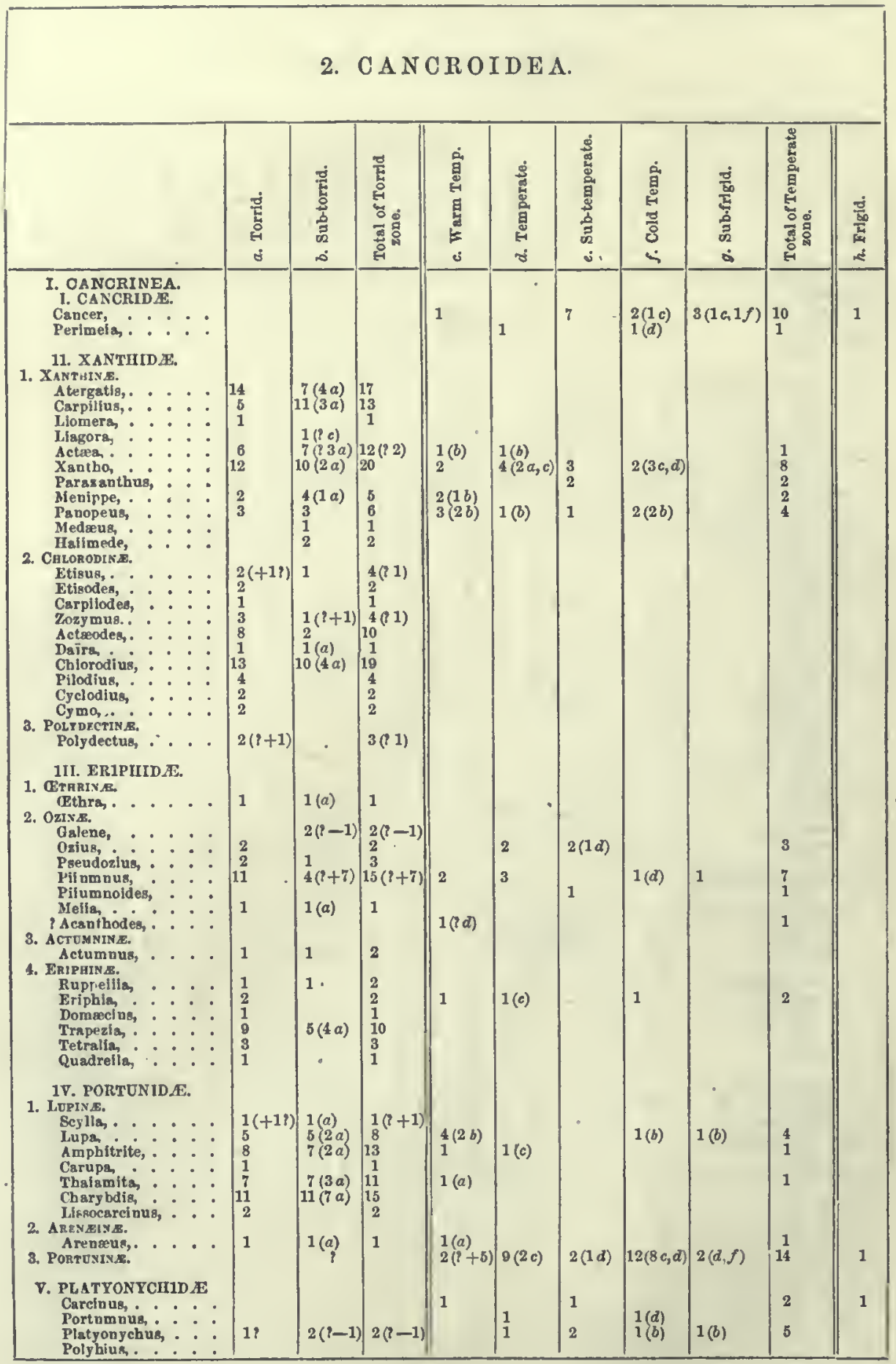


GEOGRAPHICAL DISTRIBUTION OF CRUSTACEA. 1493

\begin{tabular}{|c|c|c|c|c|c|c|c|c|c|c|}
\hline \multicolumn{11}{|c|}{ C A N C R O I D A-Continued. } \\
\hline & $\begin{array}{l}\text { 爮 } \\
\text { : } \\
\text { s. }\end{array}$ & 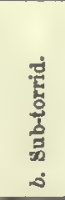 & 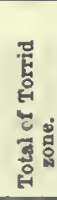 & 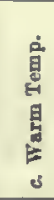 & 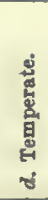 & 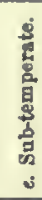 & 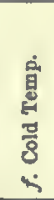 & 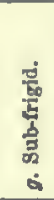 & 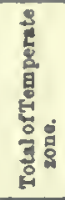 & 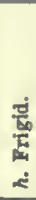 \\
\hline $\begin{array}{l}\text { VI. PODOPIITILALMIDE. } \\
\text { Podophthalmug, } \\
\text { II. TELPHUSINEA." } \\
\text { III. CYCLINEA. } \\
\text { Acanthocyclus, . }\end{array}$ & 2 & $1(a)$ & 2 & & & 1 & & & 1 & \\
\hline
\end{tabular}

3. GRA PSOIDEA.

\begin{tabular}{|c|c|c|c|c|c|c|c|c|c|c|}
\hline & 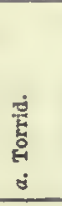 & 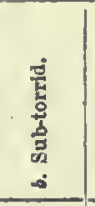 & 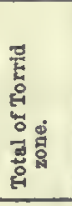 & 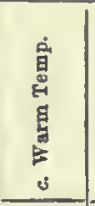 & 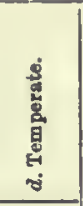 & 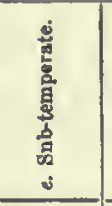 & 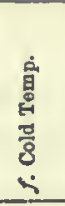 & $\begin{array}{l}\text { 悹 } \\
\text { 营 } \\
\dot{5} \\
\dot{5} \\
\dot{a}\end{array}$ & 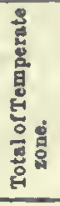 & 렬 \\
\hline 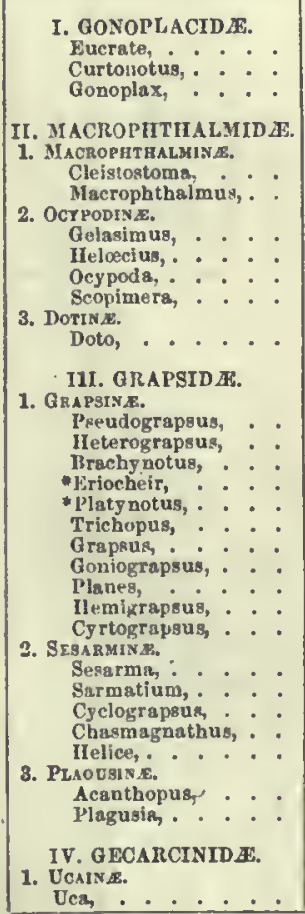 & $\begin{array}{c}2 \\
7 \\
10 \\
8 \\
1\end{array}$ & \begin{tabular}{|l} 
\\
2 \\
1 \\
1 \\
$1(a)$ \\
$5(3 a)$ \\
$8(2 a)$ \\
2 \\
$4(1+1)$ \\
\\
$11(3 a)$ \\
3 \\
$2(1 a)$ \\
$1 ?$ \\
$1(a)$ \\
$3(1 a)$ \\
0
\end{tabular} & $\begin{array}{r}5 \\
12 \\
16 \\
13 \\
1 \\
1 \\
\\
1 \\
\\
3 \\
1 \\
1 \\
7 \\
8 \\
2 \\
4\end{array}$ & $\left|\begin{array}{l}3(3 a, b) \\
2(2 a b) \\
2(1 b) \\
\\
3(2 b)\end{array}\right|$ & $\begin{array}{l}1(a) \\
2(1 b) \\
1(b) \\
2(i e)\end{array}$ & $\begin{array}{l}2(1 a) \\
2 \\
1(b) \\
\frac{1}{2}(l+1 a) \\
\frac{1}{2(a)}(1 a)\end{array}$ & $\begin{array}{l}1(b) \\
1 \\
1\end{array}$ & $1(b)$ & $\begin{array}{l}5 \\
3 \\
2 \\
5 \\
1\end{array}$ & \\
\hline
\end{tabular}

374 
G R A P S O I D E A-Continued.

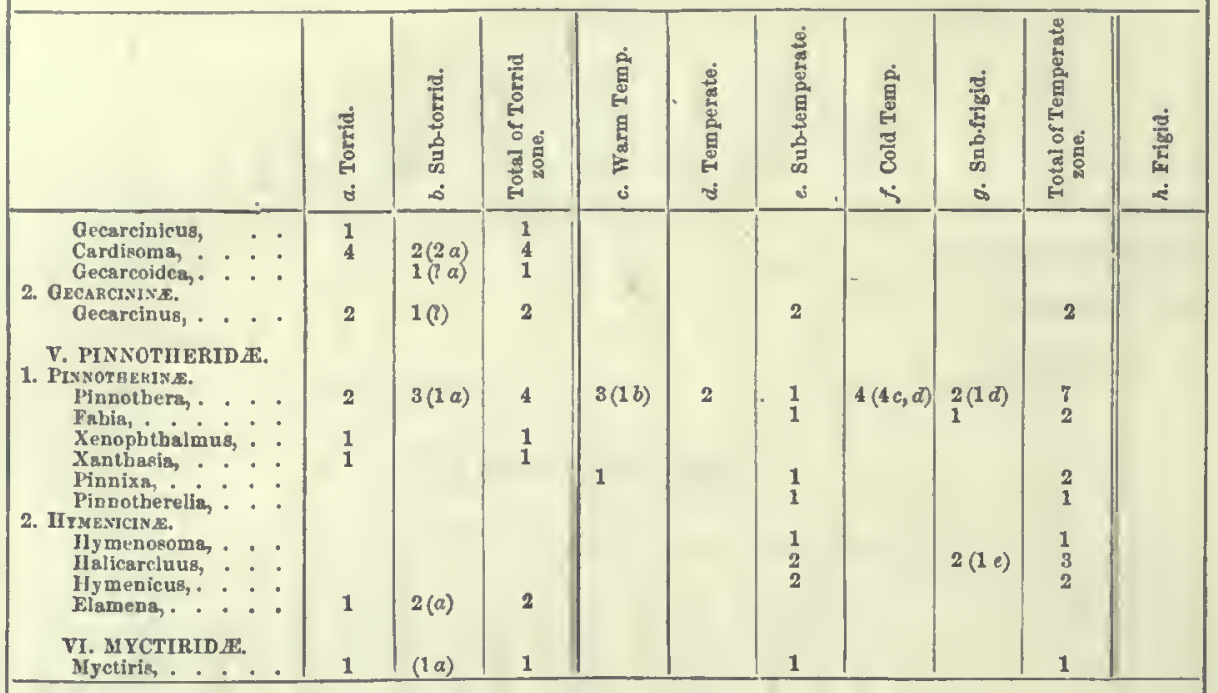

\section{LEUCOSOIDEA.}

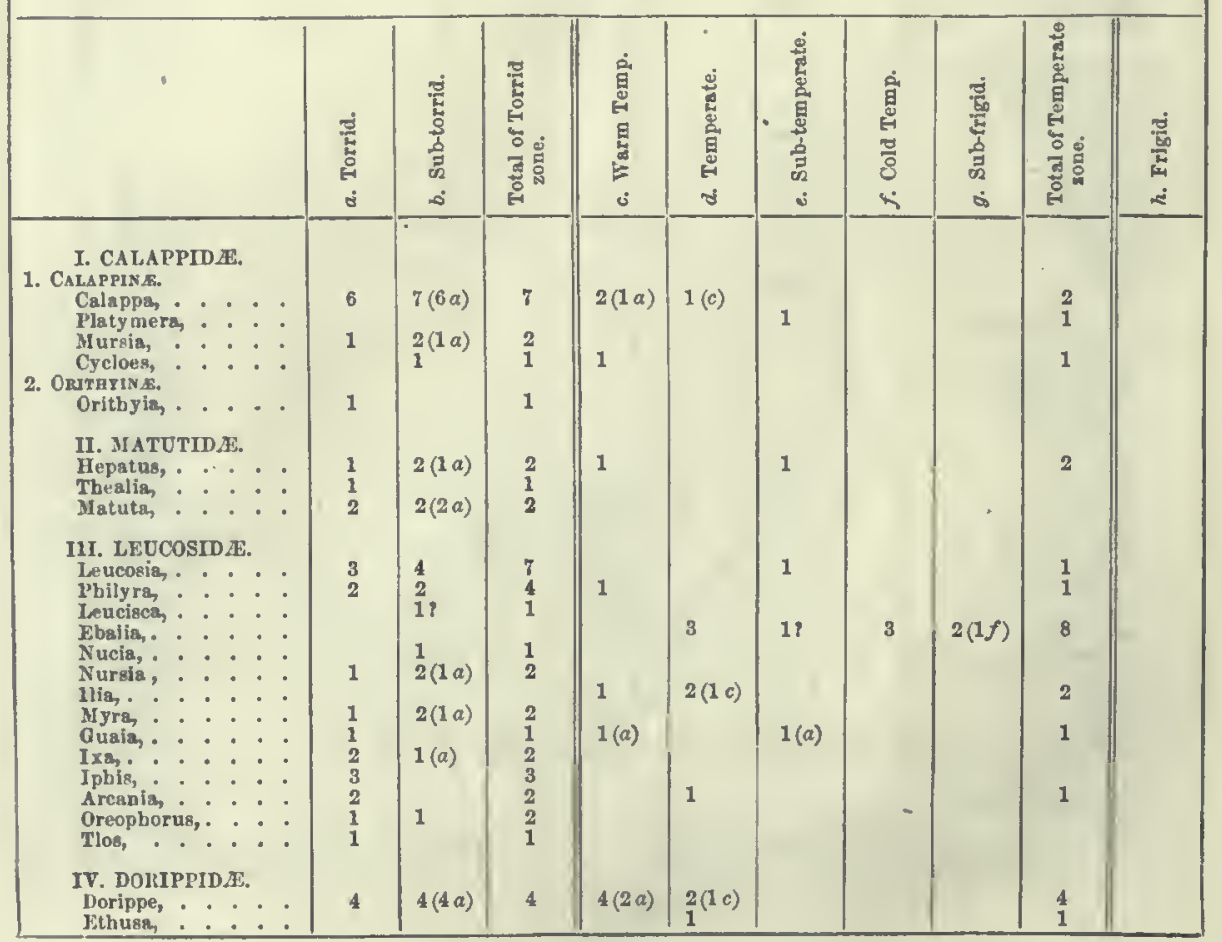




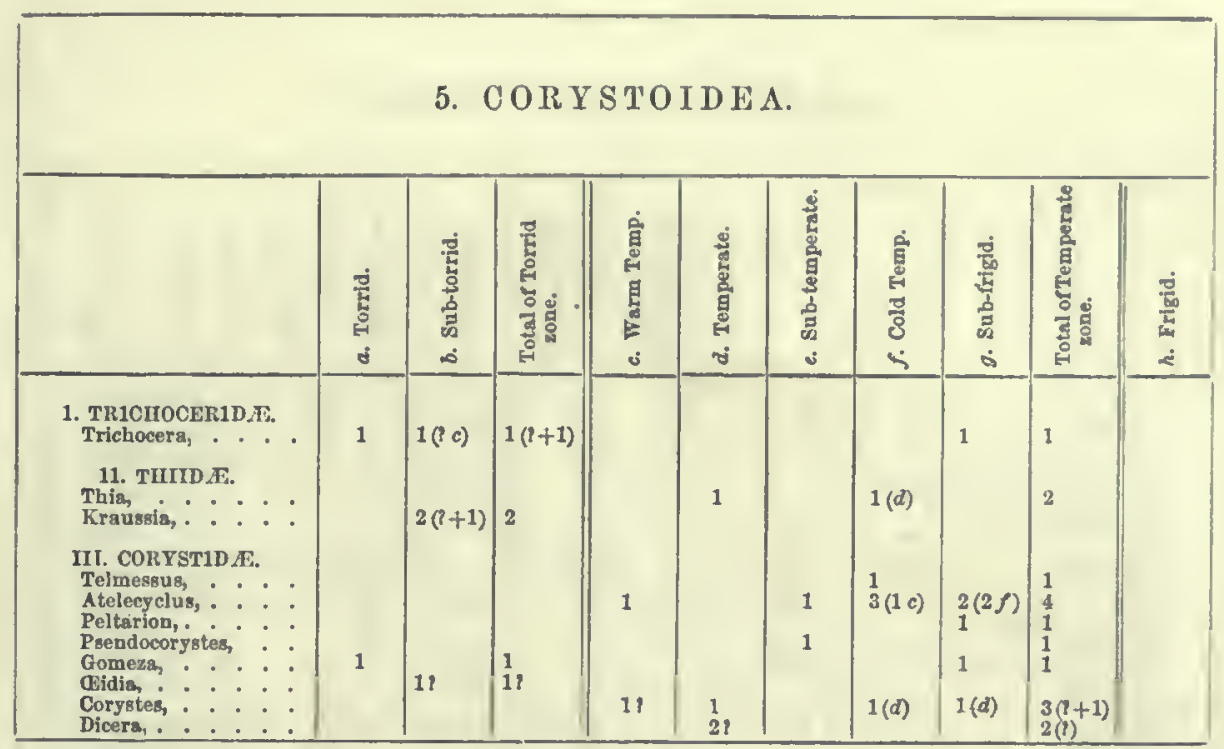

In the following recapitulation, the figure in parenthesis following the Total for the Temperate zone of the larger groups, expresses the number of species common to the Temperate and Torrid zones. 


\section{RECAPITULATION.}

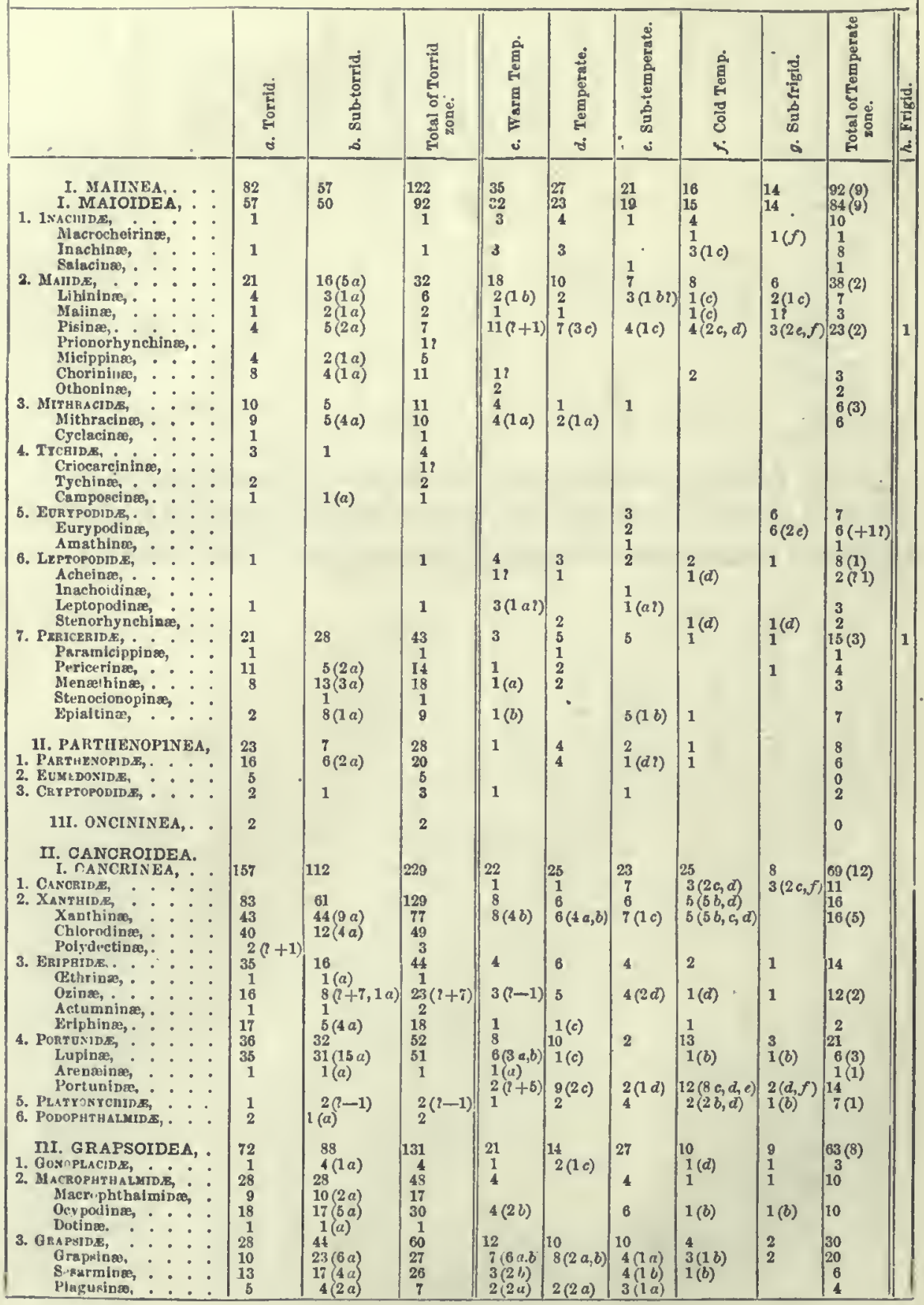




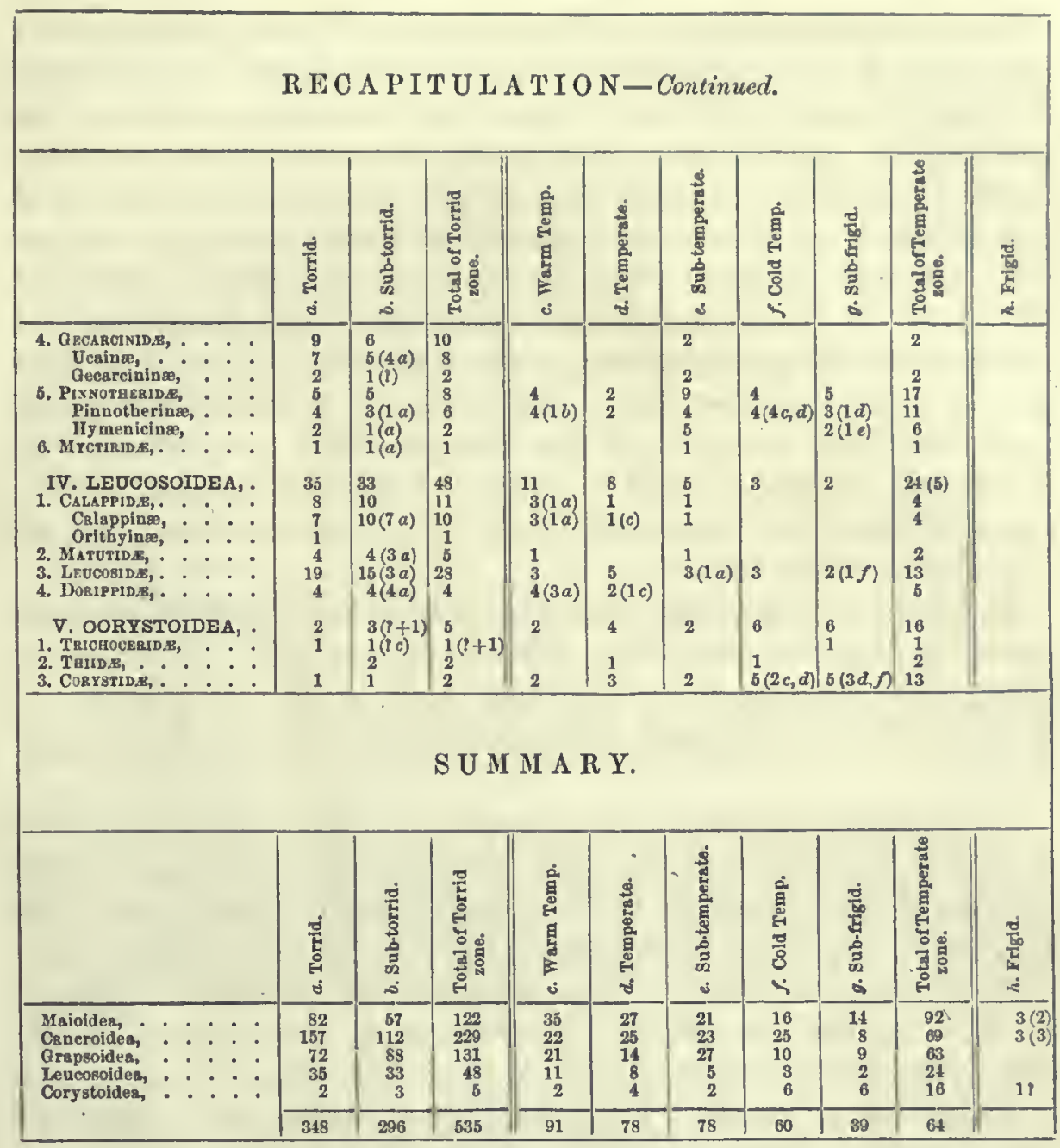

We here notice a few of the general facts or conclusions that may be deduced from the preceding tables.

I. The line of division, separating the Torrid and Temperate zones of ocean temperature, following the isocryme of $68^{\circ}$ or the outer limit of coral reef seas, marks a grand boundary in organic life, well exemplified in Crustacean species. Out of the five hundred and thirty-four species of the Torrid and Subtorrid Regions (the Torrid zone), there are one hundred now known to be common to the two. But of the two hundred and fifty-four in the Temperate Regions, only thirty-four occur in the Torrid zone. A large number of genera, containing more than a single known species, are confined wholly to the Torrid zone: 
suclı are Micippa (5 species), Menæthius (9), Huenia (4), Parthenope (3), Atergatis (17), Carpilius (13), all the Chlorodina, including fortynine species, nearly all the Eriphinæ, including eighteen species, Charybdis (15). At the same time, the species of the Torrid and Subtorrid Regions are in many cases equally numerous. Of species of Charybdis, eleven species occur in each of these regions; of the Carpilii, eleven are reported from the Subtorrid and but five from the Torrid; of the Menæthii, five are found in the Torrid Region, and six in the Subtorrid, only two being common to both. These proportions may be much varied by future investigations. Still it cannot fail to be evident from a survey of the table, that the line between the Torrid and Temperate zones is a natural zoological limit. A further examination of the other subdivisions, will show, we believe, that all of them are important.

II. The Torrid species of Brachyura (Torrid and Subtorrid Regions) greatly preponderate over those of the Temperate zone, the proportion being above two to one. This fact is the subject of remarks by Edwards, but with different conclusions from those which we would deduce.

III. The Frigid zone, as far as known, includes one species peculiar to it, the Chionoecetes opilio. And Stenorhynchus phalangium, Hyas araneus, Portunus pusillus, Carcinus monas, and Cancer pagurus, are all that are known to extend into it from the Temperate zone. Perhaps the Cancer chirogonus from Kamtschatka (Telmessus chirogonus of White) should be added. This may be in part evidence of the little exploration hitherto made in the Frigid Seas. Yet, after the investigations of Beechey, Fabricius, Kröyer, Rathke, and others, we may be assured that the number of species is exceedingly small.

IV. Within the Temperate zone, the species are most numerous in the Warm Temperate, Temperate, and Subtemperate Regions; beyond this, the number diminishes, being a quarter less in the Cold Temperate than in the Subtemperate, and half less in the Subfrigid. Moreover, in the last-mentioned region, seventeen out of the thirty-seven species, or nearly one-half, occur in warmer temperate latitudes, only twenty species being confined to the Region.

$\mathrm{V}$. In the Torrid zone, the species of the torrid region, amounting to three hundred and forty-eight, exceed in number those of the Subtorrid by only forty-two, although the Subtorrid region is not onethird as great, both as to surface and extent of coast line. 
VI. Passing now from these general considerations respecting the Brachyura as a class to the several orders, we may look at their ratios among these orders and thcir subdivisions, for the several regions, in order to discover what is the relation of the species to temperature, and whether the cold or warm water species are the higher or lower in grade, or whether the torrid or temperate zone can claim species of the highest perfection or magnitude among the Brachyura.

The following table gives the ratio which the number of species of the several orders in the Temperate and Frigid zones, bears to that of the Torrid zone.

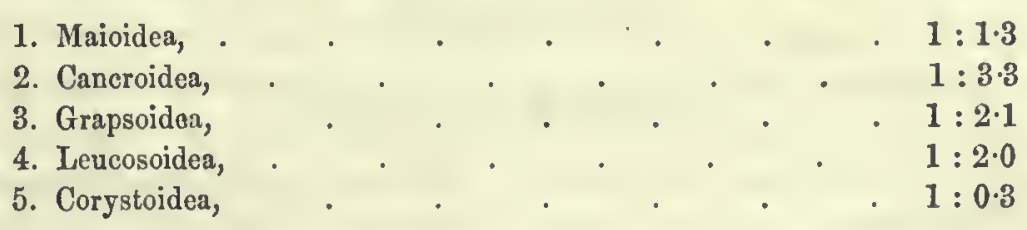

It hence appears that the Maioidea and Corystoidea are proportionally much more abundant in the colder seas than the Cancroidea, Grapsoidea, or Leucosoidea.

If we examine into the subdivisions of the Maioidea and Cancroidea, we shall find the differences between the two groups in distribution more strikingly brought out. We shall find, moreover, that both groups may be divided into a warm-water and cold-water section, as below.

\section{MAIOIDEA.}

1. TEMPERATE ZONE SECTION.
1. Inachidx,
$\underset{\text { Torrid }}{\text { species. }}$ Temperato
specios.
2. Maiidx, subfamilics Libininæ, Maiinæe, Pisinæ, Otho- ninæ, . 1535
3. Eurypodidx,
4. Ireptopodidx,

\begin{tabular}{rr}
15 & 35 \\
0 & 7 \\
1 & 8 \\
\hline 17 & -60
\end{tabular}


2. TORRID ZONE SECTION.

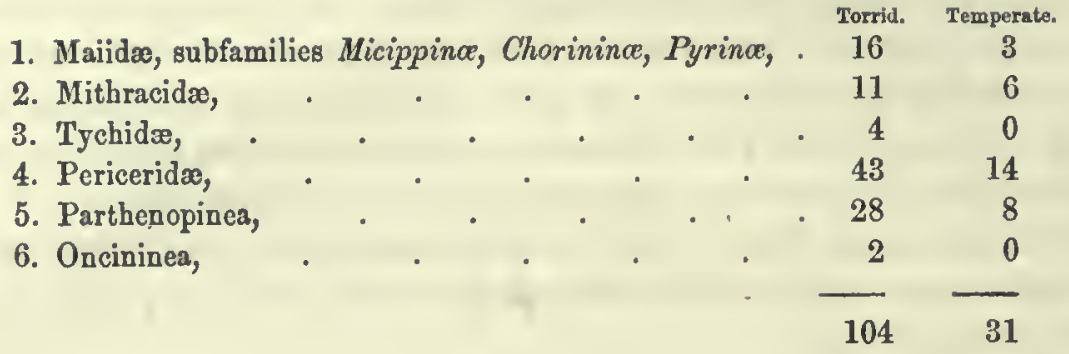

II. CANCROIDEA.

1. TEMPERATE ZONE SECTION.

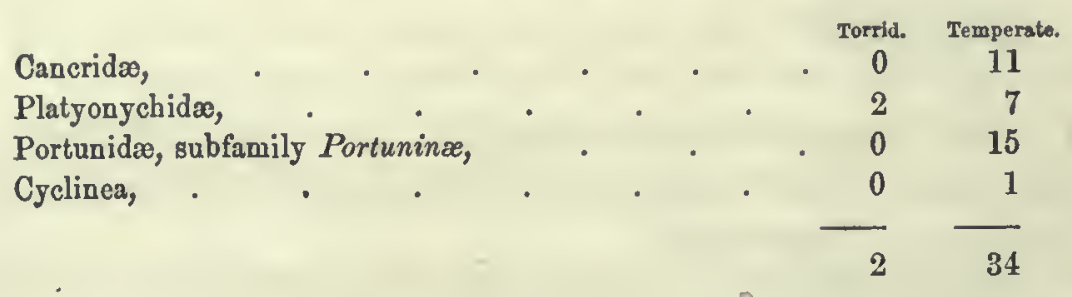

2. TORRID ZONE SECTION.

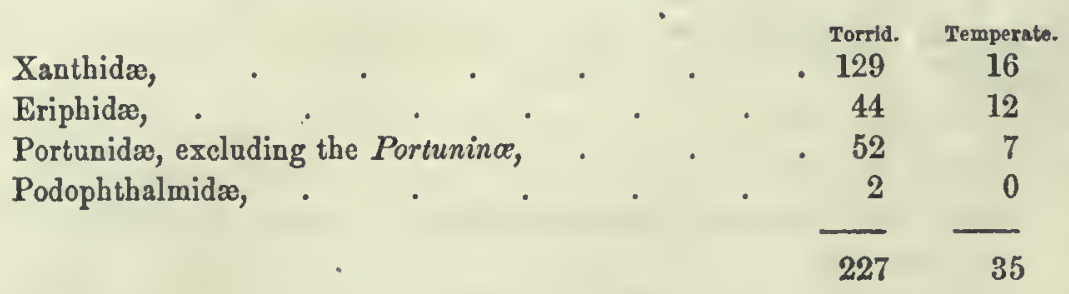

We have here two singular facts brought out.

First, that the cold-water section of the Cancroidea embraces those species that approach most nearly to the Corystoidea, and which we have elsewhere shown to be the lowest in grade of the Cancrinea. All have the lax character of the outer maxillipeds, which is a mark of degradation in the Corystoids; and the Cyclinea are still nearer that group. Many of the species moreover have the hind legs a swimming pair, another mark of degradation. The Corystoidea, as before shown, are two-thirds cold-water species.

Second, that the cold-water section of the Maioidea contains the 
specics that are highest in grade, and largest in size. It is headed by the Macrocheira of Northern Japan, the king of all crabs, whose body is seventeen inches long and a foot broad, or, with extended legs, sometimes covers a breadth of eleven feet, and whose anterior legs or arms are four feet long !* The species of the other genera are mostly among the larger of the Maioids, and have no mark of inferiority. Such are the species of Maia, Pisa, Libanii, Eurypodius, ctc.

But among the species of the warmer section, we find the Oncininea and Parthenopinea, both manifestly inferior in grade, the former approaching even the Anomoura, and the latter forming the passage of the Maioids to the Cancroids, as has been explained. We observe also the Periceridx and Tychidx, all very small species, excepting a few Periceræ: the Menæthii, Tiarinix, and Acanthonyces, are examples of the group. In addition, there are the Mithracida, which although attaining a large size show their inferiority in their shorter epistome, shorter body, which is sometimes even transverse, and their spoonshaped fingers. In the last character, the Chlorodina among the Cancroids, similarly show their inferiority to the Xanthidx. That this kind of finger is such a mark of inferiority is apparent from its diminishing in many species as the adult size of the animal is attained, the tendency being towards producing the acuminated finger found in the highest grades.

We are hence sustained in the conclusion that the Maioids of the Temperate zone are generally those that are highest in grade. It also shows the congeniality of cold waters to the Maioids, that the only Brachyuran peculiar to the Frigid zone is of this group. We refer to the Chionoecetes opilio.

VII. The Brachyura, therefore, although most numerous in the Torrid zone, do not reach in this zone their highest perfection. On the contrnry, the Temperate zone or colder waters are the habitat of the highest species. Hence, as the Maioidea stand first among all Crustacea, the highest development of the class Crustacea takes place, not in the Torrid zone, the most profuse in life, but beyond the tropics and coral-reef seas, in the middle Temperate Regions.

VIII. The prevalence also of the inferior Corystoids in the colder waters does not invalidate this conclusion, as the fact respecting the Maioids is wholly an independent one; for these last, by attaining

* De Haan's Fauna Japon., Crust. p. 101. 376 
their highcst perfection in these coldest waters, determine the principle as regards themsclves, the highest grade of Crustacea. Lower grades occur also in the colder waters; and the laws governing their distribution demand separatc study and consideration.

IX. Passing a step below the Maioids, we come to the Cancroids, and these, with the exception of the lower Corystoid species, and only one-eighth of the rest, arc Torrid zone species.

$\mathrm{X}$. If the Torrid zone is the proper region for the full development of the Cancroid typc, and its heat is needed for this end, it is natural that species of Cancroids like the Portunino, Platyonychidoe, and Cancrida, found in the less genial waters of the Temperate zone, should bear some mark of inferiority, and it is a fact that they have such marks in their structure. This inferiority is not seen in their smaller size, for a larger size, under certain conditions, may equally evincc a lower gradc, but in the inferior concentration of the life-system, exhibited either in the lax outer maxillipeds, the elongation of the antennæ and abdomen, or in the smaller size or swimming character of the posterior legs.

For a like reason also, the species of Corystoidea, a grade still lower, naturally occur in the cold and ungenial region they frequent.

We hence perceive, that the degradation among the Maioids takes place when the species become warm-water species, and the degradation among the Cancroids, in the reverse manner, when the species become cold-water species; for the reason that the colder waters are the proper habitat for the Maioid type, and the warmer for the Cancroid type.

XI. In the tables of the Maioidea and Cancroidca of the Tempcrate and Torrid zones, page 1499, the species are included by families and subfamilies, and consequently the peculiarities of some genera are not shown. In the families or subfamilies referred to the cold-water section, there is only one warm-water genus, viz., Doclea, of the subfamily Libinina, in which there are four Torrid and one Temperate zone specics.

Among those referred to the warm-water section, there are the following cold-water genera :-

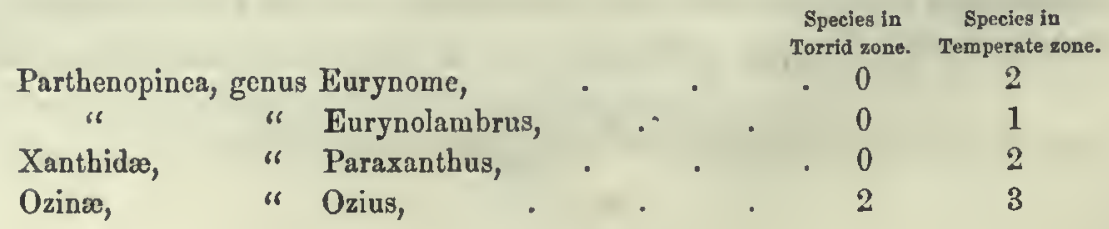


The species of Cancrinea of the Torrid zone section, which reach farthcst into the Temperate zone, are those of the following genera:Xantho, which has eight Temperate zone specics out of twenty-cight in all; Panopeus, which in the same way has four out of ten; Pilumnus, which has seven out of twenty-two; and Lupa, which has four out of ten. The Cold Tempcratc Region is the highest for each of these genera, excepting Lupa and Pilumnus, a spccies of each of these latter genera extending just within the limits of the Subfrigid Region, on the coast of Massachusctts.

XII. The Grapsoidea, if divided between the Torrid zone and Temperate zone, according to families or subfamilies, will fall within the Torrid zonc, exccpting a single family of thc Pinnotheridæ, which contains eight species in the Torrid zone and fifteen in the Temperate. Considering the genera, however, we find that sevcral among the Grapsida may be called cold-water genera, or are about equally divided between the Torrid and Temperate zones. They are as follows:

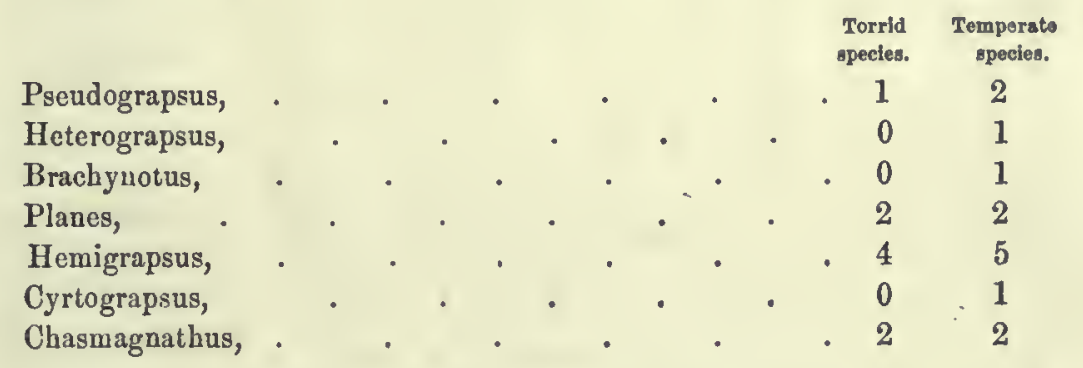

Five out of twelve species of Grapsus also reach into the colder seas. Further particulars will be gathered from the tables.

XIII. The Leucosoids include as cold-water genera the following :

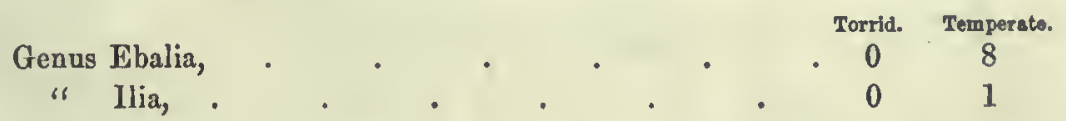

The remaining genera are mainly confined to the Torrid zone; out of the species they contain, sixty-seven in all, forty-eight are of this zone. Hepatus, howevcr, contains as many cold-water as warm-water species, and the same is true of Dorippe, although but one of the species of the latter is exclusively Tempcrate.

XIV. The tropics afford not only a larger number of species of Brachyura than the Temperate zone, but also a much greater propor- 
tion of individuals of the several species. Crustacean life, of this tribe, is far the most prolific in the warm waters of the globe. Crustacen are very abundant about coral islands, far exceeding what may be found in other regions.

$\mathrm{XV}$. The actual mass of Brachyura appears also to be the largest in the tropics, although there are genera, as Macrocheira and Cancer, which have their largest species in the colder waters, and which exceed in size any other Brachyura. The genera Atergatis, Carpilius, Xantho, Menippe, Zozymus, Eriphia, Thalamita, Charybdis, Calappa, besides others of the Torrid zone, contain many large species, which are of very common occurrence; while the cold-water genera of Maioids appear to be much less prolific in species, and the other genera, though abounding in individuals, as Cancer and Lupa, are still but few in number. Any very exact comparison, however, of the two zones in this particular cannot be made without more data than have yet been collected. 
GEOGRAPHICAL DISTRIBUTION OF CRUSTACEA. 1505

TABLE II.

ANOMOURA, MACROURA, AND ANOMOBRANCHIATA.

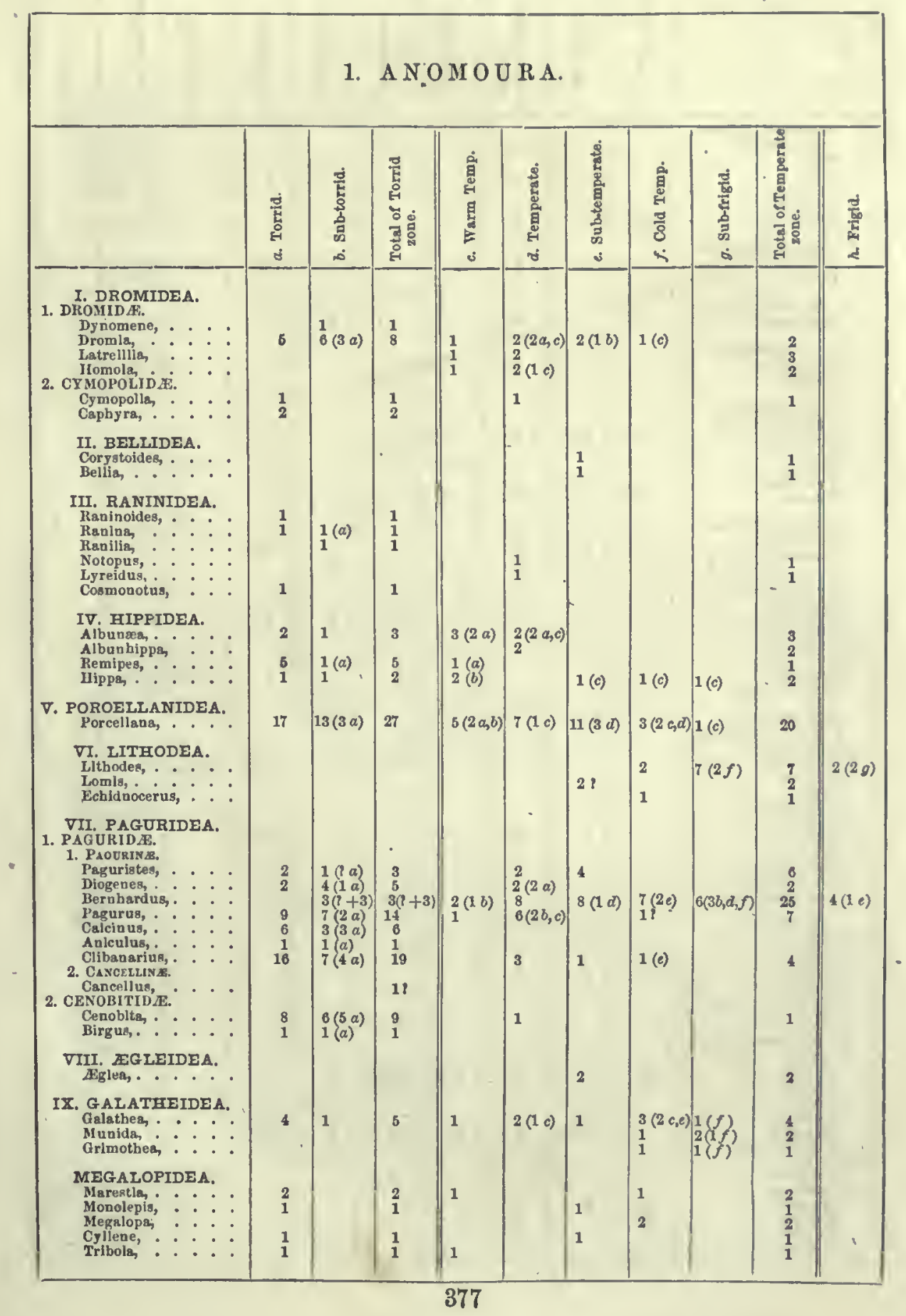


2. MACROURA.

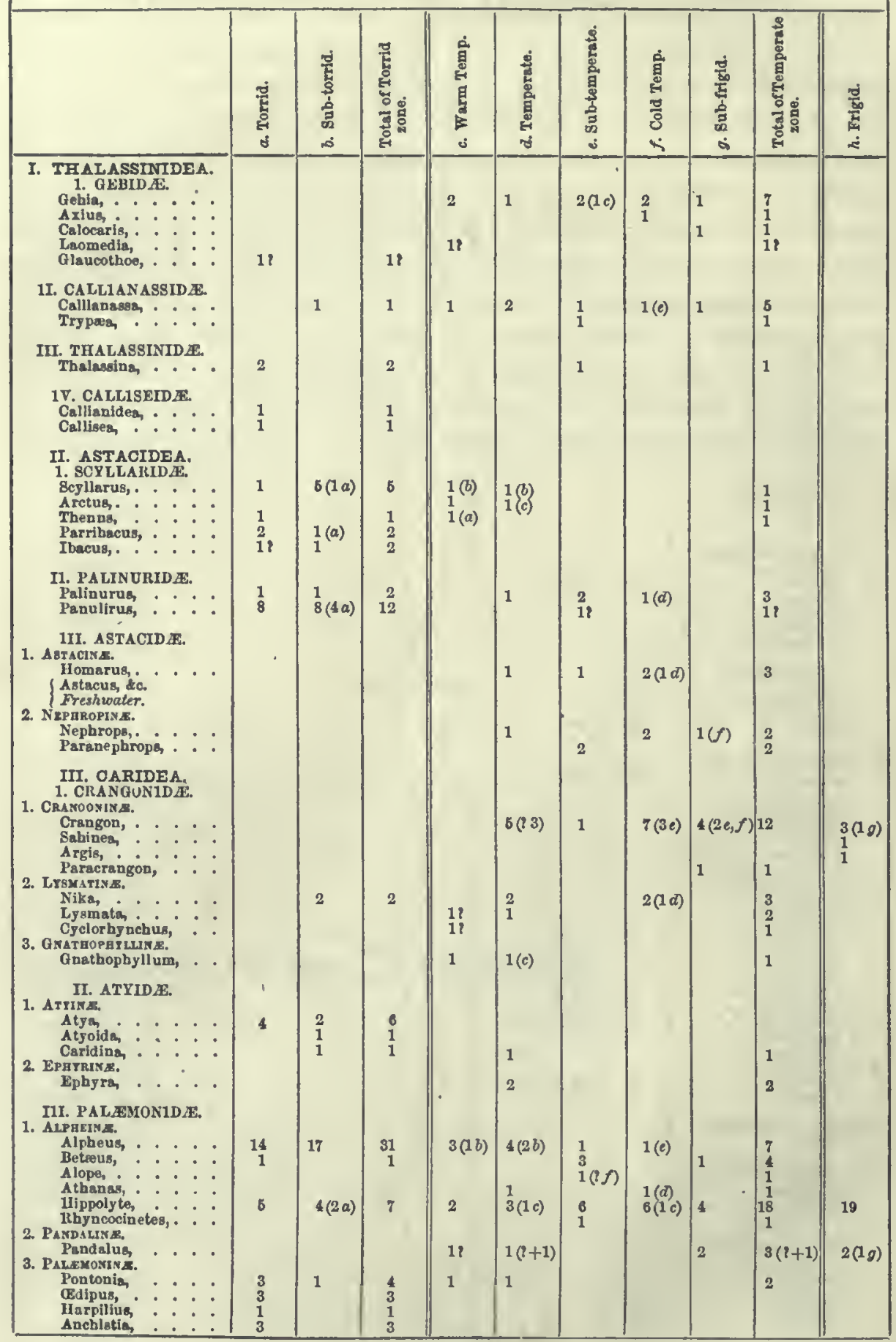


GEOGRAPHICAL DISTRIBUTION OF CRUSTACEA. 1507

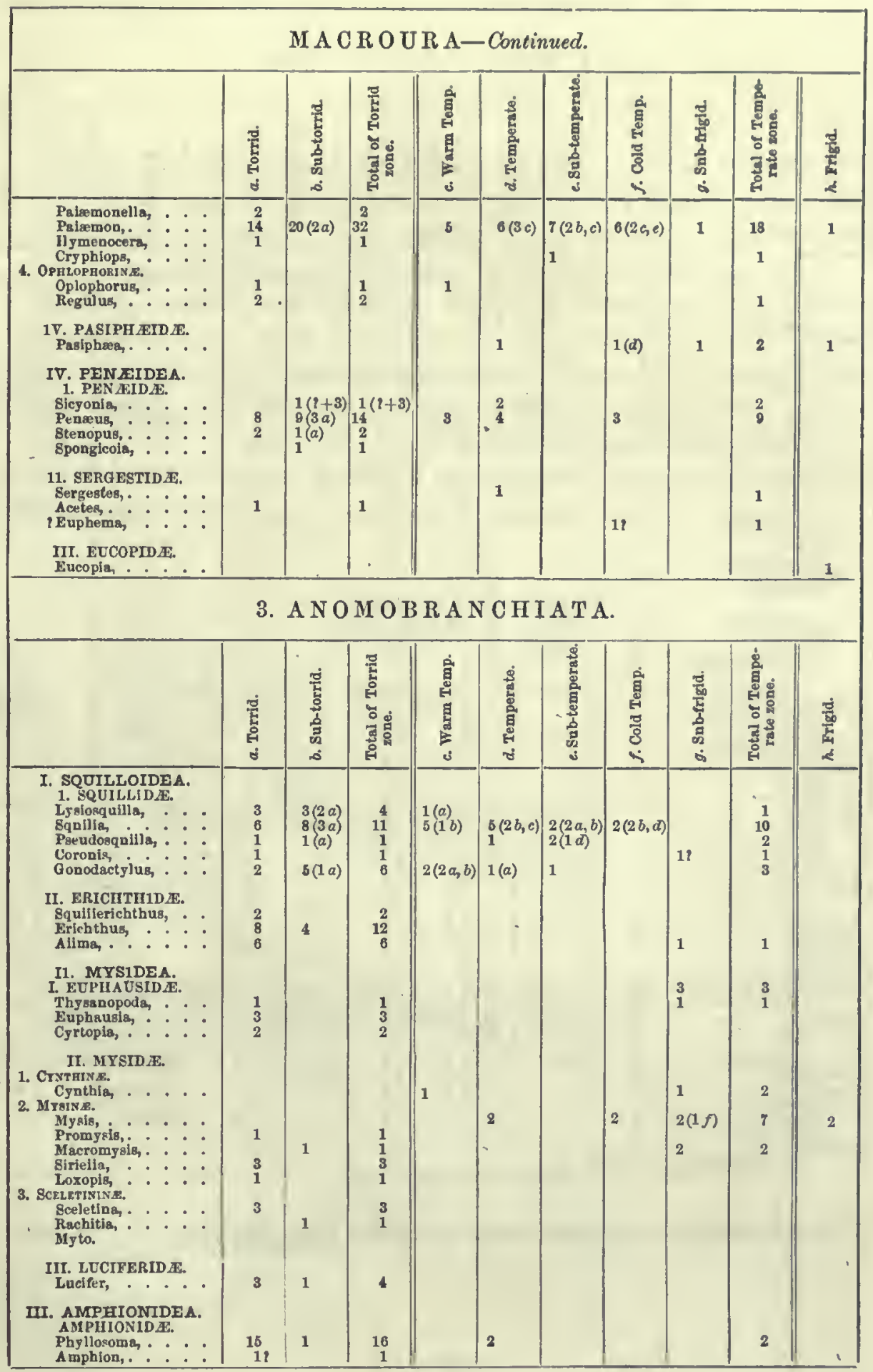


C R USTACEA.

4. RECAPITULATION.

\begin{tabular}{|c|c|c|c|c|c|c|c|c|c|c|}
\hline & 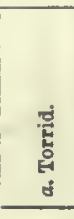 & 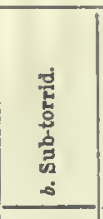 & 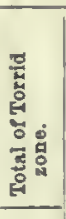 & : & 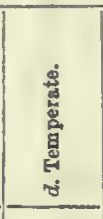 & 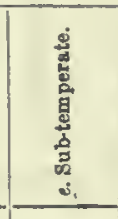 & 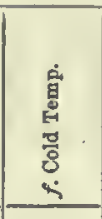 & 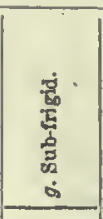 & 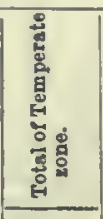 & 密 \\
\hline 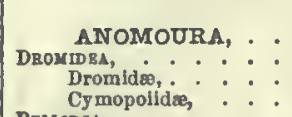 & $\begin{aligned} 90 \\
8 \\
5 \\
3\end{aligned}$ & $\begin{array}{c}59(25 a) \\
7(3 a) \\
7(3 a)\end{array}$ & $\begin{array}{c}125 \\
12 \\
9 \\
3\end{array}$ & & \begin{tabular}{|}
$43(11 a-0)$ \\
$73 a-0)$ \\
$6(3 a-0)$ \\
1
\end{tabular} & 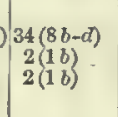 & \begin{tabular}{|l}
$25(8 c-c)$ \\
$1(c)$ \\
$1(c)$
\end{tabular} & $19(100-5)$ & $110 \mathrm{c}$ & \\
\hline 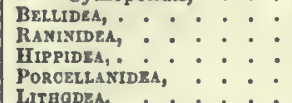 & $\begin{array}{c}3 \\
8 \\
17\end{array}$ & $\begin{array}{r}2(1 a) \\
3(1 a) \\
13(3 a)\end{array}$ & $\begin{array}{l}4 \\
10 \\
27\end{array}$ & $\begin{array}{l}8(4 a, b) \\
5(2 a, b)\end{array}$ & $\begin{array}{l}2 \\
4(2 a-c) \\
7(1 c)\end{array}$ & $\begin{array}{c}1(c) \\
11(B d) \\
1\end{array}$ & $\begin{array}{l}1(c) \\
3(2 c, \alpha) \\
3(1, j)\end{array}$ & $\begin{array}{l}1(c) \\
1(c) \\
7(2)\end{array}$ & \begin{tabular}{|c|c}
2 \\
2 \\
2 \\
80 \\
20
\end{tabular} & \\
\hline 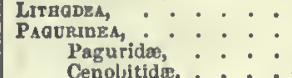 & $\begin{array}{r}45 \\
36 \\
9\end{array}$ & $\begin{aligned} 33(17) a \\
28(11 a) \\
7(6 a)\end{aligned} \mid$ & $\begin{array}{l}62 \\
52 \\
10\end{array}$ & $\begin{array}{l}3(1 b) \\
3(1 b)\end{array}$ & $\begin{array}{l}21(4 a-0) \\
21(4 a-a)\end{array}$ & $\begin{array}{l}1 \\
13(3 b, c, c) \\
13(s b, c, d)\end{array}$ & 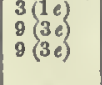 & 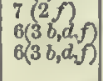 & $\left|\begin{array}{l}10 \\
44 \\
44\end{array}\right|$ & $\begin{array}{l}2(2 f, j, \\
4(1 e)\end{array}$ \\
\hline 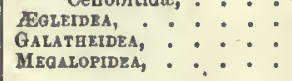 & $\begin{array}{l}4 \\
6\end{array}$ & 1 & $\begin{array}{l}5 \\
5\end{array}$ & $\begin{array}{l}1 \\
2\end{array}$ & $2(1 c)$ & & $\frac{5}{3}(2 c, e)$ & $4(3 f)$ & $\begin{array}{l}2 \\
7\end{array}$ & \\
\hline 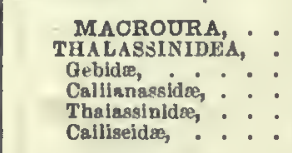 & $\begin{array}{c}84 \\
5 \\
1 ? \\
2 \\
2\end{array}$ & $\begin{array}{l}77(14 a) \\
1\end{array}$ & $\begin{array}{c}147 \\
6 \\
17 \\
1 \\
2 \\
2\end{array}$ & & $\begin{array}{l}40(88, c) \\
3 \\
\frac{1}{2} \\
\end{array}$ & $\begin{array}{l}35(4 b, c) \\
6(1 c) \\
2(1 c) \\
21 c \\
1\end{array}$ & $\begin{array}{l}36(12 d t e \\
4(1 e) \\
31(e)\end{array}$ & $\begin{array}{l}18(3 e, f) \\
3 \begin{array}{l}3 \\
2 \\
1\end{array}\end{array}$ & \begin{tabular}{|l}
$126(16)$ \\
17 \\
10 \\
6 \\
1
\end{tabular} & $29(2 g)$ \\
\hline $\begin{array}{l}\text { ASTACIDEA, } \\
\text { Scyllarida, } \\
\text { Palinurida, } \\
\text { Astaeidx (IIarine), }\end{array}$ & $\begin{array}{r}14 \\
5 \\
8\end{array}$ & $\begin{array}{r}16(6 a) \\
7(2 a) \\
9(4 a)\end{array}$ & $\begin{array}{l}24 \\
10 \\
14\end{array}$ & $\begin{array}{c}3(2 a, b) \\
3(2 a, b)\end{array}$ & $\begin{array}{l}4(2 b, c) \\
2(2 b, c) \\
\frac{1}{1}\end{array}$ & $\mid \begin{array}{l}0 \\
3 \\
3\end{array}$ & $\begin{array}{l}5(2 d) \\
1(d) \\
4(1 d)\end{array}$ & $\begin{array}{l}1(f) \\
1(f)\end{array}$ & $\begin{array}{r}14 \\
3 \\
\frac{4}{7}\end{array}$ & \\
\hline 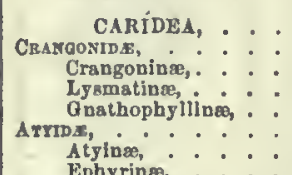 & 54 & $\begin{array}{l}48(4 a) \\
2 \\
2 \\
4 \\
4\end{array}$ & $\begin{array}{r}98 \\
2 \\
2 \\
8 \\
8\end{array}$ & $\begin{array}{l}13(?+3) \\
3(?+3) \\
22 \\
1\end{array}$ & \begin{tabular}{|l}
$28(5 b, c)$ \\
$8(8)$ \\
$5(: 3)$ \\
3
\end{tabular} & \begin{tabular}{|l}
$24(3 b, c)$ \\
$4(1 c)$ \\
1 \\
$2(c)$ \\
$1(c)$
\end{tabular} & $\begin{array}{l}24(10 c, e) \\
8(4 e) \\
7(3 e) \\
2(10)\end{array}$ & $\begin{array}{l}14(2 e f) \\
15 \\
6(2 e) \\
6(2 e f)\end{array}$ & $\begin{array}{l}81 \\
21 \\
14 \\
6\end{array}$ & $\begin{array}{l}28(29) \\
6(1) \\
b(19)\end{array}$ \\
\hline 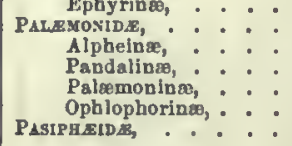 & $\begin{array}{l}51 \\
20 \\
27 \\
3\end{array}$ & $\begin{array}{l}\frac{42(4 a)}{21(2 a)} \\
21(2 a)\end{array}$ & $\begin{array}{r}89 \\
39 \\
46 \\
3\end{array}$ & $\begin{array}{l}13(1 b) \\
5(1 b b) \\
18 \\
1\end{array}$ & $\begin{array}{l}2 \\
16(5 b, c) \\
8(2 b, c) \\
1(++1) \\
7(3 c) \\
1\end{array}$ & $\begin{array}{l}20(2 b, c \\
12\end{array}$ & $\begin{array}{l}14(4 c, e) \\
8(3 c e) \\
6(2 c, e) \\
1(d)\end{array}$ & & $\begin{array}{l}2 \\
68 \\
33 \\
3(1) \\
21 \\
\frac{1}{2}\end{array}$ & $\begin{array}{l}22(1 g) \\
19 \\
2(1 g) \\
1 \\
1\end{array}$ \\
\hline 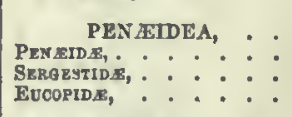 & $\begin{array}{c}11 \\
10 \\
1\end{array}$ & $\begin{array}{l}12(4 a) \\
12(4 a)\end{array}$ & $\begin{array}{r}19 \\
18 \\
1\end{array}$ & $\begin{array}{l}3 \\
3\end{array}$ & 5 & & $\begin{array}{l}3(?+1) \\
17\end{array}$ & & $\begin{array}{l}11 \\
2(1)\end{array}$ & \\
\hline 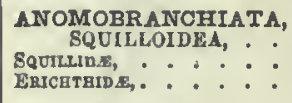 & $\begin{array}{l}62 \\
30 \\
13 \\
17\end{array}$ & 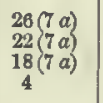 & $\begin{array}{l}82 \\
45 \\
21\end{array}$ & 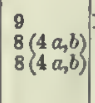 & 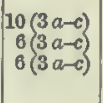 & $\begin{array}{l}5(2 b, d) \\
4(2 b, d) \\
5(3 b, d)\end{array}$ & $\begin{array}{l}4(2 b, d) \\
2(2 b, d) \\
2(2 b, d)\end{array}$ & $\begin{array}{l}10(1 f) \\
1(f+1) \\
11 \\
1 ?\end{array}$ & $\begin{array}{l}33(9, a b) \\
16(9) \\
16(9) \\
1\end{array}$ & 2 \\
\hline 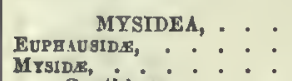 & $\begin{array}{r}17 \\
6 \\
8\end{array}$ & $\begin{array}{l}3 \\
2\end{array}$ & $\begin{array}{r}20 \\
6 \\
10\end{array}$ & $\begin{array}{l}1 \\
1\end{array}$ & & 1 & & $\begin{array}{l}8(1 f) \\
45(1 f)\end{array}$ & & 2 \\
\hline 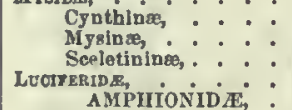 & $\begin{array}{c}5 \\
5 \\
3 \\
3 \\
15 \\
15-1\end{array}$ & $\begin{array}{l}1 \\
1 \\
1\end{array}$ & $\begin{array}{c}6 \\
4 \\
4 \\
17\end{array}$ & & 2 & & 2 & $4(1 f)$ & $\frac{2}{2}$ & 2 \\
\hline
\end{tabular}

The following deductions may be drawn from the preceding tables: 


\section{ANOMOURA.}

XVI. The Anomoura are nearly equally divided between the torrid and temperate zones, there being hardly one-tenth more torrid than cold-water species. Only fifteen species out of two hundred and twenty-five are common to the torrid and temperate zones.

Yet it is seen from the table, that if we except the Galatheidea, Lithodea, and part of the Paguridea, the species hardly extend beyond the warmer half of the temperate zone. There are but six known frigid species, and these are of the two last-mentioned groups.

XVII. The torrid zone and temperate zone sections of the Anomoura, are as follows; the frigid zone species being here added to the temperate.

1. TEMPERATE ZONE SECTION.

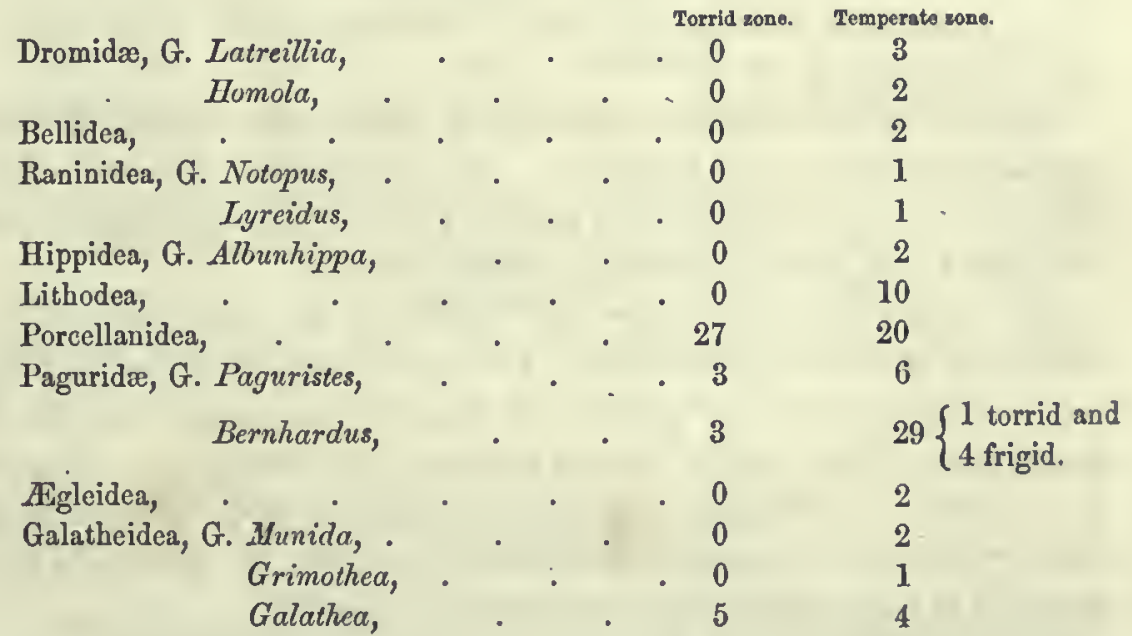

2. TORRID ZONE SECTION.

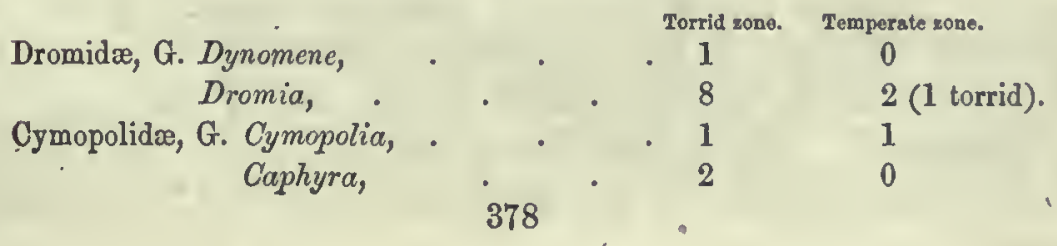




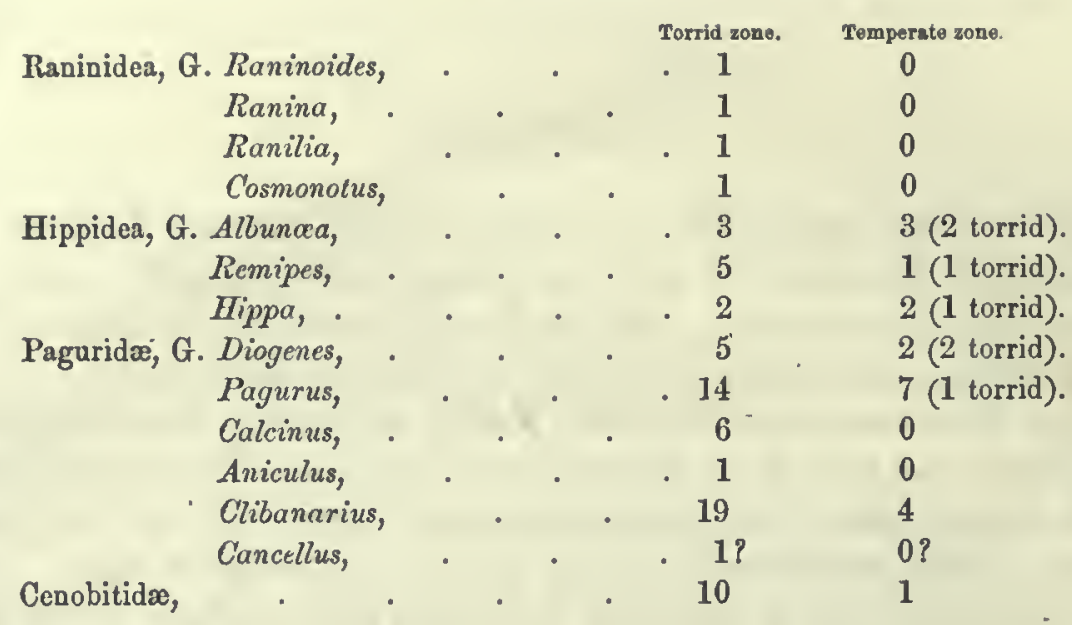

The Dromidea and Paguridea have one-third to one-fourth more torrid than cold-water species.

The Raninidea and Hippidea are mainly tropical. The two extratropical species of Raninidea occur only in the warmer of the temperate regions, and the species of Hippidea in the temperate zone (eight out of the whole number eighteen) have among them four that occur also in the tropics.

The Lithoden belong to the coldest temperate regions, abounding especially in the subfrigid region. The Galatheidea are mainly of the temperate zone; there are five known torrid species, and seven temperate, the latter pertaining to the colder seas.

The genus Porcellana has but two-thirds as many species in the temperate as in the torrid zone. Yet the subtemperate region contains but one less than the subtorrid, and some of the largest species of the genus occur here; while, on the contrary, the torrid zone species are quite small. Although, therefore, Porcellana may rank as a torrid zone genus, if we consider the relative number of species in the two zones, it is more properly a temperate zone genus.

The Paguridea range through both the tropics and temperate zone, even passing into the frigid zone. Bernhardus is mainly a cold-water genus, while Pagurus, Calcinus, and Clibanarius are mostly torrid genera. Pugurus has seven out of twenty-one species in the tempcrate zone. But it is in the torrid zone where the species of the largest size occur; the extra-torrid species belong almost exclusively to the Mediterranean. The species are exceedingly prolific in the tropics, far exceeding what occurs as regards any Paguridea in the temperate zone. 
XVIII. It was found in the Brachyura, that the highest species among the Maioids, and the highest of Crustacea occur in the extratropical regions; and that as we descend to the Cancroids, the species become mainly tropical; moreover, as we descend among the Cancroids (the type of which is tropical), there is in general a return to the less genial colder waters, as exemplified in the true Cancers or Cancridx and the Corystoidea, these last being mainly cold-water species. By these steps we find the more degraded forms among the Brachyura occurring in both the colder and warmer waters. We cannot therefore expect that the Anomoura, which are properly Brachyura of a still lower grade, should be arranged according to rank in one zone in preference to the other. And it is a fact that the genera of higher species occur about equally in the two zones. Latreillia, but a single step below the Inachidx, is found in the warmer temperate regions; and Dromia, a little lower, has three-fourths of its species in the tropics. Homola, again, has been found only in the temperate zone.

Among the Paguriden; the Bernhardi or cold-water species are probably the superior in rank; and the Lithoden, which are a grade higher still, are from the neighbourhood of the frigid zone.

The Hippidea, which have been considered as in the Corystoid series (page 54), but below the Corystoidea, are mostly from warmer waters.

The most bulky forms among the Anomoura are found in the genera Lithodes, Ranina, and Dromia. The common Ranina dentata has a length of five inches in the Japan Seas, while in the warm East Indies (at the Moluccas), as De Haan states, four inches is the greatest length.

\section{MACROURA.}

XIX. The Macroura, according to the table, are nearly equally divided between the torrid and extra-torrid zones, the former including one hundred and forty-seven species, and the latter one hundred and fifty-three species.

In the above table we have not included the fresh-water Astacidæ, as we are treating only of marine species. Yet in a comparison of numbers between the zones, these should be brought in. They are about thirty-six in number, and all, excepting perhaps one, belong to 
the temperate zone. With this addition, the numbers become one hundred and forty-seven for the torrid zone, and one hundred and eighty-nine for the extra-torrid. Sixteen of the cold-water species are common to both the torrid and temperate zones, and twenty-nine occur in the frigid zone, twenty-seven being peculiar to this zone. This is strikingly in contrast with the Brachyura, of which two-thirds are torrid species, and only five or six are known to extend into the cold zone, of which but one is confined to it.

XX. The Thalassinidea are mainly extra-torrid species.

The Astacidea are divided between the warm and cold seas; the Palinuridæ and Scyllaridæ being mostly of the former, and the Astacidæ almost exclusively of the latter.

The Caridea spread largely over both zones; but extensive groups are extra-torrid, and some genera contain many frigid species.

The Penæidea are mainly of the torrid zone.

The exact ratios will be gathered from the preceding tables.

XXI. The geographical relations of the subordinate groups are shown in the following table.

1. TEMPERATE AND FRIGID ZONE SECTION.

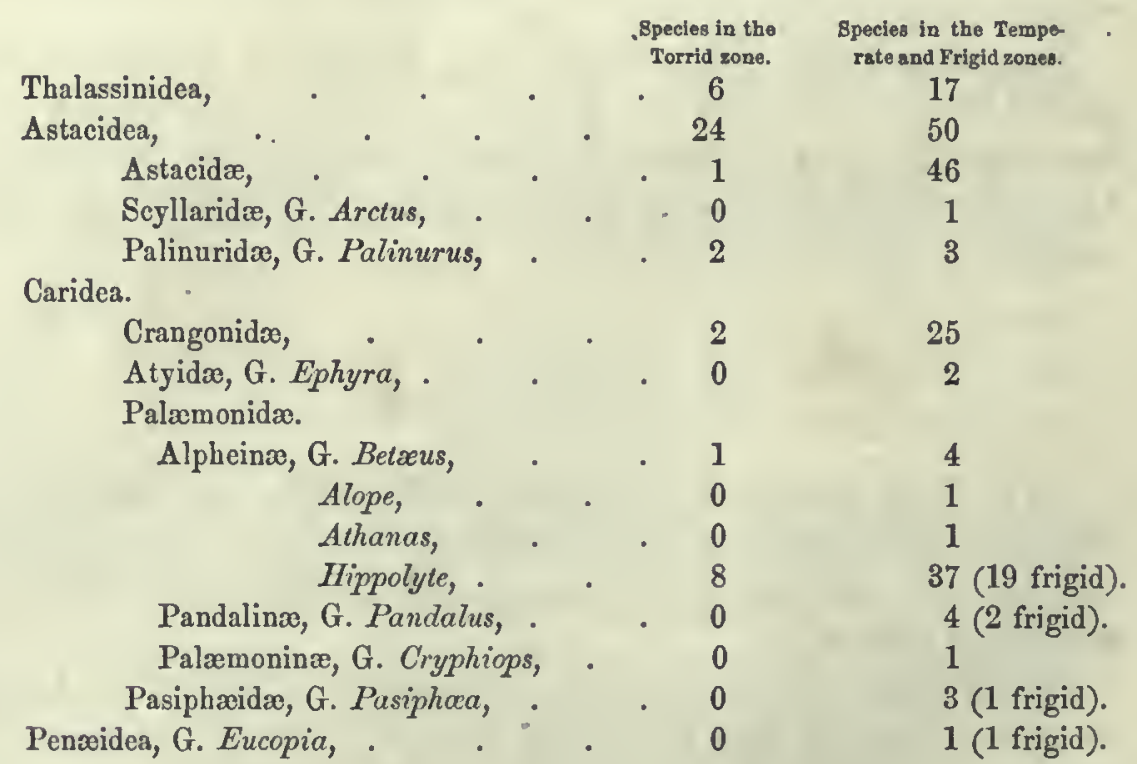


2. TORRID ZONE BECTION.

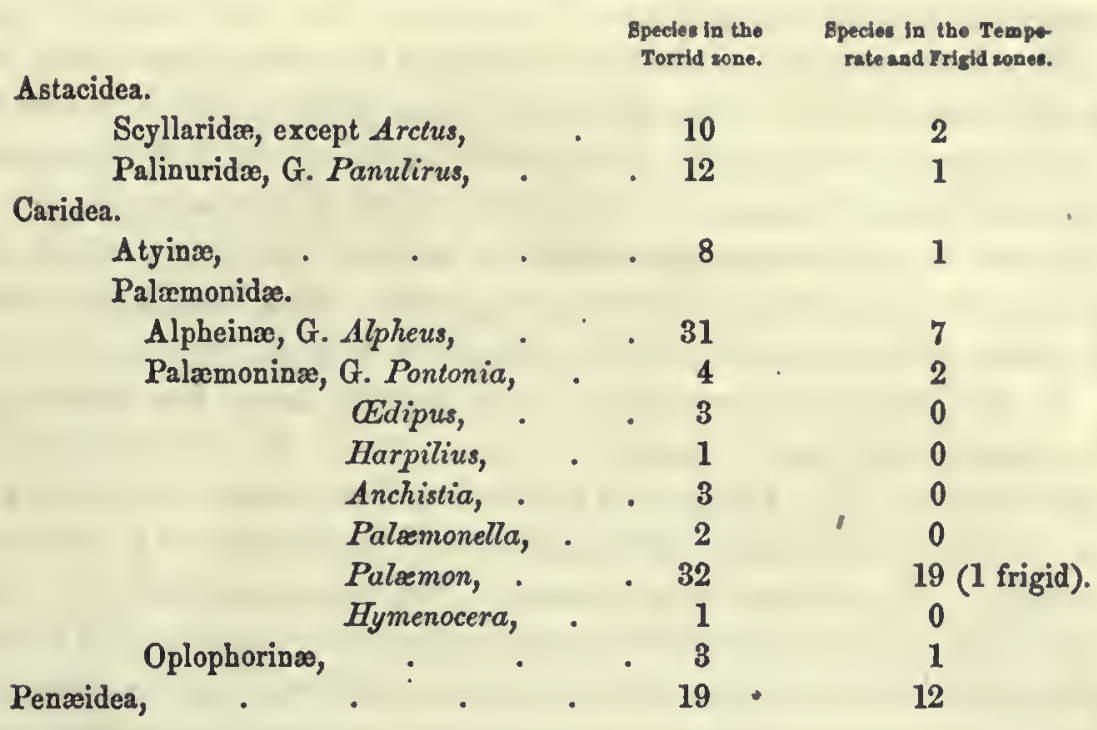

XXII. Considering the Scyllaridæ and Palinuridæ as the Macroura highest in grade, this division of the Podophthalmia appears at first to have its superior developments in the tropics. But it may still be questioned whether this is altogether true. The Palinuridx include two genern, one Palinurus, mainly a cold-water genus, the other Panulirus, a warm-water or Torrid zone genus: and is the Torrid zone genus the superior in rank, as should be the case, if the tropics are the most congenial to the highest Macroural developments? Palinurus has the outer antenno nearly in contact at base, and the flagella of the inner antennæ are very short; Panulirus, the warmwater genus, has the outer antennix remote at base, and the flagella of the inner antennæe very long. The genera are thus characterized by marks analogous to those that distinguish the higher and lower species among the Brachyura, or that exhibit the superiority of the Brachyura as a class over the Macroura; and if such evidence is here to be regarded, the cold-water genus, Palinurus, is the higher in rank. Moreover, the aspect of the Palinuri, the harder shell and more compact body, strike the eye at once as indicating their higher character. In size, they are not at all inferior; they even exceed the Panuliri in bulk if not in length. Among the Palinuri, one species is afforded by the warm seas of the West Indies; but it is not half the size lineally, 
of the Lalandii of the Cape of Good Hope, or the vulgaris of the Mediterranean, both gigantic species, sometimes a foot and a half in length independent of the antennæ.

The Astacidæ, the remaining family in the tribe Astacoidea, is confined almost wholly to the colder waters, and the species are numerous.

Among the Caridea, the Crangonidæ certainly have the precedence. The fact that the first pair of legs have perfect hands, while the other legs are vergiform, shows a relation to the Brachyura, which is evidence of superiority. These Crangonidæ, thus the highest of the Caridea, are almost exclusively cold-water species.

In the family Palæmonidæ, some genera have the anterior legs furnished with stout hands, while in others the second is the stout chelate pair. The former, for the reason just alluded to while speaking of the Crangonidæ, and elsewhere farther explained, are superior in rank. It is among these genera of this superior grade, the Alpheinæ, that we find the cold-water and boreal species. The genus Hippolyte alone contains thirty-seven cold-water species, nineteen of which are of the Frigid zone; and there are only eight torrid species.

On the contrary, among the Palæmoninæ, the inferior group, there are forty-six torrid to twenty-two of extra-torrid; and only one of the latter is boreal. Species of Alpheus are common in the tropics about coral-reefs; but the largest species of the genus, two or three inches long, occur beyond the tropics.

The Penæidea, the lowest of the tribes of Macroura, are mainly tropical. Yet, the very lowest species (like the lowest Brachyura) occur partly in the colder waters, or even in the Frigid zone.

XXIII. Comparing the torrid and temperate species of Macroura, we are led to conclude, that the latter are probably most numerous in individuals, and the most bulky in mass. Excepting the Panuliri, Scyllari, and some Palæmons, the tropical species are small, and moreover, they are not particularly abundant about coral-reefs. The species of the torrid genera, Pontonia, Edipus, Harpilius, Anchistia, Palæmonella, Hymenocera, and Atya, are all quite small, the greater part not exceeding an inch and a quarter in length, and moreover, the tropical Alphei are also small species, as stated above. The Penæidea are partly larger species. Contrast these particulars with the facts as to the genera of the Temperate zone. Palinurus, Astacus, Nephrops, Paranephrops, Homarus, Arctus, Crangon, and the related genera, Hippolyte, Pandalus, Cryphiops, contain species mostly of 
large size, and the adult Homari and Palinuri are not exceeded in weight by any other Macroura.

The Thalassinidea, which belong almost exclusively to the temperate regions are smallest in the warmer part of the Temperate zone, and larger in the middle and colder part. A Puget Sound species (subfrigid region) of Callianassa (C. gigas) is at least four and a half inches long, the $C$. uncinata of Chili, five inches, and the Thalassina scorpionides of Chili, six inches. The facts respecting this subtribe, added to those mentioned above, strengthen much the conclusion, that the cold-water genera have the largest species; for all the species are over an inch and a half in length.

\section{ANOMOBRANCHIATA.}

XXIV. The Mysiden, to which the Penæidea are related, are, to a considerable extent, cold-water species, although many are found also in the tropics. There are among them twenty torrid species and seventeen extra-torrid species.

In the Squilloidea we have an example of an inferior grade in a large lax body, with a small head and long abdomen; and they remind us of overgrown larval forms, or species vegetatively enlarged beyond the normal or most efficient size. In this particular they have some analogies with the earlier forms of life. They are found mostly within the tropics. Twenty-four of the Squillidæ are Torrid zone species, and only seven pertain exclusively to the Temperate zone. Of the Erichthidx, twenty-one out of twenty-two species are reported from the Torrid zone. The Amphionidea, a related group, include seventeen Torrid zone species and two of the Temperate zone. 
C R USTACEA.

TABLE III.

TET RADECAPODA.

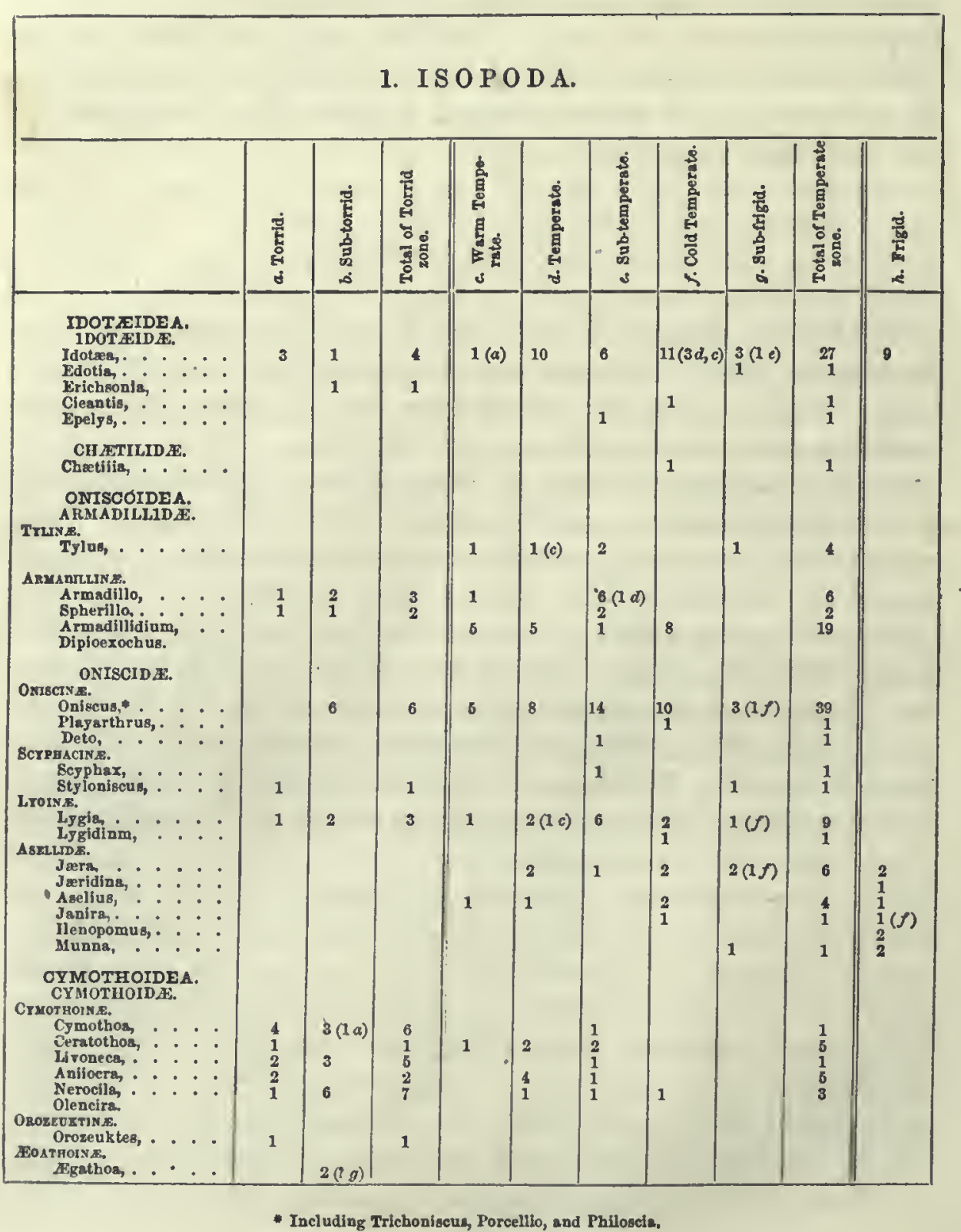


GEOGRAPHICAL DISTRIBUTION OF CRUSTACEA. 1517

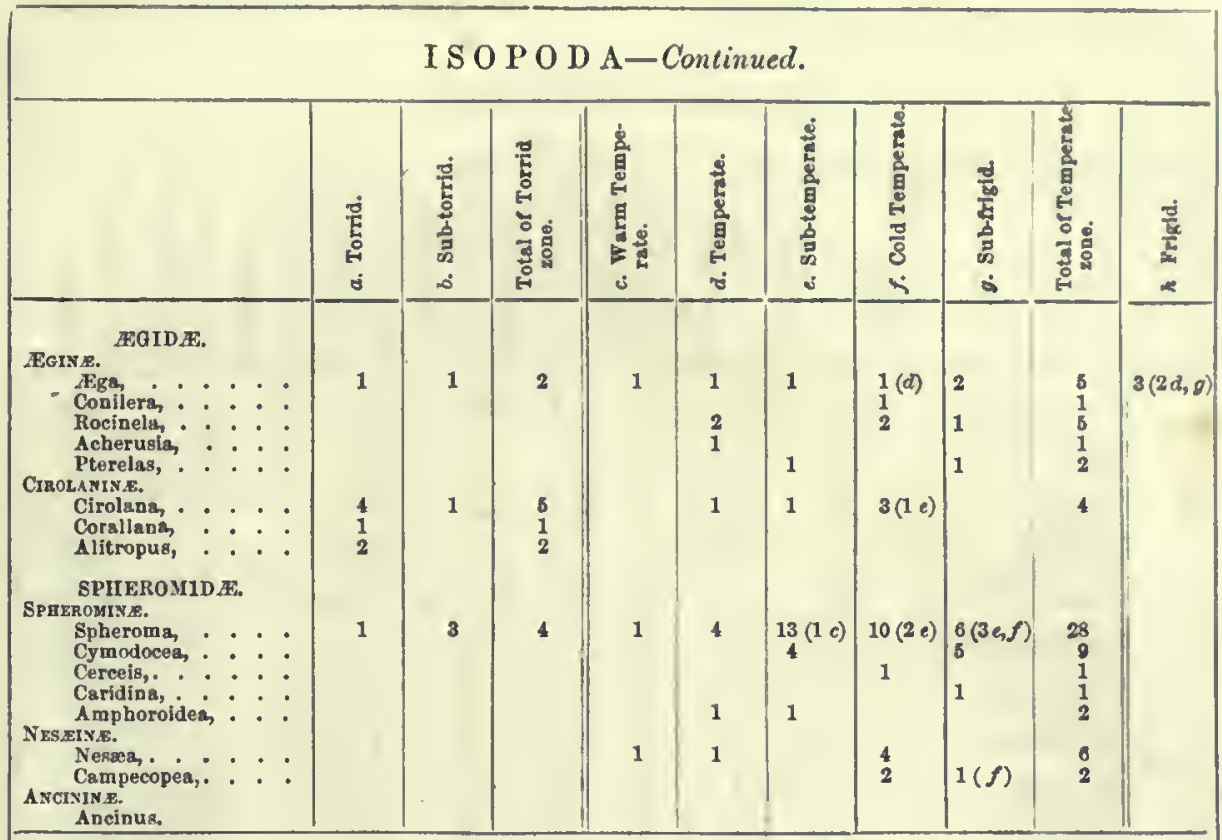

2. A N I SOPODA.

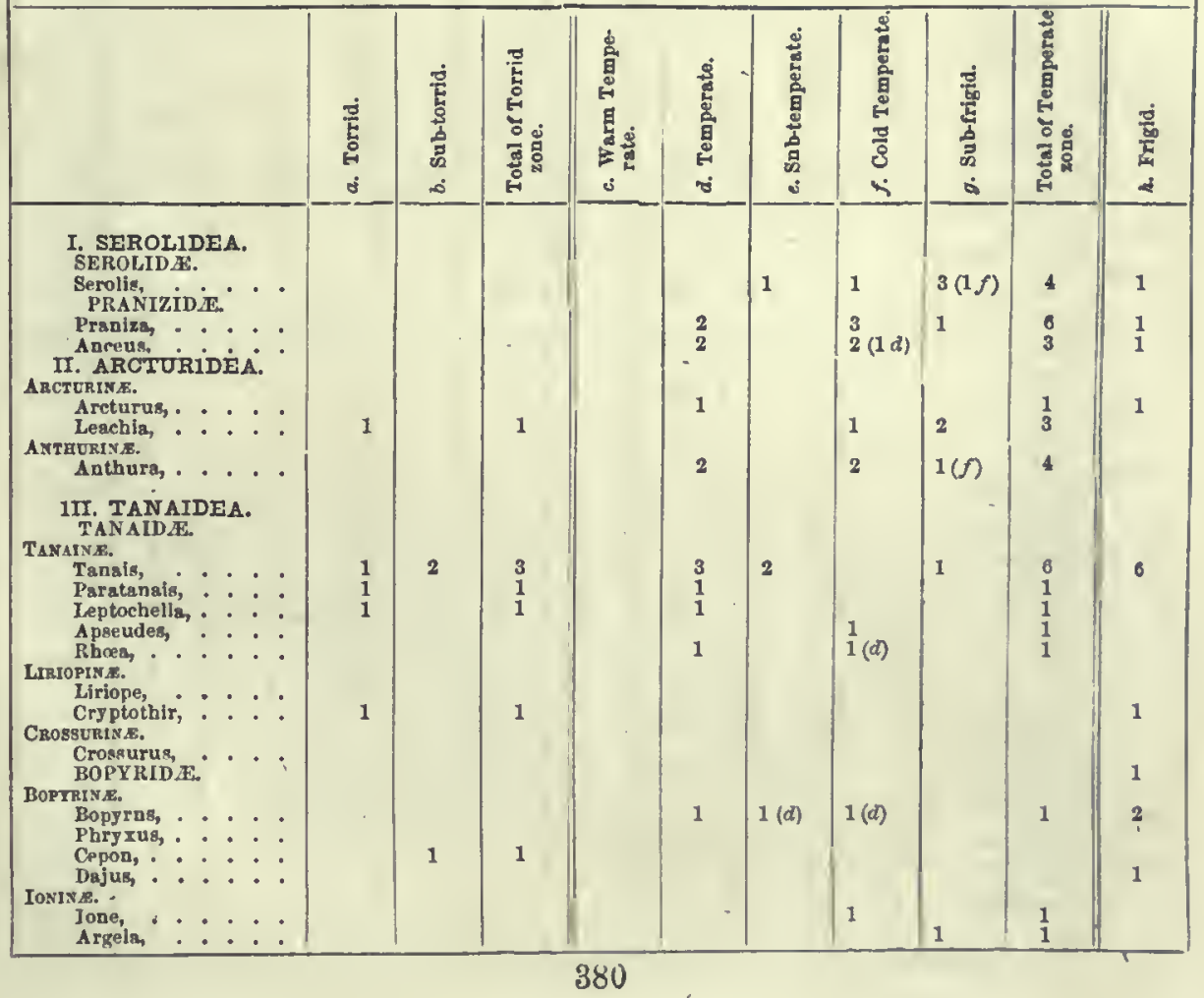


C R UST A C EA.

3. $\triangle$ M PH I PODA.

\begin{tabular}{|c|c|c|c|c|c|c|c|c|c|c|}
\hline & 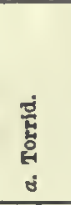 & 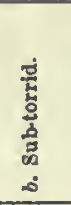 & 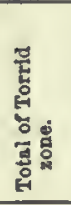 & 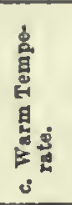 & 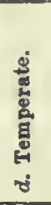 & 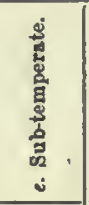 & 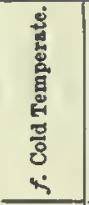 & 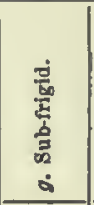 & 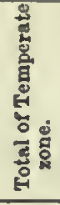 & 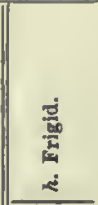 \\
\hline 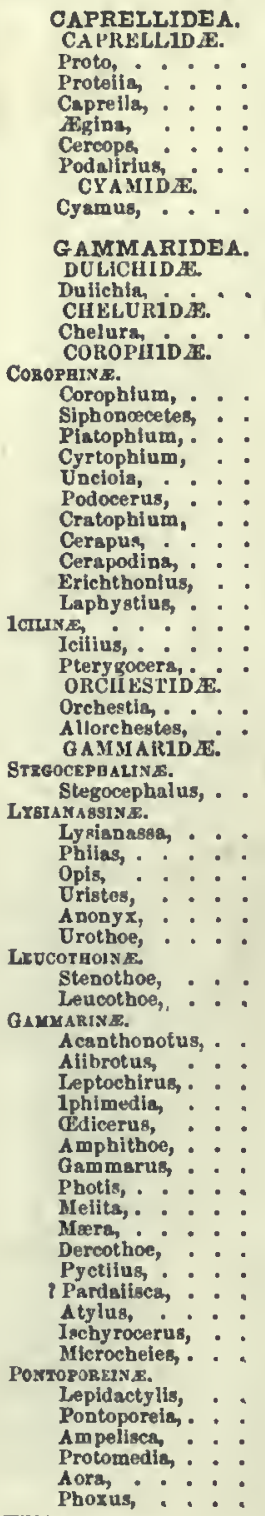 & (b) 2 & (1) 1 & $\begin{array}{l}2 \\
. \\
2 \\
1 \\
1\end{array}$ & $\begin{array}{l}1 \\
2\end{array}$ & $\frac{4}{2}$ & $\begin{array}{l}3 \\
1 \\
2 \\
3 \\
1\end{array}$ & $\begin{array}{l}1 \text { (?) } \\
1 \\
1 \\
1 \\
1 \\
2 \\
1 \\
2 \\
12(1 d) \\
1 \\
4\end{array}$ & $\begin{array}{l} \\
3 \\
2\left(1 f^{f}\right) \\
1\end{array}$ & $\begin{array}{r}1 \\
1 \\
2 \\
1 \\
8 \\
1 \\
12 \\
23\end{array}$ & \begin{tabular}{|l}
2 \\
3 \\
14 \\
1 \\
$14(2 f)$ \\
$\frac{1}{2}$
\end{tabular} \\
\hline
\end{tabular}


GEOGRAPHICAL DISTRIBUTION OF CRUSTACEA. 1519

\begin{tabular}{|c|c|c|c|c|c|c|c|c|c|c|}
\hline \multicolumn{11}{|c|}{ A M P H I P O D A-Continued. } \\
\hline 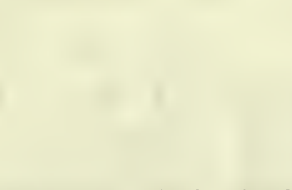 & 惫 & 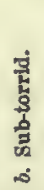 & 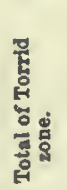 & 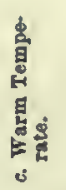 & 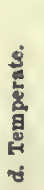 & 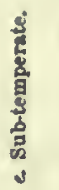 & 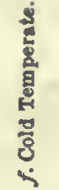 & $\begin{array}{l}\text { 离 } \\
\text { 离 } \\
\text { 㤩 } \\
\text { a }\end{array}$ & 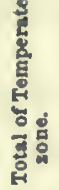 & 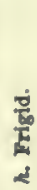 \\
\hline 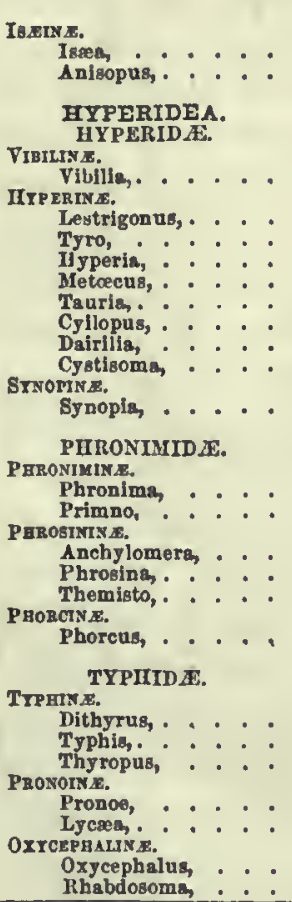 & $\begin{array}{l}1 \\
1\end{array}$ & 18 & $\begin{array}{l}4 \\
2 \\
1 \\
4 \\
2\end{array}$ & $\begin{array}{l}1 \\
2\end{array}$ & 1. & 18 & $2 t$ & 1 & $\begin{array}{l}1 \\
1 \\
6 \\
1 \\
11\end{array}$ & $\begin{array}{l}1 \\
1 \\
1\end{array}$ \\
\hline
\end{tabular}




\section{RECAPITULATION.}

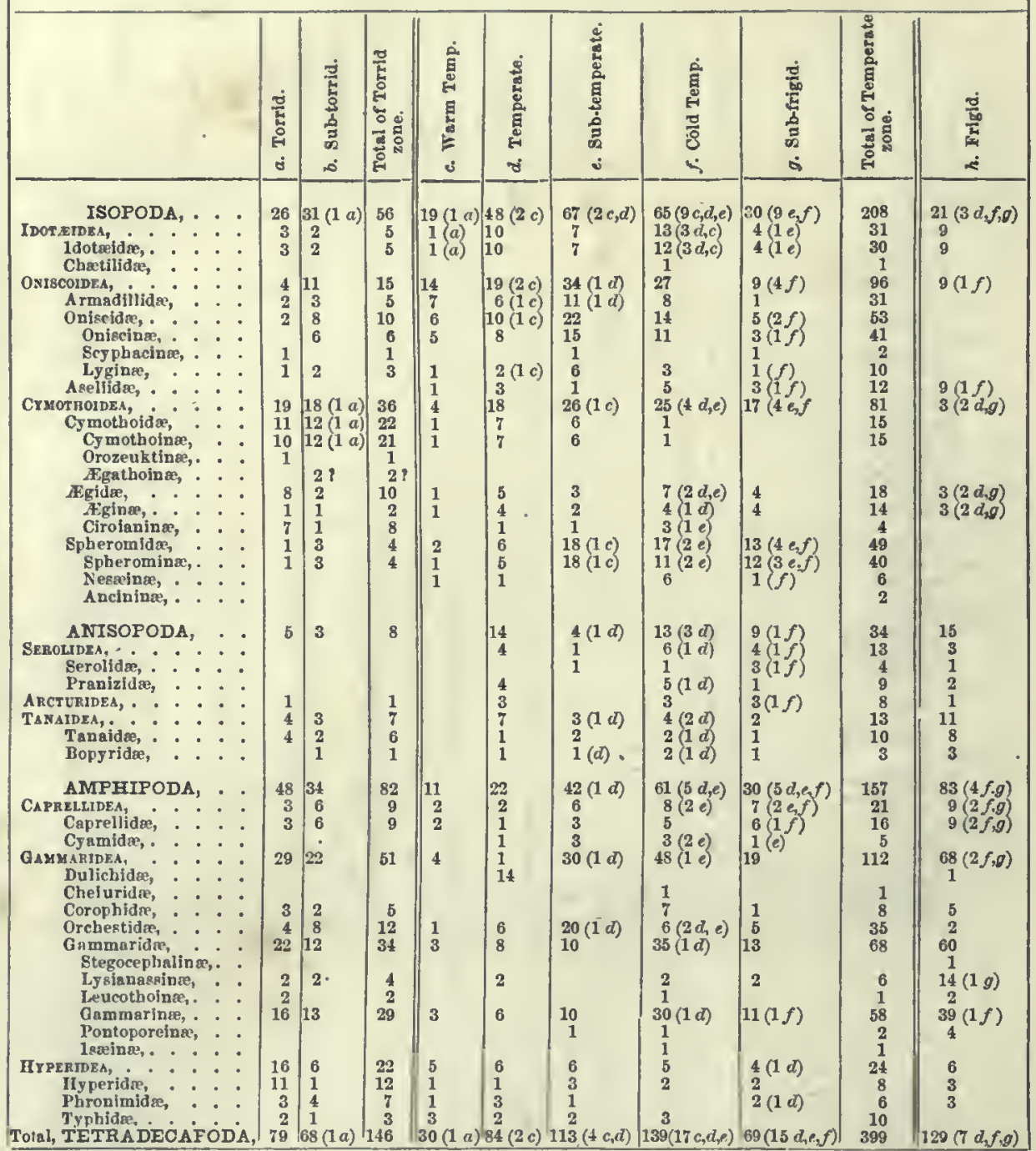

Before stating the conclusions from the above tables of the Tetradecapoda, it should be observed that this division of Crustacea has been less thoroughly explored than that of the Podophthalmia, and future investigations must vary much the proportions between the species of the different regions. The coasts of Europe and the northern seas, are within the reach of European zoologists, and have been carefully examined; while voyagers through the tropics have 
GEOGRPHICAL DISTRIBUTION OF CRUSTACEA. 1521

usually contented themselves with collecting the larger Crustacea. In the genus Gammarus, not a tropical species had been reported, until our investigations, which brought ten or eleven to light, being one-third the whole number of those of ascertained localities reported to this genus.

Some general conclusions may, however, be safely drawn from the facts already known, although the exact ratios deduced from the tables may hereafter be much modified.

I. The Tetradecapoda are far more numerous in extra-tropical latitudes than in the tropical.

The proportion in the above table is $521: 146$; allowing for future discoveries, it may be set down at $2: 1$, without fear of exceeding the truth.

II. The genera of extra-tropical seas are far more numerous than those of the tropical.

Out of forty-nine genera of Isopoda, only nineteen are known to occur in the tropics, and but four of these are peculiar to the tropics.

Out of twenty genera of Anisopoda, six only are known to be tropical, and but two are exclusively so.

Among the Amplipoda, out of fifty genera of Gammaridea, only seventeen are known to contain tropical species; nine are exclusively tropical, and but ten, including these nine, have more tropical than extra-tropical species. The Caprellidea and Hyperidea embrace thirty genera, fifteen or sixteen of which include tropical species.

The variety of extra-tropical forms compared with the tropical, is hence very great.

III. From the tables, the ratio of extra-tropical and tropical species in the

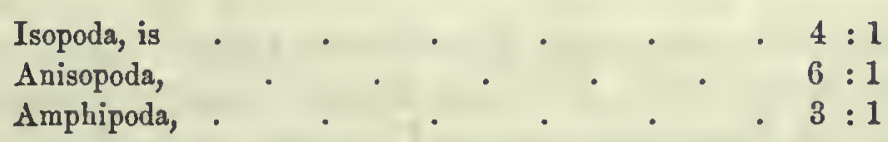

Among the Isopoda, the Idotæidea are the most decidedly cold-water species, and the Cymothoidea, the least so. The ratio of species for the

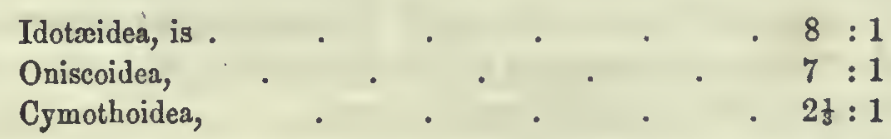

Two-ninths of the extra-tropical Idotæidea (or nine species) belong 
to the Frigid zone, and nearly one-tenth of the extra-tropical Oniscoidea (or nine species); while less than a twenty-fifth of the Cymothoidea occur in the Frigid zone, and but one of these has not also been found in lower latitudes.

Of the Amphipoda, the Gammaridea are most strongly extratropical, the proportion being for the extra-tropical and tropical species $3 \frac{1}{2}: 1$; while the ratio in the Caprellidea, is $3: 1$; and in the Hyperidea, $1 \frac{1}{1}: 1$. Out of one hundred and seventy-eight extra-tropical species of Gammaridea, sixty-six are Frigid zone species, besides two which have been found both in the Frigid and Temperate zones.

IV. The genera which extend into the frigid region are the following. The names of those more especially frigid, according to present knowledge, are italicized; and the proportion of frigid species to the whole number of extra-tropical, is mentioned in decimals, where they are not exclusively frigid.

IDот жIDEA.-Idotra (0.3), Glyptonotus.

Oniscoidea.-Jæra (0.25) Jaridina, Asellus (0.20), Janira (0.5), Henopomus, Munna $(0 \cdot 66)$.

CтмотноіDeA.- Ega $(0.4)$.

Serolidea.-Serolis (0.2), Praniza (0.15), Anceus (0.25).

Arcturidea.-Arcturus (0.5).

Tanaldea.-Tanais (0.5), Liriope, Crossurus, Phryxus, Dajus.

Capreluidea. - Proto (0.5), Caprella (0.24), Agina, Cercops, Podalirius.

Gammaridea.-Dutichia, Siphonocetes, Unciola (0.5), Podocerus (0.5), Laphystius, Orchestia (0.07), Stegocephalus, Opis (0.66), Uristes, Anonyx $(0 \cdot 9)$, Leucothoe $(0 \cdot 66)$, Acanthonotus (0.75), Iphimedia (0.6) Edicerus (0.5), Gammarus (0.33), Melita (0.5), Pardalisca, Ischyrocerus, Michrocheles, Pontoporeia, Ampelisca, Protomedeia, Phoxus.

HyperideA.-Hyperia $(0 \cdot 14)$, Mletocus, Tauria, Themisto (3.0).

The Spheromidæ are nearly all cold-water species, though not reaching into the Frigid zone. There are forty-nine known species of Spheromida in the Temperate zone, and but four in the Torrid. Serolis is a peculiar cold-water form, belonging mainly to the subfrigid and frigid regions. Orchestia is to a large extent of the Temperate zone, while Allorchestes is more equally distributed through the torrid and temperate. Amphithoe, as restricted by us, is alike common in the torrid and temperate regions; while Iphimedia, the other section of the old group, is mainly a cold-water genus.

The Hyperidea are mostly tropical genera.

V. The species and genera of Tetradecapoda are not only most 
abundant in the extra-tropical regions, but besides, the individuals of specics appear to be more numerous, or at least not less so. At Fuegia, the quantity of Gammarida collected on bait dropped in the water was exccedingly large; and in no region visited by us, did we find evidence of as great profusion. The Spheromæ were also very abundant along the shores.

VI. Morcover, the species of extra-tropical waters are the largest of the tribe. In the Frigid zone, there are Idotæidæe three to four inches long, while the average sizc of the tropical species is less than threefourths of an inch; there are Spheroma an inch long, while those of the tropics seldom exceed a fourth of an inch; there is a Lysianassa thrce inches long, while the warmer seas afford only small species, half an inch in length; there is a Pterelas over an inch in length, while the Egidæ of the tropics are less than half an inch. The Gammari of the tropics are small slender species, not half the size of those of the colder seas. The species of Serolis are an inch to two inches long. Thus, through the Idotæidea, the Agidæ, Serolidx, Spheromidx, Caprellidea, and Gammaridea, the largest spccies belong to the colder seas, and the giants among Tetradecapods, are actually found in the Frigid zone.

Among the Hyperidea there is one gigantic species, belonging to the genus Cystisoma, which is over three inches long. It is reported from the Indian Ocean, but whether tropical or not is unascertained. Of the species of this group examined by the writer, the largest, a Tauria, was from the Frigid zone.

VII. Again, the Tetradecapoda of extra-tropical waters are the highest in rank. Among the Isopoda (which stand first), the Idotaidea appear to be of superior grade, and these, as observed, are cspecially developed in the colder seas, reaching their maximum size in the Frigid zone. Again the Serolidx, the highest of the Anisopoda, are cold-water spccies. The Orchestix among the Amphipoda, although reaching through both the Torrid and Temperate zoncs, are largest and much the most numerous in the latter.

VIII. Those species of a genus that occur in the colder waters, are often more firmly put together, and bear marks of supcriority in their habits. The Amphithoe and Gammari of the tropics are lax and slender specics, of small size compared with those of the colder seas.

IX. There is a tendency in the colder waters to the development of spinous species. This fact is as true of the Podophthalmia as of the 
Tetradecapoda. Among the former, there are the thorny Lithodes, the numerous Maioids armed with spines, the Acanthodes; while the Cancroids and Grapsoids of the tropics are usually very smooth and often polished species. There are the spinous boreal Crangons, the species of which genus in the warmer seas are without spines. Among the Tetradecapods, the boreal Iphimedia are often spinous or crested; Acanthonotus and Dulichia are spinous genera. The same tendency is seen in the third pair of caudal stylets in some cold-water Gammari, which have the branches spinulous instead of furnished with a few minute hairs like those of the tropics.

There are also some spinous Crustacea in the tropics, as the Palinuridro and species of Stenopus. Such facts, however, do not lead to any modification of the previous remark; for the tendency observed is still a fact as regards the several genera mentioned.

\section{ENTOMOSTRACA.}

The Entomostraca have been little studied out of the Temperate zone, if we except the results of the author's labours. The described species of most of the families are, therefore, almost exclusively from the temperate regions, and we know little of the corresponding species or groups in the warmer seas. The following table presents the number of known species of the torrid and extra-torrid zones, omitting the Lernæoids:-

\section{TABLE IV.}

\begin{tabular}{|c|c|c|c|c|c|}
\hline \multicolumn{6}{|l|}{ LOPHXROPODA. } \\
\hline Cyclopoidea, & \multicolumn{3}{|c|}{ LOPHXROPODA. } & 120 & 76 \\
\hline Daphnioidea, & . & . & . & 5 & 46 \\
\hline Cyproidea, & . & . & . & 13 & 61 \\
\hline \multicolumn{6}{|l|}{ Phyliopoda. } \\
\hline Artemioidea, & . & & . & 0 & 10 \\
\hline Apodoidea, & . & . & . & 0 & 3 \\
\hline Limnadioidea, & . & 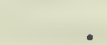 & . & 2 & 2 \\
\hline \multicolumn{6}{|l|}{ P๕cilopoda. } \\
\hline Ergasiloidea, & . & & . & 1 & 4 \\
\hline Caligoidea, . & . & . & & 16 & 33 \\
\hline
\end{tabular}

Were we to leave out of view the researches of the author, the number of species and the proportion for the Cyclopoidea, instead of 120 to 76 , would be about $3: 50$, thus not only reversing the ratio, 
but giving to the Temperate zone almost all the species of the group.* Moreover, no Daphnioids and few Caligoids have been yet reported from the Torrid zone, excepting those described in this Report. The author's time when on land in the tropics was devoted mainly to the department of Geology, and consequently the fresh-water Entomostracans were not as thoroughly collected as those of the oceans. He therefore attempts to draw no conclusions from the above ratios.

A few facts may, however, be deduced with respect to some genera, and especially those of the Cyclopoidea. The following table gives the number, as nearly as known, of the species of each genus of the Cyclopoidea, occurring in the torrid and extra-torrid zones. The number common to the extra-torrid and torrid zones is mentioned in brackets.

TABLE V.

\section{CYCLOPOIDEA.}

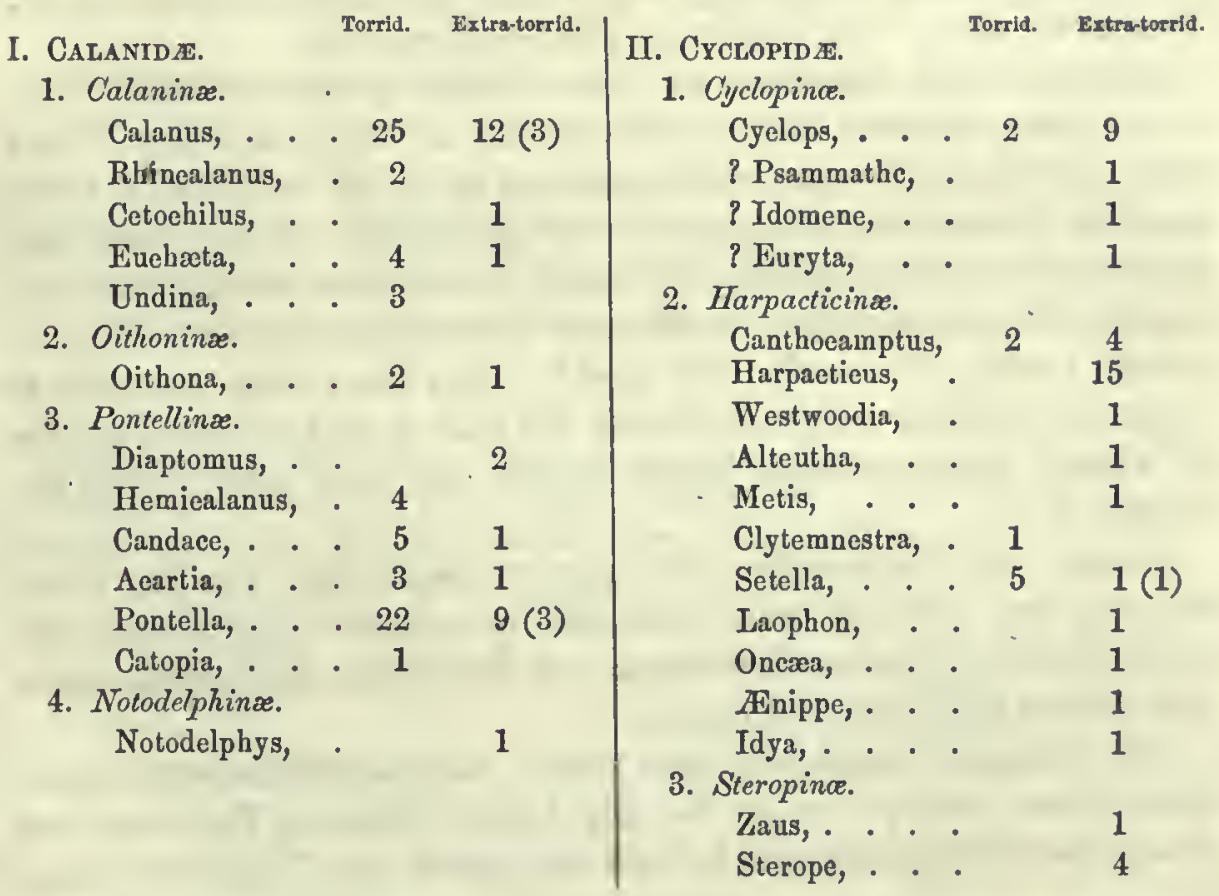

* The whole number of Cyelopoidea deseribed previous to May, 1842, by which time the author's observations were eompleted, was less than twenty-five; and of the oceanic Cyelopoids, one hundred and fifty speeies of which the author has deseribed, not ten were then known. We may judge from these results of a single eruise, what still remains to be done in the department of Entomostraea. 


\begin{tabular}{|c|c|c|c|c|c|}
\hline III. CORYCAIDE. & Torrid. & torrid. & 2. Miracinæ. & Torrid. & Extra-torrid. \\
\hline 1. Corycæinæ. & & & Miracia, & 1 & 1 \\
\hline Corycæus, & 18 & 1 & & & \\
\hline Antaria, & 3 & $1(1)$ & Total CALANIDE, & 71 & $29(6)$ \\
\hline Copilia, . & 2 & & Total CrCLOPIDE, & 10 & $44(1)$ \\
\hline Sapphirina, & 15 & 5 & Total CORYCAID & 39 & $8(1)$ \\
\hline
\end{tabular}

The properly oceanic genera include all the Calanidae, excepting Diaptomus and Notodelphys; all the Corycaidar; with only the single genus Setella among the Cyclopidæ.

Among the Calanidæ, the genera are mainly tropical, yet each affords some extra-tropical species; and those which are most abundant in the colder waters are Calani or closely allied. Setella occurs beyond the tropics; but all the species thus far examined are found in the Torrid zone. Pontella is more of a warm-water genus than Calanus. The Corycæidæ are to a large extent tropical. The genus Corycaeus is almost exclusively so, while Sapphirina is common in the Temperate zone. The Steropinæ are Frigid species.

Although the Calanidre are more varied in species within the tropics, they abound more in individuals in the colder seas. Vast areas of "bloody" waters were observed by us off the coast of Chili, south of Valparaiso (latitude $42^{\circ}$ south, longitude $78^{\circ} 45^{\prime}$ west, and latitude $36^{\circ}$ south, longitude $74^{\circ}$ west), which were mainly due to a species of this group; and another species was equally abundant in the North Pacific, $32^{\circ}$ north, $173^{\circ}$ west.* They have been reported as swarming in other seas, constituting the food in part of certain species of whale. Such immense shoals we did not meet with, within the tropics.

Among the Daphnioidea, the genera Daphnella, Penilia, Ceriodaphnia, and Lynceus were observed by us in the Torrid zone. Of the Cyproids, Cypridina, Conchœcin, and Halocypris are oceanic forms, and mainly of the tropical oceans.

The Caligoids spread over both zones. Caligus and Lepeophtheirus reach from the equator to the frigid seas; Nogagus, Pandarus, and Dinematura are represented in both the Torrid and Temperate zones.

* The species in the former case was the Pontella (subgen. Calanopia) brachiata; and in the latter, Calanus sanguineus. 


\section{GENERAL REMARKS AND RECAPITULATION.}

We continue with some general deductions from the tables, and a recapitulation of some principles.

A survey of all the great divisions of Crustacea, shows us that exclusive of the Entomostraca, they are distributed, according to present knowledge, as follows:-

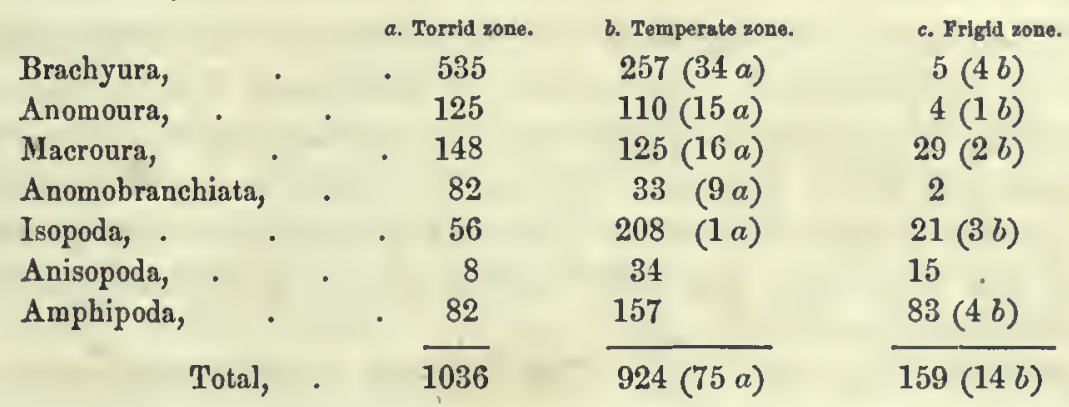

Taking the sum of the Frigid and Temperate zone species (subtracting the fourteen common to the two) we have 1036 species in the torrid regions to 1069 in the extra-torrid, seventy-five of which are common to the two. This shows a nearly equal distribution between the zones. But excluding the Brachyura, the numbers become 501 to 811, giving a preponderance of more than one-half to the Temperate zone.*

* Adding to the numbers above, the species which have been necessarily left out as of uncertain locality, amounting to one hundred and. forty in all, and inserting also the Entomostraca, it makes the total of described living species, as follows :-

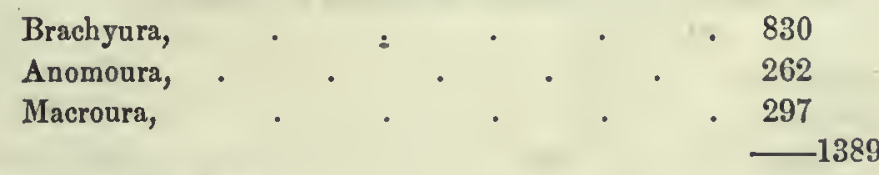

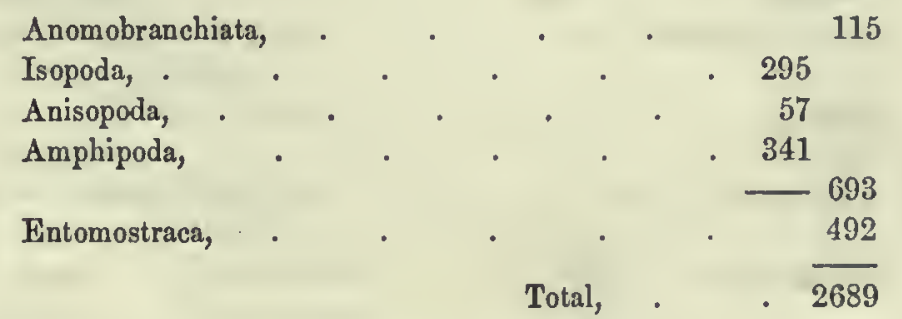

The number of species collected in the coursc of the cruise of the Expedition (exolu- 
The species of highest rank among the Brachyura, Macroura, Isopoda, and Amphipoda, the four principal types in the above, belong to the extra-torrid zones; and in subordinate groups or families, it is often true that the genera of superior grade are extra-torrid, in contrast with the others which arc torrid genera. Higher groups, characteristic of the colder regions, sometimes show degradation among those species of the group that are tropical; and the tropical sections also may continue the line of degradation by an extcnsion again into the colder seas.

As we descend in the scale of Crustacea, from the Podophthalmia to the Tctradecapoda, the number of cold-water species increases, becoming in the lattcr group, three times greatcr than the warm-water species. It is an important fact, nevcrthcless, that this increase of cold-water species is still no mark of degradation; the particular facts that have been discussed, leading to a very different conclusion. Other principles follow. These are-

First, that the two types, the Decapodan and Tetradecapodan, are distinct types, to be independently considercd, and not parts of a series or chain of species, a fact illustrated in the preceding chapter on the classification of Crustacea.

Second, that the preponderance of cold-water species is the reverse of what must have been truc in the earlier geological epochs, when the oceans had a somewhat higher temperature; or were to a large extent tropical.

Third, that the progress of creation as rcgards Crustacea, has ended

sive of those lost in the wreck of the Peacock, which included nearly all the collections of two seasons in the tropical regions of the Pacific) is nearly 900 ; and the number of new species described is 658, distributed among the groups as follows :-

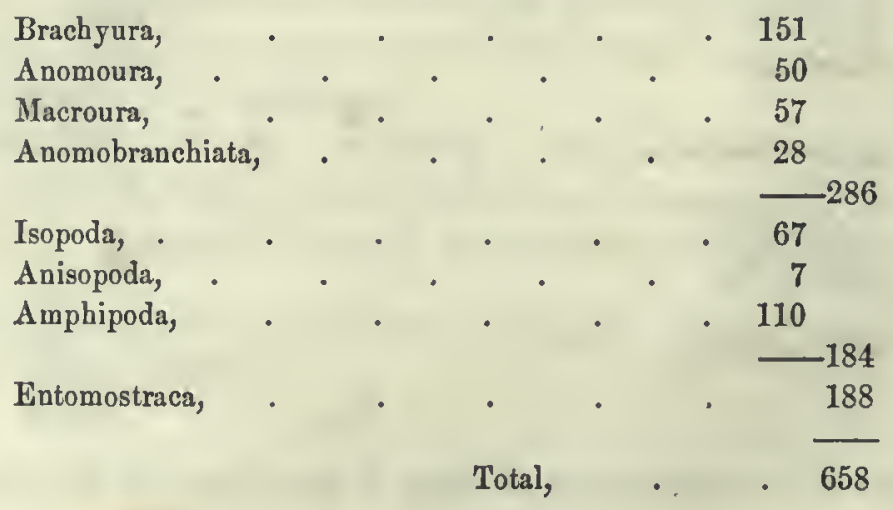


not where it begun, in multiplying the specics of warmer waters and giving them therc their superior devclopments, but in carrying species to a higher perfection in the colder regions of the oceans. A preponderance of spccics in the warmer seas is perhaps to be expected, since warm waters have prevailed even more largely than now in earlier epochs. But it would seem, that the introduction of the higher grades of Crustacea required, not merely the cooler waters of the present tropics, but even the still colder temperature of the Temperate zone, and therefore the present condition of the globe.

The genera of Fossil species commence with the Entomostracans and Trilobites in the Palæozoic rocks. Next appear certain Thalcussinidea and Astacoid species, in the Permian system; then Mysidea, Penaidea, many Thalassinidea, Astacoidea, and Anomoura, in the Oolitic system; then a few Cancroids and Leucosoids in the Cretaceous, which become much more numerous in the Tertiary system, along with some Grapsoids. None of the Maioids, the lighest of Crustacea, have yet been reported from either of the Geological epochs.

The number of individuals and the size are, for the Brachyura, greater in the Torrid zone than in the colder regions. But for the Macroura, the species of cold-water genera average nearly twicc the lineal dimensions of those of warm waters; and the number of individuals also may possibly be greater.

In stating the conclusion respecting the Macroura, on a preceding page (p. 1515), we omitted to give in detail the mean sizes of the different groups. The following are the results, including the Galatheidea, which are closely related to the Macroura:-

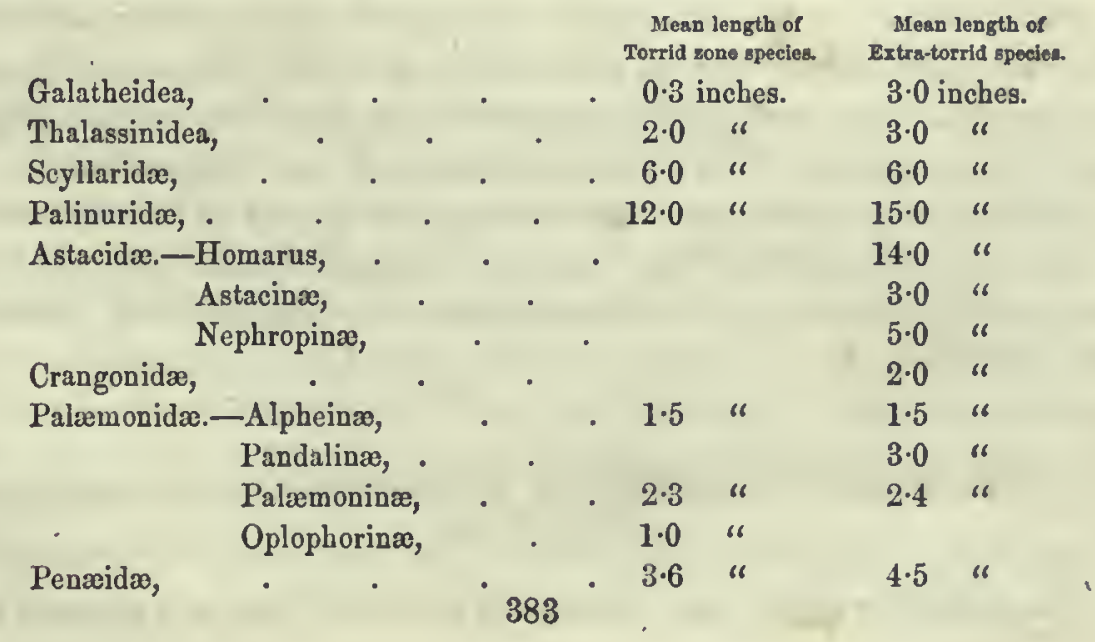


The table shows that the torrid species, in none of the groups, avernge larger than the extra-torrid. The cold-water Palinurida are as large as the largest warm-water species, and will outweigh them; the cold-water Galatheidea, are ten times the average length of the warm-water; the Alpheinæ, Palæmoninæ, and Penæidæ are at least as large in the temperate regions as in the torrid. There is hence nothing in the tropics to balance the Astacidæ, a group of large species, some of them gigantic; nor the Crangonidæ, nor Pandalinæ. The genus Palæmon, in the Torrid zone, averages larger than in the Temperate, the ratio being 3.5 to 2.40 ; the former amount being reduced to 2.3 for the Palæmoninæ, by the species of the other tropical genera, which are mostly quite small. Yet, taking the ratio of 3.5 to $2 \cdot 40$, it affects but little the balance against the Torrid zone.

As to bulk, also, the Temperate zone probably has the preponderance; yet our data are less definite. In the Galatheidea, the coldwater species are not only ten times larger lineally (which implies at least eight hundred times cubically), but they are far more prolific, swarming in vast numbers where they occur. The Thalassinidea are more numerous in extra-torrid species than torrid, as well as larger in size. The Scyllaridæ are mainly tropical; but the species are not of common occurrence, compared with the Astacidæ, which abound everywhere, and these, as well as the Crangonidæ and Pandalinæ, are all Temperate zone species. The Palæmoninæ and Penæidæ probably preponderate in the tropics, and this may be also true of the Alpheinæ. Taking a general view of the whole, and considering the fact, that the extra-torrid species rather outnumber the torrid, we believe that the deduction above stated is correct.

In the Tetradecapoda, the number of species, the number and diversity of genera, the number of individuals, and the bulk, are all greater in the extra-torrid seas than in the torrid, as has been explained on a preceding page; and this is especially true of the Amphipoda.

The tendency to spinose forms among the species of the colder temperate regions, or Frigid zone, has been remarked upon on page 1523, as exemplified among the Gammaridea, the Crangonidæ, Lithodes, and Maioids.

\section{DISTRIBUTION OF CRUSTACEA ACCORDING TO GEOGRAPHICAL PROVINCES.}

The following tables are presented, as embodying in a general way 
the greater part of the information furnished us by the present state of science, with reference to the distribution of Crustacea in the different parts of the globe.

We divide the surface of the globe, for marine zoological geography, into three sections, the Occidental, the Africo-European, and the Oriental; the first, including the east and west coasts of America and adjoining islands; the second, the eastern side of the Atlantic Ocean, the coasts of Europe, and also of Africa as far as the Cape of Good Hope; the third, embracing the Indian Ocean and its coasts and islands, the East Indies, and the Pacific Ocean, with its coasts and islands, exclusive of the western coast of America and the neighbouring islands.' The total number of species in each is given in a separate column.

In the Occidental section, under the head of Western America, there are two columns; one (N.) for the coast north of the equator; the other (S.) for the coast south, together with the Gallapagos.

Under the head of Eastern America, there are the same two divisions of north and south. Fucgia is included in Eastern instead of Western America.

In the Africo-European section, we make three columns; one (N.) for the coast of Europe and Africa, north of the equator; and the adjacent islands, the Cape Verdes, Canaries, and Azores; a second (Med.) for the Mediterranean Sea; a third, for the coast of Africa south of the equator to the Cape of Good Hope, with the islands, Ascension, St. Helena, and Tristan d'Acunha.

A separate column is devoted to species in the north frigid region of the Atlantic.

In the Oriental section, there are the divisions (1), East Africa, with the columns nortl (N.), and south (S.), the latter including Madagascar, Isle of France, and other islands near the African coast; (2), Indian Ocean and the Eust Indies, including the coast of Southern Asia, the islands of the oceans south, with Torres Straits and northwestern Australia; (3), the Western Pacific, including Japan and other regions north of the equator, for one column, and for the other, the islands and shores in the Western Pacific south of the equator, embracing New Ireland, Eastern Australia, Van Diemens Land; (4), the Middle Pacific, divided into north and south, and embracing the various islands over this ocean exclusive of those just mentioned, with New Zealand, the Aucklands, \&c., on the south.

Under each subdivision, we designate the particular temperature 
region in which the species occur, by using the letters $a, b, c, d, e, f$, $g, h$, as in the preceding tables. Thus opposite Libinia, $1 e$ in the first column means that one species occurs on the west coast of North America, and this one in the subtemperate region $(e)$, the position of which on the coast will be observed on the chart. So, opposite Hyas, $1 \mathrm{~g}$, in the same column, implies that one species occurs in the subfrigid region. These letters $a, b, \& c$. , in the columns in some cases have a more definite signification, than simply that of indicating the temperature region, for the reason, that species may have hitherto been obtained only at a single point in such a region. Thus in the column-

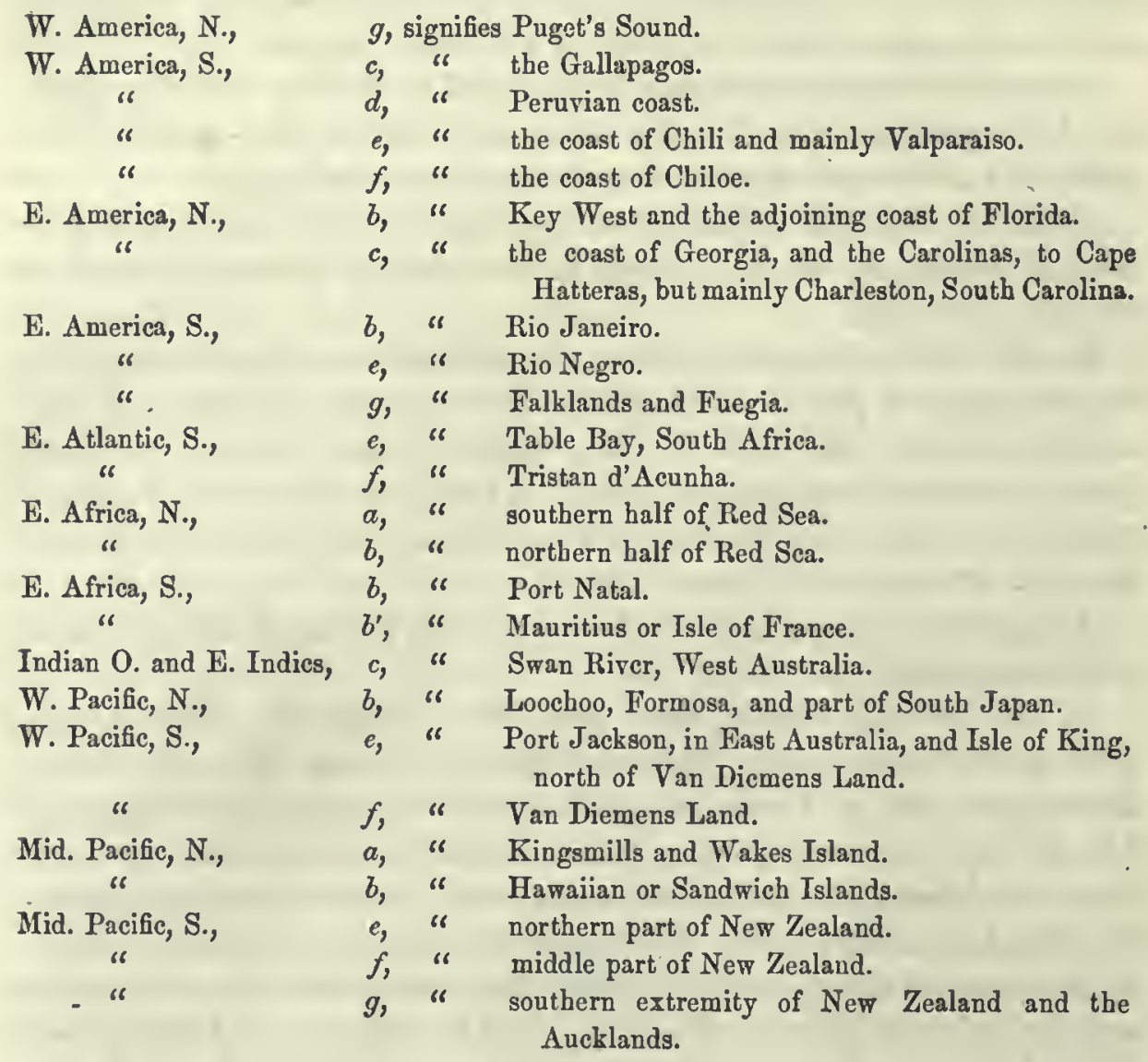

Other information respecting the use of the letters will be gathered from the Chart.

The order of the genera is the same as in the preceding tables, and the subdivisions into families may there be ascertained. 
GEOGRAPHICAL DISTRIBUTION OF CRUSTACEA. 1533

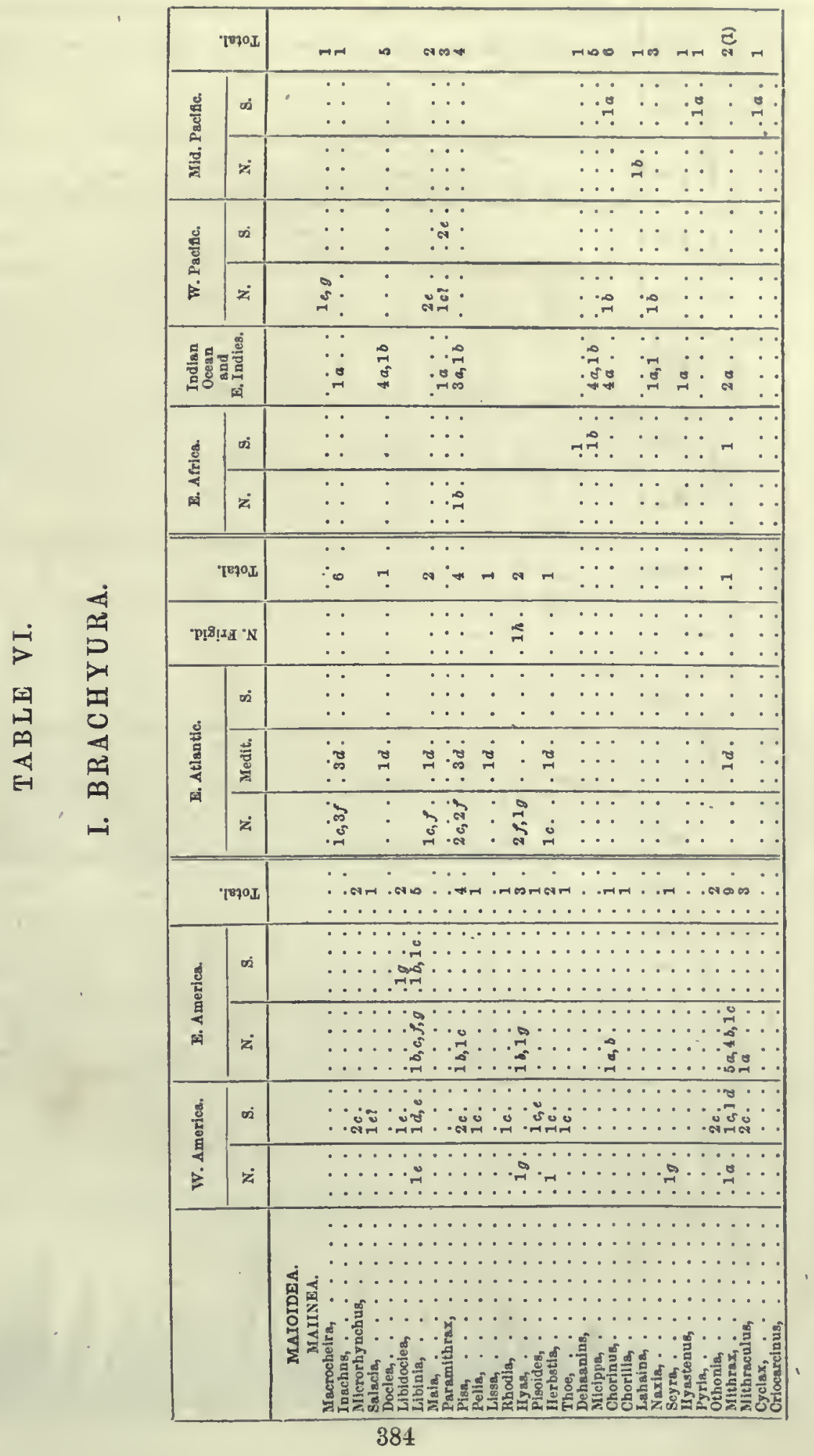


C R U S T A C E A.

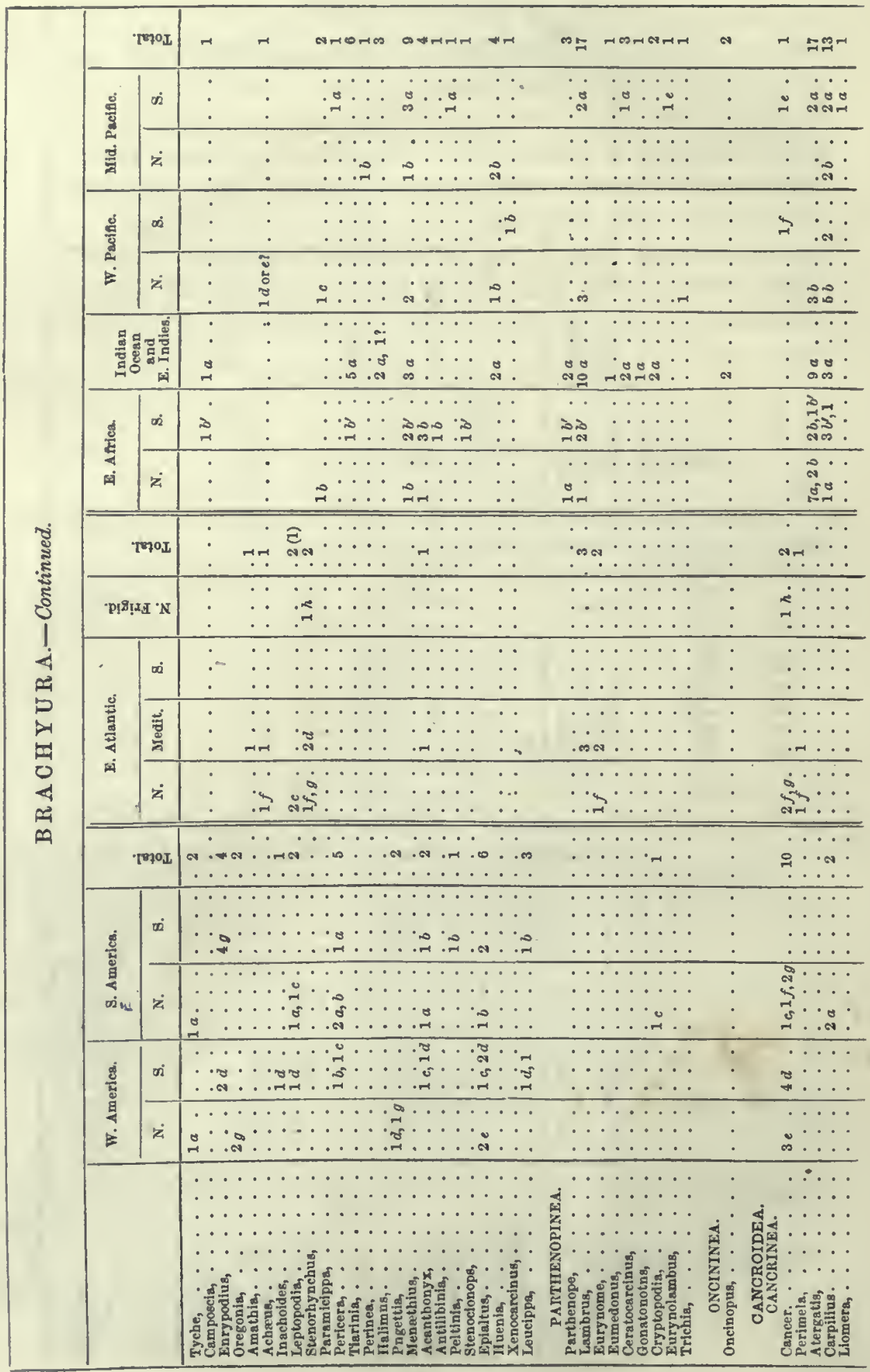


GEOGRAPHICAL DISTRIBUTION OF CRUSTACEA. 1535

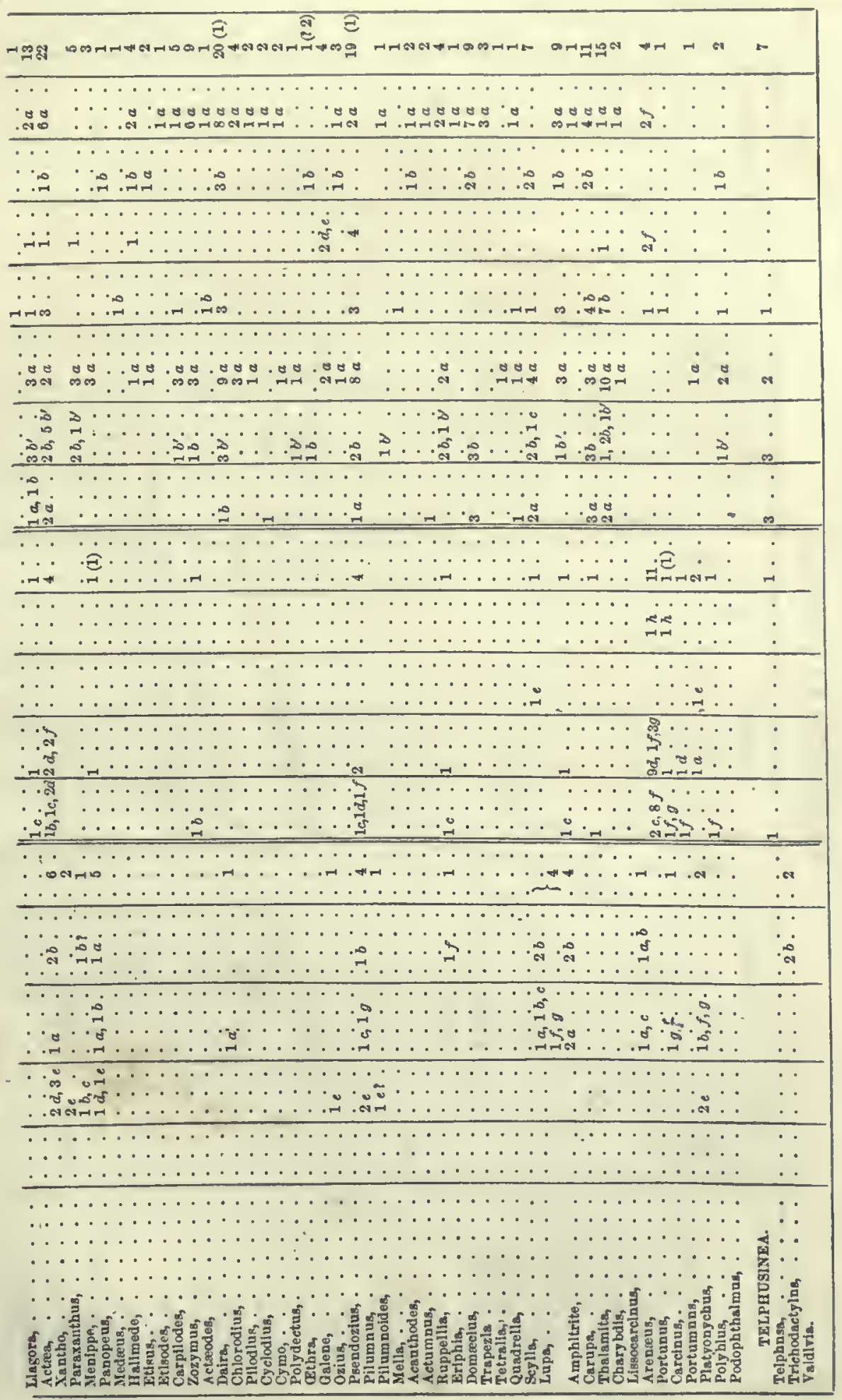


C R US T A C E A.

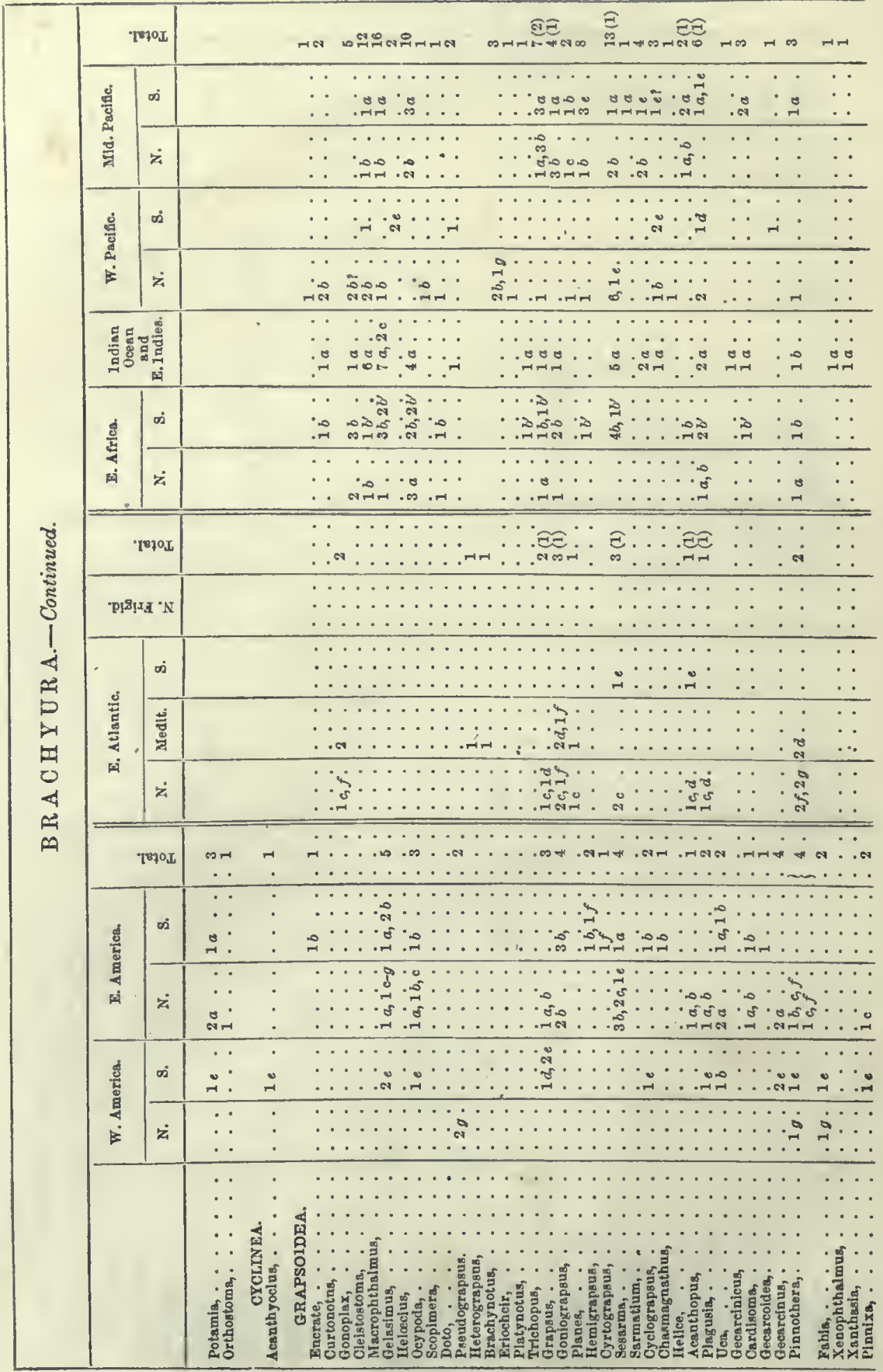


GEOGRA PHICAL DISTRIBUTION OF CRUSTACEA. 1537

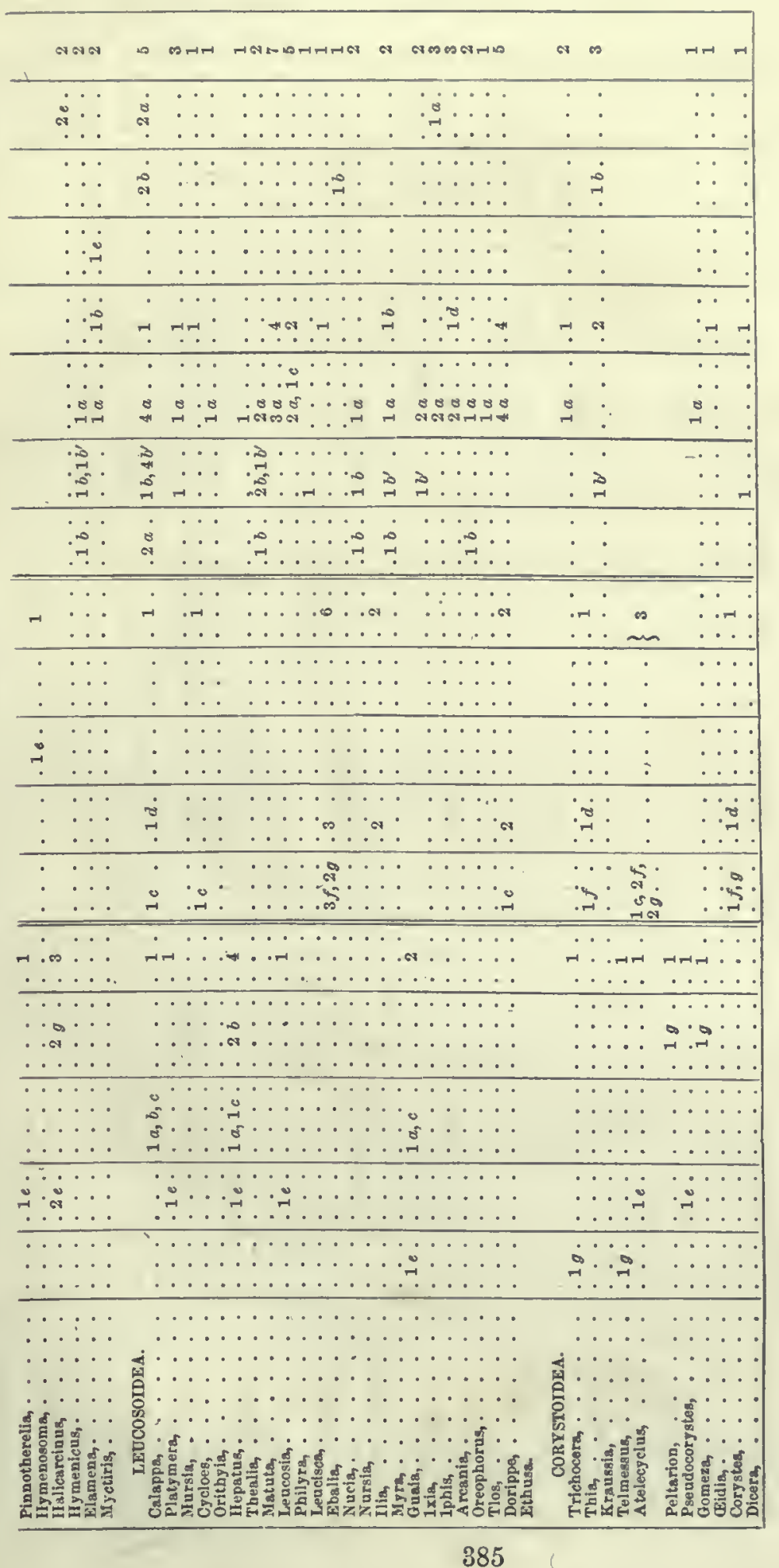




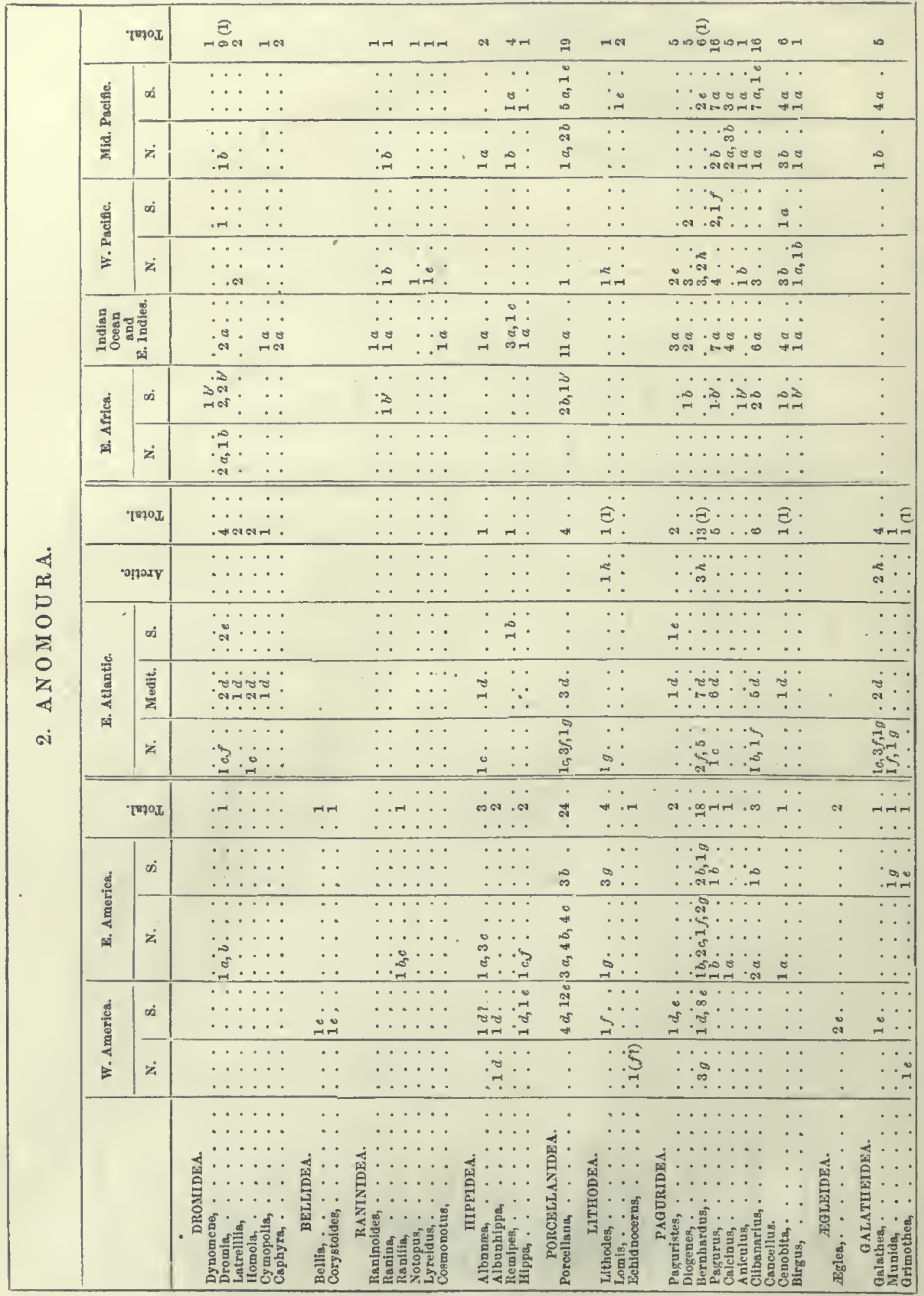


GEOGRAPHCAL DISTRIBUTION OF CRUSTACEA. 1539

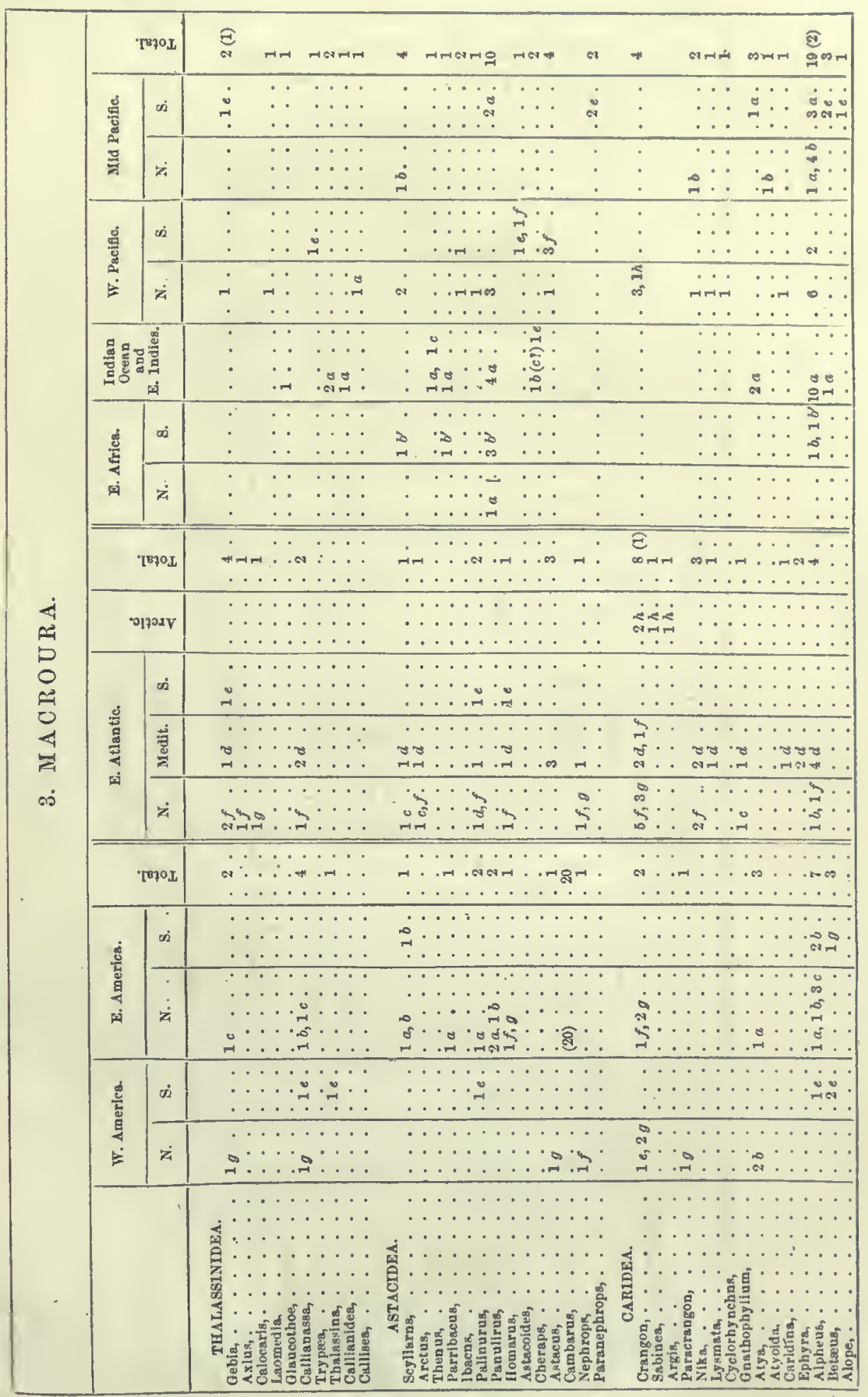




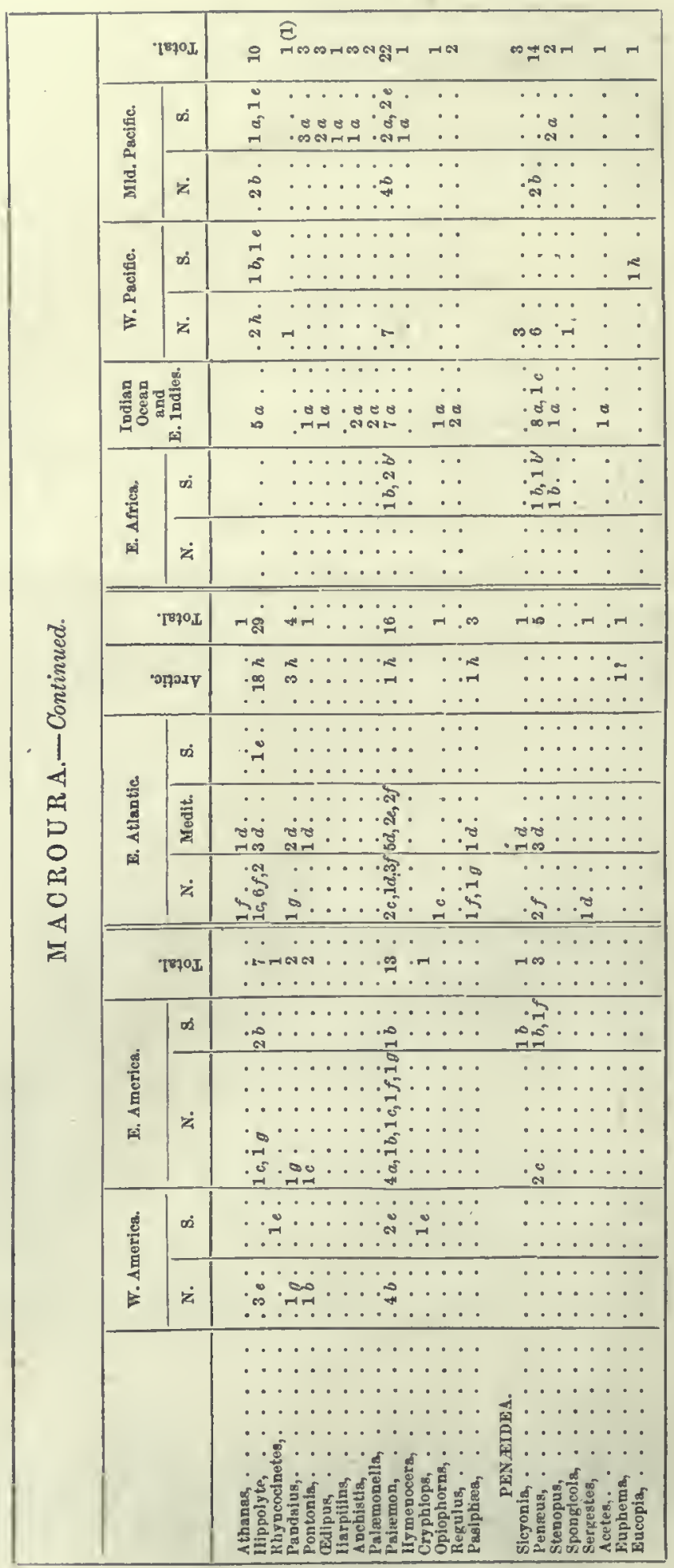


GEOGRAPHICAL DISTRIBUTION OF CRUSTACEA.

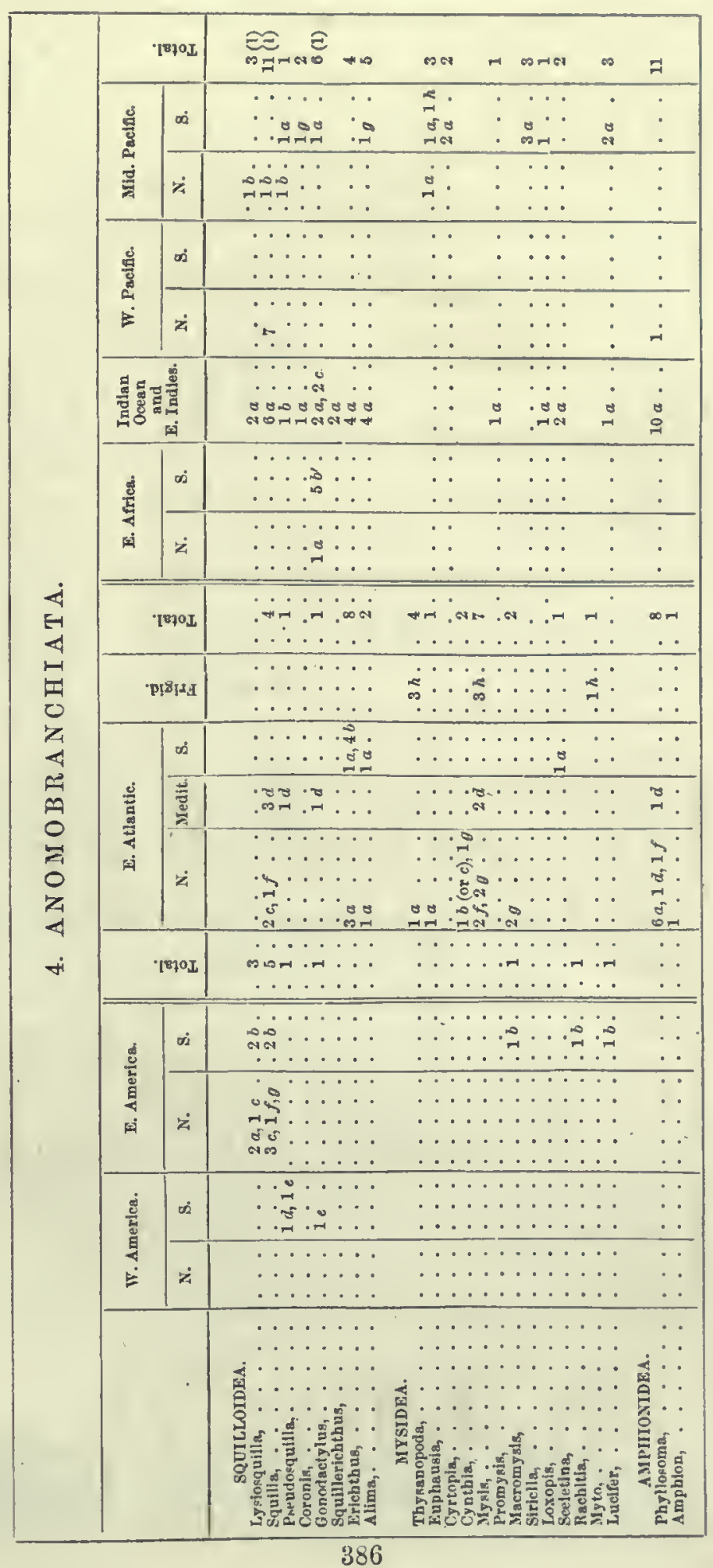


C R USTACEA.

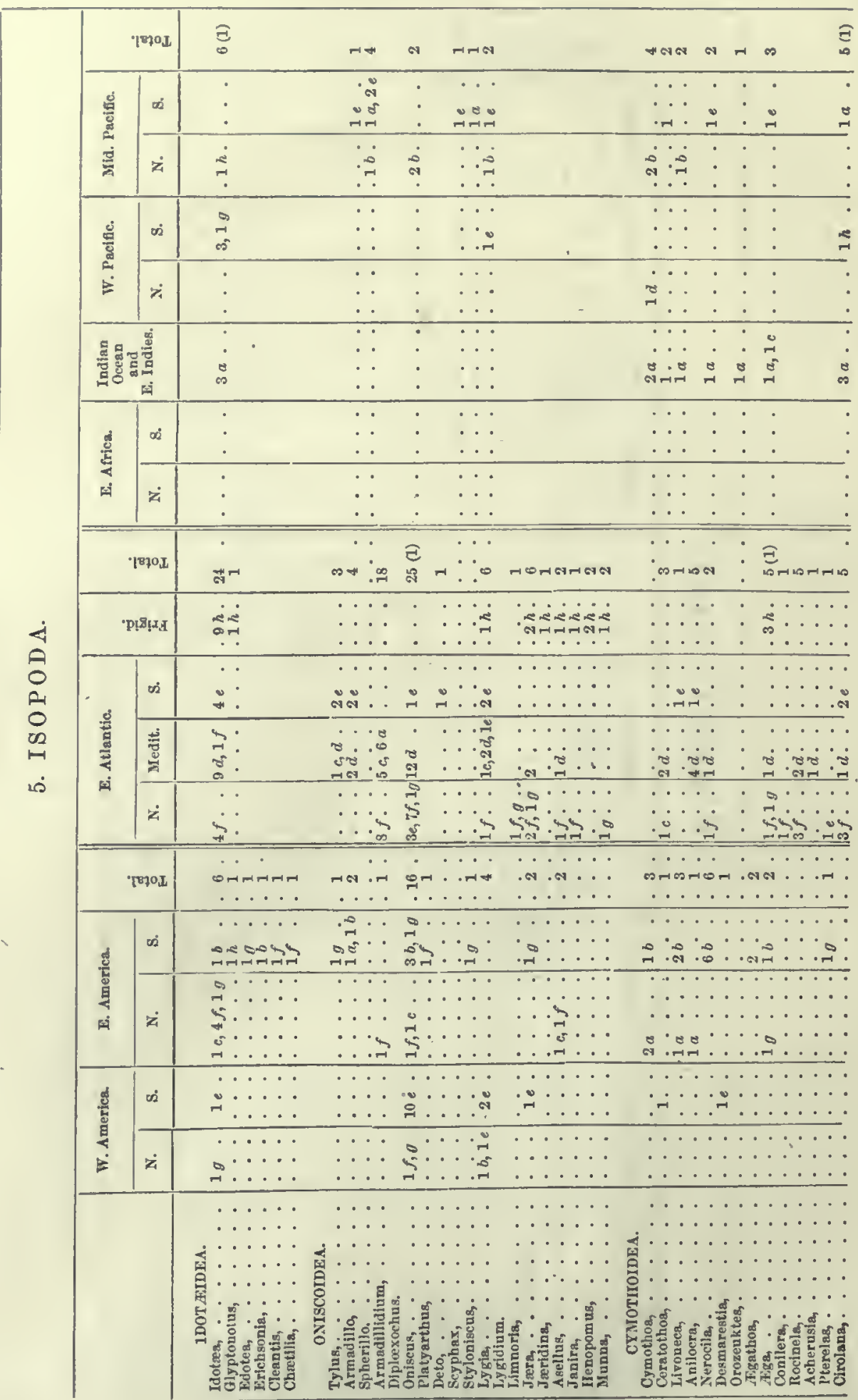


GEOGRAPHICAL Distribution OF CRUSTACEA. 1543

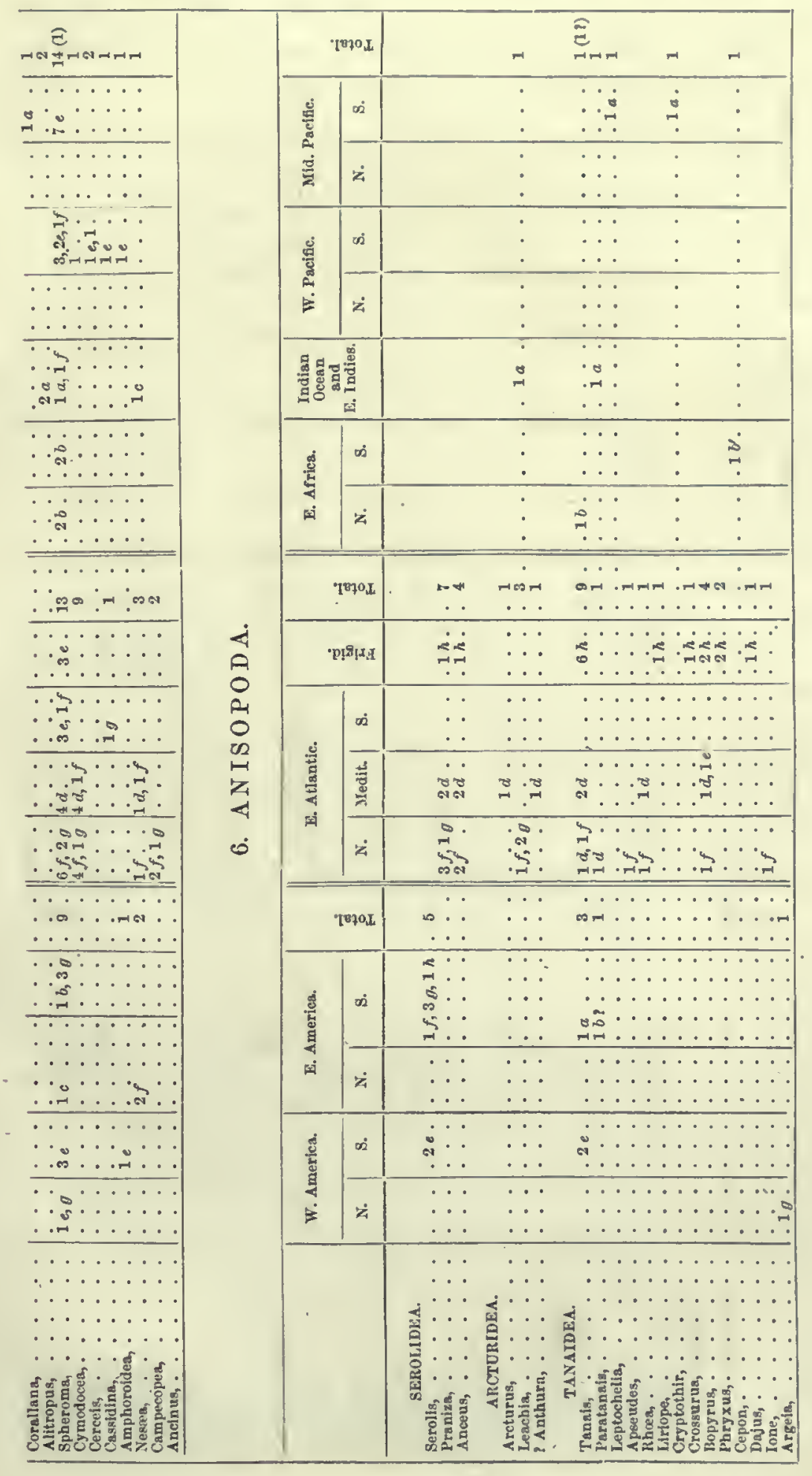




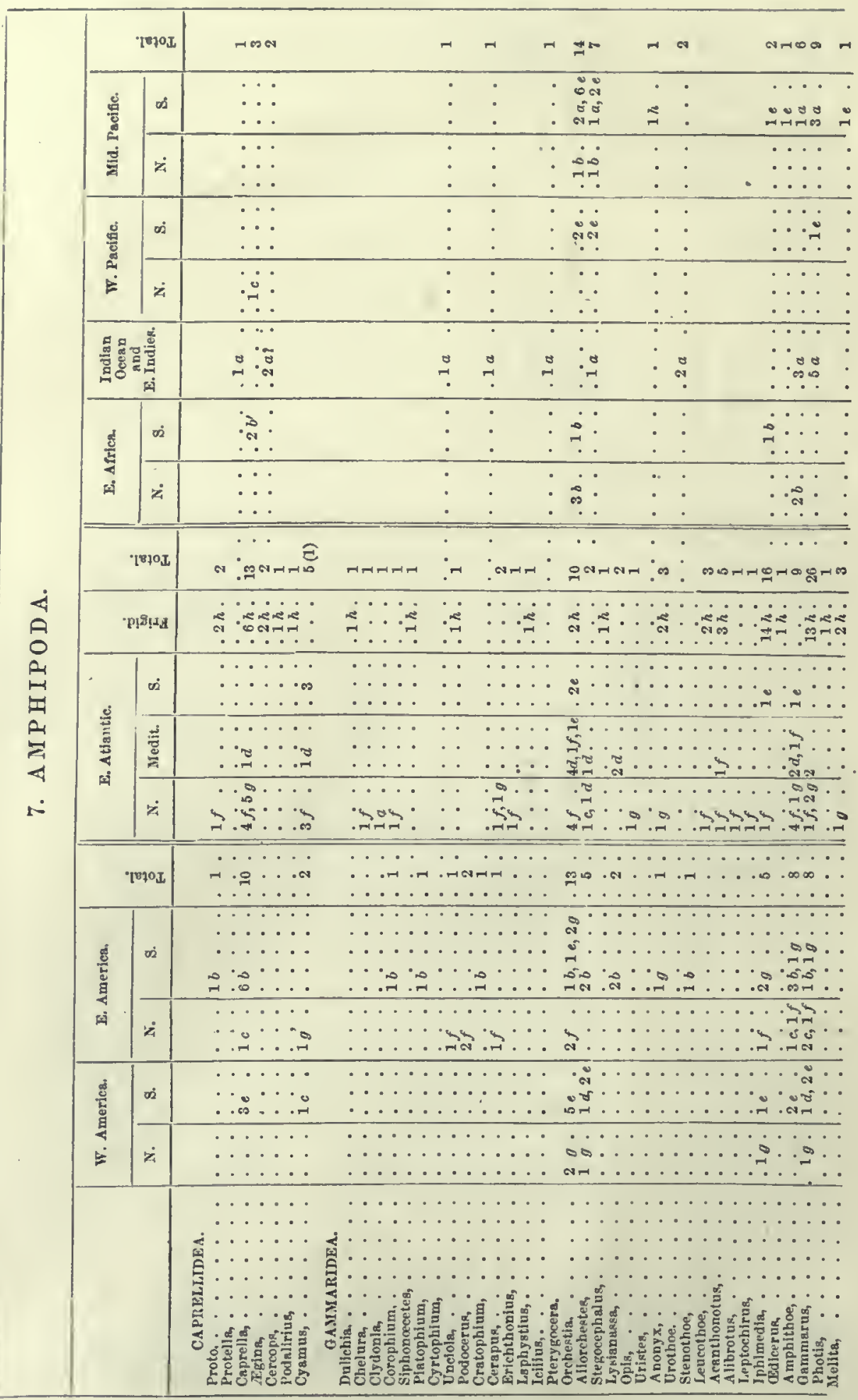


GEOGRA PHICAL DISTRIBUTION OF CRUSTACEA. 1545

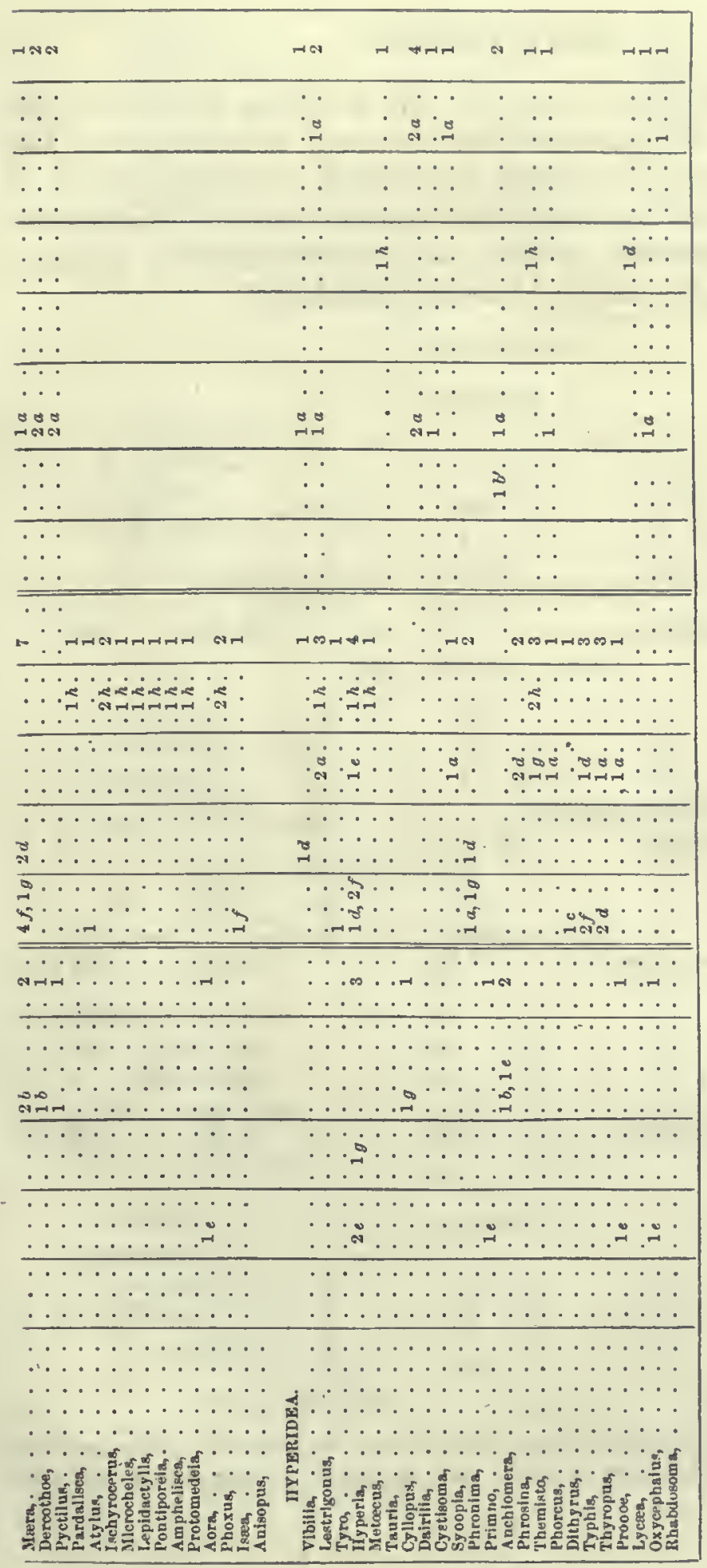




\section{RECAPITULATION.}

The three subdivisions adopted in the preceding table, are designated $\mathrm{A}, \mathrm{B}$, and $\mathrm{C}$, in the following summary of the results. The division $\mathbf{A}$, includes the Atlantic and Pacific coasts and islands of America; B, the European and West African coasts and islands, from Cape Horn to Greenland inclusive; and $\mathrm{C}$, the coasts and islands of the Indian and Pacific Oceans (America excluded).*

I. BRACHYURA.

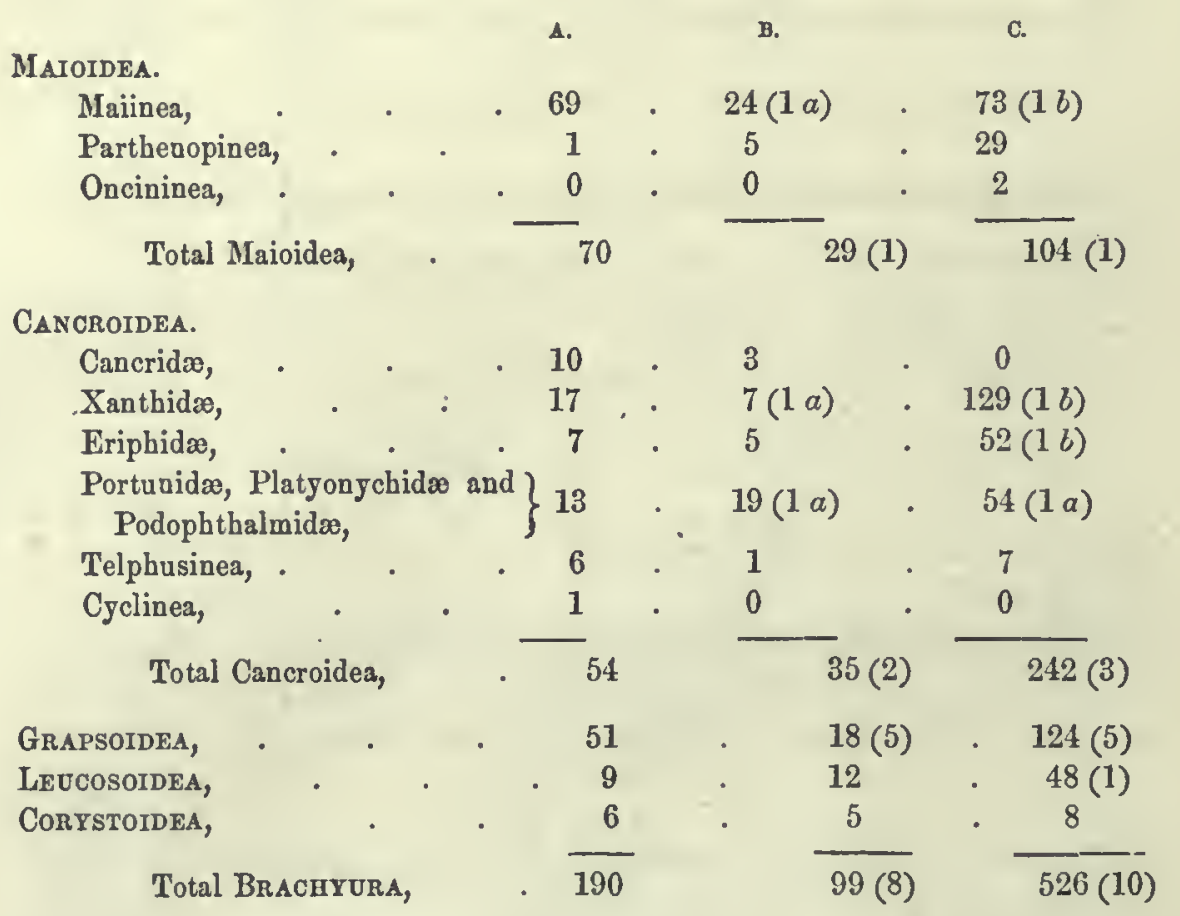

II. ANOMOURA.

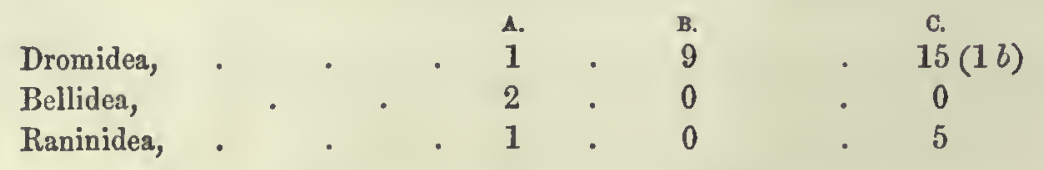

* The discrepancies between the enumeration here and the summarics of the preceding tables, arise from spccies omitted in onc or both, on account of the unccrtainty of their localities. 
GEOGRAPHICAL DISTRIBUTION OF CRUSTACEA. 1547

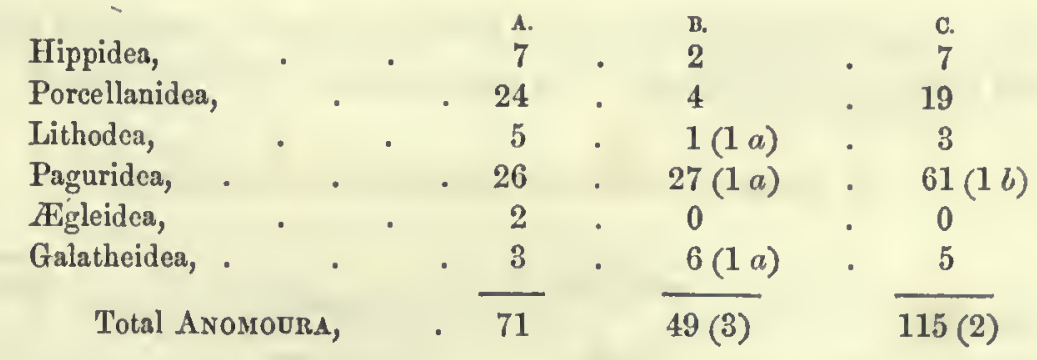

III. MACROURA.

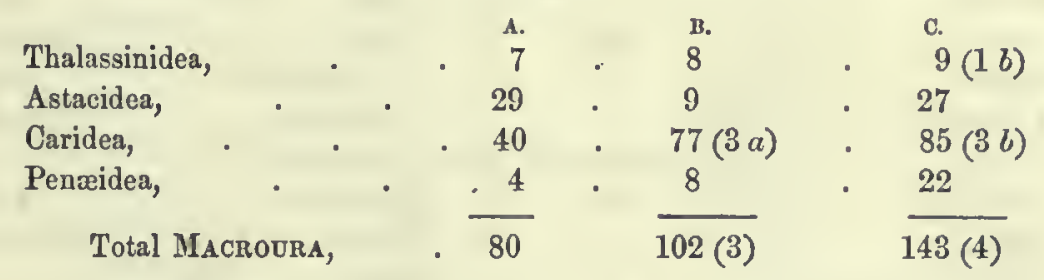

IV. ANOMOBRANCHIATA.

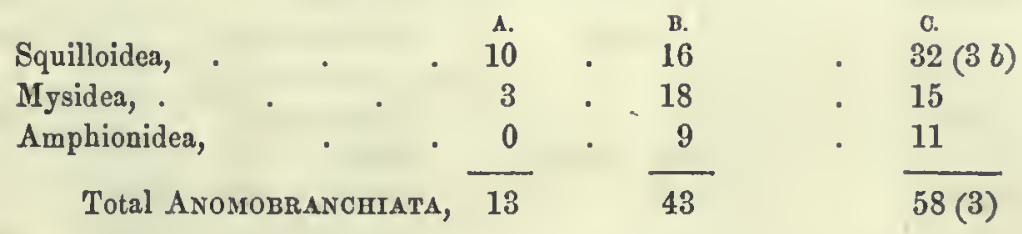

V. TETRADECAPODA.

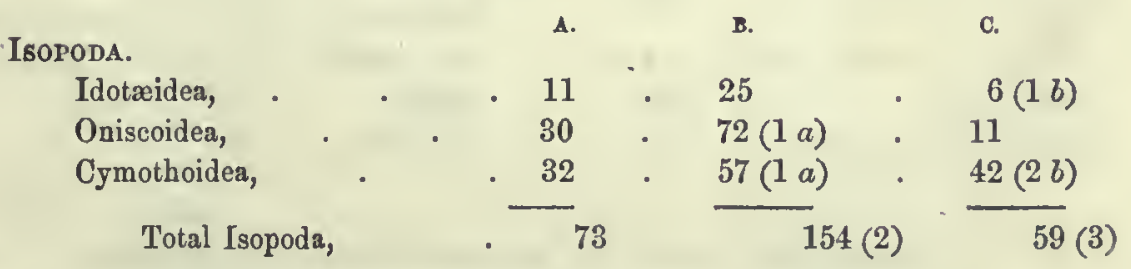

$$
\begin{aligned}
& \begin{array}{lllllll}
\text { ANISOPODA, } & \cdot & \text {. } & \text {. } & 10 & 38 & 6
\end{array}
\end{aligned}
$$


The preceding table affords the following lists of genera of the three grand divisions, according to the present state of the science.

1. GENERA EXCLUSIVEIY AMERICAN OR OCOIDENTAL.

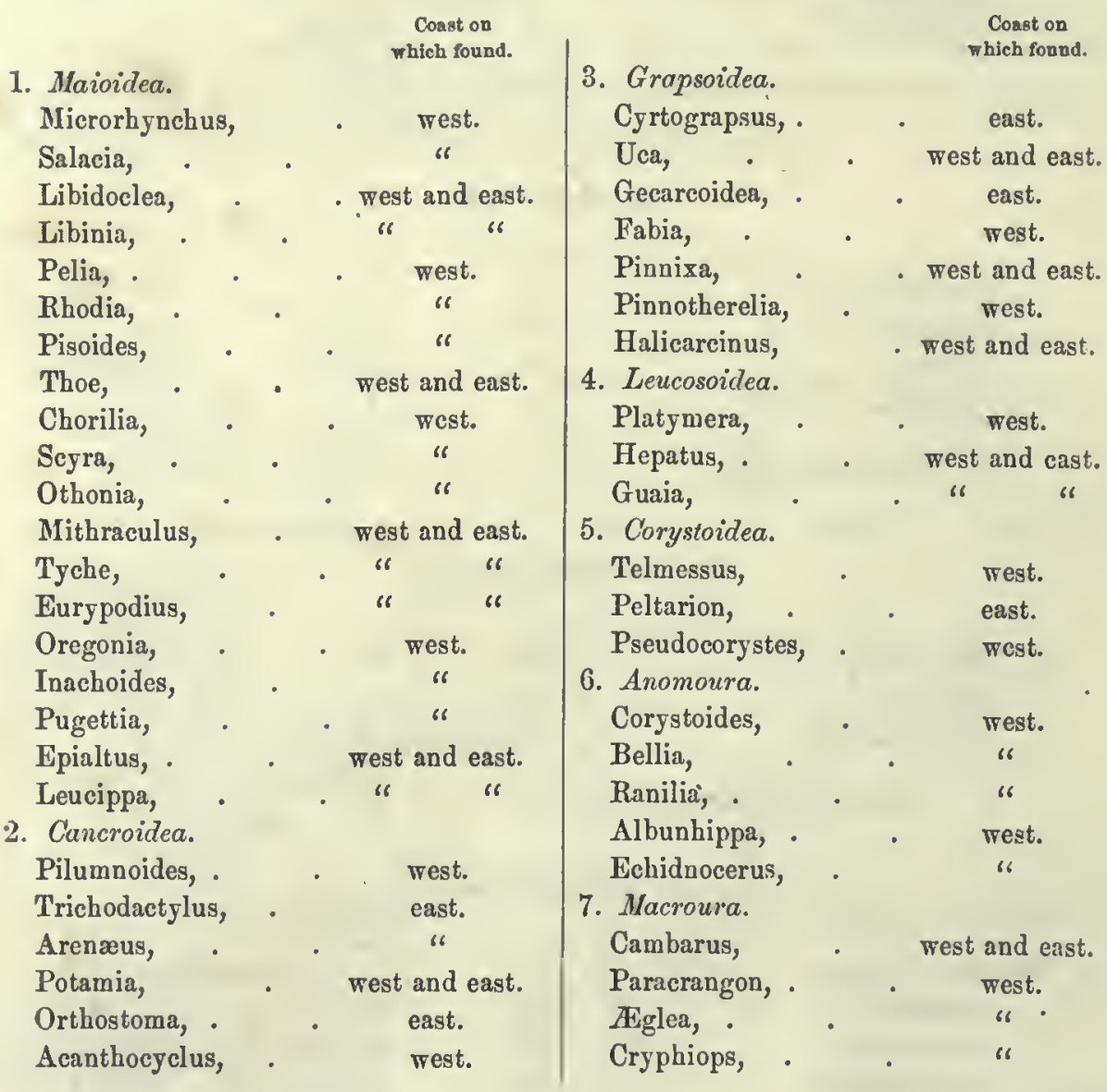

\section{GENERA EXCLUSIVELY OF THE AFRICO-EUROPEAN DIVISION.}

1. Maioidea.

Iissa.

Stenorhynchus.

Amathia.

Eurynome.

2. Cancroidea.

Perimela.

Portumnus.

Polybius.
3. Grapsoidea.

Gonoplax.

Heterograpsus.

Brachynotus.

Hymenosoma.

4. Leucosoidea.

Ilia.

5. Corystoidea.

Thia. 
Corystes.

6. Anomoura.

Homola.

7. Macroura.

Axius.
Calocaris.

Ephyra.

Gaathophyllum.

3. AENERA EXCLUSIVELY ORIENTAL, OR OF THE TIIRD DIVISION.

1. Maioidea.

Macrocheira.

Paranithrax.

Micippa.

Lahaina.

Naxia.

Hyastcnus.

Pyria.

Cyclax.

Camposcia.

Paramicippa.

Tiarinia.

Perinea.

Halimus.

Menæthius.

Stenocionops.

Hucnia.

Xenocarcinus.

Parthenope.

Eumedonus.

Ceratocarcinus.

Gonatonotus.

Eurynolambrus.

2. Cancroidea.

Atergatis.

Liomera.

Liagora.

Mcdæus.

Halimede.

Etisus.

Carpilodes.

Zozymus.

Daïra.

Cymo:

Polydectus.

Ethra.

Galene.

Pseudozius.
Melia.

Acanthodes.

Actumnus.

Ruppellia.

Domæcius.

Trapezia.

Tetralia.

Quadrclla.

Scylla.

Charybdis.

lissocarcinus.

Podophthalmus.

3. Grapsoidea.

Curtonotus.

Cleistostoma.

Macrophthalmus.

Heloecius.

Scopimcra.

Doto.

Eriocheir.

Platynotus.

Trichopus.

Sarmatium.

Helice.

Gecarcinicus.

Xenophtbalmus.

Xanthasia.

Hymenicus.

Elamena.

Myctiris.

4. Leucosoidea.

Mursia.

Orythia.

Thealia.

Matuta.

Philyra.

Leucisea.

Nucia. 
Nursia.

Myra.

Ixa.

Iphis.

Arcania.

Oreophorus.

Tlos.

Ethusa.

5. Corystoidea.

Kraussia.

Eidia.

Dicera.

6. Anomoura.

Caphyra.

Raninoides.

Ranina.

Notopus.

Lyreidus.

Cosmonotus.

Lomis.

Diogenes.

Aniculus.

Birgus.
7. Macroura.

Laomedia.

Glaucothoe.

Callianidea.

Callisea.

Thenus.

Ibacus.

Astacoides.

Paranephrops.

Cyclorhynchus.

Atyoida.

Alope.

Edipus.

Harpilius.

Anchistia.

- Palæmonella.

Hymenocera.

Oplophorus.

Regulus.

Stenopus.

Spongicola.

Acetes.

Eucopia.

4. GENERA COMMON TO THE AMERICAN AND AFRICO-EUROPEAN DIVISIONS, BUT NOT IN THE THIRD, OR ORIENTAL.

1. Maioidea.

Hyas.

Herbstia.

Leptopodia.

Stenorhynchus.

2. Cancroidea.
Atelecyclus.

3. Anomoura.

Munida.

Grimothea.

4. Macroura.

Homarus.

5. OENERA COMMON TO THE AFRICO-EUROPEAN AND ORIENTAL DIVISIONS, NOT YET FOUND IN THE OCCIDENTAL.

1. Maioidea.

Inachus.

Doclea.

Mais.

Achæus.

Lambrus.

2. Cancroidea.

Actæa.

Actæodes.

Thalamita.

Portunus.

Tclphusa.
3. Leucosoidea. Cycloes.

Ebalia.

Dorippc.

4. Anomoura.

Latreillia.

Cymopolia.

Remipes.

5. Macroura.

Nika.

Lysmata.

Caridina. 
6. GENERA COMMON TO THE THREE DIVISIONS.

1. Maioidea.

Pisa.

Mithrax (mainly Occid.)

Aeanthonyx.

2. Cancroidea.

Xantho.

Panopæus (mainly Occid.)

Pilumnus.

Eriphia.

Lupa.

Amphitrite.

Carcinus.

Platyonychus.

3. Grapsoidea.

Grapsus.

Goniograpsus.

Sesarma (sparingly European).

Acanthopus.

Plagusia.

Pinnothera.

Calappa.

4. Anomoura.

Dromia (sparingly Occid.)
Albunæa.

Porcellana.

Lithodes.

Paguristes.

Bernhardus.

Pagurus (mainly Oricnt.)

Clibanarius.

Galathea.

5. Macroura.

Gebia.

Scyllarus.

Panulirus.

Palinurus.

Astacus.

Crangon.

Alpheus.

Betæus.

Hippolyte.

Pandalus.

Palæmon.

Sicyonia.

- Penæus.

The following are lists of species common to two or more of the three divisions. They may be much changed by further study, through the discovery that the specimens from distant localities are not conspecific. Should this happen, there is a relation indicated based on their close similarity, which is important.

1. SPECIES STATED TO BE COMMON TO DIVISIONS A. AND B., OR THE AMERICAN AND THE AFRICO-EUROPEAN WATERS.

Hyas coaretata; Massachusetts and Long Island, in United States; Franee; England; Shetlands.

Leptopodia sagittaria; Canaries; West Indies; Valparaiso.

Panoperus Herbstii; Meditcrrancan; Kcy West, South Carolina, and New York, in United States.

Careinus mænas; Mediterrancan at Nice; Crimea; England; Massachusetts, United States.

Grapsus pictus; Madeira; Peru and Chili ; (also various Pacific islands.) 
Planes minutus; Atlantic Ocean, and occasionally found on both the American and European coasts.

Goniograpsus varius; Canaries; Mediterranean at Algiers, Nice, Italy; Crimea; Brittany; and probably at Rio Janciro, Brazil.

Sesarma reticulata; Key West and South Carolina, in United States; and in South Africa, according to M'Leay.

Acanthopus planissimus; West Indies; Canaries; Madeira ; Capc Town and Port Natal, South Africa (also various tropical Pacific islands).

Plagusia squamosa; West Indies; Key West, South Carolina, in United States; Canarics; Madeira (also, Isle of France; Indian Occan; Red Sea ; Port Natal).

Plagusia tomentosa; Chili; Cape Town (also, New Zealand).

Albunæa symnista; Canarics; Mediterranean (also, Pondicherry); and if the A. oxyophthalmus is the same species, it occurs in the West Indies, and on the coast of South Carolina.

Lithodes maia; Great Britain; Shctlands; Norway; coast of Massachusetts (rare).

Bernhardus streblonyx; Great Britain; France; Mediterranean; Norway; Massachusetts, in United States; (also Kamtschatka).

Cenobita diogenes; West Indies; Mediterrancan ; (Hawaii ?)

Crangon vulgaris; Great Britain; France; Unitcd States; San Francisco and Puget's Sound, Western America.

Crangon boreas; Norway; Iceland; Greenland; Massachusetts (in fish), (also, Kamtschatka).

Pandalus annulicornis; Scotland and Shetlands; Norway; Iceland; Massachusetts (rarc).

Gonodactylus chiragrus; Mediterranean; Key West; (also, Red Sea; Port Natal, South Africa; Isle of Frunce; East Indies; Swan River, Australia ; Pacific Ocean, at Feejees, Tongataku, \&c.)

2. SPECIES COMMON TO B. AND C., THE AFRTCO-EUROPEAN AND ORIENTAL SEAs.

Mithrax dichotomus; Mediterranean; East Indies.

Achrus Cranchii; Mediterranean; Japan (probably same species).

Actra rufo-punctata ; Canaries and Mediterranean; Isle of France, Indian Ocean.

Thalamita admete; Canaries; Port Natal, South Africa; Red Sea; Indian Ocean and East Indies; Pacific Ocean, at the Feejees, Samoa, Hawaiian

Pilumnus Forskalii; Canarics; Red Sea. Islands, Wake's Island, \&c.

Grapsus pictus; see above.

Grapsus strigosus; Canarics; South Africa; Red Sea; East Indies.

Goniograpsus messor; Canaries; Port Natal, South Africa; Red Sea; East Indies.

Planes minutus; Atlantic; Japan.

Acanthopus planissimus; see above.

Plagusia tomentosa; Chili; South Africa; New Zealand.

Plagusia squamosa; see above. 
Cycloes granulosa; Canaries; Japan (probably same species).

Remipes scutellata; Ascension Island; Swan River, Australia; St. Christopher's.

Lysmata scticaudata; Mcditerranean; Japan.

Alpheus Edwardsii; Meditcrranean; Cape Verdes; Port Natal, South Africa.

Pandalus pristis; Mediterranean; Japan.

Squilla mantis; Mediterranean; Canarics; Tschusan.

Pagurus striatus; Mediterranean; Japan.

\section{COSMOPOLITES.}

The above lists include the following species occurring in the Occidental, Africo-European, and Oriental seas.
Grapsus pictus.
Acanthopus planissimus.
Bernhardus streblonyx.
Plagusia squamosa.
Plagusia tomentosa.
Crangon boreas.
Crangon vulgaris.
Gonodactylus chiragrus.

These are cosmopolite species.* The Grapsus, Acanthopus, Plagusia squamosa, and Gonodactylus pre-eminently deserve this name, being found both north and south of the equator. They thrive in the hottest equatorial waters, and have their extreme limit in the temperate region. The temperature they admit of is hence at least from $56^{\circ}$ to $88^{\circ} \mathrm{F}$.

The other species are cold-water species. Plagusia tomentosa belongs to the southern subtemperate region, being reported from Cape Town, New Zealand, and Chili, and the rest are found in high northern latitudes, and probably pass from the Atlantic to the Pacific Ocean through the Arctic Seas.

Besides the above species, a few are found in the West Indies, which occur also in the Oriental Seas, but are not yet known from the European or West African coasts. These, which also may be styled cosmopolites, are as follows :-

Mithrax asper; East Indies; probably the same on the Peruvian coasts.

Atergatis lobatus; Red Sea and Indian Ocean; West Indies.

Carpilius maculatus; East Indies; South France; Japan; various Pacific Islands from the Paumotus to the Feejees and Hawaiian Islauds; West Indies.

- Eriphia gonagra; East Indies; Port Natal; Key West.

* The Platyonychus bipustulatus may possibly be another cosmopolite, for it is reported from Table Bay, the East Indies, Japan, and Valparaiso. But we believe the Valparaiso species to be different from that of the East Indies, and have so named it. 
Menippe Rumphii; East Indies; Rio Janeiro and the West Indies. Chlorodius exaratus; Pacific Islands; East Indies; West Indies. Lysiosquilla scabricaudis; Indian Ocean; West Indies; Brazil ; South Carolina.

From the survey already made, it is apparent, that the three grand divisions of the seas and coasts adopted in the preceding tablc, have very few species in common, and they correspond to a natural geographical arrangement. They constitute three kingdoms, to which two should be added, one for the Arctic Seas, and the other for the Antarctic. These kingdoms are:-

I. The Occidental Kingdom, embracing the Atlantic and Pacific coasts of America to the frigid region, or some point in the subfrigid region.

II. The European Kingdom, extending from Cape Horn (or Cape Agulhas) to the Shetlands inclusive, and embracing the adjoining islands.

III. The Oriental Kingdom, including the cast coast of Africa, the south and east of Asia, and the islands of the Indian and Pacific Ocean, exclusive of the American continent.

IV. The Arctic Kingdom, including Norway, Iceland, Grcenland, the Alascha Archipelago, and adjoining parts of the coasts of America and Kamtschatka, with other Arctic lands.

V. The Antarctic Kingdom, embracing. Fuegia, the Falklands, Southern New Zealand, and the lands or islands of the Antarctic Seas.

Each of the first three kingdoms are naturally divided into three subkingdoms: a north, a middle, and a south, corresponding severally to the North Temperate, Torrid, and South Tcmperate zones of seatemperature. The importance of these divisions will be a subject of further remark beyond.

The summary of the results in thc preceding table, presents some striking facts.

We observe, first, that there is a ratio of $1: 1.5$ between the Maioids of the $\mathrm{A}$ and $\mathrm{C}$ divisions (that is between those of the Occidental and Oriental seas, as just explained), while the ratio is about 1: $4 \frac{1}{2}$ for the Cancroids. So also, while the ratio of the A and B divisions together (Occidental and European) to $\mathrm{C}$ (Oriental) is for the Maioids, nearly $1: 1$, it is for the Cancroids, $1: 3$. Here is a wide difference between the Occidental and Oriental seas as regards these groups. This last ratio is for the Corystoids nearly that for the Maioids, or more exactly, $1: 0.75$; and for the Grapsoids it is 1:2; 


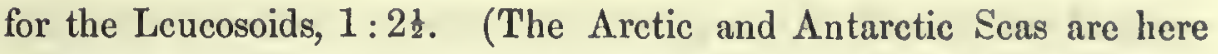
merged in the other kingdoms, with which they are most ncarly associated.)

If we compare these ratios with those which the same groups sustain as regards temperature, as exhibited on a former page, we discover that thcre is a very close parallelism; showing plainly that the prevalence of Maioids in the Occidental Seas must be owing to the comparative prevalence of cold watcrs; and the prevalcnce of the warmwater groups, the Cancroids and Leucosoids, in the Oriental Seas, is owing conversely to the grcat extent of warm waters.

Again, the ratio between the $A$ and $B$ divisions together of the Macroura, and the $\mathrm{C}$ division, is nearly as $1: 0 \cdot 8$, which sustains the same conclusion.

The corresponding ratio for the Tetradecapoda is as $1: 0 \cdot 26$. But as this group, owing to the smallness of the specics, lias not been thoroughly investigated, except in European regions, directly under the eyes of European observers, we cannot use satisfactorily the facts they present for deducing general conclusions, or for characterizing zoological districts or provinces. Still, it should be observed that the facts conform to the same principle.

It is hence of the highest importance bcfore comparing the zoological character of different coasts, that thc temperaturc-regions of those coasts should be ascertained.

Comparative tables of the East Indies and Mediterranean, or of the Peruvian coast and the East Indies, or of the southeast and southwest coast of Africa (and so on), would lead us far astray, if this element were left out of view; for a difference of temperature rcgion, implies a difference of genera and specics, independent of other considerations. On these grounds, whole continents, or sides of contincnts, may have a common character and differ widely from other continents in the same latitudes.

If we look at the American continent in this point of view, we at once perccive a striking peculiarity. All the coasts of North and South America, with the Gallapagos on the west, belong to the Tcmperate zone, excepting a few degrees along by Panama, and a connicted range of coast from Key West to Rio Janeiro. Chili and Peru are excluded even from the warm temperate region, and so also, the coast of the United States, north of Cape Hattcras.

Now contrast America with the Oriental Scas. The whole east 
coast of Africa, north of the parallel of $30^{\circ}$ south, the coasts of India and the East India Islands, and the northern half of Australia, together with the numerous islands of the Pacific, belong alike to the Torrid zone. In the American Seas, the torrid coasts make a single range, and have many species in common througliout. In the Oriental Seas, they reach with an uninterrupted surface over one-half of the circumference of the globe, and there is room for many distinct provinces within the same tcmperature region. The space for Torrid zone species along the American coasts in the Atlantic or Pacific, or that of the whole Atlantic Ocean, is small compared with the vast extent of the East Indies, Indian Ocean, and Middle Pacific, and this fact is more striking, if we consider that the Atlantic east of the West Indies contains no islands in the Torrid zone, besides St. Helena, Ascension, and the Cape Verdes, all of which are of small size.

Again, in order to compare the coasts of America and Europe, we must observe that the warm temperate region is represented along the former by a small district from Northern Florida to Cape Hatteras, while this region does not reach at all the latter, and only the Canaries in the eastern Atlantic are within it. Moreover, the temperate and subtemperate regions are mere points on the North American coast at Capc Hatteras; while on the European side, the former embraces the larger part of the Mediterranean, and a portion of Northwestern Africa, and the latter includes the Atlantic coast of Portugal. But north of Cape Hatteras, the coast of America is rightly compared with that of Europe, north of Portugal.

To compare the coast of Asia and Europe, we first observe in the same manner the temperature regions. There is in fact a striking sinilarity with the coast of the United States. Yet, the torrid and subtorrid regions are confined to limits much nearer the equator; and the warm temperate, although embracing as many degrees of latitude as the warm temperate on the United States, does not on the China coast extend farther north than the subtorrid region of the Florida coast. The temperate region liardly has a place on the coast of China, while the subtemperate occupies the Yellow Sea. North of this Gulf, the coast corresponds mostly with the coast of the United States, north of Cape Cod.

It is unnecessary to adduce other cxplanations, as the chart furnishes all that is necded for a ready comparison between the different coasts. 
The propriety of uniting in one kingdom both coasts of America, the eastern and western, and thus shutting off the latter from the great Pacific Oeean, may at first appear unnatural. Yet it is supported by all facts bearing on the subject. There are no species known to be eommon to Western America and the Middle Pacific, excepting two or three cosmopolites. Moreover, the genera are to a great extent distinct, and where so, they often occur on both sides of the continent. The genera of Podophthalmia peculiar to America are mentioned on page 1548, and also the particular coast on which they oecur.

A review of some of the faets will exhibit in a strong light the zoologieal resemblances of the two sides of the continent.

Of Cancer, there are four speeies found on the west coast of South America, three on the west eoast of North America, and two on the east coast of North America.

Of Hepatus, there is one speeies common to the West Indies and Brazil, a second, found at Rio Janeiro; a third, at Valparaiso, Chili ; a fourth, on the Carolina eoast.

Libinia, in the same manner, has its species on the Atlantie and Paeific coasts of the United States, and the eoasts of Western and Eastern South America. Mithrax is as widely distributed.

Epialtus occurs in the West Indies, California, Brazil, Gallapagos, and Valparaiso. Potamia has two West Indian and one Chilian speeies.

Eurypodius of Southern South America has its representative at Puget's Sound, in the genus Oregonia.

Again, the Libinia dubia of the West Indies, is hardly distinguishable, according to Prof. L. R. Gibbes, from the L. affinis, Randı, of the California coast. L. spinosa of Brazil is also found in Chili. Lepto podia sagittaria oecurs in the West Indies, and also, according to Bell, at Valparaiso; Acanthonyx Petiverii (?), in the West Indies, Brazil, and Gallapagos; Epialtus marginatus, on the eoast of Brazil and at the Gallapagos (Bell); Epialtus bituberculatus, in Chili, and at Key West; Uca una, Guayaquil and West Indies; Albunoea scutellata, West Indies and San Lorenzo, Peru; Hippa emerita and talpoides, both on East and West Ameriea, North and South.

It is obvious, therefore, that the east and west sides of America are very elosely related, and differ widely in a zoologieal sense, from either of the other kingdoms.

We observe further, that nearly all the genera peculiar to America are cold-water genera. They are mostly Maioids; the large group of 390 
the Cancroids, which belong mainly to warm waters, does not include a single genus exclusively American, and of the family Leucosidx, of the Leucosoids, there are only three known species.

We also perceive why the western coast of America has no zoological affinity with the Pacific Islands. The temperature of their waters is widely different; and, moreover, the oceanic currents of the tropics run from the American coast to the westward, and are a barrier to migration eastward.

The relations of the American or Occidental to the Africo-European kingdom are of much interest. The two kingdoms are widely different in most respects.

In the first place, the genera Lupa, Gelasimus, Ocypoda, Libinia, Epialtus, Hepatus, well represented on the American coasts, are not known on the European, besides others (Table 1, page 1548) of less prominence.

Again, there are several genera common in Europe, not known in America, as Inachus, Maia, Achous, Portunus, Ebalia, Latreillia, Athanas, in addition to those included in Table 2, on page 1548.

Still, the American and Africo-European kingdoms have a common character separating them from the Oriental. For example: the great genus Cancer occurs in both of these kingdoms, and is not known in Oriental seas, except in New Zealand and Tasmania. So also the important genus Homarus; besides Hyas, Herbstia, Leptopodia, Atelecyclus, Munida, and Grimothea. The genus Homarus has one species on the coast of the United States, one on the coast of Europe, and one at Table Bay, South Africa, thus ranging over the whole Atlantic.

We may now treat separately of the several Kingdoms, and their subdivision into Provinces, pointing out the naturalness of their limits, and the characteristics of these Provinces. Each temperature region along a coast makes a distinct Province, which facts, where ascertained, show to be well characterized. In some cases, a farther subdivision may be desirable, and when so, the subordinate divisions may be called Districts. The Provinces of each zone together may constitute a Subkingdom, as the Torrid Subkingdom, Temperate Subkingdom, \&c. 


\section{OCCIDENTAL KINGDOM.}

In the Occidental kingdom, there are in the first place, two SEctions, the Eastern and the Western; and both these sections are subdivided into-

1. The Torrid Subkingdom; 2. The South Temperate Subkingdom; 3. The North Temperate Subkingdom. The last two subkingdoms include the whole of the Tcmperate zone, excepting perhaps the extreme portions, which on zoological grounds may be separated, and united to the Frigid zone, forming the Arctic or Antarctic kingdoms.

In the following mention of the provinecs, we give their lengths along the const; and it will be seen, that although they may appcar to be numerous, they still have a wide extent, the length being seldom under five hundred miles, and sometimes full four thousand miles.

\section{A. WESTERN SECTION.}

I. TORRID SUBKINGDOM.

1. The Panama Province (torrid), extending from the equator or a degree south to a degrce beyond Acapulco. Length, sixtecn hundred miles.

2. The Mexican Province (north subtorrid), reaching from the ternination of the Panama province to the Peninsula of California. Length to the California Peninsula, exclasive of the Gulf, six hundred miles.

3. The Guaraquil Province (south subtorrid) occupying from Cape Blanco, the west cape of South America, nearly to the equator, and including the Bay of Guayaquil. Leugth, nearly two hundred miles.

\section{SOUTH TEMPERATE SUBKINGDOM.}

1. The Gallapagos Province (warm temperate) includes the Gallapagos Islands, but does not reach the continent. The genera peculiar to it are Microrhynchus, Pelia, Rhodia, Thoe, and Othonia. There are also two species of Mithraculus, one of Mithrax, one of Pisoides (also 
Chilian), one of Herbstia, one of Pisa, one of Epialtus. The variety of Maioid forms is remarkably large. The Cancroids have not been described. Epialtus marginatus is also reported from Brazil.

2. The Peruvian Province (temperate), from just north of Payta nearly to Copiapo. Length, fifteen hundred miles. The most characteristic species appear to be the Panopous crenatus, Xantho crenatus, and Albunhippa spinosa (another species of which genus occurs in California). There also exists here, the cosmopolite Grapsus pictus, of very large size, which is rare farther south; also Libinia rostrata, Mithrax asper, Acanthonyx emarginatus, Porcellana mitra, Paguristes Weddelii; besides several Chilian species of Porcellana, and Xantho Orbignii, $X$. Gaudichaudii, Bernhardus Edwardsii, and Psendosquilla monoceros, which are common to Chili and Peru. The Pilumnoides perlatus is reported from Peru by D'Orbigny; but we observed it only at Valparaiso, where it was originally found by Poppig.*

3. The Chilian Province (subtemperate). Length, seven hundred miles. This province is distinguished from the Peruvian by the rare occurrence of Grapsus pictus, and the unusual number and size of the species of Cancer and Porcellana, three of the former and ten of the latter existing at Valparaiso. Both of these genera have been shown to reach their highest developments in the middle Temperate zone. Other characteristic genera are the following:-Inachoides, Acanthocyclus, Platymera, Pseudocorystes, Bellia, Eglea, Cryphiops, Pinnotherelia, and Rhyncocinetes. Epialtus dentatus, Ocypoda Gaudichaudii, Grapsus planifrons, Hepatus chilensis, and Platyonychus purpureus are large and common species. The genera Ocypoda and Grapsus are not found south of the subtemperate region. Pilumnoides we suspect to be peculiar to Chili. The following are other genera represented in the Chilian seas:-Libinia, Libidoclea, Pisoides, Leptopodia, Leucippa, Xantho (four large species), Panopous, Ozius (also an Australian genus), Pilumnus, Gelasimus, Cyclograpsus, Uca, Pinnixa, Leucosia, Atelecyclus, Paguristes, Bernhardus, Galathea, Callianassa, Thalassina, Alpheus, Betaus, Palarmon, Pseudosquilla, Gonodactylus.

The Chilian province is allied to the Gallapagos through Pisoides tuberculosus and perhaps, Acanthonyx Petiverii; with Brazil, through Libinia spinosa; with the West Indies and Canaries, through Leptopodia sagittaria. The Hepati of Chili and Rio Janeiro are closely related; and we suspect that the H. chilensis is found also at

* Gay, in his Historia de Chile, mentions its occurrence only on the Chilian coast. 
Callao, Peru. The Eurypodii of the Patagonian seas sometimes reach as far north as Valparaiso.

Among the Tetradecapoda, Amphoroidea typica is a peculiar species, yet it closely resembles a species from Australia. Other genera of Tetradecapoda represented in Chili, are the following:-Epelys, Purcellio, Lygia, Spheroma, Desmarestia (Nicolet), Orchestia, Allorchestes, Iphimedia, Amphithoe, Aora, Hyperia, Primno, Pronoe, Oxycephalus.

4. The Araucanian Proviince (cold temperate), extending from Valdivia nearly to the parallel of $50^{\circ}$. Length, nine hundred miles. The genera Eurypodius and Lithodes occur on this coast, and probably also Platyonychus and Pseudocorystes; but the Araucanian species have not yet been studied.

South of the Araucanian province lies the South Patagonian and Fuegian, the latter of which properly falls into the Antarctic kingdom.

III. NORTH TEMPERATE SUBKINGDOM.

1. The Sonora Province (warm temperate) along the California Peninsula. Length, five hundred and fifty miles.

2. The Drego Province (temperate), extending from just below the entrance of the Peninsula, in latitude $28 \frac{1}{2}^{\circ}$ to latitude $34 \frac{1}{2}^{\circ}$, and including the port of San Diego. Length, four hundred and fifty miles. A species of the genus Pugettia and an Albunhippa (a Peruvian genus) occur on this coast.

3. The Californian Province (subtemperate) extending beyond the Bay of San Francisco to Cape Mendocino. Length, four hundred and eighty miles. This region has a close resemblance to the Chilian, in some of its genera, which is also subtemperate. Thus there are three species of Cancer, two of Epialtus, and one of Libinia. The Libinia is closely like the $L$. dubia of the United States, if not identical with it.

4. The Oregon Province (cold temperate), extending probably to Puget's Sound. Length, about four hundred and eighty miles. The Crangon vulgaris, common in Northern Europe, occurs on this coast, and the Echidnocerus of White (near Lithodes) is reported from the mouth of the Columbia.

5. The Pugettian Province (subfrigid). Length, about twelve hundred miles. This province has some distinctive genera, as Oregonia (related to Eurypodius), Choritia, Scyra, and Telmessus; also, 
species of Pugettia, Hyas, Pseudograpsus, Pinnothera, Fabia, Trichocera, with others of Bernhardus, Gebia, Callianassa, Nephrops, Crangon, Puracrangon, Pandalus; and among the Tetradecapoda, there are the genera Oniscus, Spheroma, Argeia, Orchestia, Allorchestes, Iphimedia, and Gammarus.

The northern part of the North American coast, including the Alaschka Archipelago, belongs to the Arctic kingdom.

\section{.B. EASTERN SECTION.}

I. TORRID SUBKINADOM.

1. The Caribbean Province (torrid), including the West India Islands, and the northern and northeastcrn coast of South America, from the north of Yucatan to beyond Bahia. Length, along the South American coast alone, about four thousand miles. There are as yet no known Caribbean genera of Podophthalmia, that do not occur in other Provinces in this or the other kingdoms. Mithrax and Uca are the more characteristic genera, and the latter is reported elsewhere only from Guáyaquil, Brazil. The following are prominent forms :-Chorinus heros, Pericera cormuta, and P. 3-spinosa, Amphitrite forceps and A. 3-spinosa, Ocypoda rhombea, Calappa marmorata, Atya occidentalis, Palinurus longimanus, Palamon Jamaicensis. The Torrid zone genus Carpilius contains two West Indian species, one of which (C. maculatus) is a cosmopolite, and allies the West Indies to the Oriental scas. Dromia, although a warm-water genus, has but a single representative, D. latior; and of Chlorodius, so common in the Orient, in like manner, only one species has been obscrved, and that occurs also in the Pacific. There is but a single species of Leucosidæ known; but the Caribbean species of Crustacea, it must be acknowlcdged, are not very thoroughly known. Through Leptopodia sagittaria the province is related to the Canaries.

2. The Floridan Province (subtorrid), Key West and a part of Florida are here embraced, together with the Bermudas. Length on the United States coast, two hundred milcs. The species are mostly those of the Caribbean Sea. A Libinia, Hyas, Epialtus, and Menippe, have been rcported from Key West and Florida, that are not mentioned as occurring about the West India Islands; also, sevcral Sesarmas, a Ranilia, and a Callianassa; these genera are none of them 
eminently Torrid zone genera. The northern species, Bernhardus pollicaris, Platyonychus ocellatus, Lupa dicantha, Panopoens limosus and Herbstii, reach as far south as Key West.

3. The Brazilian Province (subtorrid), including the harbour of Rio Janeiro, and extending north nearly to Bahia. Length, six hundred miles. The species of Crustacea are numerous, and have close relations to those of Key West. Among the species peculiar to the provinoe are the following:-Leicippa levis, Pilumnus Quoyi, Lupa spinimana, Eucrate crassimanus, Chasmagnathus granulatus, Hemigrapsus granulatus, Hepatus fasciatus, $H$. angustatus, Sicyonia carinata, etc. The number of species of Caprellids and Cymothoids is large. The following specics arc common to Rio Janciro and Key West, or the West Indies:-Acanthonyx Petiverii, Gelasimus maracoani, and $G$. vocans, Uca levis?, Xantho parvulus, Lupa dicantha, Arenceus cribraria, Ocypoda arenaria, O. rhombea, Goniograpsus ruricola, Cardisoma guanhumi, Scyllarus equinoctialis, Pencus brasiliensis, Pagurns granulatus, etc. Epialtus marginatus occurs also at the Gallapagos, and Menippe Rumphii, reported as Brazilian, belongs to the East Indies.

II. NORTH TEMPERATE SUBKINGDOM.

1. The Carolinian Province (warm temperate), extending along by Northern Florida, Georgia, and the Carolinas to Cape Hattcras. Length, six hundred miles. Several Key West species occur also in this province; for example, Libinia dubia, Mithrax hispidus, Menippe mercenarius, Arenceus cribraria, Ocypoda arenaria, Sesarma reticulata, and S. cinerea, Plagusia squamosa. Still, the general character of the species is different. Among the peculiar species mentioned by L. R. Gibbes, are Leptopodia calcarata, Pisa mutica, Cryptopodia granulata, Pilumnus aculeatus, Hepatus decorns, Guaia punctata, Porcellana macrocheles, Albunoca scutellata, Callianassa major, Gebia affinis, Alpheus heterochelis, A. formosus, and Pontonia domestica. The following northern species havc Charleston as their southern limit:-Libinia canaliculata, Cancer Sayi, Bernhardus longicarpus; Squilla empusa also reaches from Florida to Ncw York. The warm-water genera of Cancroids are all absent; the species of Hcpatus indicates a relation to the Chilian and Brazilian provinces.

2. The Virginian Province (cold temperate). It extcnds from Cape Hatteras to Capc Cod, including the shores of Virginia, New Jersey, 
Delaware Bay, New York, Connecticut, Rhode Island. Length, six hundred and fifty miles. It corresponds essentially to the Pennsylvanian Province of Milne Edwards; a name not here adopted, since the state of Pennsylvania has no part in the coasts, it being entirely inland. 'The giant Homarus, Lupa dicantha, Pilumnus Harrisii, Cancer Sayi, and C. irroratus, Libinia canaliculata, Panopoeus Herbstii, and $P$. limosus, Platyonychus ocellatus, Gelasimus vocans, Bernhardus pollicaris, and B. longicarpus, Palcomon vulgaris, with Sesarma reticulata (a southern species), occur in this province.

The province strongly contrasts with the same province across the Atlantic in the fewness of its species. Only two Maioids (exclusive of the subfrigid Hyas coarctata, and one of the two Mithrax hispidus, is properly a southern species) have been reported from these shores, with seven Cancroids, two Grapsoids (one a Pinnothera), three Anomoura (a Hippa and two Bernhardi), and three or four Macroura (besides Astaci). There is still one point of resemblance between the two regions, in that Carcinus moenas is common to both; also, the genus Homarus has a species in each, and so also the genus Cancer. But America has no Xantho north of Florida, while this genus on the other side of the Atlantic reaches to the shores of Britain. Again, we have species of Panopaei, extending even to the subfrigid region, none of which group occur in the British Seas.

3. The Nova-Scotia Province (subfrigid) extends from Cape Cod to the eastern cape of Newfoundland. Length, nine hundred miles. Cancer irroratus, Pilumnus Harrisii, Carcinus manas, and occasionally Pindalus annulicornis, Hippolyte aculeatus, Crangon vulgaris, and $C$. boreas, Lithodes maia, Hyas coarctata, Bernhardus streblonyx, occur on this coast, besides other species mentioned above as belonging to the Virginian province. We begin to find a resemblance to the Northern European and British shores.

III. SOUTH TEMPERATE SUBKINGDOM.

We know little of the Crustacea of this coast of South America. According to the temperate regions, there are four provinces. Two are north of the La Plata, and may be called the Provinces of ST. PAUL (four hundred and eighty miles long), and URAGUAY (tliree hundred and sixty miles). The mouth of the La Plata from Maldonado, around by Montevideo, Buenos Ayres, to the south Cape, C. Antonio, consti- 
tutes a third province, the Platensian; a fourth, from C. Antonio to the south cape of the bay of Rio Negro, the Nortnern Patagonian, five hundred miles long. A peculiar Grapsoid form of Rio Negro is the Cyrtograpsus angulatus. The Hemigrapsus affinis is another species, and this locality is the extreme outer limit of the genus Hemigrapsus, as far as now known. Two peculiar Idotæid forms occur in this vicinity, having been taken by us from a fish: they are Cleantis linearis, and Choetilia ovata. The genus Serolis occurs farther south, and does not appear to extend to Rio Negro.

The subfrigid region, in its southern part at least, along Fuegia, belongs properly to the Antarctic kingdom; but the rest of the coast may belong to another province, called the Southern Putagomian, which may include also the coast of Western Patagonia south of the Araucanian Province.

\section{AFRICO-EUROPEAN KINGDOM.}

The prominent differences in tempcrature between this kingdom and the Occidental have been briefly pointed out. The most influential is the existence of a large temperate-region, covering a considerable part of the Mediterranean coasts, as well as a portion of the western coast of Africa, with the Azores and Madeira; and also a subtemperate on the coast of Portugal; both of which regions are unrepresented on the coast of the United States. There are many spccies peculiar to the Mediterranean; and by their extension north, they give a greater variety to the British seas than they probably would otherwise have.

On the African coast, wc makc Cape Agulhas the southern limit. Table Bay, however, as is natural from its situation near the borders between two great kingdoms, partakes of a middlc character, yct belongs more properly to the Atlantic Ocean. It affords the Oricntal species Platyonychus trimaculatus and Dromia hirsutissima; but produces also a species of the Atlantic genus Homarus, and according to M'Leay, the Sesarma reticulata of Say, besides four other specics of this genus.

The genera pcculiar to the Africo-European kingdom, and those common.to it and the other kingdoms, are already mentioned on pages $1548,1550$. 
The following are the provinces belonging to the three subkingdoms, the torrid, the north temperate, and south temperate :-

\section{TORRID SUBKINADOM.}

1. The Guinean Province (torrid), including the coast of Guinea to $9^{\circ}$ north or Sierra Leone. Length, twelve hundred miles.

2. The Verdensian Province (north subtorrid), including the coast from $9^{\circ}$ north nearly to Cape Verde, and also the Cape Verde Islands. Length on the African coast, three hundred and fifty miles. A species of Actocodes (A. faba) occurs here, the only one of this warmwater genus yet known in the Atlantic.

3. The Biafrian Province (south subtorrid), including part of the African coast near the equator, about the Bight of Biafra, and reaching to $7^{\circ}$ or $8^{\circ}$ south; and also the islands Ascension and St. Helena. Length on the Africarn coast, nine hundred miles.

\section{NORTH TEMPERATE SUBKINGDOM.}

1. The Canarian Province (warm temperate), including the west const of Africa to the latitude of the Canaries, and embracing these islands. Length on the African coast, one thousand miles. In this province there are several species from more tropical regions, which here reach their northern limit, such as Pilumnus Forskalii, also from the Red Sea; Thalamita admete, East Indies, Natal, \&c.; Grapsus strigasus, East Indies, \&c.; Goniograpsus messor, East Indies, Red Sea, \&c. Oplophorus spinosa (= Palæmon spinosa, Brullé), Leptopodia lanceolata, Cycloes cristata, Squilla oculata, are reported only from the Canaries; though the Cycloes resembles closely a Japan species, if it be not identical with it. Many of the species of the British Channel here reach their southern limit; for example, Inachus dorhynchus, Maia squinado, Pisa tetraodon, Xantho vivulosus, Portunus corrugatus, Gonoplax angulata, Goniograpsus varius, Atelecyclus cruentatus, Dromia vulgaris, Porcellana platycheles, Gulathea strigosa; these are found also in the Mediterranean. There are besides many other Canarian species that are found in the Mediterranean, which do not extend to the north, e. g., Herbstia condyliata, Actca rufo-punctata, Eriphia spinifrons, Lupa hastata, Amplitrite hastata, Portunus holsatus, 
Calappa granulata, Dorippe lanata, Homola spinifrons, Albunsea symnista, Scyllarus latus, Arctus ursus, Gnathophyllum elegans, Paloemon Treillianus, Pagurus callidus. The cosmopolites, Plagusia squamosa and Acanthopus planissimus arc also found at the Canaries. The Leptopodia sagittaria occurs here, at the West Indics, and at Valparaiso.

2. The Mediterranean Province. The Azores and Madeira bclong to this province. The characteristic species, distinguishing it from the more northern provinces are, Lissa chiragra, Doclea ovis, Acanthonyx lunulatus, Punopoens Herbstii (also, N. American), Platyonychus nasutus, Goniograpsus maurns, Heterograpsus 6-dentatus, Brachynotus 6-dentatus, Ilia nuclea and I. rugulosa, Latreillia elegans; and at Madeira, Acanthopus planissimus and Grapsus pictus are very common species. Above we lave mentioned some of the species that are found at the Canaries also; and beyond we give a list of those found in the seas of Britain.

The relations of the Mediterranean region to Japan are mentioned by De Haan. The genera strikingly Mediterranean which occur in Japan, are Latreillia, Nilka, Caridina, Ephyra, Sicyonia, Achaus, Pandalus, Lysmata; and the species of the last three, together with Squilla mantis, are probably identical, viz., Pandalus pristis, Lysmata seticaudata, and the Achous Cranchii, which last is at least hardly distinguishable, according to De Haan, from the A. japonicus. Portunus corrugatus is also closely like a Japan species, according to De Haan. The Cycloes of the Canaries is another of the Atlantic species, allying the Atlantic region to Japan, as above mentioned. Doclea is also an Oriental genus, represented in the Occidental kingdom by Libinia. It has but one described species out of the Oricntal kingdom.

3. The Lusitanian Province (temperate), along the western coast of Portugal. Length, three hundred miles.

4. The Celitic Province (cold temperate) so named by Milne Edwards, including the Atlantic coast of Spain and France, the British Channel, and Southern Britain and Ireland. The more characteristic genera are Inachus, Hyas, Pisa, Eurynome, Perimela, Cancer (C. pagurus), Portumnus, Portunus, Polybius, Ebalia, Atelecyclus, Bernhardus, Galathea, Munida, Axius, Calocaris, Homarns, Crangon, Nika, Hyppolyte, Pandalus. Several of the species of the Celtic province, which reach to the Canaries, and occur also in the Mediterranean, are mentioned above. The following is a list of the Decapods commion to the Celtic province and the Mediterranean:- 
DECAPOdA COMMON to THE CELTIC PROVINCE AND tHe MEditerRaNEAN.*

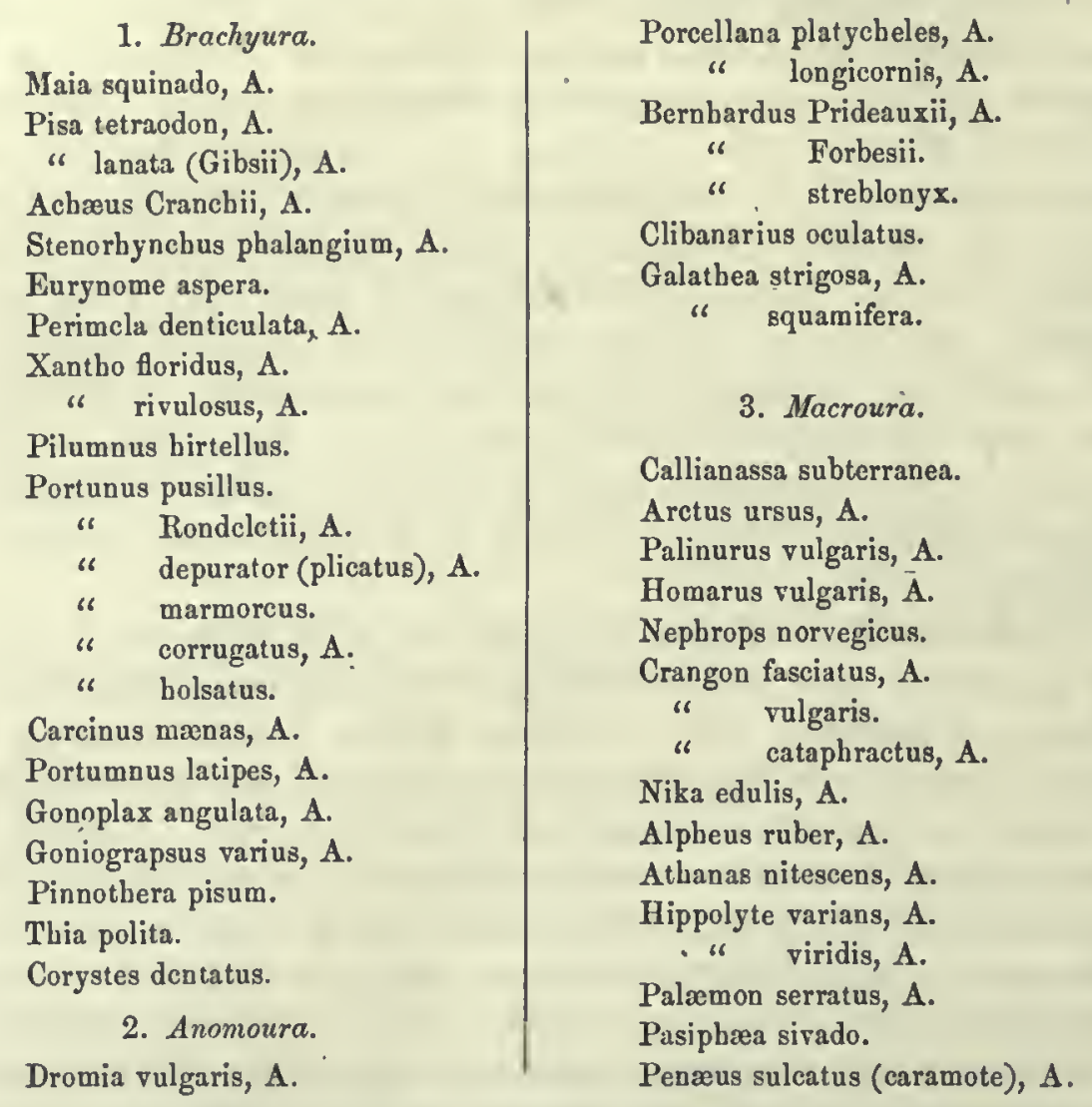

The genus Xantho, in $X$. rivulosus and $X$. floridus here reaches its extreme cold limit. Nephrops norvegicus, although more properly pertaining to the next province north, occurs also within the limits of this; and it has even been taken in the Mediterranean. Stenorhynchus phatangium and Portunus pusillus, reach south into the Mediterranean and north to the Frigid zone; Portunus holsatus, Galathea strigosa, and Porcellana platycheles, south to the Canaries and north into the subfrigid.

5. The Caledonian Province (subfrigid), including Northern Scotland, the Shetlands, Orkneys, and the Ferroe Islands. Hyas coarctatus, Portunus arcuatus, Gulathea nexa, Munida Rondeletii, Calocaris Macandrea, Nephrops norvegicus, Hippolyte spinus, Pandalus annuli-

\footnotetext{
* Those species that are reported by Lucas from Algiers, are followed by the letter A.
} 
cornis, and Pusiphoca Savignii, appear to belong especially to this province, besides some species of Bernhardus and Crangon. Lithodes maia also occurs here.

III. SOUTII TEMPERATE SUBKINODOM.

The provinces of the South Temperate zone, along the west coast of Africa, are, the Angola (warm temperate, three hundred and sixty miles long), Benguela (temperate, nine hundred miles long), and Capessian (subtemperate, four hundred and fifty miles long). Nothing is known of the Crustacea of the coasts, excepting in the last mentioned province, upon which we have already remarked. Hymenosoma orbiculare is one of the Table Bay species; and it belongs to a group that is represented only about the southern extremity of South America and in New Zealand. Palinurus Lalandii, another species, is one of the largest of known Macrourans.

South of the subtemperate region, in the cold temperate, stands in the Atlantic, the island of Tristan D'Acunha, which may be another province, the Tristensian. As mentioned by Krauss, the Spheroma tristense, Edw., is common to this island and Table Bay.

\section{ORIENTAL KINGDOM.}

Turning Cape Agulhas, we soon come into a different Zoological world. The coast immediately east to longitude $30^{\circ}$, belougs still to the Temperate zone, and must constitute a distinct province, which we call the AlgoA province (from Algoa Bay), the length of which, measured from Cape Agulhas, is full five liundred and fifty miles.

Passing beyond this, we reach the Natal province, and here we recognise at once the seas of India and the Pacific Ocean. Krauss mentions eighty-one Natal specics of Podophthalmia, not thirty of which are peculiar to this region. Twenty are found in the Indian Ocean, eighteen in the Red Sea, thirteen in Japan, eight in Australia, five in the Isle of France, besides three Europenn species, and three American. We observe further that, twenty-two of the species of Podophthalmia occur in the Pacific Islands, among which are four species supposed by Krauss to be peculiar to Natal, viz., Pagurus (Clibanarius, D.) virescens, Kr., Pagurus (Calcinus, D.) elegans, Galene 
natalensis, Kr., Platyonychus (Kraussia, D.) rugulosus, Kr., all of which occur at the Hawaiian Islands.*

Of the European species, one is the cosmopolite Gonodactylus chiragrus, Latr. The others are Alpheus Edwardsii, and Gammarus pulex, Fabr. Megalopa mutica and Hippolyte ensiferus, also reported from South Africa, do not occur at Port Natal. The American are the cosmopolites Goniograpsus pictus, and Gonodactylus chiragrus, together with Eriphia gonagra, Edw. The Sesarma reticulata, Say, and Plagusia tomentosa, Lk., also South African, are not from Port Natal.

It is obvious, therefore, that the great ocean, from the east coast of Africa to the Hawaiian and Paumotu Islands, covering two-thirds of the surface of the globe, makes one great kingdom, closely related in its species, although including several zoological provinces and subordinate districts. This fact respecting the oceans is strikingly in contrast with those relating to the continents adjoining. A list of the genera of Decapods peculiar to this kingdom, and others of the genera and species common to this and the other two kingdoms, are given on pages 1549,1550 .

This kingdom may be viewed as consisting of three SECTIONS.

First, the African, including the African coast to the head of the Red Sea and Persian Gulf, with the adjoining islands, Madagascar, Mauritius, etc.

Second, the Asiatic, from Van Diemens Land and New Holland, by the East Indies to North Japan.

Third, the Pacific, including the Pacific Islands west of New . Guinea, from New Zealand to the Hawaiian Islands. $†$

The principal provinces of these three sections are as follows:-

\section{A. AFRICAN SECTION.}

1. The Natal Province (south subtorrid), including also South Madagascar, and the Isle of France and Bourbon. This region is

* The Galene hawaiensis, D., is so closely like the $G$. natalensis, that we believe there is not sufficient reason for considering them distinct.

† The species of these three sections are separately presented in Table VI. The two columns $N$. and $S$., under East Africa, include the African species; the column $E$. Indies and Indian Ocean, and the two columns $N$. and $S$., under West Pacific, the Asiatio species; the two columns $N$. and $S$., under Middle Pacific, the PacrFio species. 
called the "Madecasse" by Edwards, a name here not accepted, as the larger part of Madagascar is in the torrid and not subtorrid region.

2. The Abrssinian Province (torrid), including the enst const of Africa and the Red Sea, excepting its northern third, and also the larger part of Madagascar and the islands of that part of the Indian Ocean.

3. The Eryturean Province (subtorrid), including the northern subtorrid part of the Red Sea, and probably also the Persian Gulf.

\section{B. ASIATIC SECTION.}

I. ASIATIO TORRID SUBKINGDOY.

1. The Indian Province (torrid), including the East Indian Islands, Northern Australia, from its most western to its most eastern cape, and the coast of Asia to latitude $121^{\circ}$ on the coast of Cochin China.

2. The LiUkid Province (subtorrid), including the islands of Liukiu and Formosa, the Meicoshimah Islands, and the southeastern coast of Niphon, along by Jeddo, with the eastern side of Kiusiu; the province has but little space on the coast of Asia, along a part of Cochin China.

A third province exists on the west coast of Australia.

II. ASIATIC NORTH TEMPERATE sUBKINGDOM.

1. The ToNQUin Province (warm temperate), including the Gulf of Tonquin and coast of China, south of $25^{\circ}$.

2. The Chusan Province (subtemperate), including the coast of China north of $25^{\circ}$ and the Yellow Sea, together with the western part of Kiusiu, along by Nagasaki.

The temperate region is nearly or quite absent from the China coast.

3. The Saghalian Province (subfrigid), including the Asiatic coast within the Japan Sea, and part of the western and the northern shores of Niphon, with the islands Saghalian, Yeso, and others.

The cold temperate region does not appear to be represented on the Asiatic coast, but.is found on the east coast of Niphon, where it forms along with the subtemperate region, what may be called the NipHoN Province. 
III. ASIATIO SOUTH TEMPERATE SUBKINGDOM.

1. The Swan Rrver Province (warm temperate), on the west coast of Australia.

2. The Fuinders Province (temperate), along the southern coast of Australia.

3. The Moneton Province (warm temperate and temperate), on the east coast of Australia.

4. The Bass Province (subtemperate), from north of Port Jackson to Van Diemens Land.

5. The Tasuanian Province (cold temperate), including Van Diemens Land.

\section{PACIFIC SECTION.}

I. PACIFIC TORRID SUBKINGDOM.

1. The Polynesian Province (torrid). To this province belong the Pacific Islands east of the East Indies, within the torrid region, including all the groups between $20^{\circ}$ south, and the Hawaiian Islands on the north, embracing also the New Hebrides and nearly all of New Caledonia. There are probably several subordinate districts, but as they are imperfectly indicated by the Crustacea, we do not attempt to lay them down. Tongatabu and Tahiti lie on the borders of the subtorrid region, in somewhat cooler waters than the Feejee or Samoan Islands.

2. The Hawaitan Province (north subtorrid), Hawaiian Islands and others in the same range, to the north of west.

3. The Raratongan Province (south subtorrid), including nearly all the Hervey Islands south of west from Tahiti, with Pitcairn's and the Gambier Islands, Ducie's, and some other islands in that vicinity.

II. PACIFIC SOUTH TEMPERATE SUBKINGDOM.

1. The Kermadec Province (warm temperate and temperate). A few islands north of New Zealand lie in this province, and probably also Norfolk Island, a little farther to the west. 
2. The Wangaroa Province (subtemperate). Includes the north part of New Zealand, of which the Bay of Islands is the prominent port.

3. The Сеathas Province (cold temperate), embracing the Chatham Islands and Middle New Zealand, nearly to its southern extremity.

In the above, the Torrid zone of the Oriental kingdom embraces in each of its regions three provinces, as follows:-
I. Torrid Region.
- African Section I.
Indian Section II.
Pacifo Section III.
II. North Subtorrid Region.
1. Abyssinian. 2. Indian.
3. Polynesian.
1. Erythrean. 2. Liukiuan.
3. Hawaiian.
III. South Subtorrid Region. 1. Natalensian. 2. West Australian. 3. Raratongan.

1. SPECIES COMMON TO THE THREE SECTIONS, THE AFRICAN, THE INDIAN, AND THE PACIFIC.

\section{Brachyura.}

Parthenope horrida.-I. Fr., Red Sea; E. I. ; Haw.

Atergatis limbatus.-R. Sea; E. I. ; Feej. Atergatis floridus.-Natal; E. I.; Tonga, Paumotus; Tahiti.

Carpilius nıaculatus.-I. Fr. ; E. I. ; Jap.; Samoa, \&e., to Paumotus.

Carpilius convexus.-R. Sea; E. I., Jap.; Feej., Haw.

Aetrea hirsutissima.-R. Sea; Samoa.

Chlorodius niger.-R. Sca (N.); E. I. ; Feej., Tonga, Samoa.

Trapezia ferruginea. - R. Sea; E. I.; Paeifie.

Cymo Andreossyi.-R. Sea; E. I. ?; Samoa, Tahiti.

Seylla serrata.-Natal ; R. Sea ; E. I., Jap.; Samoa.

Iupa sanguinolenta. - Nat.; I. Fr., R. Sea; E. I.; Haw.

Thalamita admete.-Nat.; R. Sea ; E. I. ; Samoa, Wake's, Haw.

Thalamita erenata.-Nat.; R. Sea (S.); E. I., Jap., Feej.

Clcistostoma Boseii.-Nat.; R. Sea; [E. Parribaeus antaretieus.-I. Fr.; E. I.; I. ?]; Feej.
Podophthalmus vigil.-I. Fr.; E. I., Jap.; Haw.

Ocypoda brevieornis.-I. Fr.; E. I. ; Tonga. Acanthopus planissimus. - Nat.; E. I.?; Samoa, Tahiti, Panmotu, Haw. [also Madeira].

Calappa tubereulata. - Nat. ; I. Fr., R. Sea ; E. I. ; Feej., Tonga, Haw.

Calappa fornieata.-I. Fr.; E. I.; Feej.

\section{Anomoura.}

Pagurus difformis.-I. Fr.; E. I.; Feej.

Pagurus punctulatus.-E. I. ?; E. I. ; Haw.

Caleinus tibicen. - Nat.; E. I.; Samoa, Wakc's, Tahiti, Paumotus, Haw.

Caleinus elegans.-Nat.; E. I. ?; Wake's, Paumotus, Haw.

Anieulus typieus.-I. Fr.; Jap.; Wake's, Paumotus.

Clibanarius vireseens.-Nat.; E. I.; Feej.

Cenobita rugosa.-Nat.; E. I., Jap. ; Feej.; Samoa, Tonga, Paumotus.

Birgus latro.-I. Fr.; E. I., Jap.; Samoa, Swain's, Paumotus.

\section{Macroura.} Samoa, Paumotus. 


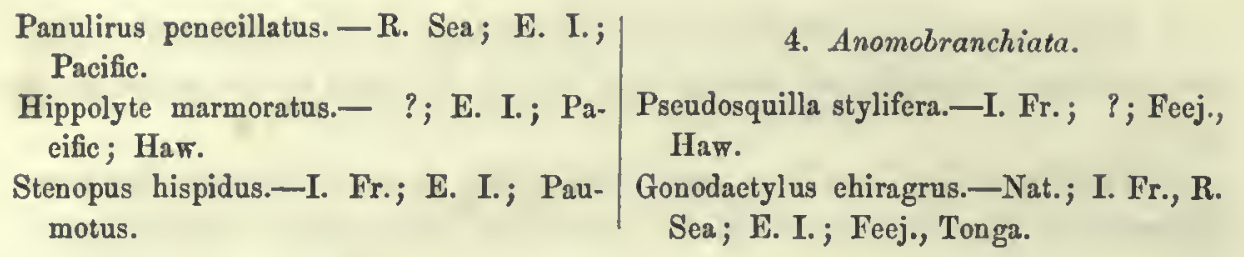

Of the above species, a few occur in both the torrid and subtorrid regions of these three sections of the Oriental kingdom, that is, in the Erythrean, Natalensian, Indian, Liukiuan, Polynesian, and Hawaiian Provinces. These are.:-Lupa sanguinotenta, Podophthalmus vigit, Calappa tuberculata, Acanthopus planissimus, Calcinus tibicen, C. elegans, and Gonodactylus chiragrus. Grapsus pictus is not included; it has not yet been reported from the eastern coast of Africa. The above list must be much increased as the species of the different regions are better understood. Some of the species have a range of over twelve thousand miles. Many species common to Natal and Japan or the Hawaiian Islands, are given in the above list. We add below a list of -

2. SPECIES COMMON TO THE NATAL AND THE LIUKIUAN (SOUTH JAPAN) OR HAWAIAN PROVINCES OF THE SUBTORRID REGIONS, AND NOT YET OBSERVED IN THE TORRID REGION INTERMEDIATE.

Micippa thalia.-Nat. and Jap.

Xantho affinis, De H.-Nat. and Jap.

Xantho obtusus, De H.-Nat. and Jap.

Carpilius petræus, De H.-Nat. (I. Fr.) and Jap.

Charybdis granulatus. - Nat. and Jap.

Thalamita prymna.-Nat. and Jap.

Gelasimus arcuatus.-Nat. and Jap.

Gelasimus lacteus, De H.-Nat. and Jap.
Ocypoda cordimana.-Nat. and Jap. Sesarma picta.-Nat. and Jap. Sesarma affinis.-Nat. and Jap. Kraussia rugulosa.-Nat. and Haw. Galene natalensis.-Nat. and Haw. Dromia hirsutissima.-S. Afr. and Haw. Calappa spinosissima.-I. Fr. and Haw. Doto sulcatus, Nat., Jap., and R. Sea.

The Natal province, includes properly two districts, the Natal and the Mauritius, the latter distinguished by its more torrid character and its larger number of East Indian species, among which are the following:-Doclea ovis, Camposcia retusa, Carpitius muculatus, Ethra scrupasa, Melia tessellata, Eriphia levimana, Calappa fornicata, Aniculus typicus, Birgus latro, Parribacus antarcticus, etc. Among the species common to the two, not also East Indian, are the following:-Elamena Mathoei (a species found also in the northern or subtorrid part of the Red Sea), Ocypoda cordimana and Orchestia Battoe. 
The following are some of the species peculiar to Port Natal :-Pisa fascicularis, Antitibinia Smithii, Acanthonyx Mac Leaii, A. scutellatus, A. 4-dentatus, Eriphia Smithii, Menippe Martensii, Pitumnus xanthoides and $P$. granulatus, Actoodes Ruppelii. Among those of the Isle of Franee or Mauritius are, Stenocionops cervicornis, Dynomene hispida, Hemigrapsus Latreilli (the genus Hemigrapsus is not yet known to oceur in the Torrid region), Atergatis sinuatifrons, A. and W., Carpilius signatus, A. and W., Dromia fallax and D. hispida, etc.; also Caprella scaura, and $C$. nodosa.

The Erytlirean province, or the subtorrid portion of the Red Sea, ineludes several species not reported from more southern parts of the sen, as Elamena Matthaci, Menoethius monoceros (a Natal species), Paramicippa platipes, Myra fugax, Rüpp., Oreophorus horridus, Rüpp., Nursia granulata, Rüpp., Macrophthalmus depressus, Rüpp.

The Abyssinian provinee in its Red Sea portion eontains seven species of Atergatis, of which A. sculptus, A. exsculptus, and A. Savignii are not elsewhere reported. Lambrus pelagicus, Actcea asper, Ruppellia tenax?, Thalamita choptalis, are other speeies, besides many that are eommon in the East Indies. Dromia unidentata is found in both the northern and southern parts.

The Indian province is eharacterized more partieularly by the following genera :-Egeria, Doclea, Micippa, Tiarinia, Menothius, Lambrus, Parthenope, Ceratocarcinus, Cryptopodia, Tlos, Atergatis, Carpitius, Actoea, Xantho, Zozymus, Panopoeus, Actoodes, Etisus, Chlorodius, Pilumnus, Eriphia, Lupa, Amphitrite, Thalamita, Charybdis, Lissocarcinus, Podophthalmus, Ocypoda, Sesarma, Xenophthalmus, Xanthasia, Calappa, Matuta, Lencosia, Ixa, Iphis, Arcania, Platyonychus, Paguristes, Pagurus, Calcinus, Clibanarius, Cenobita, Birgus, Remipes, Thalassina, Thenus, Punulirus, Atya, Alpheus, Palomon, Penceus, Acetes, Squilla, Gonodactylus, etc., and by the comparatively few species, if any, of the following Torrid zone genera, viz.-Pericera, Acanthonyx, Mithrax, Ruppellia, and Hymenocera, besides others that have been mentioned as peculiarly Occidental or Africo-European.

The relation of the Japan Seas to the Mediterranean, and also to the Natalensian have been remarked upon. The warm-water genera of Xanthidoe and Lupinos are abundantly represented in the Liukiuan provinee, so also the Calappino, Scyllarido, Sesarmino, Pulinurido, and Squillido. Eriocheir penecillatus, Curtonotus Tongimanus, Trichia 
dromiiformis, and Oncinopis arenaria arc peculiar species. The Ranina dentata occurs herc of a larger sizc than in the East Indies.

The Tonquin province is characterized by. species of Dorippe, and by Liagora rubromaculata, with some Lcucosidx. The Acanthodes armatus of De Haan from the east coast of Niphon appears to belong to the Niphon province; and the giant Macrocheira Kampferi of De Haan to the Saghalian.

The Japan Seas arc allicd to the Hawaiian through certain species, as mentioned bcyond. Through spccies of Sicyonia they are related to Rio Janeiro as well as the Meditcrranean. The species occurring both in the Japan Seas and at Port Natal, are given on page 1574.

The Swan River province on Western Australia, although of the warm temperate region, contains the following specics identical with species of the Natal province, viz., Penceus canaliculatus and Gonodactylus 3-spinosus; also the cosmopolite, Gonodactylus chiragrus, and the East India species, Thenus orientalis. The following specics found in this province, have not been mentioned from other localities, viz., Gelasimus forceps and Philyra porcellana.

The Crustacea of the castern coast of Australia have been little studied, excepting those of Port Jackson and the vicinity. This province is characterized by the presence of Halimus tumidus, D., Myctiris longicarpus, Ozius truncatus, Edw., Helocius cordiformis, $H$. inornatus, D., Chasmagnathus levis, D., and 'C. subquadratus (possibly N. Zealand), Helice crassa, Plagusia glabra, D., Paguristes frontalis (?), Callianassa (Trypoea) aistraliensis, D., Hippolyte spinicaudis.

The absence of the Xanthidx is one of the prominent characters here observed, a group of species that occur but sparingly in any subtemperate region. Among the Tetradecapods therc is the Chilian genus Amphoroidea, affording a species closcly like that of Valparaiso. The other genera of Tetradecapoda observed, are Idotoca, Spheroma, Orchestia, Allorchestes, Hyperia.

In the great Pacific section of the Oricntal kingdom, the Polynesian kingdom is of great extent, covering twenty degrees either side of the equator through the occan to $130^{\circ}$ west. Nearly the same gencra are rcpresented as in the East Indics, mentioned on page 1575. Among the exceptions, according to present knowledge, are Egeria, Doclea, Tiarinia, Purthenope, Cryptopodia, Tlos, Punopous, Lupa, Podophthalmus, Lencosia, Ixa, Arcania, Platyonychus, Thalassina, Acetes, Thenus, etc., whilc therc are present, species of Pericera, Rup- 
pellia, Cymo, Domocius, Galathea, Edipus, Harpilius, Hymenocera, Regulus. Dromia and Ranina have not been observed in the Pacific except in the Hawaiian province. No species of Penoeus has yet been reported from the Torrid region in this ocean. The Maioidea are few and small, the Xanthidae and Eriphida numerous, and often large. Some of the species common to the Pacific and East Indies have already been mentioned.*

The Hawaiian province contains the following species, not elsewhere observed:-Lahaina ovata, D., Perinea tumida, D., Huenia simplex and H. brevirostris, Xantho intonsus, D., Medoeus ornatus, Chlorodius nodosus, Pseudozius inornatus, some Trapezio, Thalamita pulchra, Lupa pubescens, Macrophthalmus telescopicus, Gelasimus minor, Ocypoda levis, D., O. Urvillii, Hemigrapsus crassimanus, Sesarma trapezium, and S. obtusifrons, Cyclograpsus granulatus, C. cinereus, Nucia speciosa, D., Albuncea speciosa, Porcellana cinctipes, Galathea spinirostris, Scyllarus latus, Randall, Nika hawaiensis, Atyoida bisulcata, Rand., Alpheus levis, A. pacificus, A. pugnax, A. diadema, Pulcemon debilis, D., P. acutifrons, D., P. grandimanus, Rand., P. gracillimanus, Rand., Penous vclutinus.

It is most closely related to the southern part of the Japan Seas, containing the following Japan species:-Penceus canaliculatus, Podophthalmus vigil, Ranina dentata, Pagurus carinatus, Rand. (=P. asper, $D e H$.$) ; and the following genera that are represented in Japan and$ not in the Torrid region, viz. :-Galene, Kraussia (D.), Nika, Scyllarus, Hemigrapsus. Several Polynesian species occur here, as Amphitrite vigilans (Feejees), Thalamita integra, Goniograpsus thuliujar (Feejees), Grapsus rudis (Ladrones), Porcellana coccinea (Paumotus), Hippolyte marmoratus (Paumotus), Calcinus tibicen, C. elegans, C. latens, Pagurus punctulatus, Chlorodius cytherea, besides Grapsus pictus, Acanthopus planissimus, and Calappa tuberculata, which have a'wide range. Lupa sanguinolenta occurs here and also in the East Indies and at the Isle

* The following oceanic Entomostraca occur in the Pacific, or East Indies, and Atlantic:-Pontella (Pontellina) turgida, Atlantic, $0^{\circ}$ to $8 \frac{1}{2}^{\circ} \mathrm{N}$., and $42^{\circ} \mathrm{S} ., 17^{\circ}$ $31^{\circ} \mathrm{W}$.; Pacific, near Hall's and Pitts' Islands, $1^{\circ}-3^{\circ} \mathrm{N} ., 173^{\circ}$ E.-Pontella (Pontellina) crispata, Atlantic, $81_{2}^{\circ} \mathrm{N} ., 23^{\circ} 45^{\prime} \mathrm{W} . ; 5^{\circ}-7^{\circ} \mathrm{N}, 1742^{\circ}-177^{\circ} \mathrm{E}$ - Undina vulgaris, Straits of Banca; Atlantic, $9^{\circ} \mathrm{S} ., 17 \frac{1}{2}^{\circ} \mathrm{W}$., and $4 \frac{1}{2}^{\circ} \mathrm{S}, 25^{\circ} \mathrm{W}$. Oithona plumifera, Atlantic, $42^{\circ}-7^{\circ} \mathrm{N}$., $20^{\circ}-22^{\circ} \mathrm{W}$; ; also $1^{\circ}$ S., $302^{\circ} \mathrm{W}$.; Pacific, near Kingsmill Islands.-Corycaeus varius, Atlantic, $1^{\circ}-7^{\circ} \mathrm{N}$., $18^{\circ}-22^{\circ} \mathrm{W}$, and $1^{\circ}-7^{\circ} \mathrm{S}$., $20^{\circ}-30^{\circ} \mathrm{W}$.; Pacific, $15 \frac{1}{2}^{\circ}$ S., $1382^{\circ}$ W.; $33^{\circ}$ S., $153 \frac{1}{2}^{\circ}$ E.; Iadrones.-Candace pachydactyla, Atlantic, $11^{\circ}$ S., $14^{\circ} \mathrm{W}$; $42^{\circ} \mathrm{S}, 2^{\circ} \mathrm{W} . ; 81^{\circ} \mathrm{S}$, $150^{\circ} \mathrm{W}$; $1^{\circ} \mathrm{S} ., 30^{\circ} \mathrm{W}$; China Sea, 300 miles northeast of Singapore. 
of France. The relations to the Natal province are similar to those with Japan, as before observed (p. 1574). Goniograpsus plicatus, a Hawaiian species, according to Krauss, is also South African.

Little is known respecting the species of the Raratongan, or Kermadec provinces.

The Wangaroa province (Northern New Zealand) is distinguished by an absencc of Cancroid forms, as in Southeastern Australia, and rather a prevalence of Grapsoid species. No Squitlidoe have yet been observed. Among the species peculiar to the province are the following:-Puramithrax Gaimardii, Eurynolambrus australis, Edw., Portunus integrifrons, $P$. cantharus, Goniograpsus strigilatus, Hemigrapsus crenulatus, H. Gaimardii, Halicarcinus varius, H.pubescens, Lomis hirta (possibly from Middle or Southern New Zealand), several Porcellana, Paguristes pilosus, Bernhardus cristatus, B. novi-zealandia, Clibanarius cruentatus, Gebia hirtifrons, Paranephrops planifrons, P. tenuicornis, B. oxquimanus, Alope palpalis, Hippolyte spinifrons, Palomon affinis, with species of the Tetradecapodan genera, Idotoca, Armadillo, Spherillo, Oniscus, Scyphax, D., Iygia, Cymothoa, Nerocila, Aga, Spheroma (several species), Orchestia, Allorchestes, Iphimedia, Melita, OEdicerus, Hyperia.

The genus Hymenicus, which is near Hymenosoma, and the Plagusia tomentosa found also at Table Bay, show a relation to the Capensian province (South Africa). Palamon Quoyanus is also stated by Krauss to be a South African species, found at Port Natal.

The genera Ozius, Hemigrapsus, and Chasmagnathus, and some of their species, are common to the Bass province (Australia) and North Ncw Zealand, showing a relation between the two. Yet the difference in species is still so great, that they are properly distinct provinces. New Zealand is over twelve hundred miles from New Holland, and its Crustacea are hardly as much like those of New Holland as those of Valparaiso. The following genera characterize both Chili and North New Zealand:-Cancer, Ozius, Cyclograpsus, Paguristes, and Betous; and the Cancer Edwardsii and Plagusia tomentosa appear to be common to the two provinces, while the genus Cancer is not elsewhere known out of America and Northern Europe. Palcomon affinis of the Bay of Islands, as 'Edwards observes, is liardly distinguishable from $P$. squilla of the coasts of France and Britain. The species of Portunus in these southern seas are representatives of the most characteristic of European genera, and thcy belong rather to the 
cold temperate than subtemperate regions of the Australian and New Zealand Seas. Portunus integrifrons is reported from Tasmania (Van Diemens Land). Ozius represents Xantho of the British Channel.

\section{ARCTIC AND ANTARCTIC KINGDOMS.}

With our existing knowledge of species, the Arctic and Antarctic kingdoms widely differ; but much of this difference may be owing to the greater extent of land in the northern kingdom, and not a little to our limited knowledge of the latter. In the Arctic Frigid zone, there are the following genera of Podophthalmia:- Hyas 1 species, Stenorhynchus 1, Cancer 1, Portunus 1, Carcinus 1, Lithodes 2, Bernhardus 3, Galathóa 2, Crangon 2, Sabinea 1, Argis 1, Hippolyte 18, Pandalus 3, Palaemon 1, Thysanopoda 3, Mysis 3, Myto 1. Out of these, only Lithodes and Galathea are at present known to occur in the Antarctic kingdom, and as yet we are not certain that either reaches beyond Fuegia, near the limits of the subfrigid and frigid regions: further researches are required. The Thysanopoda of the north are represented in the south by a species of Euphausia.

Among the Tetradecapoda, the following exist in the Arctic kingdom :-IIot aideA, Idotrea, 9 species, Glyptonotus 1; Oniscoiden, Iygia, 1, Jora 2, Joeridina 1, Asellus 1, Janira 1, Henopomus 1, Munna 1; of Crmotiloidea, Ega 3 ; Serolidea, Praniza 1, Anceus 1; Tanaidea, Tanais 6, Crossurus 1, Bopyrus 1, Phryxus 2, Dajus 1; of CAPRELLidea, Proto 2, Caprella 6, Agina 2, Cercops 1, Podalirius 1; GammaRIDEA, Dulichia 1, Siphonocetes 1, Unciola 1, Laphystius 1, Orchestia 2, Stegocephalus 1, Anonyx 2, Leucothoe 2, Acanthonotus 3, Iphimedia 14, Edicerus 1, Gammarus 13, Photis 1, Melita 2, Pardalisca 1, Ischyrocerus 2, Microcheles 1, Lepidactylis 1, Pontiporeia 1, Ampelisca 1, Protomedeia 1, Phoxus 1; HyPeridea, Lestrigonus 1, Hyperia 1, Metoceus 1, Themisto 2.

From the Antarctic kingdom, there are at present known, Glyptonotus 1, Idotoca 1, Cirolana 1, Serolis 1, Uiistes (related to Anonyx) 1; of Hyperidea, Cyllopus 1, Tauria 1, Themisto 1; and if we add Southern Fuegia, Eurypodii 2 or 3, Halicarcinus 1, Munida 1, Grimothea 1, Lithodes 3, Tylus 1, Oniscus 1, Styloniscus 1, Jora 1, Pterelas 1, Spheroma 3, Serolis 3, Anonyx 1, Amphithoe 1, Gammarus 1, etc. The contrast is again very striking. Serolis and some allied forms, with Glyptonotus are the most characteristic of southern Isopoda, and the 
first of these genera is not known in the north. Halicarcinus characterizes the south but not the north. Hippolyte and Crangon are common in the north, and have not yet been detected in the south. Lithodes is common to both. Eurypodius is wholly southern, but has its analogue in Oregonia of Northwest America. If then we were to characterize the kingdoms by any of the species, we should call the Arctic, the Hippolyte kingdom, about half of the known species of the genus Hippolyte being Arctic; and the southern, the Serolis kingdom. The names imply a higher zoological rank for the Arctic than the Antarctic Seas.

The Arctic kingdom is naturally divided into three provinces. One occupying the North Atlantic Ocean; one corresponding, north of the Pacific; and the third, a Polar province. The limits of the Polar province we cannot exactly lay down. But the more Frigid seas which afford only Tetradecapods (and perhaps a species or so of Decapods) should be considered as constituting a distinct province from that in which species of Hippolyte and Crangon are common. These provinces are the Norwegian, the Camtschatican, and the North Polar.

The Norwegian includes the coast of Norway and Iceland, with a part probably of Greenland; characterized by Lithodes maia, Hyas araneus, Bernhardus pubescens, Galathea rugosa, Crangon lar, C. 7-carinatus, and many species of Hippolyte, etc. The Camtschatican comprises Kamtschatka, the Aleutian Islands, and the neighbouring part of the North American coast, and extending it may be some distance beyond Behring's Straits, and is characterized by the Lithodes camschatica, Telmessus chirogonus, Bernhardus splendescens, Crangon salebrosus, Hippolyte armata, H. cornuta.

In these Polar seas, the species have often a wide range, and probably pass from one ocean to the other through the Polar oceans. Thus Crangon boreas, Carcinas monas, Pagurus streblonyx, Hippolyte aculeatus, are not only found on opposite sides of the Atlantic, but also in the North Pacific.

The Antarctic kingdom nay also consist of three provinces :-

1. The Fuegian Province, including Fuegia, the Falklands, South Georgia; and characterized by Lithodes antarctica, $L$. verrucosa, $L$. granulata, species of Eurypodius, * Halicarcinus, Galathea, Spheroma, and Serolis.

* The species of Eurypodius probably belong more especially to the South Patagonian or the Araucanian province, although occurring also in the Fuegian. 
2. The Aucklandian Province, embracing the Aucklands and perhaps the south extremity of New Zealand.

3. The South Polar province, including the South Shetlands (whence comes the huge Glyptonotus of Eights), and also the Antarctic lands of Wilkes and Ross.

The group Hymenicinæ, including the genera Hymenosoma, Halicarcinus, and Hymenicus, is peculiarly a southern type, and through these genera the extremities of the continents have a common character. The first characterizes the Cape of Good Hope, the second Patagonia and Fuegia, and the third New Zealand. The Patagonian genus reaches north to Valparaiso, into the same temperature region (the subtemperate) that affords the Hymenosoma of South Africa and Hymenicus of New Zealand, and this subtemperate region is the highest northern limit of the group. Halicarcinus is developed in its greatest perfection in Fuegia.

\section{ORIGIN OF THE GEOGRAPHICAL DISTRIBUTION OF CRUSTACEA.}

The origin of the existing distribution of species in this department of zoology deserves attentive consideration. Two great causes are admitted by all, and the important question is, how far the influence of each has extended. The first, is original local creations; the second, migration.

Under the first head, we may refer much that we have already said on the influence of temperature, and the restriction of species to particular temperature regions. It is not-doubted that the species have been created in regions for which they are especially fitted; that their fitness for these regions involves an adaptation of structure thereto, and upon this adaptation, their characteristics as species depend. These characteristics are of no climatal origin. They are the impress of the Creator's hand, when the species had their first existence in those regions calculated to respond to their necessities.

The following questions come up under this general head:-

1. Have there been local centres of creation, from which groups of 'species have gone forth by migration?

2. Have genera only and not species, or have species, been repeated by creation in distinct and distant regions?

3. How closely may we recognise in climatal and other physical 
conditions, the predisposing cause of the existence of specific genera or species?

With regard to the second head, migration, we should remember, that Crustacea are almost wholly maritime or marine; that marine waters are continuous the globe around; and that no seashore species in zoology are better fitted than crabs for migration. They may cling to any floating $\log$ and range the seas wherever the currents drift the rude craft, while the fish of the sea-shores will only wander over their accustomed haunts. Hence it is, that among the Pacific Islands the fishes are often to a considerable extent peculiar to particular groups of islands, while the Crustacea are much more generally diffused.

A direction and also a limit to this migration exist, $(1)$ in the currents of the ocean, and (2) in the temperature of its different regions. Through the Torrid zone, the currents flow maiuly from the east towards the west; yet they are reversed in some parts during a certain portion of the year. But this reversed current in the Pacific never reaches the American continent, and hence it could never promote migration to its shores. Again, beyond $30^{\circ}$ or $35^{\circ}$ of north or south latitude, the general course of the waters is from the west, and the currents are nearly uniform and constant. Here is a means of eastward migration in the middle and higher temperate regions. But the temperature regions in these latitudes are more numerous than in the tropics, and species might readily be wafted to uncongenial climates, which would be their destruction; in fact they could hardly escape this. Moreover, such seas are more boisterous than those nearer the equator. Again, these waters are almost entirely bare for very long distances, and not dotted closely with islands like the equatorial Pacific.

In the northern hemisphere, on the eastern coasts especially, there are warm currents from the south and cold currents from the north. The former overlie the latter to a great extent in the summer and may aid southern species in northward migrations. Cape Hatteras is nearly the termination of the summer line of $70^{\circ}$ (see Maury's Chart), a temperature which belongs to the subtorrid region in winter. On the China coast, at Macao there is a temperature of $83^{\circ}$ in July, and in the Yellow Sea, of $78^{\circ}$ to $80^{\circ}$. But such northward migrations as are thus favoured, are only for the season; the cold currents of the winter months destroy all such adventurers, except the individuals of 
some hardier species that bclong to the scas or have a wide range in distribution. Sea-shorc Crustacea are not in themsclves migratory, and are thus unlike many species of fish. Even the swimming Portunidre are not known voluntarily to change their latitudes with the season.

The following is a brief rccapitulation of the morc prominent facts bearing on these points.

1. The distribution of individuals of many species through twelve thousand miles in the. Torrid zone of the Oriental seas.

2. The very sparing distribution of Oriental spccics in Occidental seas.

3. The almost total absence of Oriental species from the west coast of America.

4. The world-wide distribution within certain latitudes of the species we have called cosmopolites.

5. The occurrence of closely allied genera at the Hawaiian Islands and in the Japan seas.

6. The occurrence of the same subtorrid species at the Hawaiian Islands and at Port Natal, South Africa, and not in the Torrid zone intermediate, as Kraussia rugulosa and Galene natalensis.

7. The occurrence of identical species in the Japan seas and at Port Natal.

8. The occurrence of the same species (Plagusia tomentosa) in South Africa, New Zealand, and Valparaiso; and the occurrence of a second species (Canccr Edwardsii (?)) at New Zealand and Valparaiso.

9. The occurrence of closely allied species (as 'species of Amphoroidea and Ozius) in New South Wales and Chili.

10. The occurrence of the same species in the Japan seas and the Mediterranean, and of several identical genera.

11. The occurrence of a large number of identical species in the British seas and the Mediterranean; and also in these seas and about the Canary Islands.

12. The occurrence of closely allied, if not identical, species (as of Palæmon) in New Zealand and the British seas; and also of certain genera that are elsewhere peculiarly British, or common only to Britain and America.

13. An identity in certain species of Eastern and Western America. 
The following are the conclusions to which we are led by the facts:

I. The migration of species from island to island through the tropical Pacific and East Indies may be a possibility; and the same species may thus reach even to Port Natal in South Africa. The currents of the oceans favour it, the temperature of the waters is congenial through all this range, and the habits of many Crustacea, although they are not voluntarily migratory, seem to admit of it. The species which actually have so wide a range are not Maioids (which are to a considerable extent deep-water species), but those of the shores; and some, as Thalamita admete, are swimming species.

II. The fact, that very few of the Oriental species occur in the Occidental seas, may be explained on the same ground, by the barrier which the cold waters of Cape Horn and the South Atlantic present to the passage of tropical species around the Cape westward, or to their migration along the coasts.

Moreover, the diffusion of Pacific tropical species to the Western American const is prevented, as already observed, by the westward direction of the tropical currents, and the cold waters that bathe the greater part of this coast.

III. When we compare the seas of Southern Japan and Port Natal and find species common to the two that are not now existing in the Indian Ocean or East Indies, we hesitate as to migration being a sufficient cause of the distribution. It may, however, be said that driftings of such species westward through the Indian Ocean may have occasionally taken place; but that only those individuals that were carried during the season quite through to the subtorrid region of the South Indian Ocean (Port Natal, etc.), survived and reproduced, the others, if continuing to live, soon running out under the excessive heat of the intermediatc equatorial regions. That they would thus run out in many instances is beyond question; but whether this view will actually account for the resemblance in species pointed out is open to doubt.

IV. When further, we find an identity of species between the Hawaiian Islands and Port Natal-half the circumference of the globe, or twelve thousand miles, apart-and the species, as Galene natalensis, not a species found in any part of the torrid region, and represented by another species only in Japan, we may well question whether we can meet the difficulty by appealing to inigration. It may however be said, that we are not as yet thoroughly acquainted 
with the species of the tropics, and that facts may hereafter be discovered that will favour this view. The identical species are of so peculiar a character that we deem this improbable.

V. The existence of the Plagusia tomentosa at the southern extremity of Africa, in New Zealand, and on the Chilian coasts, may perhaps be due to migration, and especially as it is a southern species, and each of these localities is within the subtemperate region. We are not ready however to assert, that such journeys as this range of migration implies are possible. The oceanic currents of this region are in the right direction to carry the species eastward, except that there is no passage into this western current from Cape Horn, through the Lagulhas current, which flows the other way. It appears to be rather a violent assumption that an individual or more of this species could reach the western current from the coast on which it might have lived; or could have survived the boisterous passage, and finally have had a safe landing on the foreign shore. The distance from New Zealand to South America is five thousand miles, and there is at present not an island between.

VI. Part of the difficulty in the way of a transfer of species between distant meridians night be overcome, if we could assume that the intermediate seas had been occupied by land or islands during any part of the recent epoch. In the case just alluded to, it is possible that such a chain of interrupted communication once had place; and this bare possibility weakens the force of the argument used above against migration. Yet as it is wholly an assumption, we cannot rely upon it for evidence that migration has actually taken place.

VII. The existence of the same species on the east and west coasts of America, affords another problem, which migration cannot meet, without sinking the isthmus of Darien or Central America, to afford a passage across. As yet we know of no evidence that this portion of the continent has been beneath the ocean during the recent epoch. An argument against such a supposition might be drawn from the very small number of species that are identical on the two sides, and the character of these species. Libinia spinosa occurs at Brazil and Chili, and has not been found in the West Indies. Leptopodia sagittaria, another Maioid, occurs at Valparaiso, the West Indies, and the Canaries.

VIII. The large number of similar species common to the Mediterranean and British seas may be due to migration, as there is a con- 
tinuous line of coast and no intermediate temperature rendering such a transfer impossible; and the passage farther south to the Canaries of several of the species is not beyond what this cause might accomplish. Still, it cannot be asserted that in all instances the distribution here is owing to migration; nor will it be admitted unless other facts throw the weight of probability on that side.

IX. But when we find the same Temperate zone species occurring in distant provinces, these provinces having between them no water communication except through the Torrid or Frigid zone, and offering no ground for the supposition that such a communication has existed during the recent epoch, we are led to deny the agency of voluntary or involuntary migration in producing this dissemination. An example of this, beyond all dispute, is that of the Mediterranean Sea and Japan. No water communication for the passage of species can be imagined. An opening into the Red Sea is the only possible point of intercommunication between the two kingdoms; but this opens into the Torrid zone, in no part of which are the species found. The two regions have their peculiarities and their striking resemblances; and we are forced to attribute them to original creation and not intercommunication.

$X$. The resemblances found are not merely in the existence of a few identical species. There are genera common to the two seas that occur nowhere else in the Oriental kingdom, as Latreillia, Ephyra, Sicyonia, \&c.; and species where not identical have an exceedingly close resemblance.

Now this resemblance in genera and species (without exact identity in the latter) is not explained by supposing a possible intercommunication. But we may reasonably account for it on the ground of a similarity in the temperature and other physical conditions of the seas; and the well-known principle of "like causes, like effects" forces itself upon the mind as fully meeting the case. Mere intercommunication could not produce the resemblance; for just this similarity of physical condition would still be necessary. And where such a similarity exists, creative power may multiply analogous species; we should almost say, must, for, as species are made for the circumstances in which they are to live, identical circumstances will necessarily imply identity of genera in a given class, and even of specific structure or of subgenera.

If, then, the similarity in the characters of these regions is the 
occasion of the identity of genera, and of the very close likencss in certain species (so close that an identity is sometimes strongly suspected where not admitted), we must conclude that there is a possibility of actual identity of species, through original creation. This, in fact, becomes the only admissible view, and the actually identical species between Japan and the Mediterranean are examples.

$\mathrm{XI}$. When we find a like resemblance of genera and specics between Temperate zone provinces in opposite hemispheres that are almost exact antipodes, as in the case of Great Britain aud New Zealand, we have no choice of hypotheses left. We must appcal directly to creative agency for the peopling of the New Zealand seas as well as the British, and see in both, like wisdom, and a like adaptedness of life to physical nature. The Palæmon affinis of the New Zealand seas is hardly distinguishable from the common P. squilla of Europe, and is one example of this resemblance. It may not be an identity; and on this account it is a still better proof of our principle, because there is no occasion to suspect migration or any other kind of transfer. It is a creation of species in these distant provinces, which are almost identical, owing to the physical resemblances of the seas; and it shows at least, that a very close approximation to identity may be consistent with Divine Wisdom.

The resemblance of the New Zealand and British seas has been remarked upon as extending also to the occurrence in both of the genera Portunus and Cancer. It is ccrtainly a wonderful fact that New Zealand should have a closer resemblance in its Crustacea to Great Britain, its antipode, than to any other part of the world-a resemblance running parallel, as we cannot fail to observe, with its geographical form, its insular position, and its situation among the temperate regions of the ocean. Under such circumstances, there must be many other more intimate resemblances, among which we may yet distinguish the special cause which led to the planting of peculiar British forms in this antipodal land.

The close resemblance in species and genera from Britain and New Zealand, and from Japan and the Mediterranean, and the actual identity in some spccies among the latter, proves therefore that, as regards the species of two distant regions, identity as well as resemblance may be attributable to independent creations, these resemblances being in direct accordance with the physical resemblances of the regions. As this conclusion cannot be avoided, we are compelled in all cases to try 
the hypothesis of migration by considering something beside the mere possibility of its having taken place under certain assumed conditions. The possibility of independent creations is as important a considcration. After all the means of communication between distant provinces have been devised or suggested, the principle still comes up, that it is in accordance with Divine Wisdom, to creatc similar and identical species in different regions, where the physical circumstances are alike; and we must determine by special and thorough investigation, whether one or the other cause was the actual origin of the distribution in each particular case. Thus it must be with reference to the wide distribution of species in the Oriental tropics, as well as in the European temperate regions, and the Temperate zone of the South Pacific and Indian Oceans.

XII. With respect to the creation of identical species in distant regions, we would again point to its direct dependence on a near identity of physical condition. Although we cannot admit that circumstances or physical forces have ever created a species (as like can only beget like, and physical force must result simply in physical force), and while we see in all nature the free act of the Divine Being, we may still believe the connexion between the calling into existence of a species and the physical circumstances surrounding it to be as intimate nearly as cause and effect. The Creator has in infinite skill, adapted each species to its place, and the whole into a system of admirable harmony and perfection. In his wisdom, any difference of physical condition and kind of food at hand, is sufficient to require some modification of the intimate structure of species, and this difference is expressed in the form of the body or members, so as to produce an exactness of adaptation, which we are far from fully perceiving or comprehending with our present knowledge of the relations of species to their habitats.

When therefore we find the same species in regions of unlike physical character, as, for example, in the seas of the Canaries and Great Britain-regions physically so unlike-we have strong reason for attributing the diffusion of the species to migration. The difference between the Mcditerranean and Great Britain may require the same conclusion for the species common to these seas. They are so far different, that we may doubt whether species created independently in the two could have been identical, or even have had that resemblance that exists between varietics; for this resemblance is usually of the 
most trivial kind, and effects only the least essential of the parts of a species.

The continental species of Crustacea from the interior of different continents, are not in any case known to be identical; and it is well understood that the zoological provinces and districts of the land are of far more limited extent than those of the ocean. The physical differences of the former are far more striking than those of the latter. As we have observed elsewhere, the varietics of climate are greater; the elevation above the sea may vary widely; and numbcrless are the diversities of soil and its conditions, and the circumstances above and within it. Hence as the creation of each specics has reference most intimately to each and all of these conditions, as well as to other prospective ends, an identity between distant regions is seldom to be found, and the characteristic groups of genera are very widely diverse. Comparatively few genera of Insects have as wide a range as those of Crustacea; and species with rare exceptions, have very narrow limits. Where the range of a species in this class is great, we should in general look to migration as the cause rather than original creation; but the considerations bearing on both should be attentively studied before either is admitted as the true explanation.

Throughout the warmer tropical oceans, a resemblance in the physical conditions of distant provinces is far more common and more exact than in the Temperate zone. And hence it would secm that we could not safely appeal to actual differences as an argument against the creation of a species in more than one place. The species spread over the Oriental Torrid zone may hence be supposed to owe their distribution to independent creations of the same specics in different places, as well as to migration. Yet we may in this underrate the exactness of physical ideutity required for independent creations of the same species. We know that for some chcmical compounds, the condition of physical forces for their formation is exceedingly delicate; and much more should we infer that when the creation of a living germ was concerned, a close exactness in the conditions would be required in order that the creation should be repeated in another place. Infinite power, it is true, may create in any place; but the creation will have reference to the forces of matter, the material employed in the creation. The few species common to the Oriental and Occidental torrid seas scem to be evidence on this point; the fact that the Oriental species have so rarely been repeated in the Occidental 
seas, when the conditions seem to be the same, favours the view that migration has been the main source of the diffusion in the Oriental tropics.

As we descend in the order of Invertebrates, the species are less detailed in structure, with fewer specific parts and greater simplicity of functions, and they therefore admit of a wider range of physical condition; the same argument against multiplication by independent creations in regions for the most part different, does not, therefore, so strongly hold. As we pass, on the contrary, to the highest groups in Zoology, the argument receives far greater weight; and at the same time there are capabilities of migration increasing generally in direct ratio as we ascend, which are calculated to promote the diffusion of species, and remove the necessity of independent creations.

Migration cannot therefore be set aside. It is an actual fact in nature, interfering much with the simplicity which zoological life in its diffusion would otherwise present to us. Where it ends, and where independent creations have taken place, is the great problem for our study. This question has its bearings on all departments of Zoology; but in few has migration had the same extended influence as in that of Crustacea. Molluscs, if we except oceanic species, are no travellers, and keep mostly to narrow limits.

XIII. There is evidence in the exceedingly small number of Torrid zone species identical in the Atlantic and Indian Oceans, that there has been no water communication across from one to the other in the Torrid zone, during the period since existing species of Crustacea were first on the globe.

XIV. As to zoological centres of diffusion for groups of species, we can point out none. Each species of Crustacea may have had its place of origin and single centre of diffusion in many and perhaps the majority of cases. But we have no reason to say that certain regions were without life, and were peopled by migration from specific centres specially selected for this end. If such centres had an existence, there is at present no means by which they may be ascertained. The particular temperature region in which a species originated may be ascertained by abserving which is most favourable to its development: we should thus conclude that the Ranina dentata, for example, was created in the subtorrid region and not the torrid, as it attains its largest size in the latter. By pursuing this course with reference to each species, we may find some that are especially fitted for almost. 
every different locality. Hence, we might show, as far as reason and observation ean do it, that all regions have had their own special creations.

The world throughout all its epoehs in past history, has been furnished with life in accordanee with the times and seasons, each species being adapted to its age, its place, and its fellow speeies of life.

In the elaboration of the tablcs given in the preeding ehapter, the following works and memoirs have been eonsulted:-

A. G. Desmarest's Considérations Générales sur les Crustacés, 8ro., Paris, 1825.

Milne Edwards's Histoire Naturclle des Crustacés, 3 vols., 8vo., Paris, 1834-1840.

MrLne Edwards, in Victor Jacquemont's Voy. dans L'Inde, 4 to., 1844 ; and other papers in the Archives du Mus. d'Hist. Nat., and the Annales des Sci. Naturelles.

Mrine Edwards and H. Lucas, on the Crustacea of D'Orbigny's Voy. dans L'Amérique Méridionale, 4to., Paris, 1843.

W. E. Leacr's Malacostraca Podophthalmata Britannix, 4to., 1815-1817.

Savigny, Crustacea of Napoleon's Egypt, folio.

De HaAN's Crustacea of the Fauna Japonica, fol., 1833-1850.

M'Lray, in Smith's Illustrations of the Zoology of South Africa, 1838.

E. RüPpeLL's Beschreibung und Abbildung ron 24 Arten kurzschwänzigen Krabben als Beitrag zur Naturgeschichte des rothen Mecres, 4to., Frankfurt, 1830.

Trros. BeLL's papers on the genus Cancer and on some Crustacea of the coasts of South America, Zool. Trans., i. 335, and ii. 39.

Thos. Bell's British Crustacea, Parts 1 to 6, 8vo., Iundon, 1844-1847.

R. Owen, on the Crustacea of the Voyagc of the Blossom; and also, Appendix to Sir John Ross's Second Voyage in search of a Northwest Passage.

H. Rathke, Fauna der Krym, Mem. Imp. Acad. Sci. St. Petcrsburg, iii. 1837, aud

Beit. zur Fauna Norwegens Kais. Lcop. Car. Acad. der Nat. Bonn., vol. xx., 4to., 1840.

Dr. F. Krauss's Südafrikanischen Crustaceen, 4to., Stuttgart, 1843.

O. S. Costa's Fauna del Reguo di Napoli, 4to., Crostacei in 1836.

WeBB and Bertherot, on the Canaries.

KröyrR's Conspectus Crustaccorum Greenlandix, Copenhagen, and also various papers in his Tidskrift, published at Copenhagen; and also the Crustacea of the Spitzbergen Expedition, in folio.

Nrcolet, in Gay's Historia de Chile, Zoologia, Tome III. (including the Crustacca), 1849.

H. Lucas, Crustacea of Expl. de l'Algiers, 4to., Paris.

List of the Specimens of Crustacca in the Collection of the British Muscum, 16mo., London, 1847.

List of the Specimens of British Crustacea in the British Museum, 161uo., London, 1850. 
A. Adams and A. White, Crustacea of the Voyage of the Samarang, 4to., London, 1848.

A. A. GoutD's Invertebrata of Massachusetts, 374 pp., 8vo., with plates. Boston, 1841. LEwis R. GiBBes, on the Carcinological collections of the Cabinets of Natural History in the United States, with an cnumcration of the species contained thercin, and Descriptions of New Species. From Proceedings of the Amer. Assoc., vol. iii., 1850.

W. BAIRD's Natural History of British Eutomostraca, 8ro., London, 1850.

Eydoux and Souleyet, Voyage of the Bonite.

Hombron and Jacouinot, Voy. au Pole Sud. et dans l'Oceanie.

Besides various other Memoirs by Say, J. W. Randall, Pöppig, Erichson, Philippi, Muiller, Wiegmann, Guèrin, S. Loven, H. D. S. Goodsir, A. White, W. Thompson, ete, in the Journal Acad. Nat. Sci. Philadelphia; Wiegmann's Archiv. f. Naturg., Berlin; Guérin's Magasin de Zool., Paris, and also Revue Zoologique, Paris; Annales des Sei. Nat., Paris; Vet. Acad. Förhandl., Stockholm; Annals and Mag. Nat. Hist., London; Reports of Brit. Assoc.; Procecdings of the Zool. Soc., London; Jameson's New Edinburgh Journal, etc., etc. 



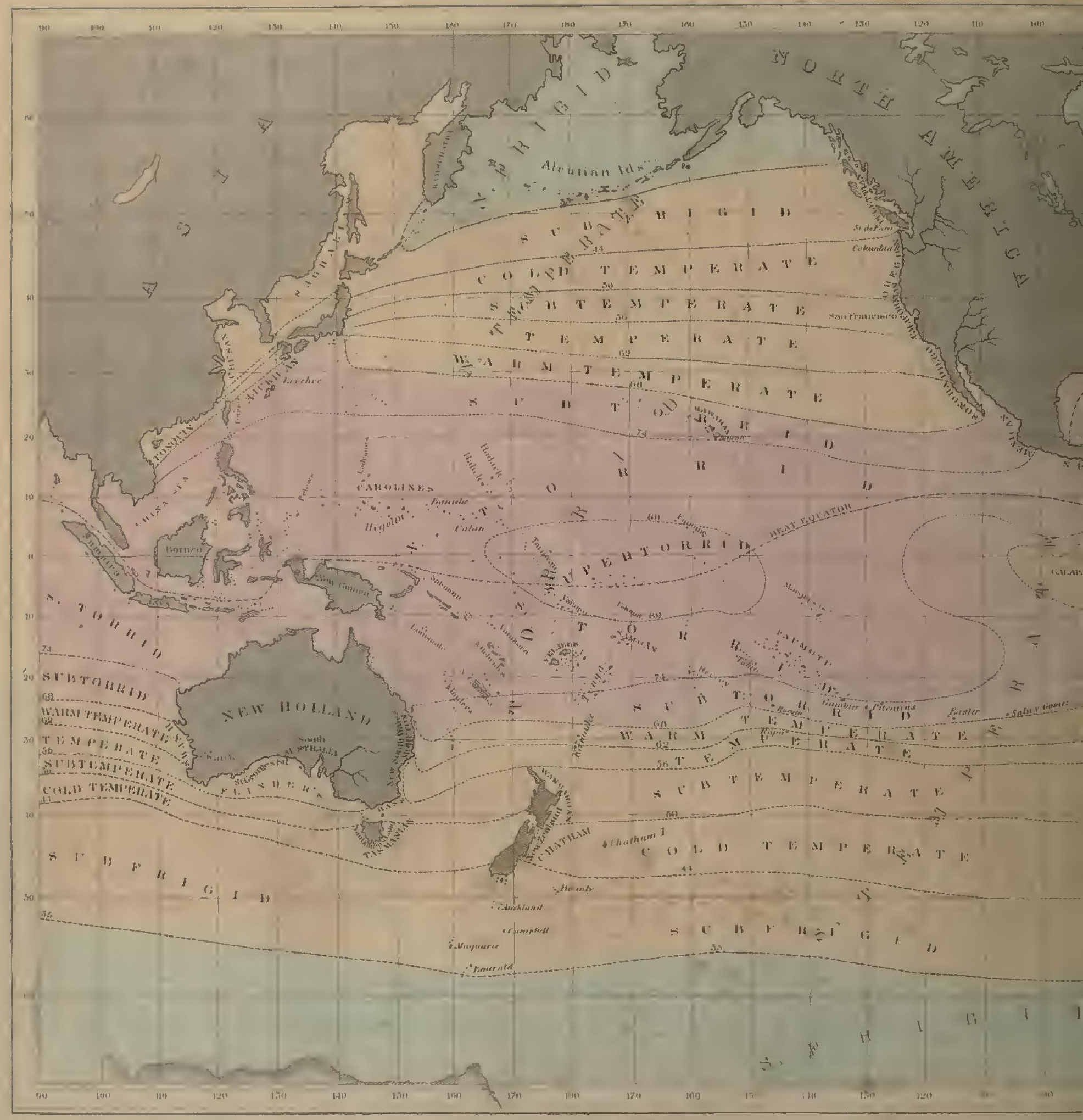




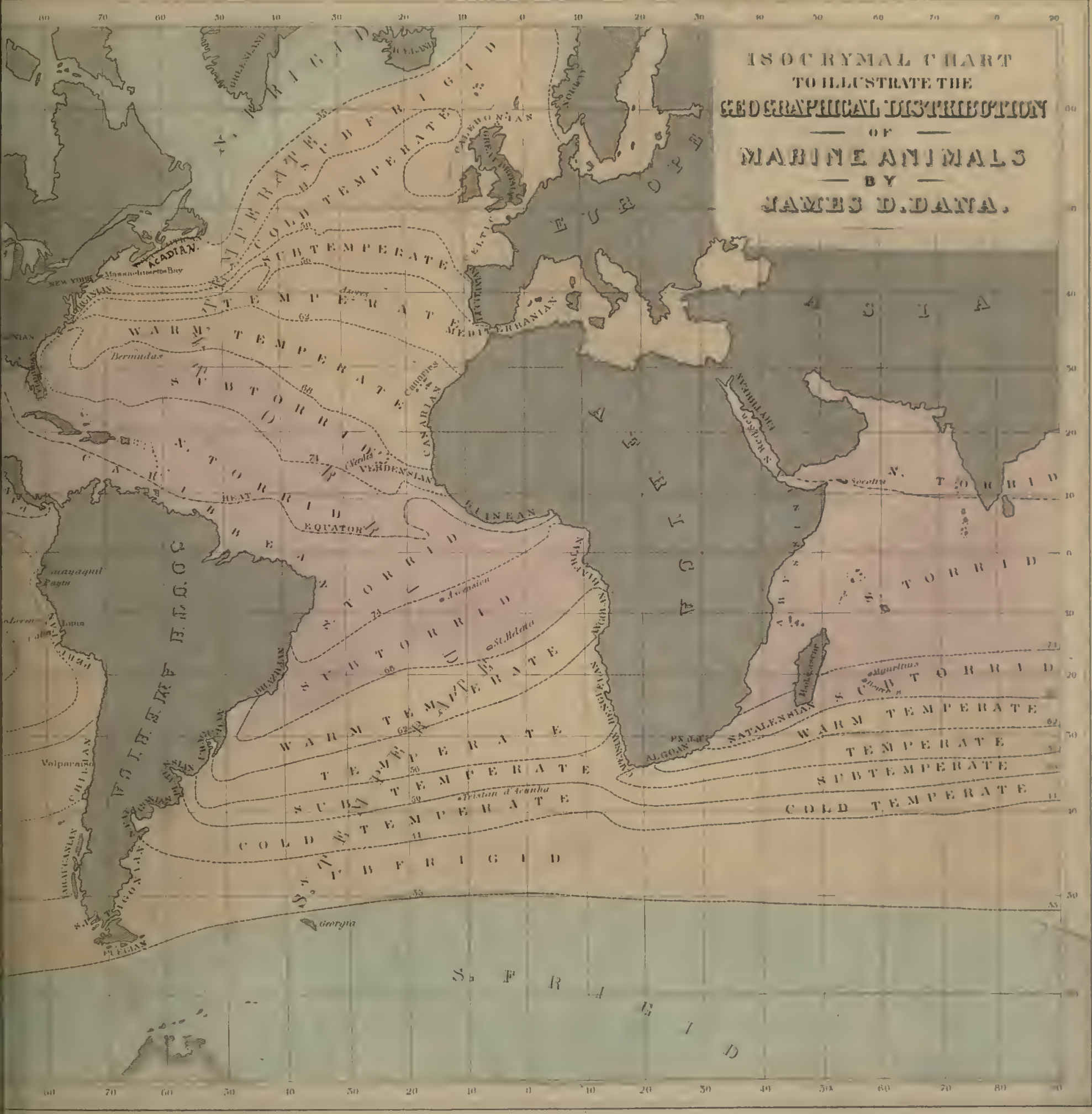









PLEASE DO NOT REMOVE CARDS OR SLIPS FROM THIS POCKET

UNIVERSITY OF TORONTO UIBRARY

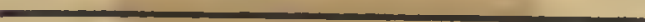

\section{Zool} Insecta D Dana, James $D$. On the classification and geographical distribution of crustacea

Biolngical

a Medical 
